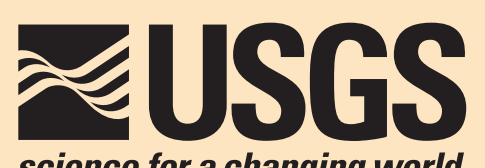

\title{
Stratigraphy and Depositional Environments of the Upper Pleistocene Chemehuevi Formation Along the Lower Colorado River
}

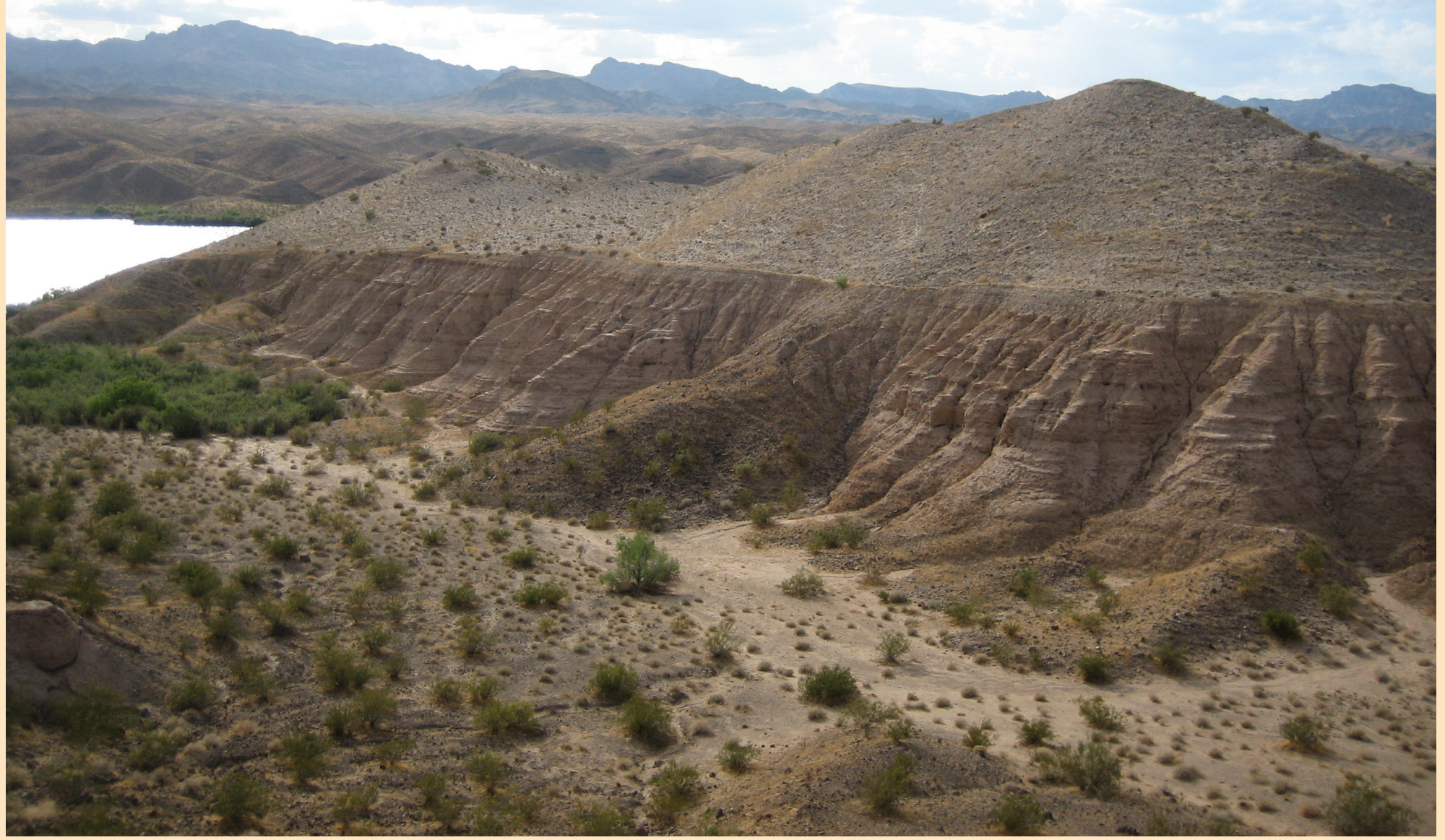

Professional Paper 1786

U.S. Department of the Interior U.S. Geological Survey 
This page intentionally left blank. 


\section{Stratigraphy and Depositional Environments of the Upper Pleistocene Chemehuevi Formation Along the Lower Colorado River}

By Daniel V. Malmon, Keith A. Howard, P. Kyle House, Scott C. Lundstrom,

Philip A. Pearthree, Andrei M. Sarna-Wojcicki, Elmira Wan, and David B. Wahl

Professional Paper 1786 


\section{U.S. Department of the Interior \\ KEN SALAZAR, Secretary}

\section{U.S. Geological Survey Marcia K. McNutt, Director}

\section{U.S. Geological Survey, Reston, Virginia: 2011}

This report and any updates to it are available online at:

http://pubs.usgs.gov/pp/1786/

For more information on the USGS - the Federal source for science about the Earth, its natural and living resources, natural hazards, and the environment:

World Wide Web: http://www.usgs.gov/

Telephone: 1-888-ASK-USGS

Any use of trade, product, or firm names in this publication is for descriptive purposes only and does not imply endorsement by the U.S. Government.

Although this report is in the public domain, it may contain copyrighted materials that are noted in the text. Permission to reproduce those items must be secured from the individual copyright owners.

Suggested citation:

Malmon, D.V., Howard, K.A., House, P.K., Lundstrom, S.C., Pearthree, P.A., Sarna-Wojcicki, A.M., Wan, E., and Wahl, D.B., 2011, Stratigraphy and depositional environments of the upper Pleistocene Chemehuevi Formation along the lower Colorado River: U.S. Geological Survey Professional Paper 1786, 95 p.

FRONT COVER

Photograph of a typical Chemehuevi Formation outcrop. 


\section{Contents}

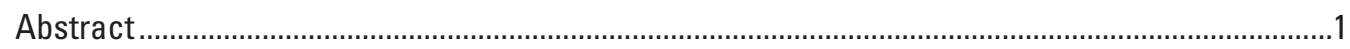

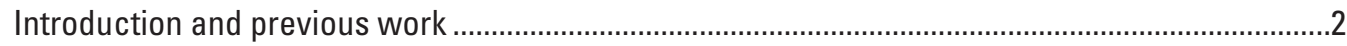

Early studies of the Chemehuevi Formation .........................................................................

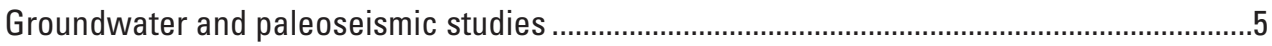

Geologic mapping and geochronology ...............................................................................

Need for a formal definition of the Chemehuevi Formation..................................................

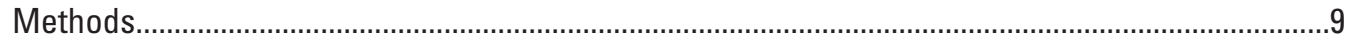

Distribution of the Chemehuevi Formation ...................................................................................10

Geographic distribution .................................................................................................

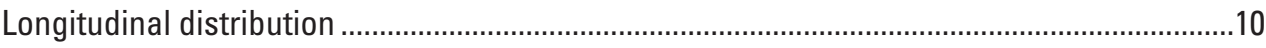

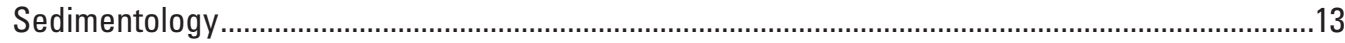

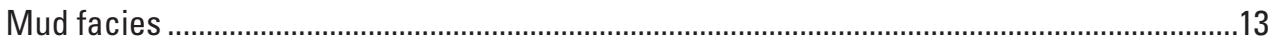

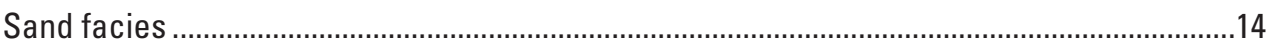

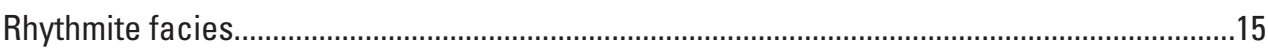

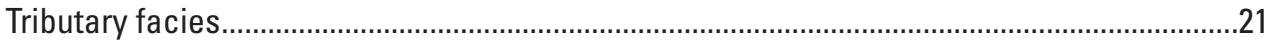

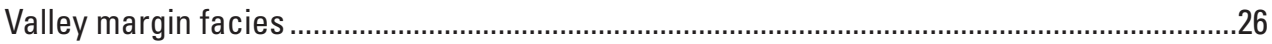

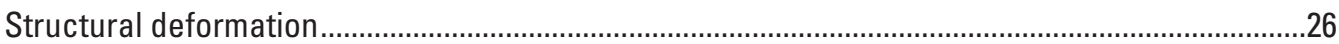

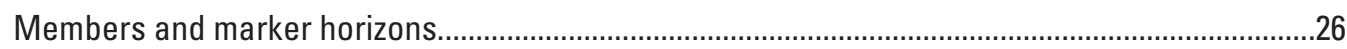

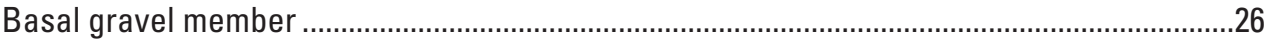

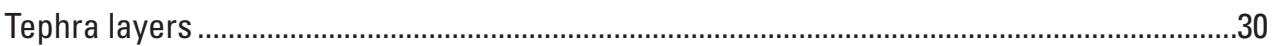

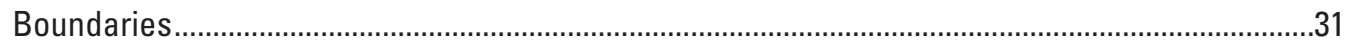

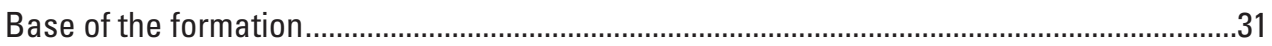

Top of the formation and overlying terrace gravel sequence ..................................................33

No regional internal unconformities.........................................................................................37

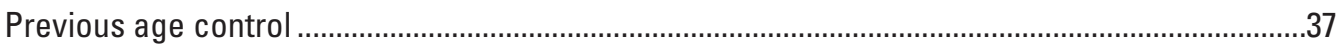

Tephra correlations and age constraints...........................................................................................42

Correlation among tephra layers in the formation .................................................................42

Mammoth Mountain source area .................................................................................................42

Stratigraphic context of chemically similar tephra layers elsewhere.......................................44

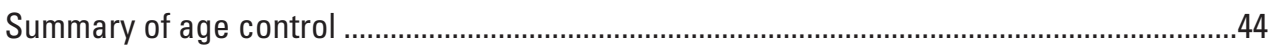

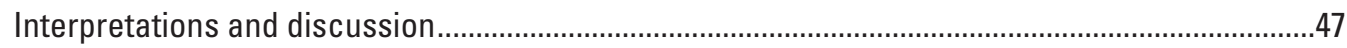

Interpretation of depositional environments........................................................................ 47

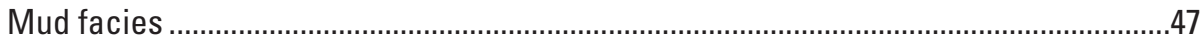

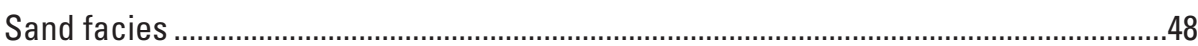

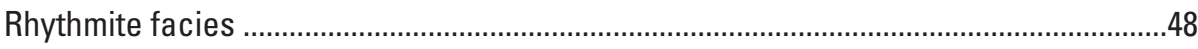

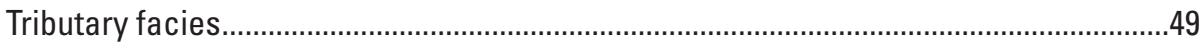

Regional stratigraphic architecture and the sand-over-mud contact..................................49

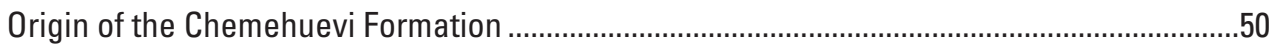

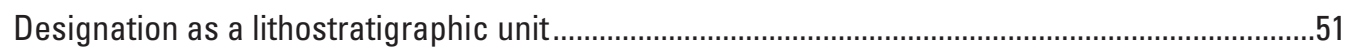

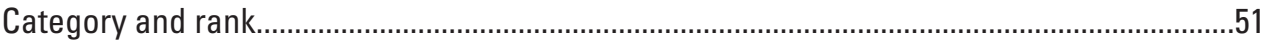

Selection and derivation of name ....................................................................................52

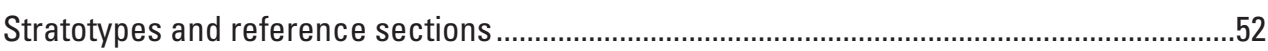

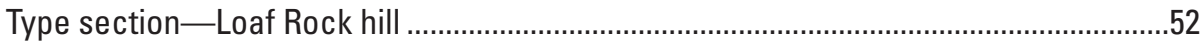


Reference section—Katherine Landing near Loaf Rock ................................................53

Reference section—Old Callville outcrop described by Longwell (1936).......................53

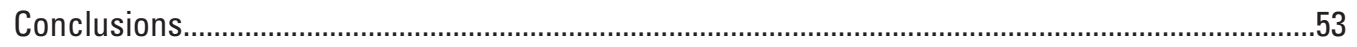

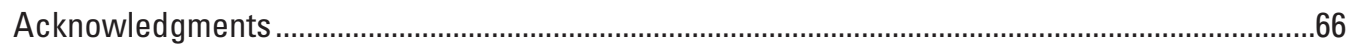

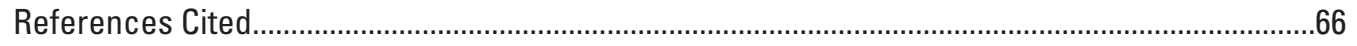

\section{Figures}

1. Photograph of a typical Chemehuevi Formation outcrop.........................................................

2. Maps of study area showing surveyed outcrops and place names ......................................

3. Reproduction of Newberry's sketch of Elephant Hill .........................................................

4. Pre-Lake Mead aerial photograph.....................................................................................

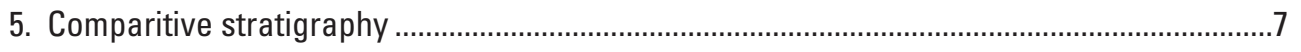

6. Models of the stratigraphic architecture of the Chemehuevi Formation...............................8

7. Longitudinal profile of the Chemehuevi Formation and pre-Hoover Dam valley ..................11

8. Relative thicknesses of sand, silt and clay in selected outcrops........................................12

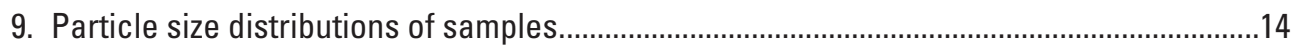

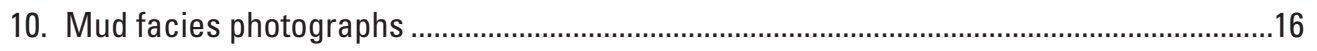

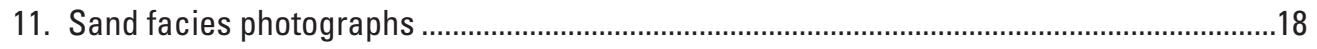

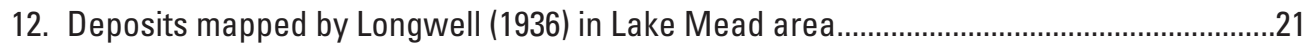

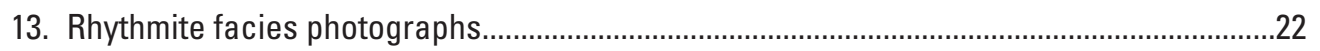

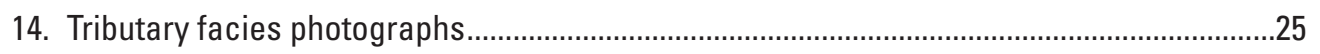

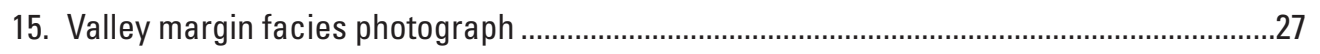

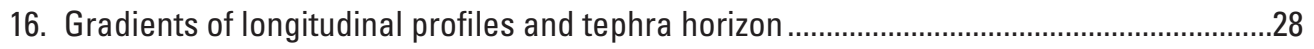

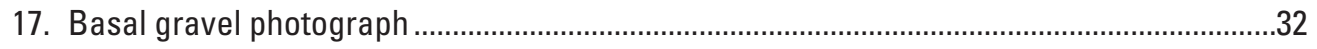

18. Monkey Rock tephra photographs ..................................................................................

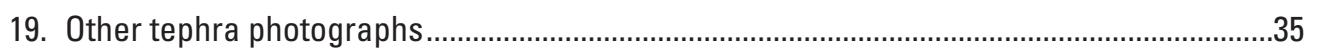

20. Upper stratigraphic boundary of the Chemehuevi Formation ...............................................38

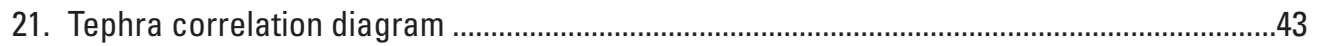

22. Map of volcanic source area and sites of related tephra layers .........................................46

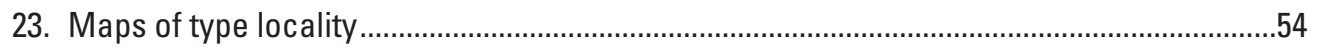

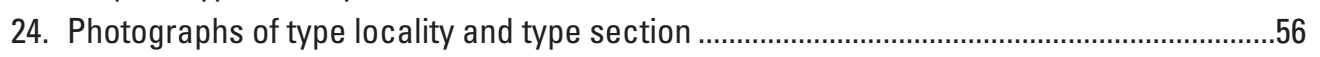

25. Simplified type section................................................................................................... 57

26. Photograph —interfingering of mud and sand near type section.........................................58

27. Photograph and reference section of partly submerged exposure near

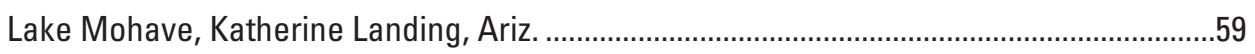

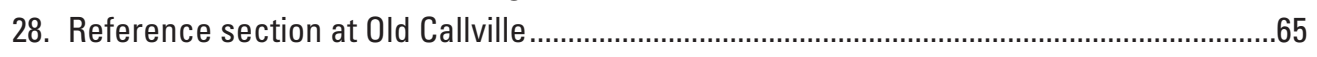

\section{Tables}

1. Grain-size proportions by thickness described from the Chemehuevi Formation ...............13

2. Possible locations of basal gravel member ........................................................................29

3. Geochemistry and stratigraphic context of four tephra layers in the Chemehuevi

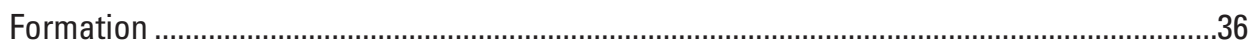

4. Previous age control for the Chemehuevi Formation .........................................................39

5. Correlation matrix for Chemehuevi Formation tephra layers ...............................................40

6. Geochemistry of closest chemical matches to Mammoth Mountain proximal

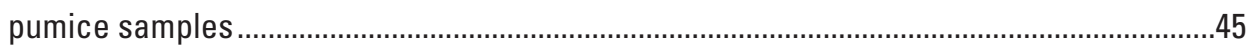

7. Proposed type section of the Chemehuevi Formation at Loaf Rock hill..............................60 


\section{Appendixes}

Appendix 1. Elevation and stratigraphic context of surveyed Chemehuevi Formation

localities. . .72

Appendix 2. Particle size distributions from samples of mud and sand facies ...............................84

Appendix 3. List of outcrops mapped by Longwell (1936), including minimum and maximum

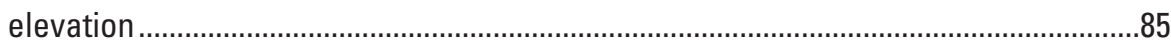

Appendix 4. Old Callville section (from Longwell, 1936) ................................................................

Appendix 5. Sandy Point section (from Longwell, 1936)...........................................................8

Appendix 6. Pearce Ferry sections (from Longwell, 1936) ...........................................................89

Appendix 7. Lithologic log of well LCRP-15 near Blythe (from Metzger and others, 1973).............90

Appendix 8. Detailed measured section surrounding the Monkey Rock tephra layer ...................93

Appendix 9. Detailed measured section near Lake Mohave, Katherine Landing, Ariz....................94 
This page intentionally left blank. 


\title{
Stratigraphy and Depositional Environments of the Upper Pleistocene Chemehuevi Formation Along the Lower Colorado River
}

\author{
By Daniel V. Malmon ${ }^{1,2}$, Keith A. Howard', P. Kyle House ${ }^{3,6}$, Scott C. Lundstrom ${ }^{4}$, Philip A. Pearthree ${ }^{5}$, \\ Andrei M. Sarna-Wojcicki', Elmira Wan'1, and David B. Wahl'
}

\section{Abstract}

The Chemehuevi Formation forms a conspicuous, widespread, and correlative set of nonmarine sediments lining the valleys of the Colorado River and several of its larger tributaries in the Basin and Range geologic province. These sediments have been examined by geologists since J. S. Newberry visited the region in 1857 and are widely cited in the geologic literature; however their origin remains unresolved and their stratigraphic context has been confused by inconsistent nomenclature and by conflicting interpretations of their origin. This is one of the most prominent stratigraphic units along the river below the Grand Canyon, and the formation records an important event or set of events in the history of the Colorado River. Here we summarize what is known about these deposits throughout their range, present new stratigraphic, sedimentologic, topographic, and tephrochronologic data, and formally define them as a lithostratigraphic unit.

The Chemehuevi Formation consists primarily of a bluff-forming mud facies, consisting of gypsum-bearing, horizontally bedded sand, silt, and clay, and a slope-forming sand facies containing poorly bedded, well sorted, quartz rich sand and scattered gravel. The sedimentary characteristics and fossil assemblages of the two facies types suggest that they were deposited in flood plain and channel environments, respectively. In addition to these two primary facies, we identify three other mappable facies in the formation: a thick-bedded rhythmite facies, now drowned by Lake Mead; a valley-margin facies containing abundant locally derived sediment; and several tributary facies consisting of mixed fluvial and lacustrine deposits in the lower parts of major tributary valleys. Observations from the subsurface and at outcrops near the elevation of the modern flood plain suggest that the formation also contains a regional basal gravel member.

\footnotetext{
${ }^{1}$ U.S. Geological Survey, Menlo Park, Calif.

${ }^{2}$ Now at: CH2M HILL, Water Business Group, Portland, Oreg.

${ }^{3}$ Nevada Bureau of Mines and Geology, Reno, Nev.

${ }^{4}$ U.S. Geological Survey, Denver, Colo.

${ }^{5}$ Arizona Geological Survey, Tucson, Ariz.

${ }^{6}$ Now at: U.S. Geological Survey, Flagstaff, Ariz.
}

Surveys of numerous outcrops using high-precision GPS demonstrate that although the sand facies commonly overlies the mud facies where the two are found together, contacts between the two occur over a range in elevation, and as a consequence, the sand and mud facies are similarly distributed both horizontally and vertically throughout the valley. Collectively, the outcrops of the formation lie below a smooth elevation envelope that slopes 50 percent more steeply than the historic (pre-Hoover Dam) valley, from nearly $150 \mathrm{~m}$ above the historic flood plain near the mouth of the Grand Canyon to less than $30 \mathrm{~m}$ above the flood plain at the head of the flood plain near Yuma, Arizona. The steepness of the valley at the peak of aggradation probably represents a depositional slope.

Layers of fine grained volcanic tephra have been found below and within the Chemehuevi Formation at five widely separated sites, one of which is now submerged beneath Lake Mead. Major element geochemistry of glass shards from the four accessible tephra sites were analyzed. Three of the sampled tephra layers are interbedded within the Chemehuevi Formation, and a fourth tephra conformably underlies the formation. The three interbedded tephra layers are similar enough to one another that they are probably from the same eruptive unit, hereafter referred to as the Monkey Rock tephra bed. The other sample, which locally underlies the formation, is similar enough to the Monkey Rock tephra bed to suggest it is from the same volcanic source area; however, it may not be from the same eruption, and thus may not be the same age. On the basis of the stratigraphic contexts of chemically similar tephra layers found elsewhere in the Basin and Range, we suspect that the source area is the Mammoth Mountain dome complex in Long Valley, east-central California. Two samples of proximal Mammoth Mountain pumice were analyzed and produced geochemical signatures similar to all four of the Chemehuevi Formation tephra, supporting Mammoth Mountain as a possible source area. The Mammoth Mountain volcanic center produced eruptions between about $111 \pm 2$ and $57 \pm 2 \mathrm{ka}$ and was most active in the later part of this time interval, during Marine Oxygen Isotope (MOI) stage 4 (between 74 and $59 \mathrm{ka}$ ago). Chemically similar tephra in cores from Owens Lake and Walker Lake are approximately 70 and 74 ky old, based on age models of those cores. Other lines of stratigraphic 
evidence from nine tephra-containing sections in the Basin and Range are also consistent with an age assignment for the Monkey Rock tephra of $\sim 72 \mathrm{ky}$, near the beginning of MOI stage 4.

We propose to designate the Chemehuevi Formation as a formal lithostratigraphic unit, and propose as the type section a well exposed outcrop near the ranger station at Katherine Landing, Arizona, in the Lake Mead National Recreation Area. This exposure shows the two dominant facies, an example of one of the four known tephra layers, and interbedded lenses of locally derived gravel. In the type section, as in many of the other examples of the formation, the sand facies overlies the mud facies on a conspicuous, abrupt erosional surface; however, nearby is a contiguous section demonstrating that the mud and sand facies interfinger. In addition to the type section, measured reference sections compiled here illustrate other important lithologic and stratigraphic features of the formation.

Our preferred interpretation of the Chemehuevi Formation is that it contains the remnants of deposits formed during a single major episode of fluvial aggradation, during which the Colorado River filled its valley with a great volume of dominantly sand-size sediment. This would reflect an increase in the supply of sand-size sediment, and (or) a reduction in transport capacity below the mouth of Grand Canyon. The most likely cause for the aggradation is an extraordinary increase in sand supply, likely due to widespread climatic change. However, other explanations have not been ruled out. Other aggradation events predated the Chemehuevi Formation, and some smaller events may have postdated the formation.

However, the Chemehuevi Formation contains the remnants of the most recent large magnitude $(>100 \mathrm{~m})$ aggradation of the Colorado River.

\section{Introduction and Previous Work}

A conspicuous set of fine-grained deposits lines the valleys of the lower Colorado River and some of its tributaries in the Basin and Range geologic province (fig. 1). These deposits are the most prominent remnants of the Pleistocene part of the stratigraphic record of the Colorado River below the Grand Canyon. Deposits of similar character and position in the landscape are distributed throughout the main Colorado River valley from the mouth of Grand Canyon (where the river exits the Colorado Plateau) into the subsiding river delta below Yuma, Arizonaa valley distance of over $700 \mathrm{~km}$. The beds consist of sediment carried by the ancestral Colorado River and its tributaries and are Pleistocene in age (Newberry, in Ives, 1861), in places unconformably overlying cemented Pliocene and older Pleistocene Colorado River deposits (Lee, 1908; Longwell, 1936; Metzger and others, 1973; House and others, 2005a).

Upstream of Parker, Arizona, these Pleistocene deposits occur as scattered erosional remnants as much as $150 \mathrm{~m}$ above the modern flood plain. Below Parker, they occur in isolated outcrops but also underlie large continuous terraces such as
Parker Mesa, Palo Verde Mesa, and Yuma Mesa (fig. 2). The deposits are commonly characterized by a distinctive two-part stratigraphy (fig. 1) consisting of a bedded mud sequence that forms bluffs and badlands and an overlying slope-forming succession of poorly consolidated quartz-rich sand and minor gravel. Beds with these characteristics occupy similar stratigraphic positions throughout the Colorado River valley downstream of Grand Canyon, and can be traced to fluvial sequences in at least three major tributary valleys.

W. T. Lee (1908) called these sediments, along with overlying fluvial gravels, the "Chemehuevis gravel." Longwell (1936) pointed out that the gravels were part of an overlying sequence, and that the bulk of the formation was composed of the finer grained beds, which he referred to as the "Chemehuevis formation" (Longwell, 1936), and later, the "Chemehuevi lake beds" (Longwell, 1946), and the "Chemehuevi Formation" (Longwell and others, 1965). Longwell's incomplete definition of the formation has led to ambiguities over what is included in the unit, resulting in discrepancies in concept and among geologic maps of the region created by different geologists. Many geologists have observed that the formation must record a set of geologically significant events in the river or its watershed but have offered conflicting interpretations of the timing and origin of these sediments. In an attempt to reduce mapping ambiguities and facilitate future studies of the Pleistocene history of the Colorado River, we systematically document the characteristics of these deposits throughout their range, and propose to formally define them as a lithostratigraphic unit called the Chemehuevi Formation.

\section{Early studies of the Chemehuevi Formation}

Conspicuous, fine-grained, Pleistocene Colorado River sediments were first documented by the geologist J. S. Newberry, who accompanied the Ives expedition to investigate the navigability of the lower Colorado River in 1857-58. Newberry [as reported in Ives (1861)] identified a sand, silt, and clay-dominated Quaternary deposit unconformably overlying tilted Tertiary strata near the mouth of the Bill Williams River, and stated that similar deposits occur in many localities throughout the lower Colorado River valley, forming bluffs and terraces as much as 250 feet above the river. He discovered a fossil elephant tooth in gravel underlying similar beds at Elephant Hill, at the mouth of Black Canyon (fig. 3). Newberry surmised that the sediment containing the tooth must have been deposited by a deep flow of water "two hundred feet or more above its present level, while in this locality the bottom was nearly as low as it now is."

Lee (1908) noted that the distinctive Pleistocene deposits are distributed all along the Colorado River valley, and called them the "Chemehuevis gravel," for exposures in Chemehuevis (now Chemehuevi) Valley (fig. 1). He identified this unit, including a series of fine-grained beds, as far upstream as Iceberg Canyon near the mouth of Grand Canyon. He noted that "Chemehuevis gravel" commonly fills abandoned paleovalleys cut into bedrock and older gravel, and he described 
key localities in Cottonwood Valley, at the mouth of Pyramid Canyon (near modern Davis Dam), in Mohave Cañon (now referred to as Topock Gorge), and in "Chocolate Canyon," upstream of Yuma, Arizona. Lee (1908, p. 42) pointed out a distinguishing characteristic of the deposits near the present site of Davis Dam: "The lower division consists mainly of well-stratified and firmly packed sand and silt: the upper of stratified but very loose sand and gravel." He attributed the coarsening-upwards stratigraphy as "due to some change in the river, such as an increase in its carrying power, enabling it to bear the finer material away and deposit only the coarser material; or to a change in course, bringing the gravel-bearing current over what had formerly been a flood plain." This two-part stratigraphic character has been frequently cited since Lee's time, but some later studies disputed Lee's (1908, p. 42) claim that "The two divisions appear to be perfectly conformable." Lee indicated that he observed Chemehuevis gravel beneath basaltic lava in Las Vegas Wash, but this outcrop has not been reidentified. He also noted that the stratification found in Chemehuevis beds (presumably referring to the lower, well-stratified fine-grained part) resembles that of the annual silt layers deposited by the contemporary (pre-Hoover Dam) Colorado River on its flood plain.

In anticipation of flooding behind Hoover Dam, C. R. Longwell (1936) spent February through June of 1934 conducting a systematic geologic survey of the area below the high stand of future Lake Mead "to avoid permanent loss of possibly critical geologic information" (p. 1395). He documented a diverse geologic history over a large area in a short time, and included an extensive description and interpretation of the Pleistocene deposits described by Lee (1908), which he referred to the "Chemehuevis formation." Longwell (1936) mapped a number of remnants of the formation along the valleys of the Colorado and Virgin Rivers, and near the

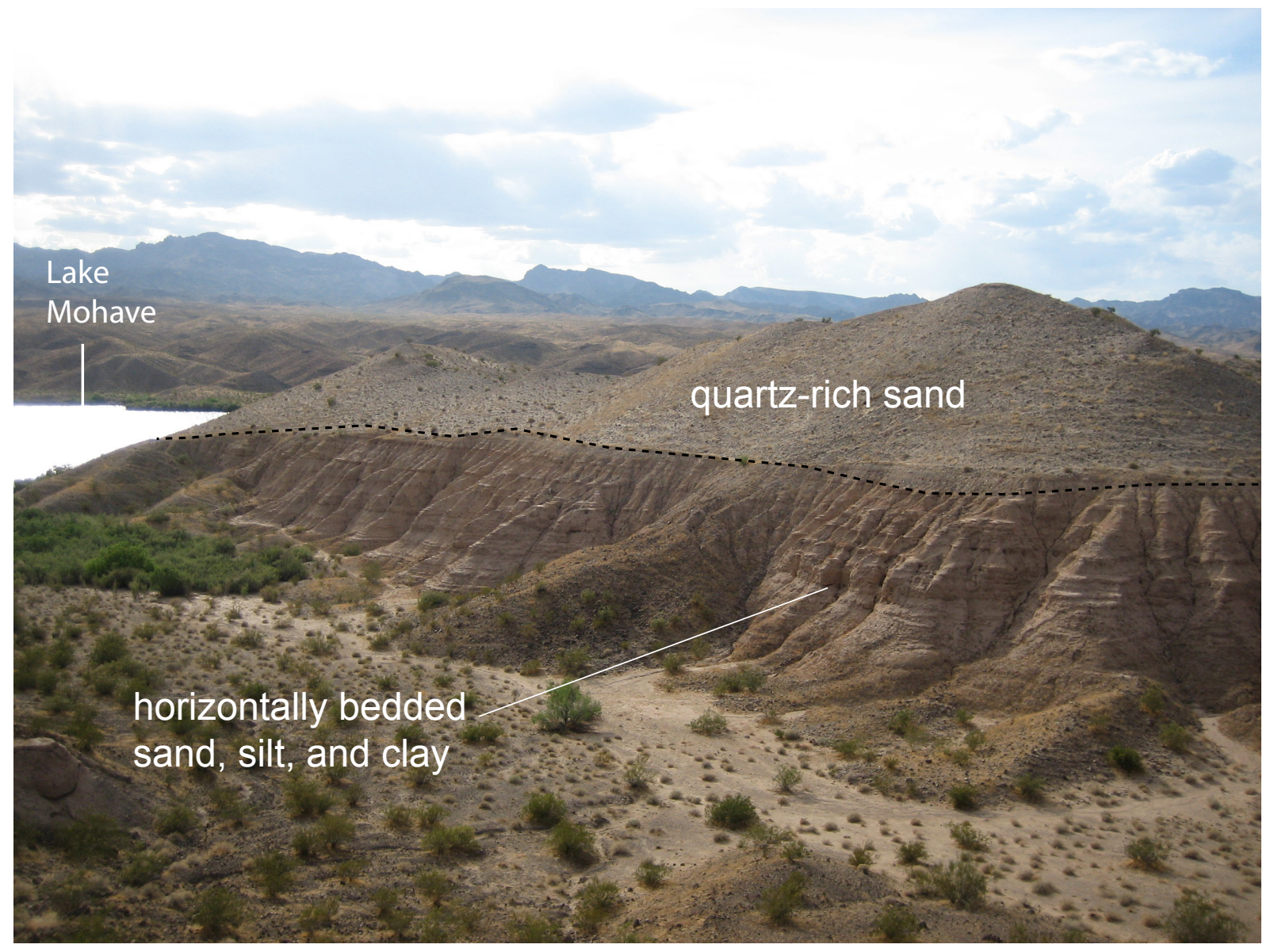

Figure 1. Photograph of a typical outcrop of the Chemehuevi Formation, showing sand-over-mud outcrop-scale stratigraphy. View is toward the west, near the inlet to a paleovalley east of Lake Mohave, in U.S. Geological Survey Fire Mountain 7.5' quadrangle, near the mouth of Black Canyon, Ariz. (Appendix 1, locality 07-501-4). 
$\boldsymbol{A}$

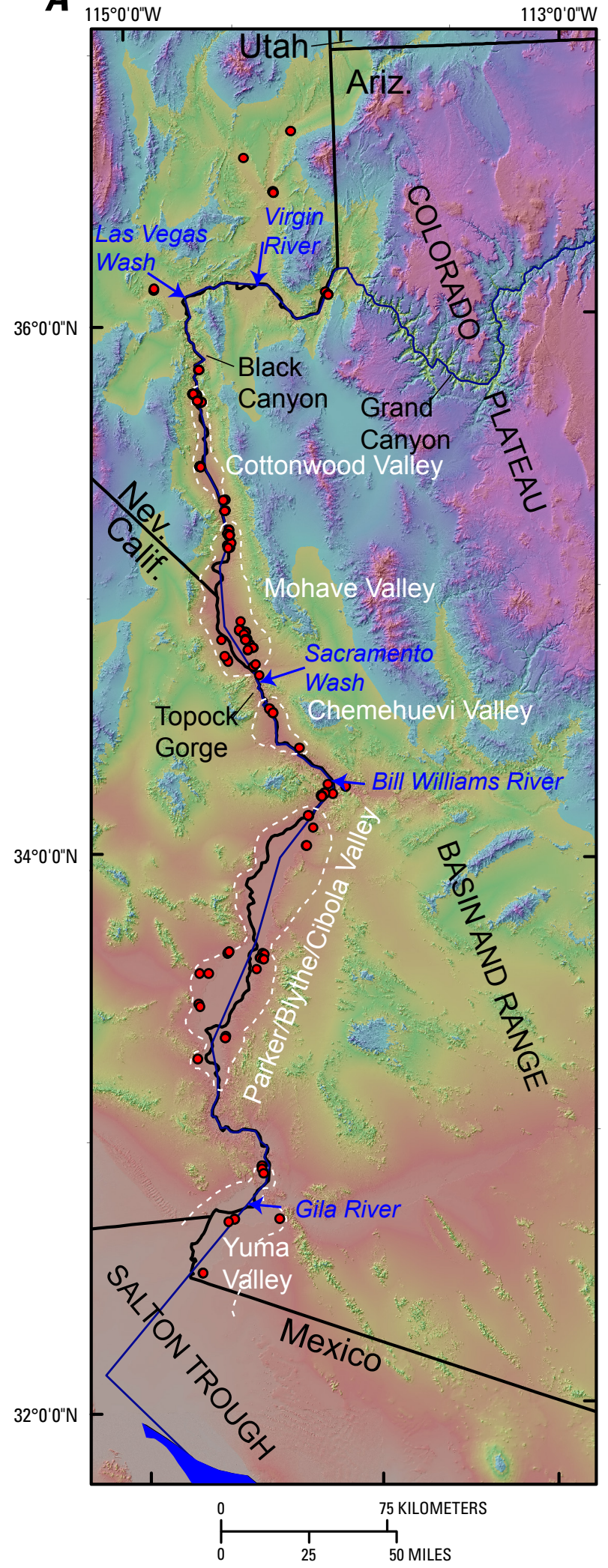

B

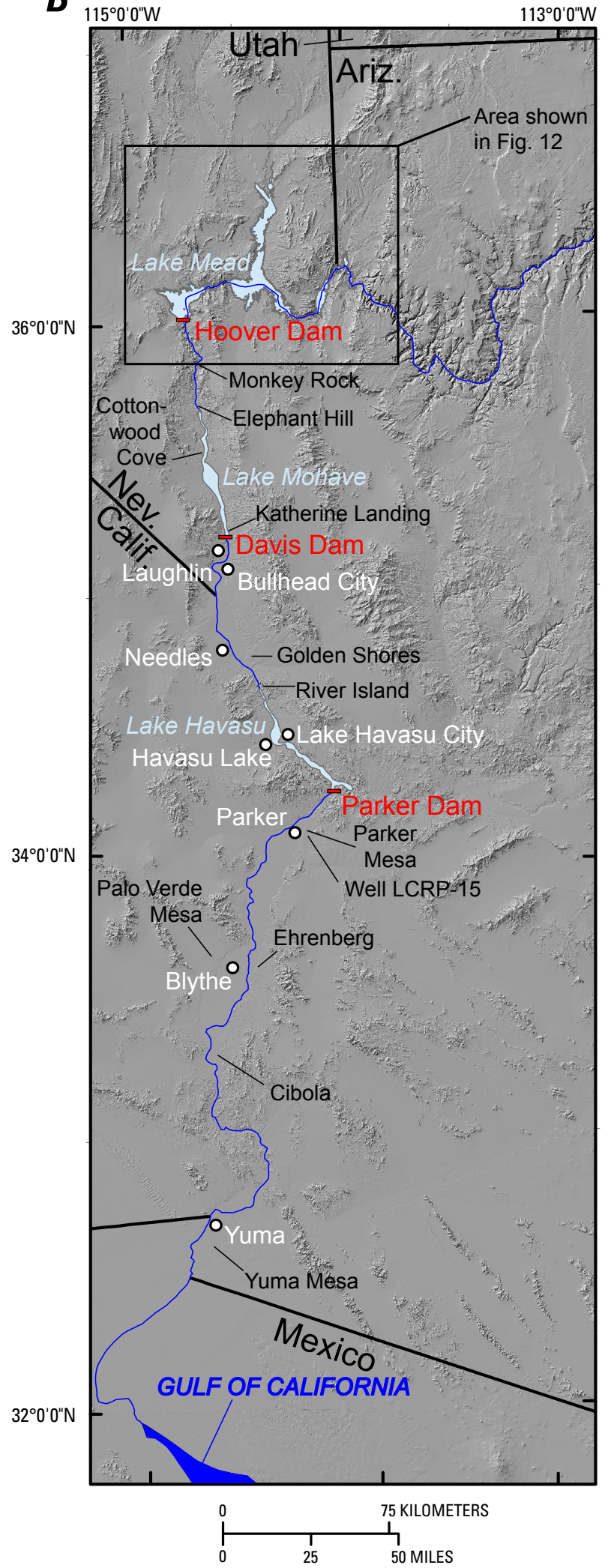

Figure 2. Location maps of the lower Colorado River Valley. $A$, Shaded relief draped over color elevation model showing outcrops visited and surveyed (red points; see appendix 1 for site descriptions). Dark blue line shows "valley line" (explained in text), blue arrows mark mouths of major tributaries below Grand Canyon, white dashed lines approximately delineate wide alluvial valley reaches, and some narrow canyon reaches are labeled in black lettering. $B$, Shaded-relief map showing locations referred to in text, major dams and reservoirs, and extent of figure 12, which shows the Lake Mead area in greater detail. 
mouth of Las Vegas Wash. He reported a vertical range of nearly $200 \mathrm{~m}$ for remnants of flat-lying Chemehuevis formation deposits throughout the area now drowned by Lake Mead, and described the most complete exposure near Old Callville, west of Boulder Canyon, as having "practically every layer... exposed through a thickness of nearly 400 feet" (p. 1444). This section is now mostly submerged by Lake Mead, but its erosional landforms and light tone are visible in pre-Hoover Dam aerial photographs (fig. 4), and the landforms are also clear in pre-Hoover Dam topographic maps. Longwell (1936, p. 1450) inferred that the deposits of the Chemehuevis formation record a single aggradational episode (fig. 5A, 6A), resulting either from an overloaded condition of the river or in a lake because the river was impounded. He finally concluded that the sediments were deposited in a deep Pleistocene lake (Longwell, 1946; 1963). The entire sequence is overlain by a sequence of fluvial "terrace gravel" deposits at a variety of elevations, deposited as the river reincised back through the lacustrine fill.

\section{Groundwater and Paleoseismic Studies}

Metzger and others (1973) and Metzger and Loeltz (1973) conducted detailed investigations of lower Colorado River stratigraphy as part of a regional hydrogeologic study for the two widest valley sections (Mohave Valley and the Parker-Blythe-Cibola Valley; fig. 2). On the basis of surface exposures and well-log data, Metzger and others (1973) developed a general stratigraphic framework for the late Cenozoic lower Colorado River valley. They subdivided the older alluvium into five units, of which unit D and overlying $\mathrm{E}$ were equivalent, respectively, to the bedded mud and sand-dominated facies of Longwell's (1936) Chemehuevis formation (fig. 5B). Metzger and others (1973, p. G29) and Metzger and Loeltz (1973, their fig. 14) reported that units D and E are separated by an erosional unconformity (for example, fig. 1), which they interpreted as a regional unconformity, and for that reason did not consider the deposits as a single formation.

Metzger and others (1973) disputed Longwell's interpretation of the beds as lacustrine, because of the absence of a suitable natural dam and the fact that the deposits extend from Grand Canyon into the delta region. Their alternative interpretation of the stratigraphy was that unit $\mathrm{D}$, the bedded mud facies, was deposited during a single, relatively uninterrupted aggradational phase, and unit $\mathrm{E}$, the gravelly sand facies, was deposited by the river during oscillations in an overall period of long-term river downcutting (fig. 6B).

Additional stratigraphic observations and interpretations of the late Pleistocene stratigraphy of the lower Colorado River, including the first numerical age data from the Chemehuevi Formation, are reported in technical reports of studies related to the licensing of two proposed nuclear power reactors in the lower Colorado River Valley: the Sundesert and Vidal projects (Fugro, Inc., 1975; Woodward-McNeill and Associates, 1977). These studies examined the stratigraphy of the Blythe and Parker areas, including both river and fan deposits, to assess the seismic hazard of the area. As part of this work, Lee and Bell (1975) interpreted the gravelly sand facies of the formation as bed-load deposits of the Colorado River, and the bedded mud facies as suspended and overbank deposits. They also speculated that that these deposits might be the aggregate remnants of several episodes of river aggradation, an interpretation supported by more recent work (Faulds, 1996a,b; House and others, 2005b). Lee and Bell (1975) also pointed out that the collection of deposits delineate a regionally steeper slope compared with the gradient of the current valley floor, noting

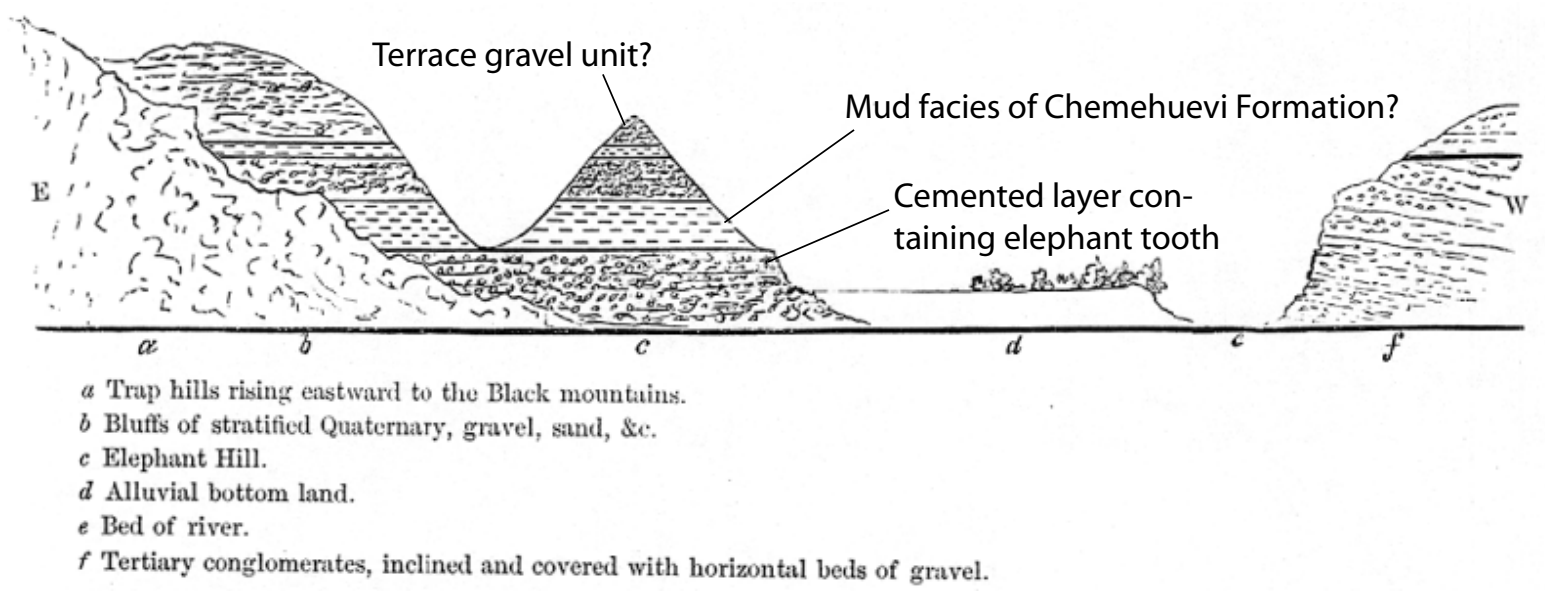

Figure 3. Reproduction of sketch of Elephant Hill, near the mouth of Black Canyon, from J.S. Newberry (in Ives, 1857); annotations added. Newberry reported finding an elephant tooth in the gravel underlying sediments now recognized as the Chemehuevi Formation, which underlies Elephant Hill. 
maximum elevations in the Parker-Blythe-Cibola region are as high as 200 feet above the valley floor, 300 feet in the Needles area, and more than 400 feet above the historic flood plain in eastern Lake Mead.

\section{Geologic Mapping and Geochronology}

The Chemehuevi Formation has appeared on some geologic maps of the lower Colorado River corridor, including Longwell's $(1936,1960)$ maps of the Lake Mead area. Lucchitta (1966) mapped the Chemehuevi Formation in the eastern Lake Mead area, describing it as uncemented, lightcolored, regularly bedded sand, silt, and clay unconformable on older rocks, located close to the Colorado River, and in places "separated from terrace gravels by gently sloping surface of low relief" (p. 168). John (1987) mapped the Chemehuevi Formation of Longwell (1963) as sand, silt, clay, and ancestral Colorado River gravel and cobbles in Topock Gorge (fig. 1). Bales and Laney (1992) mapped the Chemehuevi Formation in the Lake Mead area (including in the Overton Arm, which drowns the lower part of the Virgin River valley) and described it as "white, pink, tan, thin-bedded, wellsorted unconsolidated fine sand." Faulds (1996a, b) mapped deposits in Cottonwood Valley (fig. 1) as the Chemehuevi Formation of Longwell (1963), and distinguished mud-, sand-, and gravel-dominated facies. However, he included river alluvium possibly spanning the late Miocene through Pleistocene within this map unit, including beds that probably underlie and overlie the Chemehuevi Formation as defined in this report. Faulds' (1996a, b) interpretation of the finegrained part of the river deposits was that they were composed of the remnants of multiple aggradation-degradation cycles of the Colorado River in late Pleistocene time.

Blair (1996) revisited many of Faulds' outcrops in an attempt to better understand the origin of the deposits. He analyzed samples petrographically, presented particle size data, and examined several possible mechanisms for the formation of the beds in the study area. He concluded that the Colorado River must have undergone a geomorphic shift between the deposition of the mud facies and the sand facies and argued that the mud and sand beds must be younger than Lee and Bell (1975) believed, because they are so erodible they would not have been preserved hundreds of thousands of years. This assertion was supported by a single, finite radiocarbon date of $35.1 \pm 0.4 \mathrm{ka}$ he obtained from a piece of wood found in place at an outcrop about $4 \mathrm{~km}$ from the location where Newberry (in Ives, 1961) discovered the elephant tooth.

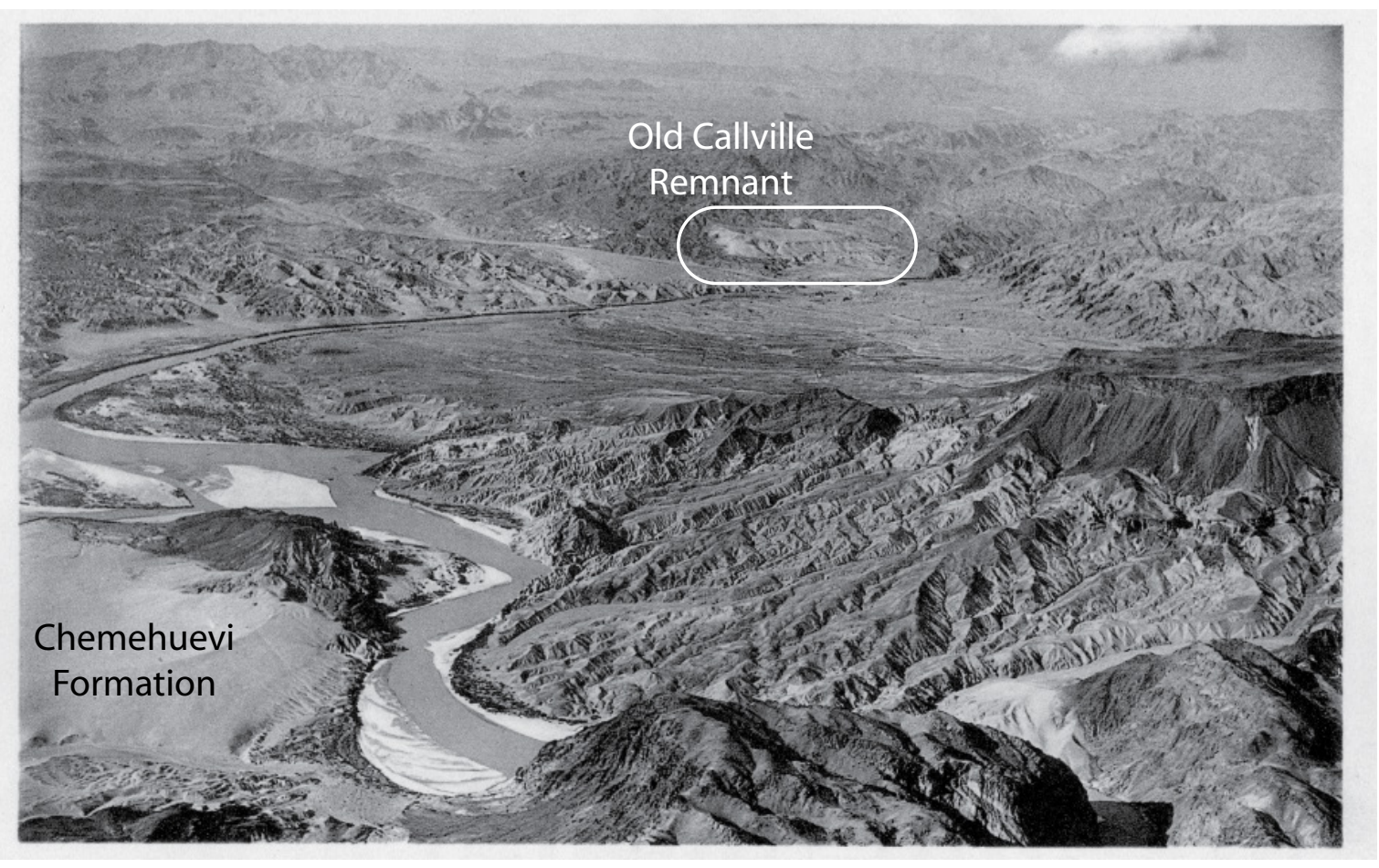

Figure 4. Aerial view of the Boulder Basin area behind Hoover Dam, before the filling of Lake Mead; modified from Longwell (1936) by adding text on photograph. Deposit circled is the Old Callville remnant of the Chemehuevi Formation described by Longwell (1936). Another prominent remnant of the formation is labeled in the left foreground. 
House and others (2005b) presented the findings and interpretation of detailed surficial geologic mapping of several quadrangles in Cottonwood Valley and upper Mohave Valley (Faulds and others, 2004; House and others, 2004; Pearthree and House, 2005; House and others, 2005a). Their studies led them to conclude that the characteristic deposits that Longwell (1936) had informally named the "Chemehuevis formation"that is, flat-bedded mud and fine sand overlain by a thick package of loose, gravelly sand - includes a series of similar, disconformable sequences related to multiple aggradation events (fig. 6C). This interpretation was supported by the presence of erosional unconformities juxtaposing similar sequences of bedded mud facies, including a prominent one in Nevada $2.5 \mathrm{~km}$ downstream from Davis Dam (fig. 2)

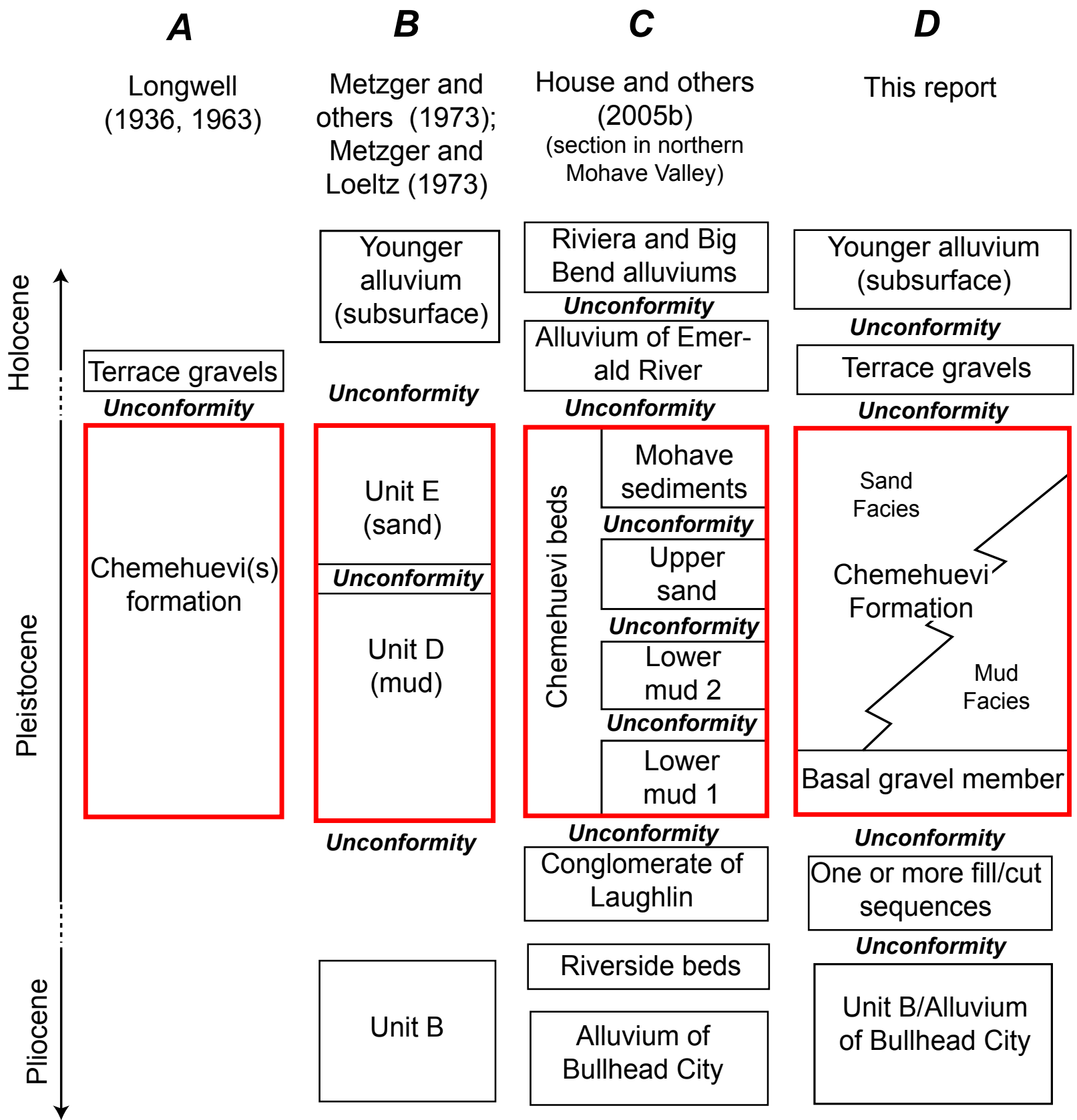

Figure 5. Various authors' conceptions of the late Cenozoic stratigraphy of lower Colorado River sediments. The Chemehuevi Formation, as envisioned here, includes the sediments enclosed within the red boundary in each column. Only Colorado River deposits are listed; intervening or interbedded alluvial fan gravel sequences are not shown. 


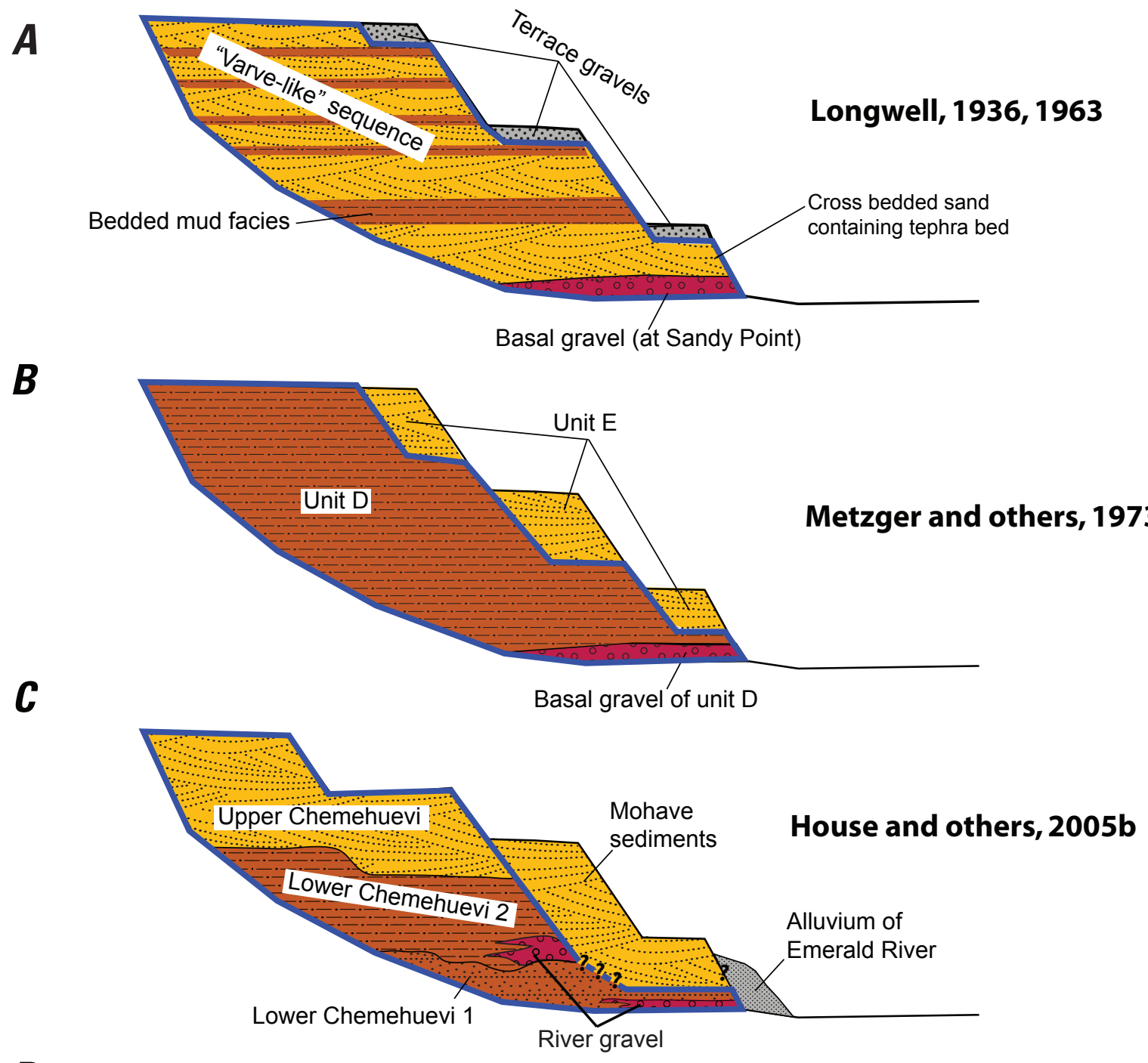

D

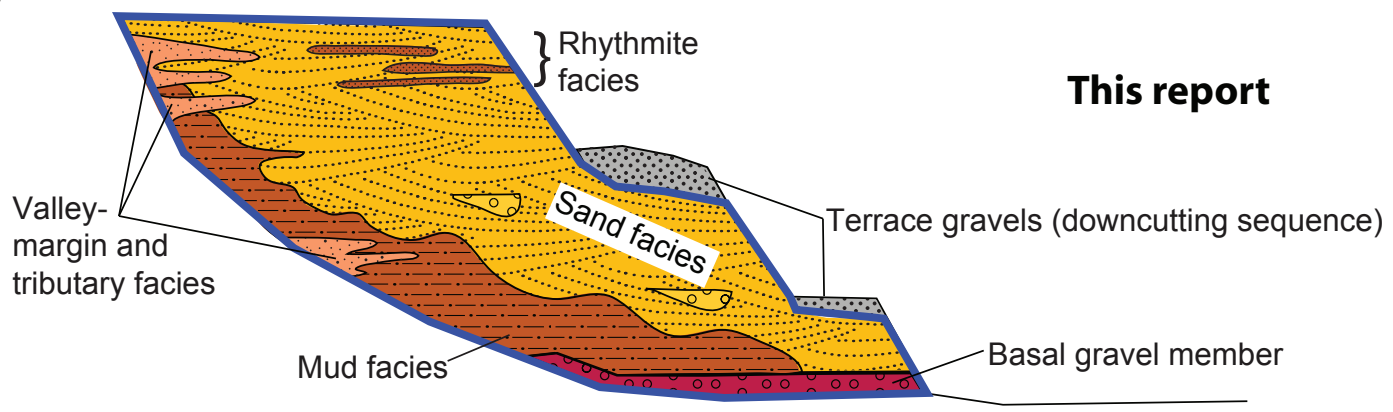

Figure 6. Alternative models of the stratigraphic architecture of the Chemehuevi Formation. Thick blue line encompasses sediments believed by the authors to belong to the aggradational sequence of the formation. Alluvial fan units are not shown. $A$, continuous aggradation sequence of sand and mud, unconformably overlain by younger inset terrace gravels (Longwell, 1936, 1963), $B$, aggradation sequence of mud unconformably overlain by degradation sequences of sand and gravel deposited in terraces (Metzger and others, 1973), $C$, multiple inset sequences of mud and gravelly sand separated by erosional unconformities (House and others, 2005b), D, aggradational sequence of flood-plain mud and channel sands, followed by degradation sequence of terrace gravel. 
(Faulds and others, 2004; House and others, 2005b). Quadrangle mapping here and in the nearby lower Cottonwood and upper Mohave valleys led House and others (2005b) to develop a detailed stratigraphy that divided the Chemehuevilike beds into at least three inset sequences that were given informal names (fig. 6C). In the Needles area, Malmon and others (2009a) mapped and described the Chemehuevi Formation of Longwell (1963) as a single stratigraphic unit composed of an assemblage of fine and coarse-grained river deposits bounded above and below by unconformable contacts with other units. Geologic mapping in lower Mohave Valley distinguished several facies of the formation and also reported a similar, older sequence of beds that reached even higher elevations than the Chemehuevi Formation (Malmon and others, 2009a).

Lundstrom and others (2008) reported new observations, dates, and interpretations of the late Pleistocene deposits of the lower Colorado River. They pointed out the inconsistency of previous usage of the name Chemehuevi Formation, so avoided using that name for the deposits. They found normal magnetic polarity and no evidence of secular variation over a $15-\mathrm{m}$-thick section of the mud-dominated facies near Cottonwood Cove, Nevada, which led them to suggest that the section had been deposited relatively rapidly. In addition, they reported luminescence dates on the mud facies and ${ }^{230} \mathrm{Th}$ dates on carbonate coatings on fluvially transported gravels inset into the Chemehuevi-like muds, and interpreted they were deposited in the late Pleistocene, possibly between about 40 and $70 \mathrm{ka}$. Howard and others (2008) describe several abandoned paleovalley segments occupied by the Chemehuevi Formation, and interpreted them as having been abandoned during subsequent river incision into the valley fill.

\section{Need for a Formal Definition of the Chemehuevi Formation}

In summary, the distinctive Colorado River deposits that have been variously referred to as the Chemehuevis gravel (Lee, 1908), the Chemehuevis formation (Longwell, 1936, 1946), the Chemehuevi Formation or Chemehuevi lake beds (Longwell and others, 1965; Bell and others, 1978; John, 1987; Faulds, 1996a,b), units D and E (Metzger and others, 1973), Qrd (Lee and Bell, 1975), and the Chemehuevi and Mohave sediments or beds (House and others, 2005b) appear to record at least one major episode of valley filling, which was followed by reincision of the Colorado River during late Pleistocene time. The cause and the timing of these events remain unclear and requires further research. However, field observations and mapping have demonstrated that these beds constitute a mappable unit in the lower Colorado River area, characterized by distinct facies types and occupying a similar stratigraphic position. Moreover, because the inconsistent usage of the nomenclature has led to confusion about which sediments to include in the unit, and therefore confusion regarding the history of the Colorado River, below we formalize a stratigraphic nomenclature for the deposits by proposing to define the Chemehuevi Formation as a lithostratigraphic unit, following the requirements of the North American Stratigraphic Code (North American Commission on Stratigraphic Nomenclature, 2005). The intention of formally defining the Chemehuevi Formation is to aid future mapping and geologic studies of the history of the Colorado River.

\section{Methods}

We used standard stratigraphic and sedimentologic techniques to characterize the formation in the field and laboratory. Stratigraphic sections were generally measured by two or three people in the field, by laying out tape and measuring the slope of the section using a Brunton compass. Outcrop colors were estimated using a Munsell soil color chart (Munsell Company, 1992) and were made for dry sediment and in direct light (where possible). The degree of carbonate soil development was described using a standard set of criteria for estimating the stages of development of carbonate soil morphology in gravel and sand-rich substrates (Machette, 1985; his table 1). Median grain size was estimated in the field using a hand lens and a field grain size card. For more detailed grain size distributions, dry field samples were suspended in water and analyzed using a laser particle size analyzer by M. Kirby at California State University in Fullerton.

We conducted a survey of the Chemehuevi Formation using high precision GPS in order to (1) create a topographic profile for relating outcrops separated by large distances (2) to reconstruct the shape of the body of sediment at the time of maximum valley aggradation and (3) to provide a basis for comparing the topography of the Colorado River Valley in Chemehuevi time with that of the historic valley. We visited outcrops of the formation throughout its range, and collected observations and high-precision GPS data at 228 locations (appendix 1). Surveys were conducted using a hand-held GPS unit (model: Trimble GeoXT) while standing on the outcrops. At each GPS site, 30 location fixes were recorded, and these data were postprocessed using proprietary software to apply an atmospheric correction derived from contemporaneous data collected at nearby fixed base stations. The average elevation error for the corrected measurements is on the order of 1 meter, which is the average absolute value of the difference between surveyed and known elevations at 30 surveyed benchmarks.

To compare the longitudinal profile of the Chemehuevi Formation fill with the profile of the historic valley floor, $\mathrm{T}$. Felger (U.S. Geological Survey, Flagstaff, Ariz.) computed the valley distance for each outcrop relative to the Colorado River valley axis. We use valley distance rather than channel distance as a distance metric in order to discount the influence of changes in the sinuosity on the slope of the Colorado River 
over geologic time. The valley axis follows the valley trend as defined by flanking bedrock uplands: straight through wide valley segments, but closely following the channel in confined canyon segments (fig. 2A). Valley distances were computed for both the surveyed outcrops and for the historic (pre-Hoover Dam) river surface elevation, as depicted in detailed planetable maps created by U. S. Geological Survey expeditions in 1902-3 and 1924 (U.S. Geological Survey, 1927). The latitude, longitude, valley distance, and elevation data for all visited outcrops are presented in appendix 1, along with basic stratigraphic notes about each locality.

Samples of distal volcanic ash (tephra) and proximal air fall pumice were processed and analyzed by the USGS Tephrochronology Project (D. Wahl and E. Wan). For each sample, glass shards were separated and described qualitatively by an experienced technician. Analysis of hand picked glass shards was conducted on electron mass spectrometer. The percent values of major oxides in the glass shards were then compared with a database of over 6,000 tephra samples mostly from the western conterminous United States. Geochemically similar matches were identified using an algorithm that accounts for six non mobile major oxides (Borchardt, 1974).

We also attempted to date the distal ash directly using the ${ }^{40} \mathrm{Ar}-{ }^{39} \mathrm{Ar}$ method of dating (Faure, 1986). A sample of the tephra from the Monkey Rock locality (appendix 1, locality 05-94) was treated in an ultrasonic bath to break up glass shards, sieved, and washed in heavy liquids to separate primary feldspar crystals. No suitable feldspar crystals were found. More than 95 percent of the sample consisted of fine-grained glass shards, and the remainder consisted of fine biotite grains that were considered unsuitable for dating. In the absence of datable mineral grains, we attempted isotopic analysis directly on three separate samples of the glass. All three samples yielded a disturbed argon release spectrum and no useful results regarding the age of the sample (A. Calvert, USGS, Menlo Park, Calif., written comm., 2007).

\section{Distribution of the Chemehuevi Formation}

\section{Geographic Distribution}

The Chemehuevi Formation is distributed along the Colorado River corridor and in some tributary valleys in the Basin and Range geologic province (fig. $2 A$ ). The width of this belt varies from less than $2 \mathrm{~km}$ in narrow canyon reaches to as much as $35 \mathrm{~km}$ near Blythe, Calif. Deposits of possibly similar age and stratigraphic position located in the Grand Canyon do not have similar lithology to the Chemehuevi Formation (Anders and others, 2005). Although those deposits are probably related to Chemehuevi Formation, they are not included in the formation, which is considered here to be confined to the Basin and Range geologic province.
We studied remnants of the formation along the main valley of the Colorado River from near the mouth of Grand Canyon to the southern international boundary with Mexico at San Luis Rio Colorado, south of Yuma, Arizona, and in the lower parts of some tributary valleys (fig. 2, appendix 1). Sediments of the Chemehuevi Formation are abundant in the Grand Wash Trough, the first significant depositional basin below the Grand Canyon. The most upstream remnant of the Chemehuevi Formation is north of the river, approximately $3 \mathrm{~km}$ below the terminus of Grand Canyon at the mouth of Lower Granite Gorge. This deposit, and a larger one across the river to the south (near Pierce Ferry), were mapped and described by Longwell (1936). Historic sedimentation at the delta of Lake Mead has since buried most of these deposits, so that outcrops are no longer accessible even during low lake stands. Notable deposits of the formation near the mouth of Grand Canyon also include a prominent one at Sandy Point (25 km downstream from Grand Canyon, appendix 1, locality $05-145$ ) and a nearby, slightly higher outcrop $1 \mathrm{~km}$ to the southeast, between Sandy Point and South Cove (appendix 1, locality 05-305).

The Chemehuevi Formation can be traced into the tectonically subsiding delta of the Colorado River, south of Yuma, Arizona (fig. 2B). Deposits correlative to the Chemehuevi Formation extend into Mexico as part of a complex of structurally deformed deltaic deposits near the head of the Gulf of California; possibly correlative deposits also project into the Salton Basin, where they may have been mapped as different units (Diblee, 1954, 1984; Winker, 1987; Cassiliano, 2002). The farthest downstream outcrop that we studied is $3 \mathrm{~km}$ north of the U.S.-Mexico border crossing at San Luis, Arizona (appendix 1, locality 05-87). This exposure is on the southwestern edge of a terrace that is contiguous with the surface called Yuma Mesa (fig. 2B). Yuma Mesa is underlain primarily by sediments of the Chemehuevi Formation, and underlying sediments are cut by the active Algodones Fault, an eastern branch of the San Andreas Fault system (Olmsted and others, 1973).

Although we have primarily studied the formation in the lower Colorado River valley, correlative tributary facies are found in tributary valleys within the Basin and Range geologic province. Remnants of the Chemehuevi Formation have been identified in the lower parts of Las Vegas Wash, the Virgin River, Sacramento Wash, and possibly the Gila and Bill Williams Rivers (Fig. 2A).

\section{Longitudinal Distribution}

In longitudinal profile, the exposures of the Chemehuevi Formation form a wedge-shaped deposit relative to the modern valley profile (fig. 7). The elevation of the base of the formation generally is poorly exposed (see section titled "Base of the Formation," below). However, there is evidence that the formation extends into the subsurface near Yuma (Olmstead and others, 1973; Dickinson and others, 2006). In most places 
with existing subsurface information upstream of Yuma, however, the base of the formation is inferred to be above or not far below the modern flood plain elevation (Metzger and others, 1973, Metzger and Loeltz, 1973; Howard and Malmon, 2007).

The longitudinal profile shows that the exposed thickness of the formation above the historic valley increases in the upstream direction (fig. 7). The maximum height of the formation above the flood plain increases from about $10 \mathrm{~m}$ near Yuma to about $140 \mathrm{~m}$ in eastern Lake Mead. The relative steepness in longitudinal profile of the Chemehuevi Formation has been noted previously (Lee, 1908; Blair, 1996; Lundstrom and others, 2008) and makes it implausible that the entire formation was deposited in a single giant lake, as proposed by Longwell $(1936,1947,1964)$. Instead, as corroborated by sedimentological evidence discussed next, we

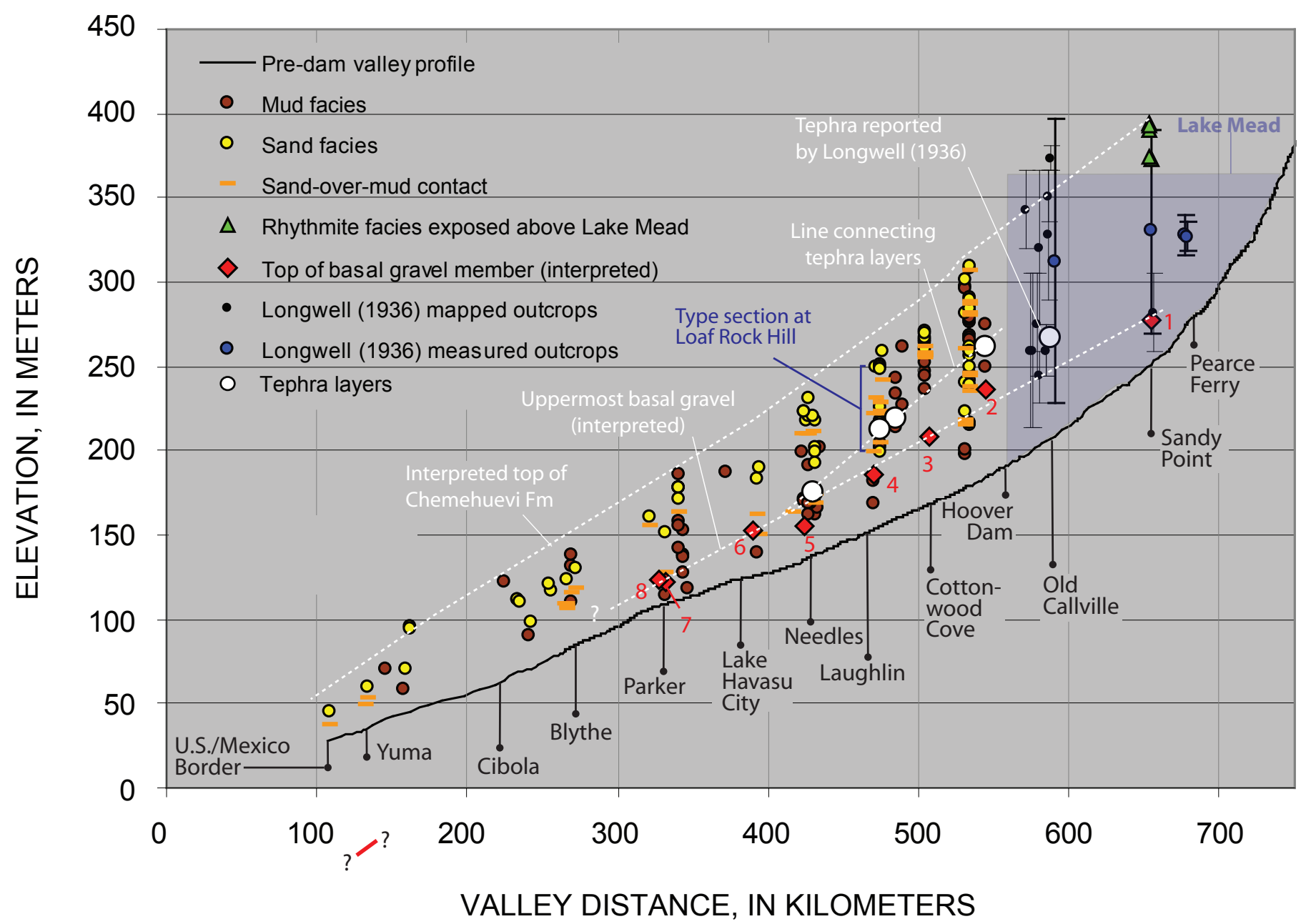

Figure 7. Longitudinal profile of surveyed points within the Chemehuevi Formation between the mouth of Grand Canyon and the United States/Mexico international boundary at San Luis, Ariz. Data shown include points marking highest and lowest local exposures, sandover-mud contacts, tephra layers, top of interpreted basal gravel member, or other points of interest (data in appendix 1). Also shown are the tops and bottoms of outcrops mapped and measured by Longwell (1936), which may have vertical uncertainty as great as $20 \mathrm{~m}$. Numerals in red correspond to labels identifying interpreted basal gravel locations in table 2. Queried slanted red line below horizontal axis marks lowest point on the top of subsurface "coarse gravel unit" of Dickinson and others (2006) along the valley axis, which may relate to the basal gravel member. The valley distance metric is measured along a valley line, rather than a channel line, in order to account for changes in sinuosity over time (see text). Interpreted top of formation, top of basal gravel member, and linear profile connecting tephra localities are shown as dashed white lines. 
A Mouth of Grand Canyon (16.5)

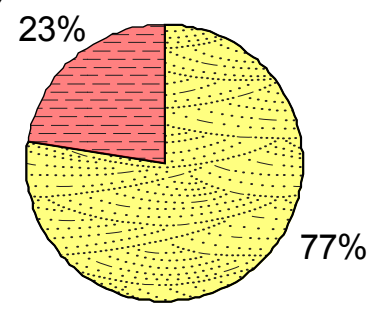

B Pearce Ferry (24.2)

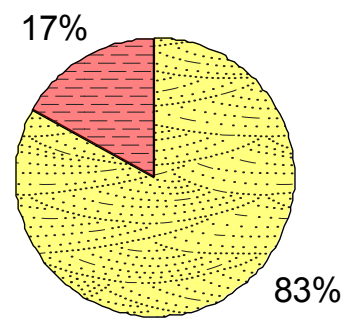

C Old Callville

(136.6) $17 \%$

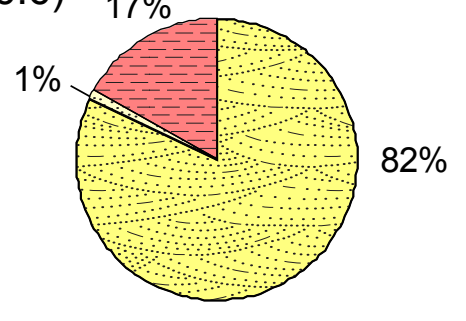

D Loaf Rock (type section) (56.8)

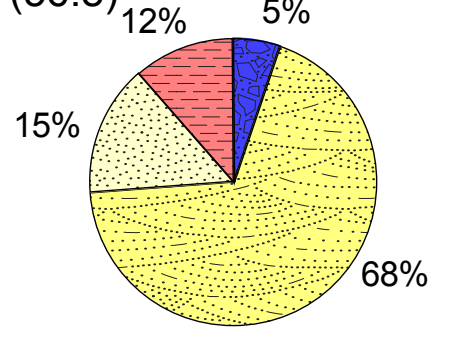

E Katherine Landing (reference section) (18.4)

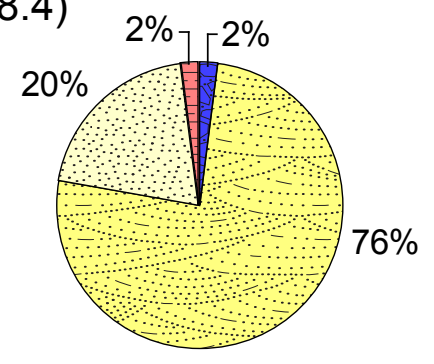

F Near Parker, Ariz. (well LCRP-15)

(33)

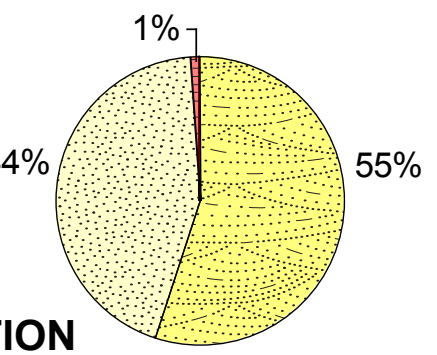

\section{EXPLANATION}

Angular Gravel

Coarse and Medium Sand

Fine and Very Fine Sand

Silt and Clay

Figure 8. Graphical comparison of relative thicknesses of different grain-size classes in measured sections of the Chemehuevi Formation, showing the dominance of coarse and medium sand in the formation. Tabulated data and references for measured sections are listed in table 1. Charts are arranged from upstream $A$ to downstream $F$. Number in parentheses following each label indicates thickness of measured section in meters. This figure does not include the deposit east of River Island (fig. 11A), which includes a $\sim 50$-m-thick sequence almost entirely of medium and coarse sand with two minor intervals of locally derived gravel. 
Table 1. Grain-size proportions by thickness described from the Chemehuevi Formation.

\begin{tabular}{|c|c|c|c|c|c|c|c|}
\hline Site & $\begin{array}{c}\text { Thickness of } \\
\text { Measured } \\
\text { Interval (m) }\end{array}$ & $\begin{array}{c}\text { Angular } \\
\text { Gravel }\end{array}$ & $\begin{array}{l}\text { Coarse } \\
\text { and } \\
\text { Medium } \\
\text { Sand }\end{array}$ & $\begin{array}{c}\text { Fine and } \\
\text { Very Fine } \\
\text { Sand }\end{array}$ & $\begin{array}{c}\text { Silt and } \\
\text { Clay }\end{array}$ & Comments & Reference \\
\hline \multicolumn{8}{|c|}{ Percent of outcrop thickness by dominant grain size class: } \\
\hline $\begin{array}{l}\text { Mouth of Grand Canyon, Nev. } \\
\text { (N. of Colorado River) }\end{array}$ & 16.5 & $0 \%$ & $77 \%$ & $0 \%$ & $23 \%$ & $\begin{array}{l}\text { Longwell only reported a part of the } \\
\text { section }\end{array}$ & $\begin{array}{l}\text { Longwell (1936); } \\
\text { appendix } 6\end{array}$ \\
\hline $\begin{array}{l}\text { Pearce Ferry, Ariz. } \\
\text { (S. of Colorado River) }\end{array}$ & 24.2 & $0 \%$ & $83 \%$ & $0 \%$ & $17 \%$ & Top $37 \mathrm{~m}$ of formation not exposed & $\begin{array}{l}\text { Longwell (1936); } \\
\text { appendix } 6\end{array}$ \\
\hline Katherine Landing, Ariz. & 56.8 & $5 \%$ & $68 \%$ & $15 \%$ & $12 \%$ & $\begin{array}{l}\text { Type section, Loaf Rock; top not } \\
\text { exposed }\end{array}$ & $\begin{array}{l}\text { This study; } \\
\text { appendix } 9\end{array}$ \\
\hline Katherine Landing, Ariz. & 18.4 & $2 \%$ & $76 \%$ & $20 \%$ & $2 \%$ & Reference section, near Lake Mohave & $\begin{array}{l}\text { This study; } \\
\text { appendix } 10\end{array}$ \\
\hline
\end{tabular}

interpret that most of the formation was deposited within an aggrading fluvial system. The trend of thickening towards the north, as depicted in the longitudinal profile (fig. 7), strongly suggests to us that deposition of the Chemehuevi Formation was caused by an increase in sediment supply from upstream, rather than a downstream event such as a natural impoundment or sea level rise.

\section{Sedimentology}

Along the Colorado River corridor, as along all river valleys, deposits of widely differing lithology are complexly interbedded over small spatial scales, so that many facies exist within the same stratigraphic unit. The Chemehuevi Formation is dominated by sand and also includes silt, clay, and gravel (fig. 8; table 1). Within the Chemehuevi Formation, the two most widespread mappable facies are a bluff-forming, well-bedded mud facies, and a poorly exposed gravelly sand facies. The mud and sand facies contain different partice size distributions (fig. 9 and appendix 2), and exhibit distinct differences in bedding, color, sedimentary structures, weathering patterns, and fossil assemblages. Several other facies have also been observed: (1) a thick-bedded rhythmite facies, described as a succession of giant varves by Longwell (1936), most of which is now submerged under Lake Mead; (2) tributary facies, consisting of sediments deposited in major tributary valleys that are traceable to the Chemehuevi deposits in the main Colorado River Valley; and (3) a valley-margin facies that is poorly sorted and poorly bedded. This section describes and illustrates lithologic characteristics of each of the main facies of the formation that have been identified. Interpretations of likely depositional environments for the different facies are discussed in the section titled "Interpretations and Discussion."

\section{Mud Facies}

The mud facies of the Chemehuevi Formation is equivalent to most of unit $\mathrm{D}$ of the older alluviums, in the stratigraphy of Metzger and others (1973). Besides characteristic bedded mud and fine sand, those authors recognized two subfacies within unit D: "(1) a basal gravel overlain by interbedded sand, silt, and clay, and (2) local gravel" (p. $\mathrm{G} 24)$. The basal gravel is discussed further later, as a likely lower member of the formation. The bulk of the mud facies consists of layers of well-bedded sand, silt, and clay (fig. $10 \mathrm{~A}$ ) and is generally tan or pink at the outcrop scale (typical outcrops are very pale orange, 10 YR 8/2). This facies commonly forms steep gullied slopes, bluffs, and badlands. Individual beds vary in thickness from several centimeters to several decimeters and commonly alternate between fine sand and silty clay. The beds are horizontal except in rare instances that show soft sediment deformation or bioturbation and can be traced continuously for tens of meters. In addition to the fine-grained, Colorado River-derived sediment, the mud facies commonly is interbedded with lenses of angular gravel, the grain size and relative proportion of which increase towards the valley margins.

The mud facies commonly consists of alternating horizontal beds dominated by sand or silt and clay, with sharp internal boundaries between the two types of layers (fig. 10B). 
The sandy parts of the couplets typically consist of about 50 percent fine and very fine sand and 50 percent silt-sized grains (fig. 9) and in places exhibit ripple crossbedding (fig. $10 C$ ). By contrast, silt and clay-sized sediment dominate the fine-grained parts of the couplets. In rare cases, unconformable surfaces with amplitudes as high as several meters may be present within the mud facies. The mud facies locally also contains meter-scale laminated sequences of gypsiferous clay (fig. 10D). The gypsum may be expressed as 1 to $10 \mathrm{~cm}$ long secondary selenite crystals littering the regolith on many exposures. In places, clay sequences occur in lenticular bodies 1 to $2 \mathrm{~m}$ thick and as much as 400 $\mathrm{m}$ wide, some of which contain aquatic and other vertebrate fossils (Metzger and others, 1973, p. G25). Additional characteristics of the mud facies include abundant evidence of decayed roots and other plant matter, rare zones of carbonate accumulation (paleosols), and small mollusks and microfossils, which are discussed further in section 7 . Clay mined from the formation, presumably from the mud facies, was used to make the impervious core of Davis Dam (fig. 1B) (Longwell, 1963).

\section{Sand Facies}

The sand facies of the Chemehuevi Formation is approximately equivalent to unit $\mathrm{E}$ of the older alluviums of Metzger and others (1973), who characterized the unit as consisting of both sand deposited by the Colorado River, and gravel deposited by local tributaries. The sand facies includes units mapped by Faulds and others (2004) as the coarse facies of their Chemehuevi alluvium (their $\mathrm{Qcc}_{c}$ ), the coarse facies of their Mohave alluvium $\left(\mathrm{Qcm}_{\mathrm{c}}\right)$, and possibly

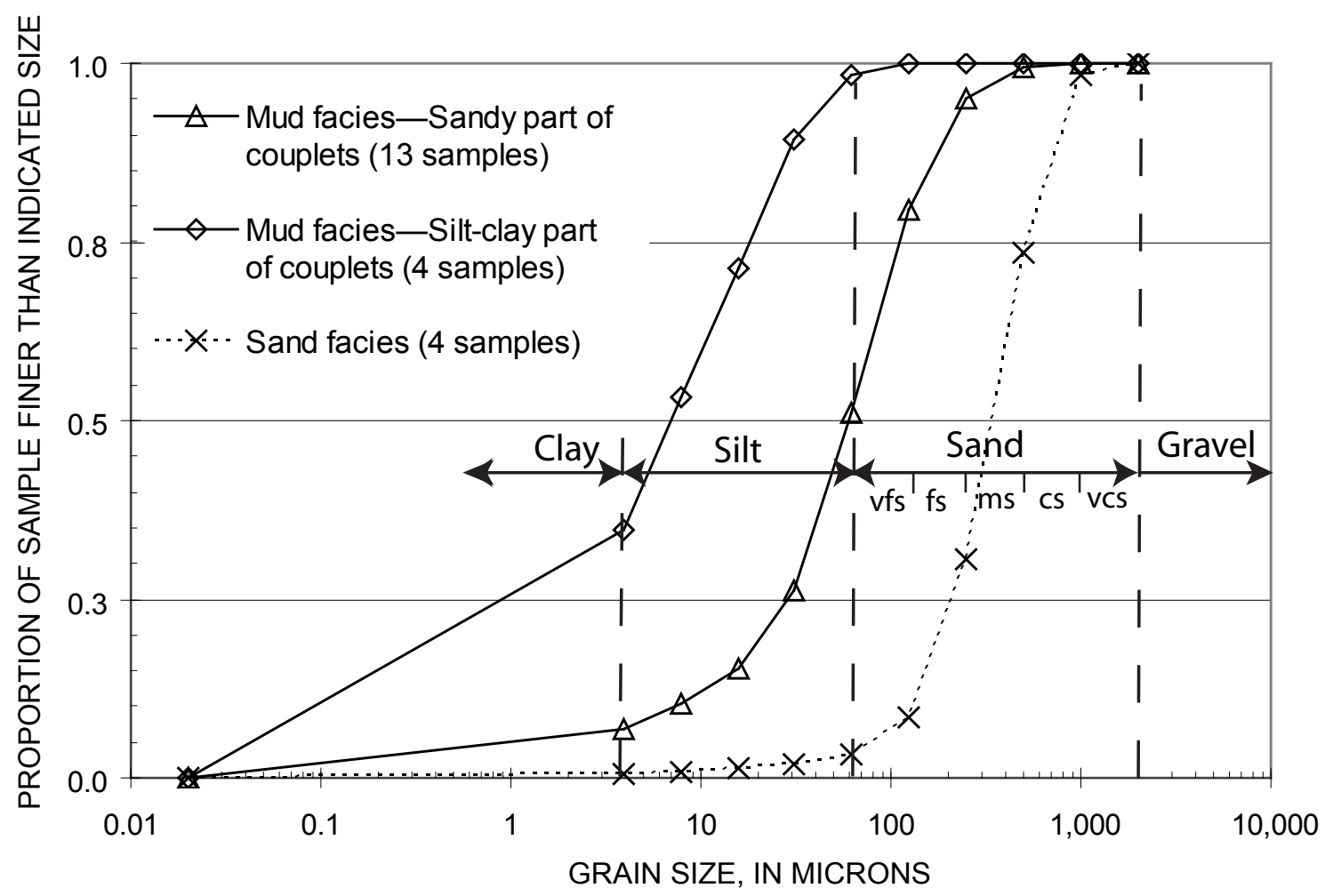

Figure 9. Averaged particle-size data from samples collected from typical beds of the mud and sand facies of the Chemehuevi Formation from outcrops downstream of Parker Dam, Calif., and north of Nelson, Nev. Mud facies in sampled areas are composed dominantly of sand-mud couplets, the two components of which were analyzed separately. Analyses were conducted by M. Kirby at California State University, Fullerton, on samples of sediment suspended in water, using a laser particle size analyzer. Particle size data for all samples are in appendix 2. Abbreviations: vfs, very fine sand $(0.0625$ to $0.125 \mathrm{~mm})$; fs, fine sand $(0.125$ to $0.25 \mathrm{~mm})$; $\mathrm{ms}$, medium sand $(0.25$ to $0.5 \mathrm{~mm})$; cs, coarse sand $(0.5$ to $1 \mathrm{~mm})$; vcs, very coarse sand (1 to $2 \mathrm{~mm})$. Longwell (1963) reported that clay from the formation has a median grain size of 3 microns. 
some of coarser grained occurrences of their Emerald alluvium (Qce) (fig. 5C). This facies is dominated by tan, unconsolidated sand with common crossbedding. The lack of grain cohesion and high degree of sorting results in rounded slopes of loose, dry sand regolith that is commonly wind-reworked, resulting in few well-exposed outcrops (fig. 11A).

The sand facies typically overlies the mud facies, leading to a distinctive two-part stratigraphy of many remnants of the Chemehuevi Formation, in which a slope forming sand facies overlies a bluff-forming mud facies (fig. 1). In some places, angular gravel intervenes between the mud facies and the sand facies. This configuration of sand overlying mud is a distinguishing feature of the Chemehuevi Formation downstream from Lake Mead, and has been frequently noted in the geologic literature (for example, Newberry, 1861; Lee, 1908; Longwell, 1963; Metzger and others, 1973; Blair, 1996). The sand facies has nearly the same areal distribution and elevation range as the mud facies. However, as the sand facies generally overlies the bluff-forming mud facies, the sand facies tends to occupy the most map area throughout the range of the formation.

The sand is well-sorted, with a mode in the medium sand ( 0.25 to $0.5 \mathrm{~mm}$ diameter) range. It contains scattered rounded and angular pebbles and is distinctively coarser than most of the mud facies (fig. 9). The sand particles are subrounded to well rounded and contain a high proportion of rounded quartz grains (fig. 11B). Exposures show a variety of fluvial sedimentary structures, including both ripple and dune-scale crossbedding, as well as horizontally laminated sand (fig. 11C). Also present are low-angle, tabular crossbeds, and rare trough crossbedding with curved bounding surfaces. Rip-up clasts derived from the underlying mud are locally common near the base of the sand facies. The unconsolidated sand is easily reworked by the wind and so provides a source for modern eolian sand that commonly mantles the surface of deposits and extends into nearby areas downwind. Locally the facies may include eolian beds that were reworked by wind during accumulation of the formation.

The sand facies of the Chemehuevi Formation also includes discontinuous beds of imbricated and locally crossbedded, rounded pebble and cobble gravel (especially near the center of the valley), interbedded lenses of locally derived angular gravel, vertical root casts (fig. $11 D$ ), and discontinuous layers of horizontally bedded silt and clay less than $0.5 \mathrm{~m}$ thick (fig. $11 E$ ). Where the tops of sand-facies exposures are relatively uneroded or capped with younger gravel, they contain reddish, pebbly, stage II carbonate soils, consistent with a late Pleistocene age (Machette, 1985) (fig. 11F). In places where the sand facies is not overlain by younger fan gravel or by the younger, inset Colorado River terrace gravels, pebble concentrations on the surface evidence post-depositional wind deflation. We interpret this lag as the result of winnowing by the wind, which would concentrate pebbles at the surface that were originally scattered throughout the deposits.

\section{Rhythmite Facies}

The thickest deposits of the Chemehuevi Formation were described by Longwell (1936) in the area since flooded by Lake Mead (fig. 12; appendix 3). As in downstream examples, the formation as exposed in the Lake Mead area typically included an upper slope-forming, sand-rich interval and an underlying fine-grained, bluff-forming interval (fig. 4). The upper interval described by Longwell (1936) resembles the sand facies downstream of Lake Mead, but has interspersed continuous beds of silt and clay that give it a rhythmic layering, which has not been as widely observed below Hoover Dam. Longwell (1936) described the upper interval in the Lake Mead area as comprising a series of fining-upwards sequences, each consisting of thick sand having an abrupt base and grading up into thinner clay-rich layers. As measured by Longwell in a well-exposed section near Old Callville, the 81-m-thick upper member consists of 6 to 10 sequences of "cross-bedded coarse sand topped by horizontal clay-rich layers" (appendix 4). As described by Longwell (1936), sand constitutes 92 percent of the thickness of this section, and silt and clay make up 8 percent. Uninterrupted sand intervals are as thick as $28 \mathrm{~m}$. This outcrop is discussed further as a reference section in the final section of this report.

The characteristic rhythmic bedding structure of the upper member at Old Callville was observed by Longwell throughout the Lake Mead area, including in the sequences at Sandy Point (fig. 12), where he counted 20 such units. The rhythmically bedded member of the Sandy Point exposure was both overlain and underlain by river gravel (appendix 5). At Pearce Ferry, near the mouth of Grand Canyon (fig. 12), Longwell (1936) photographed and measured similarly rhythmic sections $39 \mathrm{~m}$ thick in which sand units as much as 4. 9 $\mathrm{m}$ thick are separated by thinner $(<1 \mathrm{~m}$ thick) mud intervals (fig. 13a; appendix 6). Longwell (1936) described this bedding structure as resembling "gigantic varves" (p. 1448) and proposed the bedding could be the result of individual floods depositing a sand-dominated load at the head of a lake.

We were able to access two exposures of a rhythmically layered facies above the level of Lake Mead. One is the upper part of the Chemehuevi Formation at Sandy Point, where Longwell (1936) described a sequence $119 \mathrm{~m}$ thick as his varve-like succession above a basal gravel layer (appendix 5). As exposed in 2005, the upper $27 \mathrm{~m}$ of the formation at Sandy Point consists almost entirely of coarse to medium sand, capped by a gravelly cemented paleosol with stage-II carbonate morphology. The sand occurs in beds 1 to $2 \mathrm{~m}$ thick, some of them laminated, some cross-bedded, and some massive and locally containing pebbles (fig. 13B). Minor fine-grained intervals occur as beds 5 to $20 \mathrm{~cm}$ thick of silty clay, limey clay, and fine sand (fig. 13C).

A second exposure above lake level near South Cove, in a protected embayment $1.5 \mathrm{~km}$ southeast of Sandy Point (fig. 13D) was mapped as Chemehuevi Formation by Lucchitta (1966; appendix 1, locality 06-305; Wallace and others, 2005). It consists of a rhythmic series of sand-dominated beds 1 to 
$\boldsymbol{A}$

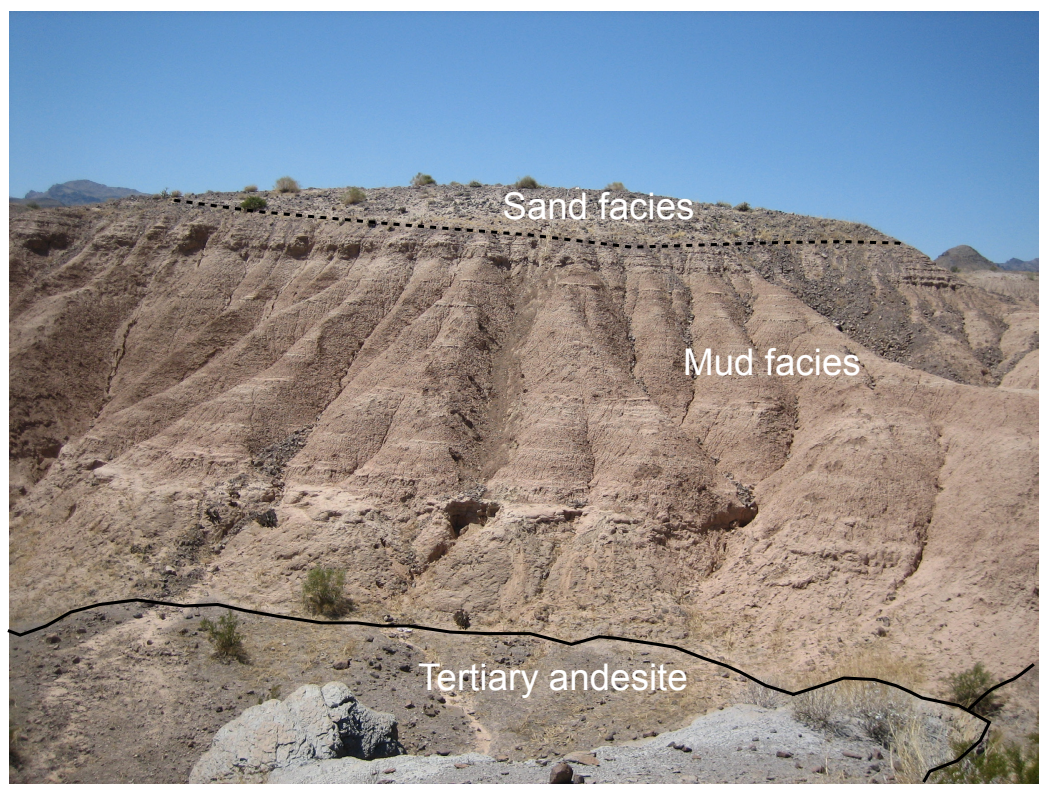

B

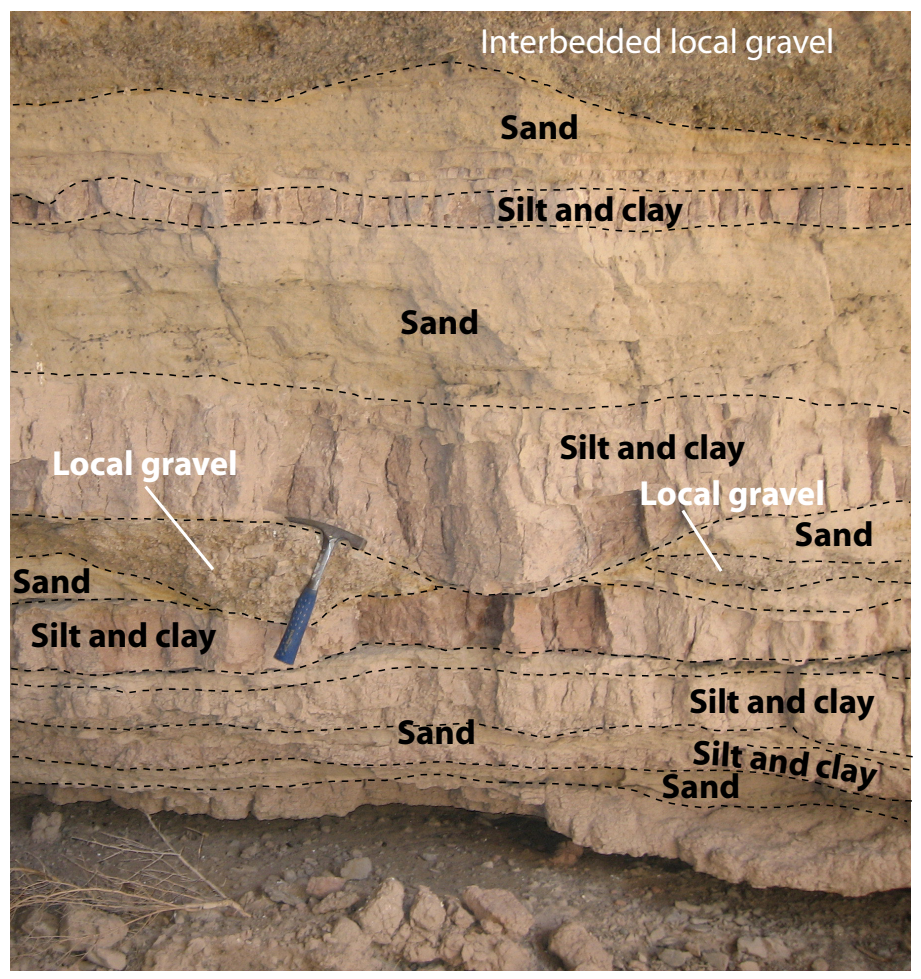

Figure 10. Photographs of the mud facies of the Chemehuevi Formation. $A$, Outcrop-scale photograph north of Nelson, Nev. (Table 1, locality 05-128), showing cliff-forming mud facies beneath sand facies of the formation. Pictured exposure is $19 \mathrm{~m}$ high. A wood fragment found by Blair (1996) in middle of mud facies in this exposure yielded a radiocarbon age of $35.1 \pm 0.4 \mathrm{ka}$. $B$, Bedding characteristics of the mud facies $6 \mathrm{~km}$ southwest of Parker Dam, Calif. (table 1, locality 05-62). Some bedding planes are traced with dashed lines, but not all bedding planes in image are labeled. Hammer is $0.35 \mathrm{~m}$ long. Locally derived angular gravel is labeled as local gravel. $C$, Ripple crossbedding in a bed of medium sand within the mud facies of the Chemehuevi Formation at Katherine Landing reference section (fig. 26, Interval C). $D$, Clay rich sequence of the mud facies north of Nelson, Nev. (appendix 1, locality $05-114$ ). Cliff face exposes $2.75 \mathrm{~m}$ of nearly pure clay. Locally, beds dip 5 degrees east, toward the center of the valley. 


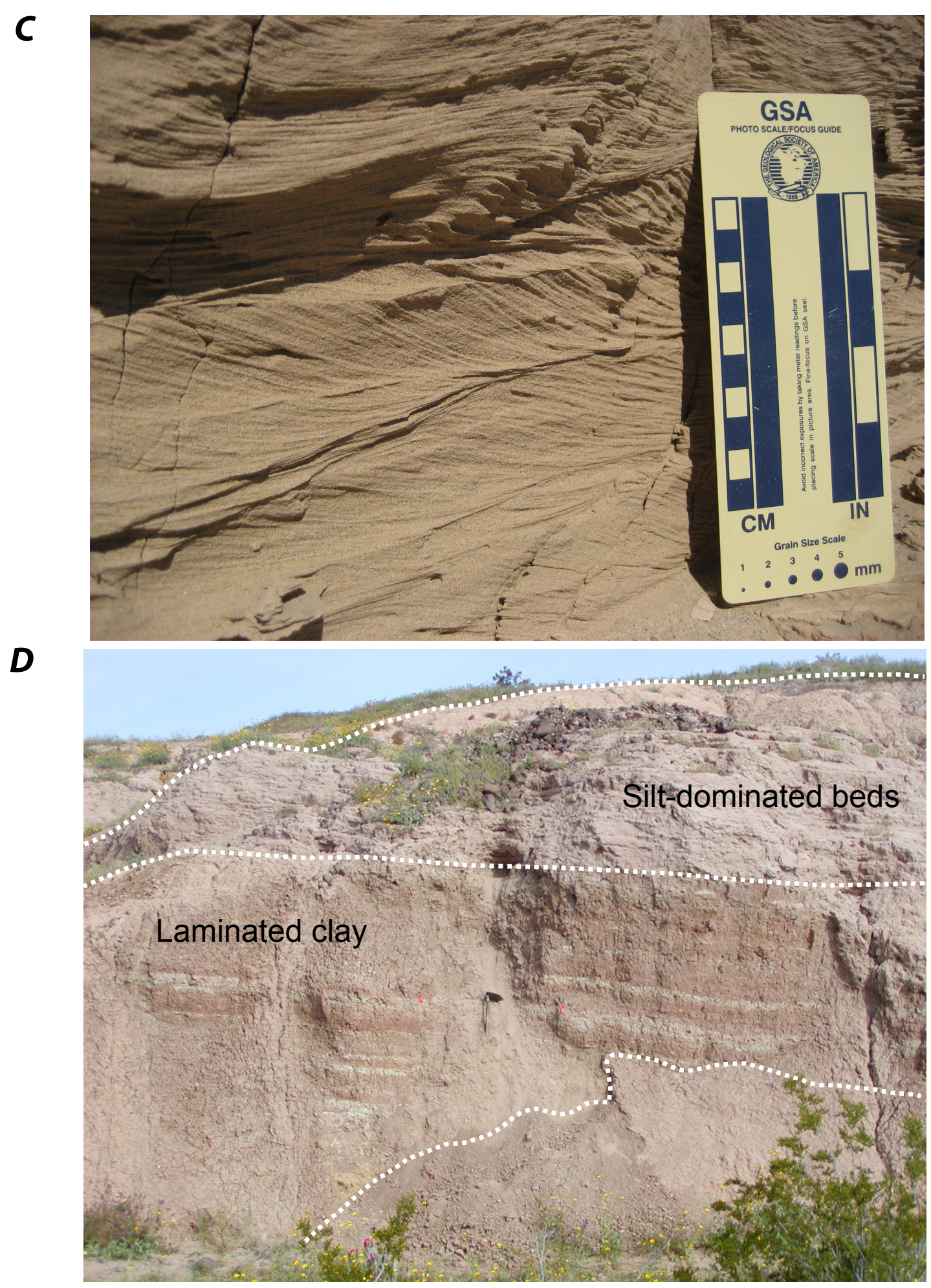

Figure 10.-Continued 
$\boldsymbol{A}$
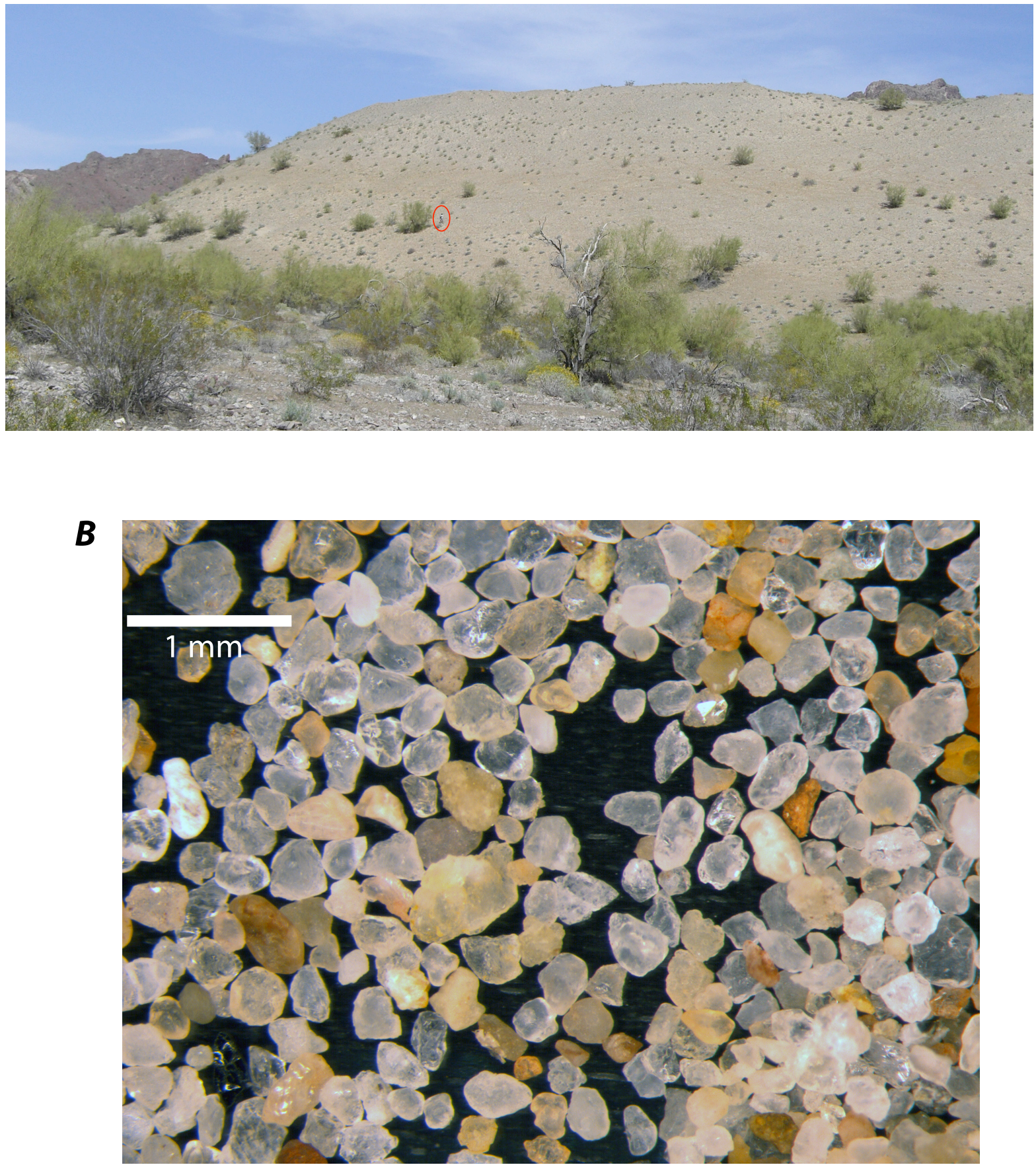

Figure 11. Features of the sand facies of the Chemehuevi Formation. $A$, Photograph of $50-\mathrm{m}$ thick deposit of the sand facies east of River Island, in Topock Gorge, Ariz. Person walking on outcrop (circled in red) is about $2 \mathrm{~m}$ tall. B, Photomicrograph of a sample of the sand facies from type section, near Katherine Landing (appendix 1, locality 07-425-2). $C$, Photograph of horizontal lamination and tabular cross bedding in the sand facies, in an exposure contiguous with the type section near Katherine Landing, Ariz. Mechanical pencil $(10 \mathrm{~cm})$ provides scale. $D$, Calcareous root casts in sand facies near Katherine Landing, Ariz. (appendix 1, locality 07-424-4). Hand lens is $3 \mathrm{~cm}$ long. $E$, Discontinuous layer of silt and clay within the sand facies, south of Davis Dam, near Laughlin, Nev. Mud bed is approximately $0.3 \mathrm{~m}$ thick and extends laterally about $2 \mathrm{~m}$. $F$, Calcic soil with stage II carbonate morphology in rounded gravel that overlies the sand facies north of Nelson, Nev. (appendix 1, locality 06-430-9). Shovel handle is $3 \mathrm{~cm}$ wide. 

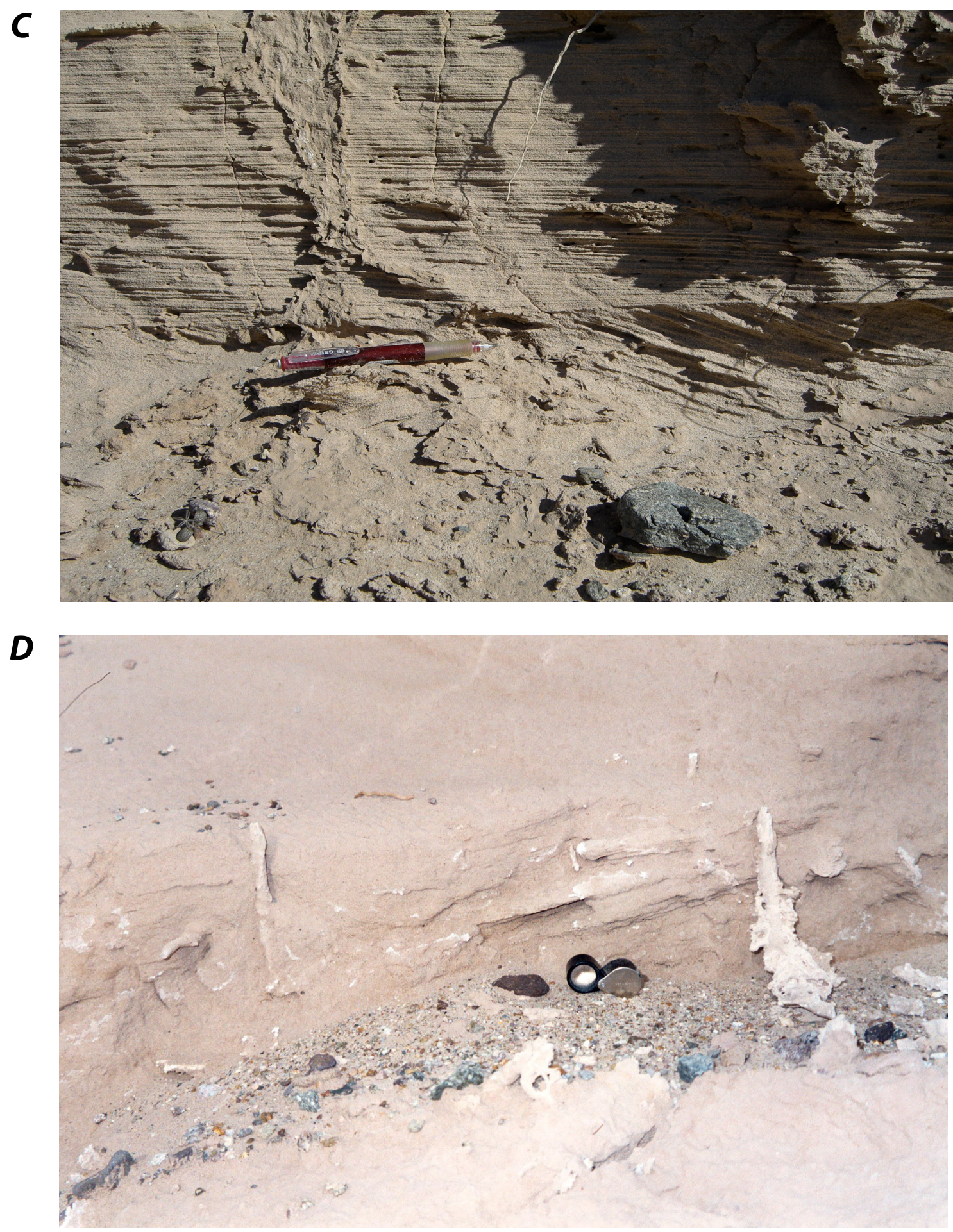

Figure 11.-Continued 
E

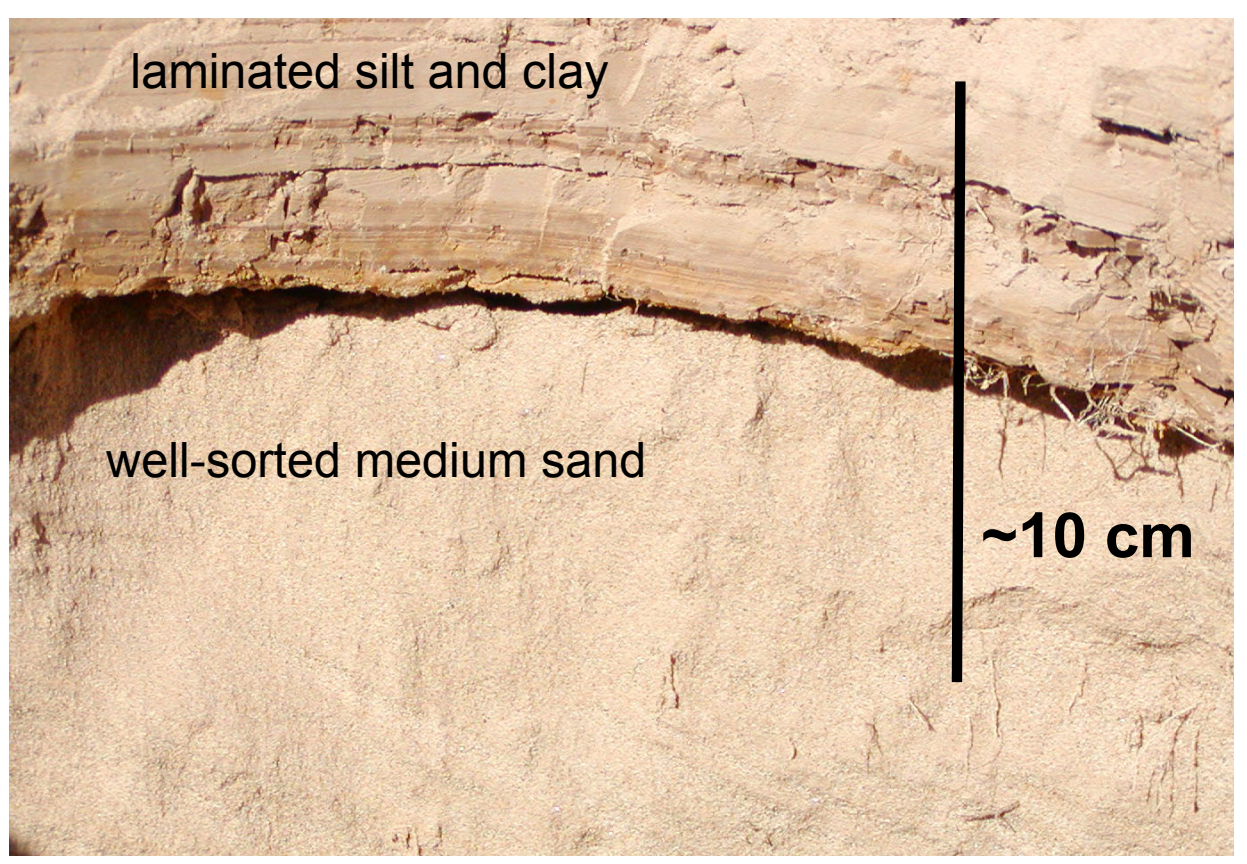

$\boldsymbol{F}$

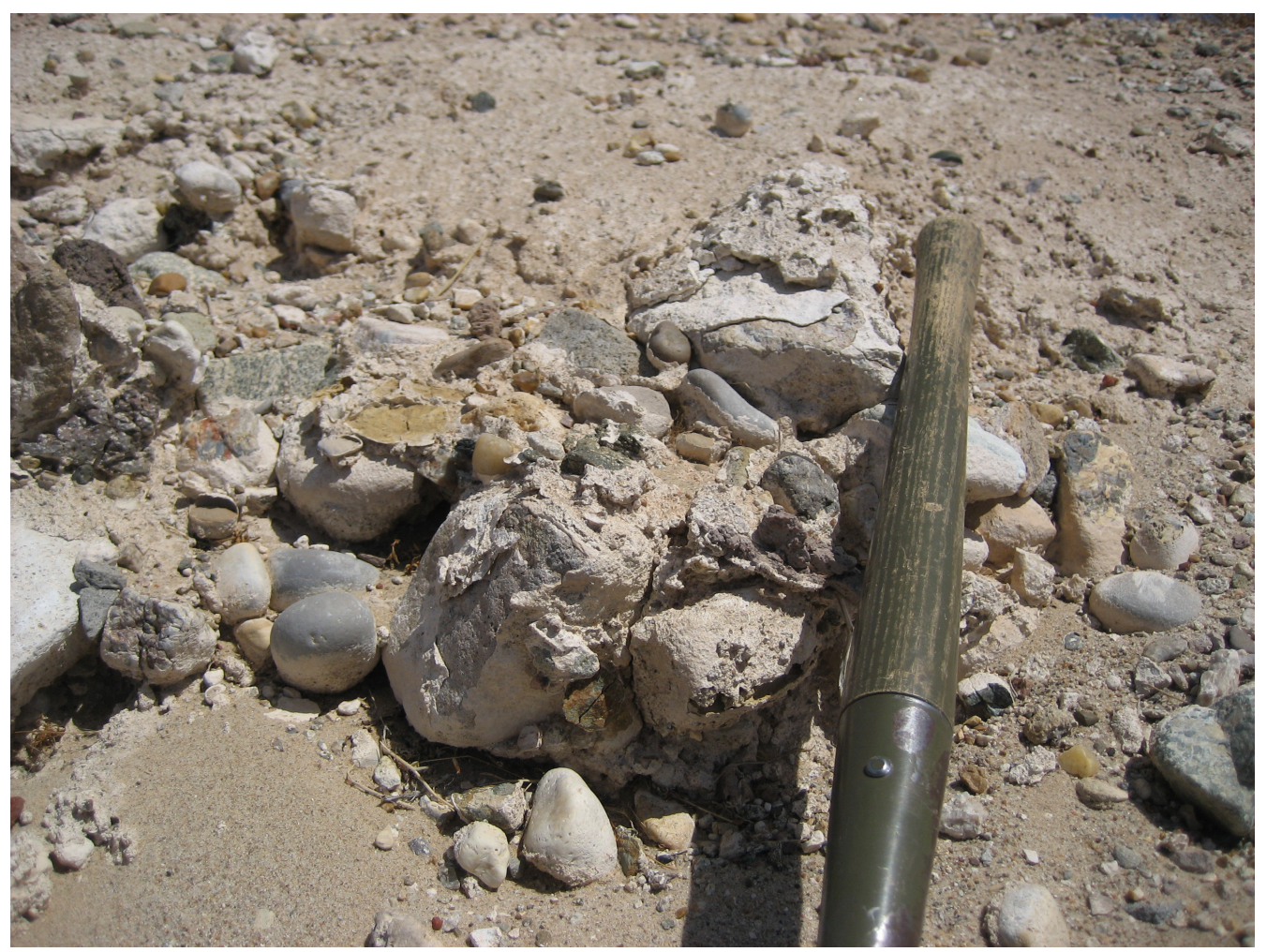

Figure 11.-Continued 
$3 \mathrm{~m}$ thick, each having an abrupt base and fining upward into horizontal beds of laminated clay (fig. 13E). These rhythmic sequences above the high stand of Lake Mead are thinner than at the sections described by Longwell elsewhere in the Lake Mead area, in which individual beds are as thick as tens of meters.

\section{Tributary Facies}

Thick, fine-grained deposits in the lower parts of several large tributary valleys interfinger with and correlate to the Chemehuevi Formation in the main stem Colorado River Valley (Longwell, 1936). We also consider these tributary deposits to be facies of the Chemehuevi Formation.

Longwell $(1936,1960)$ mapped several patches of the Chemehuevi Formation in lower Las Vegas Wash and along the lower Virgin River valley (fig. 12). At least two of the remnants along the lower part of Las Vegas Wash are well exposed above the high stand of Lake Mead (fig. 14A). Longwell (1936) mentioned that these deposits are "exceptionally light-colored" compared with those in the main stem Colorado River valley. We assigned an outcrop-scale color value of 5YR

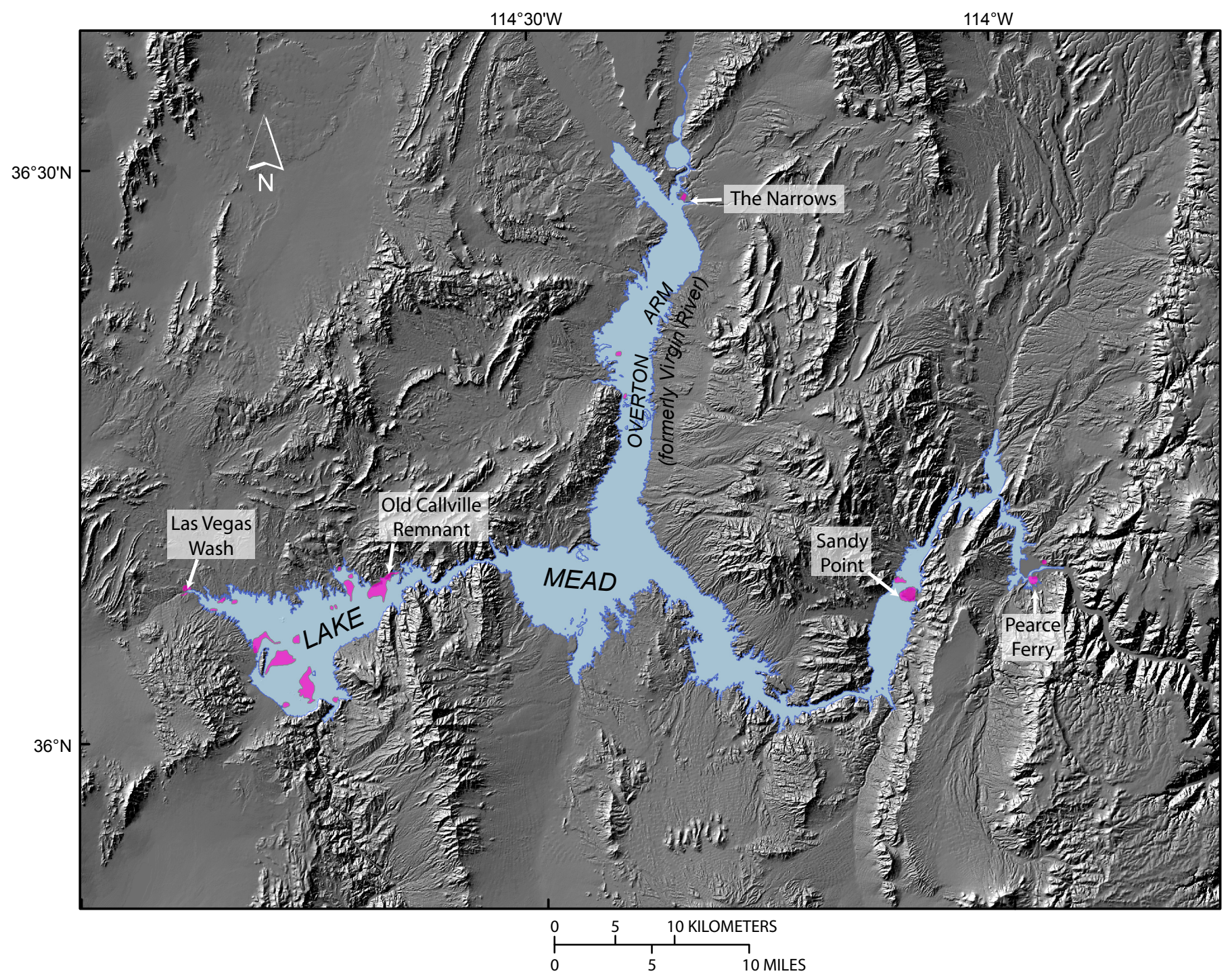

Figure 12. Outcrops of the Chemehuevi Formation in the Lake Mead area, now mostly submerged beneath Lake Mead. Areas shown in pink are those mapped by Longwell (1936) as the Chemehuevis formation. Lake Mead is shown at its maximum capacity ( $375 \mathrm{~m}$ elevation). Place names are exposures referred to in text. 

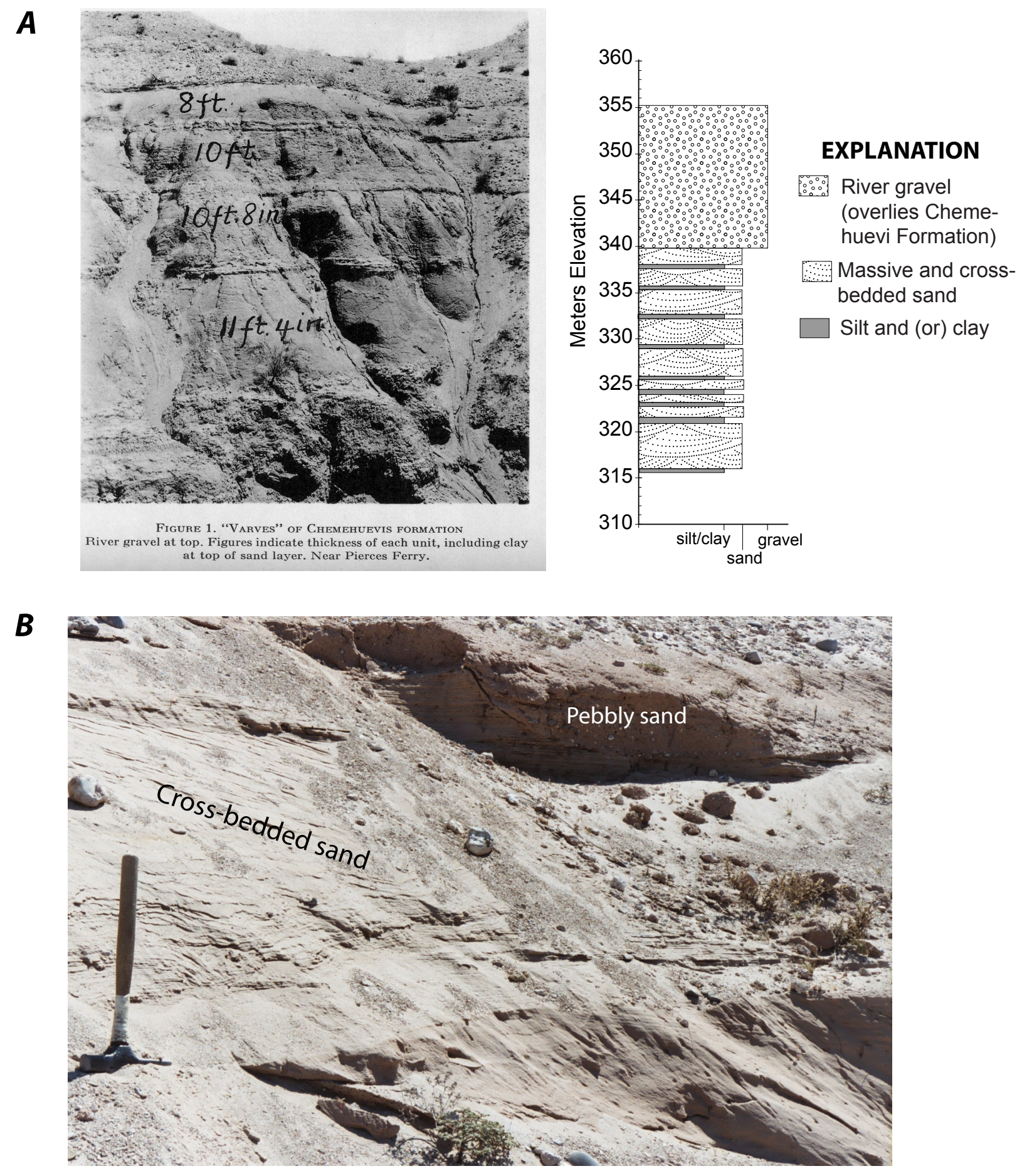

Figure 13. Sedimentary and bedding structures in the rhythmite facies in the Lake Mead area. See figure 12 for locations. $A$, Photograph and graphical measured section from the now-buried Pearce Ferry exposure, reproduced from Longwell (1936). This outcrop is now buried by deltaic sediment. Appendix 6 includes Longwell's measured section of this outcrop and a nearby one across the river. $B$, Laminated and tabular cross bedded sand with curved bounding surfaces in sand interval of the rhythmite facies at Sandy Point, Ariz. Hammer handle is $0.35 \mathrm{~m}$ long. Reddish, partly shaded bed in background is poorly sorted pebbly sand. $C$, Massive sand, silt, and clay layers in wave cut exposure exposed above lake level at Sandy Point, Ariz. (appendix 1, locality 05-145). Shovel is $0.5 \mathrm{~m}$ long. $D$, Outcrop photograph showing rhythmic nature of bedding in a protected embayment near South Cove, Ariz. (appendix 1, locality 06-305). Note similarity in bedding characteristics to the outcrop pictured in figure 13A. Scale varies; outcrop is approximately $10 \mathrm{~m}$ high. $E$, Close up of bedding in an outcrop near the one pictured in $D$, showing horizontally laminated silt and clay layers separated by massive sand bed. Locally derived gravel veneers the exposure. 

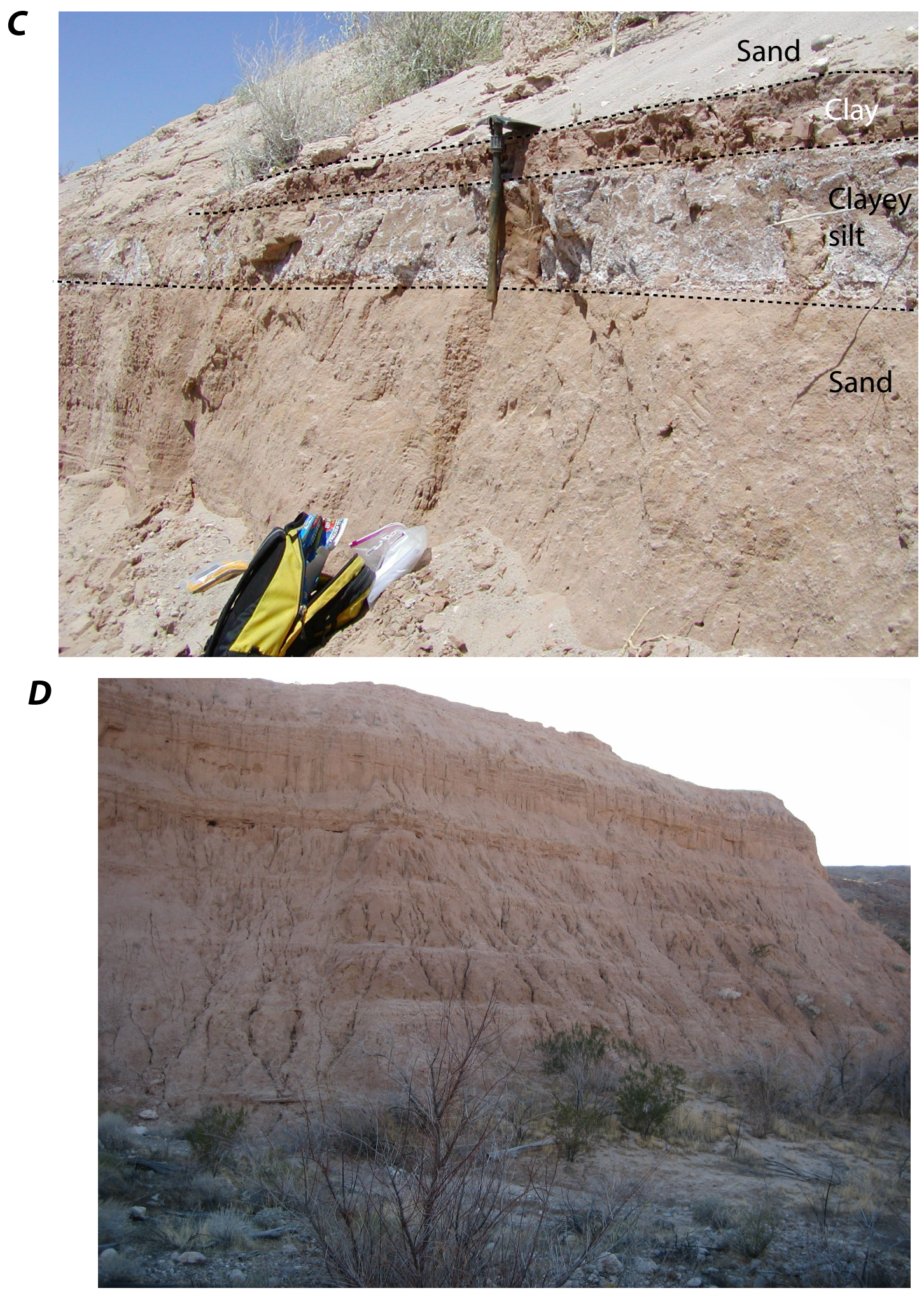

Figure 13. Continued 
$8 / 2$ (pale grayish orange pink) to the exposure in figure $14 a$; this is generally lighter in tone and less orange compared with typical exposures of Chemehuevi Formation along the main stem of the Colorado River. The light color may reflect a scarcity of reddish source rocks in the Las Vegas Wash watershed compared to the Colorado Plateau part of the Colorado River's drainage basin. The exposures of the tributary facies that we have studied in Las Vegas Wash (localites 05-21 and 05-108 in appendix 1) are similar in grain size, degree of consolidation, and bedding characteristics to the mud facies in the main stem Colorado River Valley. No thick deposits of quartz-rich sand (analogous to the sand facies along the main stem) are present in Las Vegas Wash. The fine-grained deposits along Las Vegas Wash interfinger with locally derived angular gravel (Lundstrom and others, 2008).

The Chemehuevi Formation is also exposed in the lower Virgin River Valley. Longwell (1936, p. 1450) stated that these deposits are "less satisfactory for study... because they reflect the influx of much silt derived from the weak Muddy Creek formation" (p. 1450). He noted one deposit northeast of the confluence of the Virgin and Muddy Rivers, just downstream from The Narrows (fig. 12), which partially fills an ancient valley carved into older river gravels, placing it into a stratigraphic position similar to the Chemehuevi Formation in the main Colorado River valley. This deposit is more orange in color (locality $05-216$ is grayish orange, $10 \mathrm{YR} 7 / 4$ ) than the deposits in Las Vegas Wash, and is deposited over as much as $10 \mathrm{~m}$ of erosional topography cut in older, cemented Virgin River gravel (fig. 14B). The deposit consists of a well-bedded, mud-dominated facies that forms bluffs, overlain by slopeforming, poorly exposed, wind-reworked well-sorted sand of fluvial and (or) eolian origin. Similar windblown sand occurs in dune-like deposits along the lower part of the Muddy River valley near the town of Overton, Nev. These sand deposits are significantly reworked by the wind, and we have not determined if they have fluvial bedding structures that could correlate them to the Chemehuevi Formation.

Deposits near the mouth of Sacramento Wash (fig. 1) interfinger with beds of the mud facies of the Chemehuevi Formation (Howard and Malmon, 2007). Like the deposits in lower Las Vegas Wash, these sediments are lighter and more yellow in color (10YR 8/2) than typical exposures of the mud and sand facies along the main Colorado River (fig. $14 C$ ). In outcrop, they are interbedded with fine-grained pale

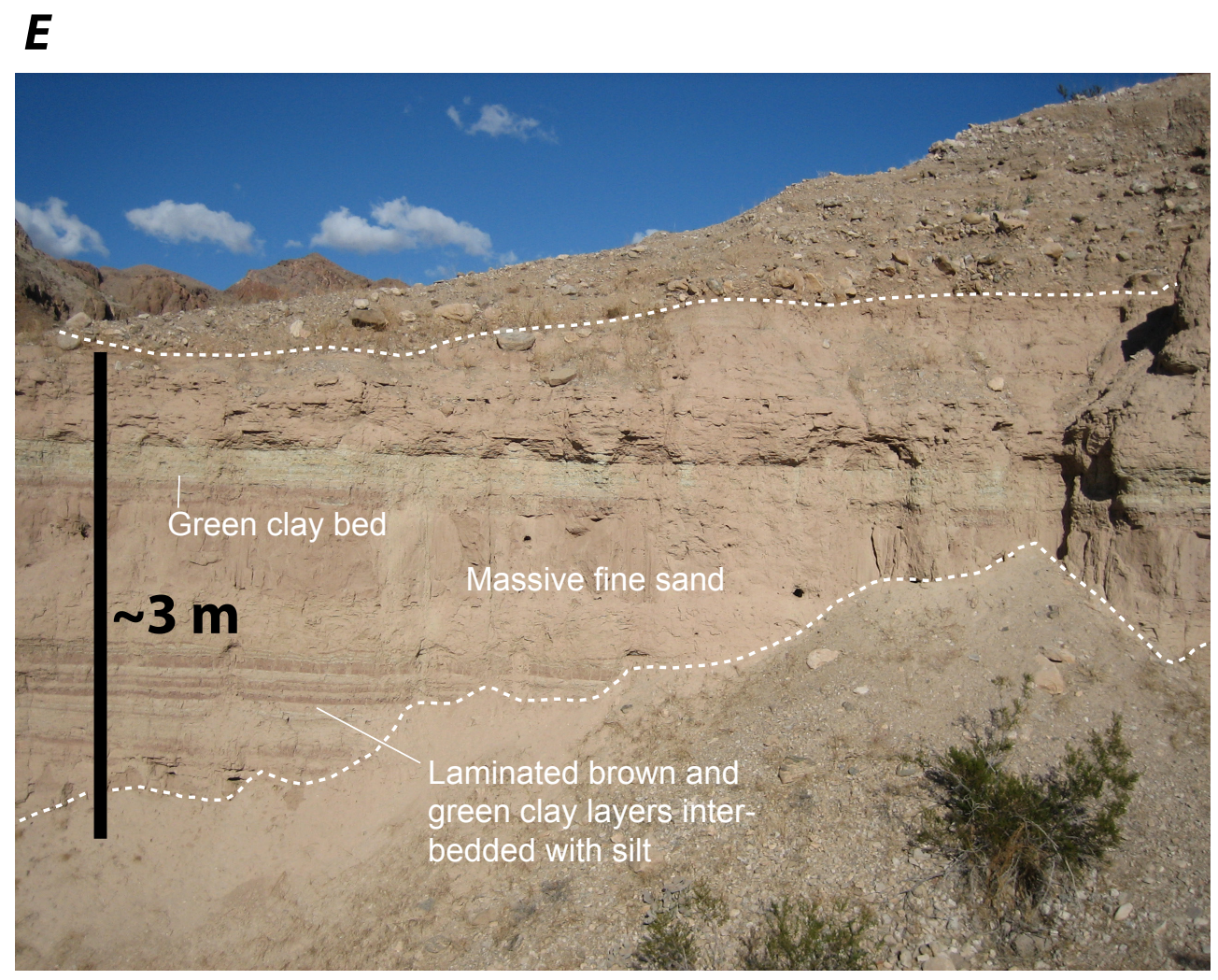

Figure 13. Continued 
A

B
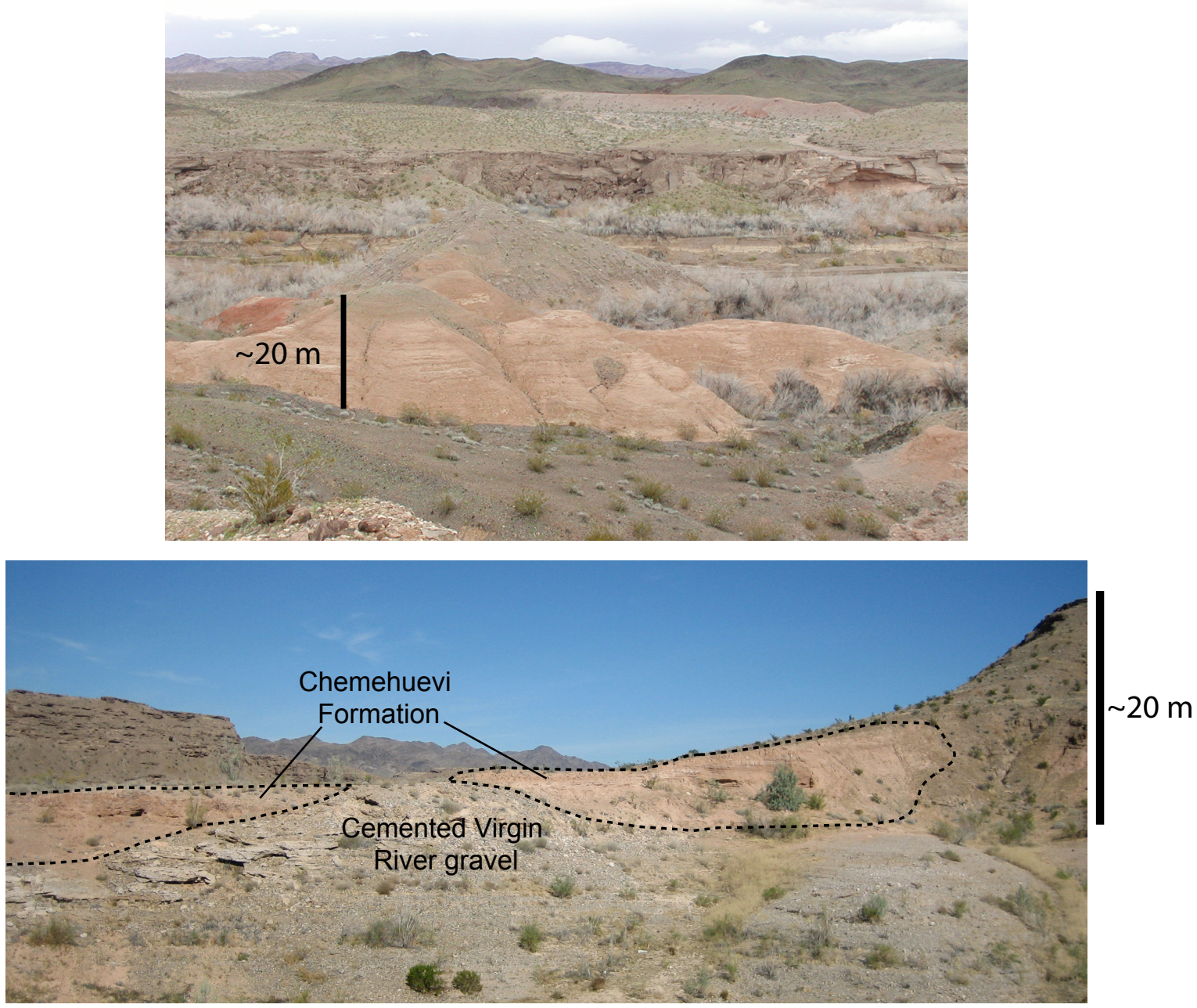

C

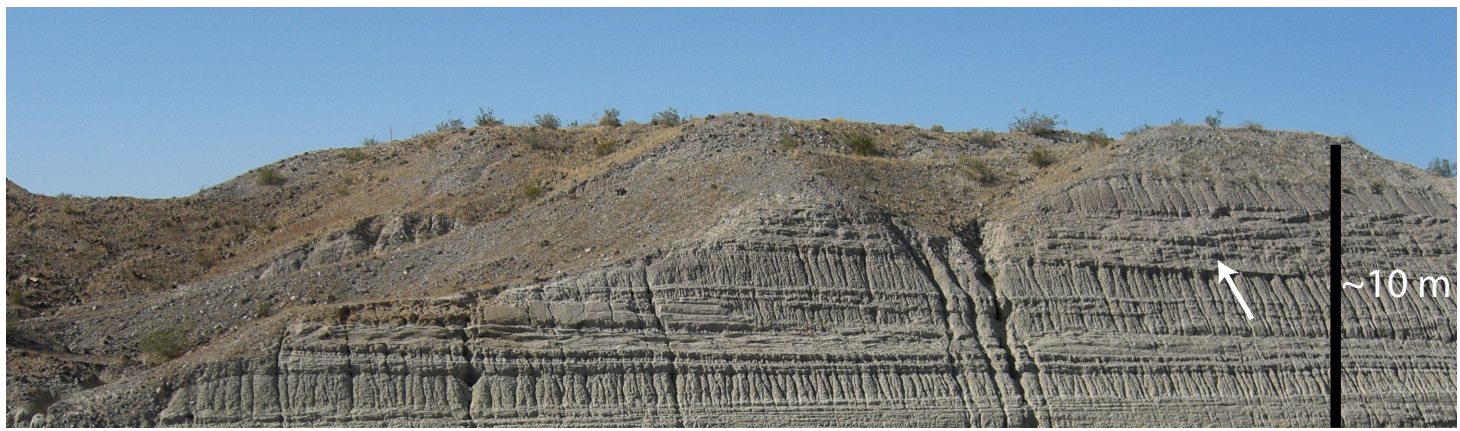

Figure 14. Tributary facies of the Chemehuevi Formation: $A$, Las Vegas Wash, Nev. (light-toned exposure in foreground) (appendix 1, locality 05-21). B, Virgin River, Nev., close to The Narrows. Chemehuevi Formation deposited over erosional topography in older, cemented river gravel (appendix 1, locality 05-210). C, Sacramento Wash, Ariz. Arrow marks lenticular layer in protruding sand beds in roadcut. Roadcut is along I-40 highway near Topock, Ariz. 
orange gray beds that are traceable westward to more typical outcrops of the mud facies of the formation, closer to the axis of Mohave Valley. The surface of the pale deposit along Sacramento Wash is littered with abundant selenite crystals recrystallizing out of gypsiferous clay. The Chemehuevi Formation sediments near the mouth of Sacramento Wash are also notable because they can be traced into valley-marginfacies beds that are locally folded about $2 \mathrm{~km}$ eastward along Sacramento Wash (Howard and Malmon, 2007).

Reconnaissance of small outcrops near the mouths of the Bill Williams and Gila Rivers suggests that the Chemehuevi Formation also exists in these tributary valleys. For example, terraces along the lower Gila River (Wellton Mesa and northeastern Yuma Mesa) have been traced to the large surface - more clearly underlain by the Chemehuevi Formation-on which the city of Yuma, Ariz., now stands (Olmsted and others, 1973, p. H26). We consider thick, fine-grained deposits near the mouths of major tributary valleys within the Basin and Range geologic province to belong to the Chemehuevi Formation, if they can be traced to deposits along the main stem Colorado River.

\section{Valley-Margin Facies}

Poorly bedded fine-sand deposits within the stratigraphic and topographic range of the Chemehuevi Formation are common on the valley margins, interbedded with and overlain by locally derived gravel. For example, deposits on the west side of the valley in Needles, Calif., consist of pinkish, poorly sorted sand (fig. 15). The regular, horizontal bedding structures observed in the mud facies are not as well developed in these deposits, and the sand grains are not so well sorted or rounded as in the sand facies. These sediments are rich in angular, lithic grains, but also contain a component of rounded quartz grains derived from the Colorado River. In the Needles area, deposits of the valley-margin facies are overlain by several meters of locally derived fan gravel (Malmon and others, 2009a). The poorly sorted sand deposits with interbedded angular gravel are more common toward the valley margins than in the center of the valley. We interpret these sediments as having been deposited along the interface between the Colorado River flood plain and local tributary washes and fans during accumulation of the Chemehuevi Formation.

Locally derived angular gravels of pebble to cobble size commonly interfinger with finer grained parts of the formation (for example, fig. 10B). These beds represent deposits along the valley margins but commonly are too small to map separately from the finer grained facies with which they are interbedded.

\section{Structural Deformation}

Field evidence of structural deformation of deposits of the Chemehuevi Formation is rare. At two exposures in the southeast part of Mohave Valley, the mud facies dips $5^{\circ}$ and $15^{\circ}$ toward the east (away from the axis of the valley) (Malmon and others, 2009a). Longwell (1936, p. 1461) stated that thin silt and clay layers in a large remnant of the formation dip 10 to $12^{\circ}$ east (away from the valley) in an area now drowned by the upper part of Lake Mead south of Sandy Point. Both areas are near faults that exhibit Quaternary movement (Pearthree, 1998). Locally faulted beds of the mud facies underlie apparently unfaulted beds of the sand facies north of Lake Havasu City (D. Malmon, unpub. mapping), suggesting possible minor tectonism during deposition of the Chemehuevi Formation. There is evidence that downwarping near the San Andreas Fault system may have deformed the beds underlying Yuma Mesa (fig. 2B), which we interpret as a terrace at the top of, or cut into, the Chemehuevi Formation. Near the U. S.-Mexico border, the top of the mesa decreases southwestward in height relative to the adjacent Colorado River flood plain, suggesting the surface may have been tilted gently southward. In addition, two regionally extensive clay beds beneath the mesa - which were presumably deposited close to horizontally - dip towards the Salton Trough at approximately the same gradient as the modern flood plain (Dickinson and others, 2006).

It is unlikely that the Chemehuevi Formation records broad regional deformation. The gradient of the envelope bounding the top of the Chemehuevi Formation is 50 percent steeper than the historic valley gradient $(0.0006$ versus 0.0004$)$ (fig. 16). Four possibly correlative outcrops of volcanic ash from the Chemehuevi section below Lake Mead record a paleovalley gradient that slopes even more steeply $(0.0007)$ (the stratigraphic context, geochemistry, and likely ages of these tephra layers are discussed in detail later). If the differences in gradient shown in figure 16 were to be explained by tectonism alone, the beds at Sandy Point would have been uplifted more than $100 \mathrm{~m}$ relative to the beds at Yuma during the late Pleistocene, requiring an average uplift rate of $>1$ $\mathrm{mm} / \mathrm{yr}$. In addition, the estimated thickness of the Chemehuevi Formation generally increases upstream, which suggests that aggradation resulted in an increased river gradient. The rarity of deformational features in the formation and the lack of other evidence for such a high regional uplift rate suggest to us that the increased steepness mostly reflects a difference in depositional gradient, rather than broad northeastward upwarping of the Chemehuevi Formation.

\section{Members and Marker Horizons}

\section{Basal Gravel Member}

In a number of locations, the mud and sand facies of the Chemehuevi Formation are directly underlain by layers of Colorado River gravel. Some of these deposits may be conformable beneath the finer grained beds that make up the bulk of the unit and constitute the regionwide basal gravel member implied by Metzger and others (1973). Table 2 lists 
some locations throughout the valley that we believe are possible candidates for being part of a basal gravel member of the Chemehuevi Formation. These sites represent localities where known Colorado River gravels underlie, or are inferred to have underlain, deposits correlated to the Chemehuevi Formation. None of these sites has been definitively demonstrated to be part of a Chemehuevi Formation basal gravel member on the basis of fossil evidence or direct dating. Some of these localities are exposures that are currently accessible, and others are known from records of drill cuttings and of outcrops that are now submerged beneath large reservoirs. The number of candidate examples, as well their relatively smooth longitudinal profile (fig. 7), lead us to conclude that at least some of the following examples constitute a basal gravel member of the Chemehuevi Formation.

Newberry's (in Ives, 1861) discovery of a mammoth tooth was in a bed of fluvial gravel beneath a two-fold succession of mud and overlying sand (fig. 3) that Lee (1908) later recognized as typical of his Chemehuevis unit. Much of this outcrop, including the gravel bed containing the tooth, is now below the surface of Lake Mohave and not accessible. However, Newberry described the bed containing the tooth as being indurated, with calcium carbonate cement. Because most of the exposed Chemehuevi Formation is not cemented, we suspect that the bed containing the tooth may be part of an older deposit underlying the formation, rather than being part of a basal gravel member of the Chemehuevi Formation.

Longwell (1936, p. 1448) described the basal 10 to 12 $\mathrm{m}$ of a 120-m-thick section of the formation in eastern Lake Mead (Sandy Point) as consisting "chiefly of river gravel" (appendix 5). Most of this section, including that gravel member, is now submerged under Lake Mead. According to Longwell's description, the entire deposit occupies a paleovalley of the river cut into older gravels. Because Longwell distinguished older, cemented and deformed river gravel from his Chemehuevis formation, but included the gravel at the base of the Sandy Point section, it is likely that the gravel he described at Sandy Point is conformable beneath the overlying finer grained sequence and is part of a basal gravel member of the Chemehuevi Formation.

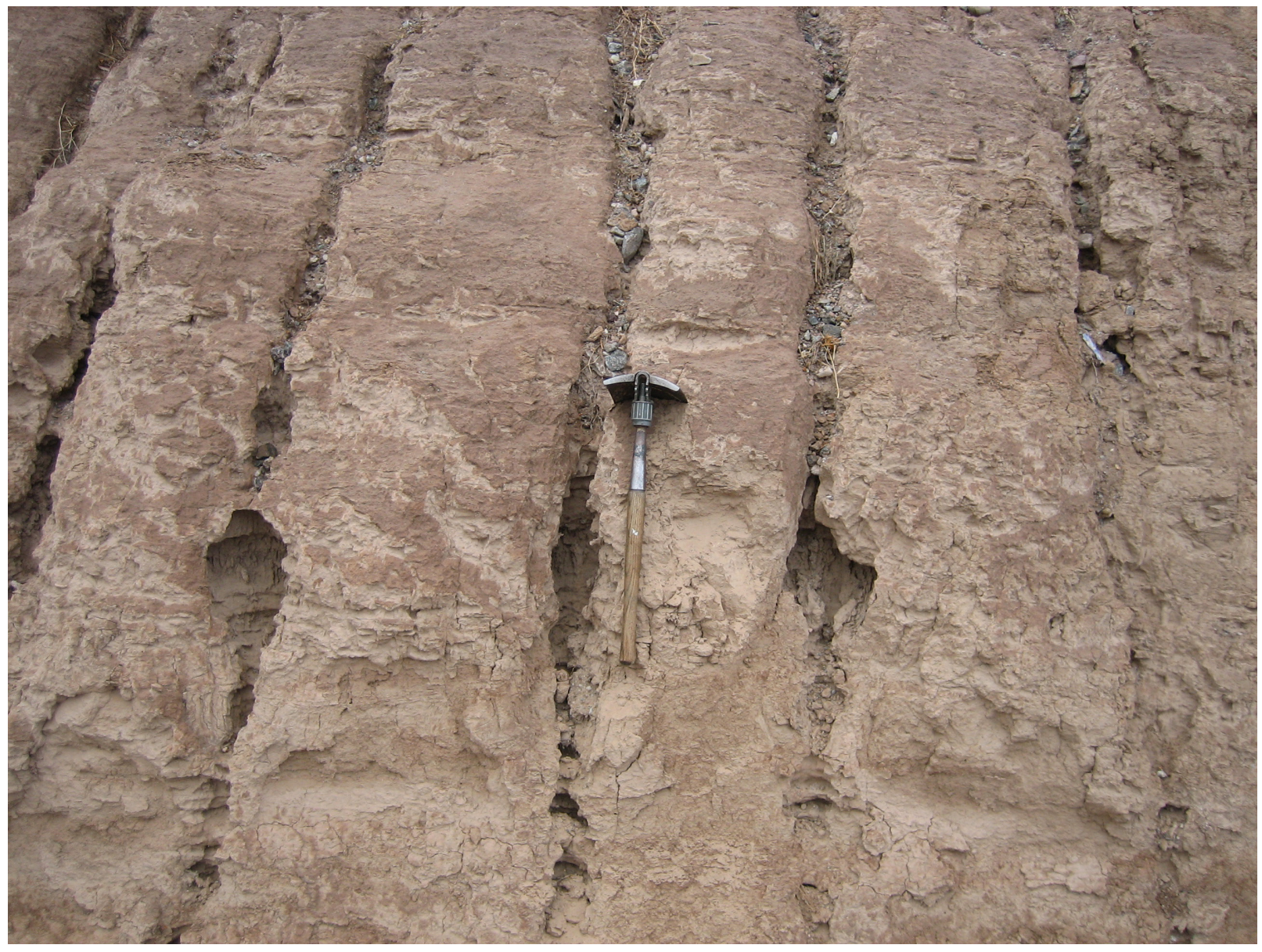

Figure 15. Photograph of poorly bedded, lithic-rich valley-marginal facies next to Denny's restaurant in downtown Needles, Calif. (appendix 1, locality 06-322). Shovel is $0.5 \mathrm{~m}$ long. 
A basal gravel was also reported to exist close to the elevation of the modern flood plain near Parker, Ariz., by Metzger and others (1973, p. G24), based on the interpretation of drill cuttings from well LCRP 15. Metzger and others (1973b) included $27 \mathrm{~m}$ of mostly gravel and sand (including a $1.5 \mathrm{~m}$ thick interval of clay) as the lower part of their units $\mathrm{D}$ and $\mathrm{E}$, below $32 \mathrm{~m}$ of finer grained deposits more typical of the Chemehuevi Formation where it is exposed at the surface (appendix 7). The basal gravel - which was recognized because it directly overlies distinctive blue clays of the late Miocene to Pliocene Bouse Formation (appendix 7) —was described as subrounded to well rounded gravel with clasts as large as $28 \mathrm{~cm}$ in diameter, clay balls, and 10 to 30 percent sand. Metzger and others (1973b) interpreted this basal gravel as riverlaid before the deposition of the finer grained part of their unit D, but they recognized that the lowest $16 \mathrm{~m}$ could be an older unit. At a nearby well, LCRP-21, Metzger and others (1973b) assigned $26 \mathrm{~m}$ of gravel, including rounded gravel as coarse as $30 \mathrm{~cm}$ and clayballs, to their unit D, which also includes $20 \mathrm{~m}$ of overlying sand and silt. Clayballs are common in gravels known to be much older than the Chemehuevi Formation. Thus, it is possible that part of the gravels interpreted as a basal gravel member may not be part of the Chemehuevi Formation. However, because the gravel directly underlies the Chemehuevi Formation as exposed at the surface, it also seems possible that part of the gravel in the drill cuttings may belong to a basal gravel member of the Chemehuevi Formation.

Currently accessible outcrops near the level of the modern flood plain have been tentatively identified from just below Lake Mead to as far downstream as far as Parker, Arizona. In Cottonwood, Mohave, Chemehuevi, and Parker Valleys, uncemented fluvial gravels have been found to underlie the Chemehuevi Formation in bluffs bordering the modern flood plain (fig. 17). At many of these sites, noncemented fluvial gravel beds abruptly underlie the mud facies of the Chemehuevi Formation with no perceptible carbonate soil formation on the uppermost gravel clasts. In addition, the contact between the underlying gravel and overlying fines is nearly flat, with little vertical relief over tens of meters, suggesting little to no erosion of the underlying gravel before deposition of fines.

Lundstrom and others (2008, their fig. 3) reported a basal lag gravel underlying the mud facies in Cottonwood Valley.

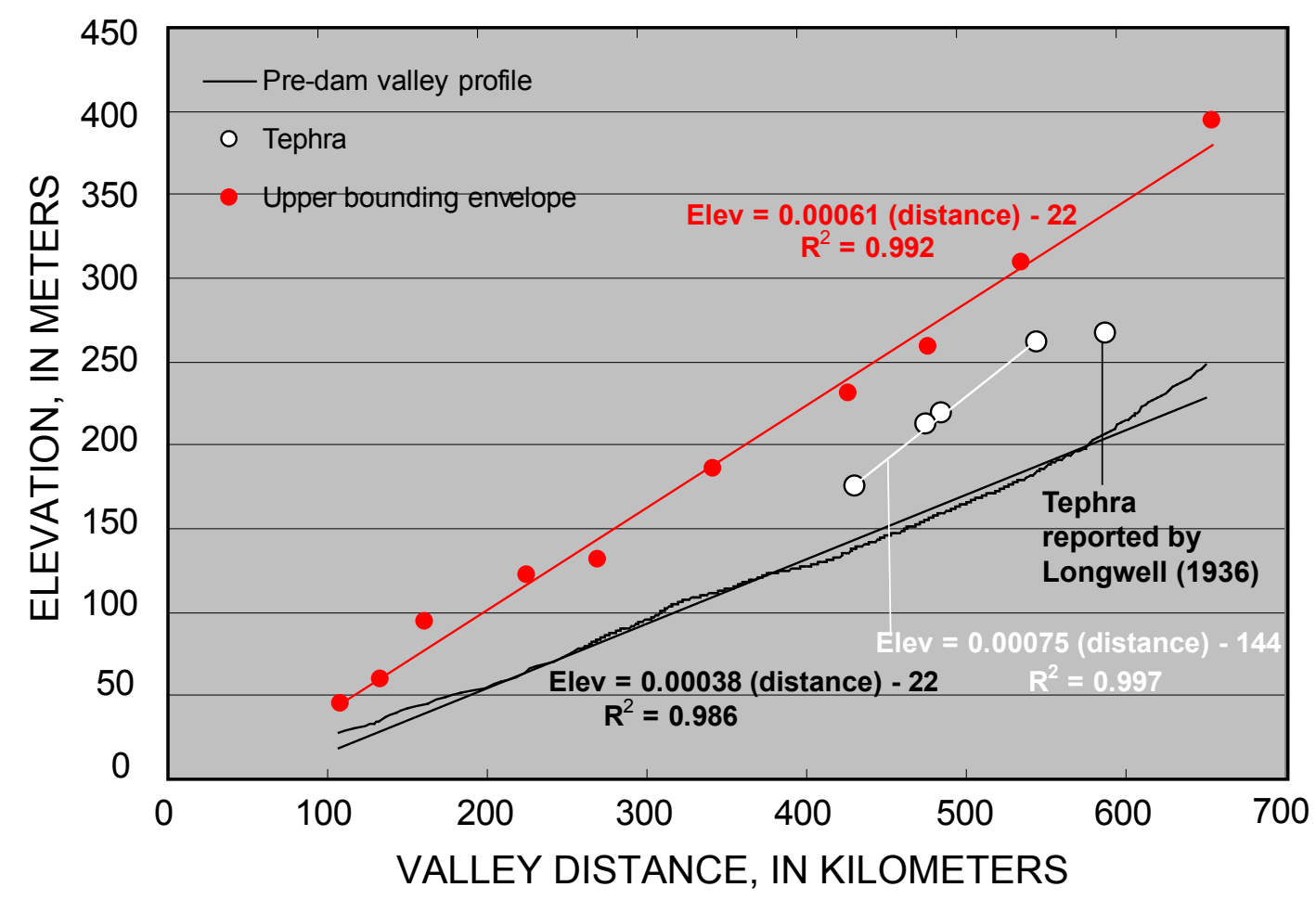

Figure 16. Comparison of valley gradients of the pre-dam valley profile (black, 0.0004 ) with the gradients implied by the upper envelope of the Chemehuevi Formation (red, 0.0006) and the tephra layers in the formation (white, 0.0007). Gradient of the valley floor at peak aggradation was approximately 50 percent steeper than the historical (pre-dam) valley. Tephra layer reported by Longwell (1936) now submerged under Lake Mead (see figure 7) is not included in regression. 
Table 2. Possible locations of basal gravel member of the Chemehuevi Formation.

\begin{tabular}{|c|c|c|c|c|c|c|c|}
\hline $\begin{array}{l}\text { Number } \\
\text { Label in } \\
\text { Fig. } 7^{1}\end{array}$ & Locality Index ${ }^{2}$ & Location and Notes & 7.5' Quadrangle & $\begin{array}{c}\text { Valley } \\
\text { Distance } \\
(\mathbf{k m})\end{array}$ & $\begin{array}{l}\text { Elevation of } \\
\text { Base of } \\
\text { Gravel (m) }\end{array}$ & $\begin{array}{l}\text { Elevation of } \\
\text { Top of } \\
\text { Gravel }(m) \\
\end{array}$ & Data Source and Description \\
\hline 1 & $05-145$ & Sandy Point, Ariz. & Meadview North & 655 & & 277 & $\begin{array}{l}\text { Longwell (1936); lowest member of Sandy Point outcrop (now } \\
\text { submerged below Lake Mead); " } 20 \text { to } 40 \text { feet at the base of } \\
\text { the deposit consists chiefly of river gravel." Elevation of top } \\
\text { of interval inferred from text description of Sandy Point } \\
\text { section by Longwell (1936, p. 1448). }\end{array}$ \\
\hline 2 & N/A & Monkey Hole, Nev. & Willow Beach & 545 & 228 & 238 & $\begin{array}{l}\text { Lundstrom and others (2008, p. } 423 \text { ); "Boulder beds of } \\
\text { Monkey Hole"; river gravel as much as } 10 \mathrm{~m} \text { thick in Colorado } \\
\text { River paleovalley; contains a boulder layer in middle; may } \\
\text { not be part of Chemehuevi Fm. Elevation of top estimated in } \\
\text { field from topographic map by Lundstrom and others (2008). }\end{array}$ \\
\hline 3 & N/A & South of Cottonwood Cove, Nev. & Spirit Mtn NW & 505 & & 208 & $\begin{array}{l}\text { P.K. House, unpub. mapping; flat-lying Colorado River gravel } \\
\text { with nearly horizontal upper boundary near Lake Mohave; } \\
\text { conformably? underlies Chemehuevi Formation. Elevation of } \\
\text { top estimated in field from topographic map. }\end{array}$ \\
\hline 4 & $08-320-2$ & $\begin{array}{l}\text { Arroyo wall east of Laughlin } \\
\text { powerplant, Nev. }\end{array}$ & Davis Dam & 470 & & 186 & $\begin{array}{l}\text { Faulds and others (2004); laterally extensive uncemented river } \\
\text { gravel as thick as } 10 \mathrm{~m} \text { underlying mud facies of Chemehuevi } \\
\text { Formation. Elevation from post-processed GPS data. }\end{array}$ \\
\hline 5 & 07-1008-1 & $\begin{array}{l}\text { Along railroad trestle cut south of } \\
\text { Needles, Calif. }\end{array}$ & Needles & 424 & & 155 & $\begin{array}{l}\text { Malmon and others (2009a); uncemented southward } \\
\text { imbricated river gravel as thick as } 10 \mathrm{~m} \text { underlying mud facies } \\
\text { of the Chemehuevi Formation. Elevation of top estimated } \\
\text { from geologic map (near } 500 \mathrm{ft} \text { contour). }\end{array}$ \\
\hline 6 & 08-1023-2 & N. of Havasu Lake, Calif. & Castle Rock & 390 & & 152 & $\begin{array}{l}\text { This study; laterally extensive uncemented river gravel } \\
\text { underlying wide strath terrace; mud and sand facies inferred to } \\
\text { have been mostly eroded during strath formation; river gravel } \\
\text { as thick as } 10 \mathrm{~m} \text {. Elevation estimate based on highest contour } \\
(500 \mathrm{ft}) \text { on strath terrace surface. }\end{array}$ \\
\hline 7 & $06-230$ & $3 \mathrm{~km} \mathrm{NE}$ of Parker, Ariz. & Parker & 332 & & 122 & $\begin{array}{l}\text { This study; laterally continuous uncemented river gravel at } \\
\text { least } 8 \mathrm{~m} \text { thick underlying } 1 \text { to } 2 \mathrm{~m} \text { layer of Colorado River } \\
\text { silt and sand. Elevation estimated in field from topographic } \\
\text { map. }\end{array}$ \\
\hline 8 & $\mathrm{~N} / \mathrm{A}$ & Well LCRP-15, near Parker, Ariz. & Parker & 328 & 93 & 123 & $\begin{array}{l}\text { Metzger and others (1973; p. G125); lithologic log of well } \\
\text { LCRP-15 in Parker mesa; top of } 42 \text { to } 99 \mathrm{ft} \text { thick river gravel } \\
\text { interval in subsurface from well log descriptions; elevation of } \\
\text { well head ( } 505 \mathrm{ft} \text { ) read from topographic quadrangle. }\end{array}$ \\
\hline
\end{tabular}

${ }_{1}^{1}$ Outcrop number as labeled on longitudinal profile (fig. 7).

${ }^{2}$ Locality index in appendix 2, if applicable.

${ }^{3}$ Distance from Gulf of California as measured along valley line (explained in text). 
They also speculated that $8 \mathrm{~m}$ of rounded boulder and cobble gravel in a paleovalley cut into Miocene rocks near Monkey Hole may relate to the base of the fine-grained (Chemehuevi Formation) sequence, but at that site it is not overlain by any fine grained beds. The examples mentioned by Lundstrom and others (2008) both plot above the trend of the line connecting the other possible examples of the basal gravel member (points 2 and 3 in fig. 7) and may not be related to it. A likely basal gravel member of the Chemehuevi Formation has also been identified in various locations between Cottonwood Cove and Laughlin, Nev. (fig. 2B). In one location near Cottonwood Cove, the mud facies of the formation is directly underlain by at least $5 \mathrm{~m}$ of rounded river gravel with a flat upper boundary that can be traced for tens of meters.

Near the upstream end of Mohave Valley, a possible basal gravel member underlying a mud-rich facies of the Chemehuevi Formation (K. House, unpub. mapping) is widespread locally, has a near-horizontal upper boundary, and appears to be conformable with the overlying sand and mud-dominated sediments that we assign to the Chemehuevi Formation (fig. $17 A$ ). In bluffs at the western boundary of the modern flood plain south of Needles, Calif., Malmon and others (2009) mapped river gravel as thick as $10 \mathrm{~m}$ near the modern flood plain elevation, abruptly overlain by finer grained deposits identified as the Chemehuevi Formation. In Chemehuevi Valley, a widespread, mostly uncemented fluvial gravel deposit near Havasu Lake, Calif. (fig. 2B) forms a large flat, undissected surface about $5 \mathrm{~km}$ long. This surface is not clearly overlain by beds identifiable as the Chemehuevi Formation but is interpreted to have been exposed after erosion of overlying finer grained, less resistant beds. Vertebrate fossil remains including fish skeletons have been reported from this deposit (G. Parras, Chemehuevi Indian Tribe, oral commun., 2009). Near the flood plain surface around Parker, Arizona (fig. 2B), a deposit of imbricated Colorado River gravel at least $10 \mathrm{~m}$ thick is overlain on a horizontal contact by finer grained beds (fig. 17B). Other, similar gravels underlie likely Chemehuevi Formation deposits near the elevation of the modern flood plain north of Blythe, Calif. (fig. 17B).

A basal gravel member has not been identified in bluffs bordering the flood plain in the Yuma area, and we suspect the unit may be beneath the level of the modern valley floor. On the basis of subsurface data, Olmsted and others (1973) identified a "coarse-gravel zone" beneath much of Yuma Valley and Yuma Mesa. Dickinson and others (2006) used the Olmstead data set and additional subsurface data to create a detailed three-dimensional hydrogeologic model of the Yuma area and mapped the top of what they considered to be a single groundwater reservoir known as the "coarse gravel unit." Based on its subsurface spatial distribution (Dickinson and others, 2006; their fig. 7) and its relation to the exposed stratigraphy in the area, this coarse gravel hydrogeologic unit likely includes multiple stratigraphic levels, possibly including a basal gravel layer of the Chemehuevi Formation. The gravel has a pronounced horizontal upper boundary below sands and muds that covers a wide area, at approximately $33 \mathrm{~m}$ below the modern flood plain. This upper surface drops abruptly 10 to
$20 \mathrm{~m}$ in a $5-\mathrm{km}$ wide zone trending parallel to the river valley (Dickinson and others, 2006, p. 10), which we suggest could be a paleovalley filled by the Chemehuevi Formation. If so, any basal gravel of the Chemehuevi Formation may line the base of this paleovalley as the upper part of the coarse gravel hydrogeologic unit there. This paleovalley-like feature in the subsurface gravel in part underlies Yuma Mesa (Dickinson and others, 2006), which as Lundstrom and others (2008) showed exposes and is underlain by the Chemehuevi Formation.

Throughout most of the $>700 \mathrm{~km}$ valley reach below the Grand Canyon, the top of the basal gravel member is near or just above the modern Colorado River flood plain, but near Yuma, it is $30 \mathrm{~m}$ below the flood plain surface (fig. 7). We offer two possible explanations for this: (1) that the formation has been lowered by tectonic subsidence in the Yuma Valley and (or) (2) that the basal gravel member was deposited when the Colorado River was graded to a low stand of relative sea level, such as during a glacial climate interval.

\section{Tephra Layers}

To date, five sites have been identified where a layer of tephra (volcanic ash) lies either within or immediately below the Chemehuevi Formation. Longwell (1936) identified a tephra bed in the Callville remnant (fig. 4) - the thickest continuous section of his Chemehuevis formation - which is now drowned under Lake Mead. His description referred to a "gray volcanic ash [that] forms a low cliff on which numerous inscriptions have been cut, including dates almost as early as the building of Old Callville, in $1864 \ldots$ the ash appears almost without structure through a thickness of 10 feet" (p. 1447). The ash bed is directly beneath beds typical of the mud facies of the Chemehuevi Formation, and near the top of a predominantly crossbedded coarse sand member containing scattered layers of clay and silt (appendix 4). Because it is no longer possible to visit this outcrop, we are unable to confirm Longwell's inclusion of the sand containing the tephra in the Chemehuevi Formation, or whether it may be in an older unit.

A tephra layer was discovered within the mud facies of the Chemehuevi Formation at an outcrop in Black Canyon in Arizona (Lundstrom and others, 2008). The outcrop (locality 05-94 in appendix 1) is located $1 \mathrm{~km}$ southeast of Monkey Rock in the Lake Mead National Recreation Area (Willow Beach 7.5' quadrangle). The tephra layer is approximately $15 \mathrm{~cm}$ thick, within a bedded sequence of fine sand through clay (fig. 18). The tephra consists of a layer 10 to $12 \mathrm{~cm}$ thick of primary fallout ash containing about 93 percent very fine grained glass shards, overlain by a thin brown lamina and 2 to $5 \mathrm{~cm}$ of reworked ash (fig. 18B). The ash is underlain and overlain by typical mud-facies deposits, consisting of subhorizontally bedded sequences of fine sand through clay consisting of fining upwards couplets, each containing a lower sublayer of tan silt and fine sand and an upper sublayer of reddish brown mud (appendix 8).

A reworked tephra layer as thick as $0.75 \mathrm{~m}$ including angular gravel lenses is interbedded in the mud facies of the 
Chemehuevi Formation in Cottonwood Valley, $50 \mathrm{~km}$ south of the Monkey Rock tephra site. The tephra (fig. 19a) contains about 55 percent glass shards, as well as biotite, feldspar, and aggregates of plant matter, so at least some of this bed was probably reworked by fluvial and eolian activity. The sedimentary characteristics of the sand, silt, and clay beds underlying this tephra are similar to those at the Monkey Rock site; that is, alternating layers of silty fine sand and clay-rich mud suggestive of vertically accreting flood plain deposits.

Two other tephra layers within and conformably below the mud facies of the Chemehuevi Formation are known. One of these is a layer of white ash $<0.5 \mathrm{~cm}$ thick within the mud facies at the type section (fig. 19B; appendix 1, locality 06-1107) of the Chemehuevi Formation next to the Katherine Ranger Station, in Arizona (see below for detailed description of the type locality). In addition, a reworked tephra layer 1. $5 \mathrm{~m}$ thick forms the lowest part of the Chemehuevi Formation on the eastern side of Mohave Valley, on the Fort Mojave Indian Reservation ( $\mathrm{SW} 1 / 4$, sec. 16, T17N, R21W, in the northeastern quadrant of the Needles 7.5' quadrangle) (Malmon and others, 2009). There the tephra conformably underlies the local base of the mud facies, with which it is inset on a paleosol in a small paleovalley cut into older gravelly fluvial deposits (fig. 19C). The underlying cemented gravel deposits correlate to unit B of Metzger and others (1973) and the alluvium of Bullhead City of House and others (2005b).

The four samples contain similar chemical signatures as measured by their similarity coefficients (Borchardt, 1974); when compared with the tephra at the Monkey Rock site, the coefficients of the other three samples are $0.98,0.96$, and 0.97 (table 3). These high values of geochemical similarity strongly suggest that all four tephra layers were erupted from the same volcanic center and may represent a single eruption (see section titled "Tephra Correlations and Age Constraints," for a detailed discussion of the tephra analyses). The upstream two samples (H05WB-3 and 51005-6), are the most similar among all the pairs of samples. These samples are also the best matches to one another from the database of tephra samples from the western conterminous United States, maintained by the USGS Tephrochronology Project, that contains more than 6,000 samples. The match between the two is close enough to conclude they are probably from the same eruption. Thus, this tephra bed constitutes a marker horizon within the Chemehuevi Formation, which we informally refer to as the Monkey Rock tephra bed.

The interpretation of the chemistry of the other two samples (from Katherine Landing and Fort Mohave) is more equivocal. They are similar enough to the Monkey Rock tephra bed to indicate that they are probably from the same volcanic source area. However, they are different enough that they may represent different eruptions, which could have been separated by days or by thousands of years. The fact that the elevations of the four tephra samples form a nearly straight line in the longitudinal profile (fig. 17) suggests that the eruptions were fairly closely spaced in time, and thus they record the general river valley gradient at the time of their eruption.

\section{Boundaries}

To assign the formation as a lithostratigraphic unit, its boundaries must be clearly defined. The Stratigraphic Code specifies that "boundaries of lithostratigraphic units are placed at positions of lithic change" (North American Commission on Stratigraphic Nomenclature, 2005, p. 1567). Thus, regionally extensive unconformities, where they exist, are ideal boundaries for lithostratigraphic units. Other possible criteria for determining the vertical and lateral boundaries include regionally extensive key beds or marker horizons, or distinct lateral or vertical changes in lithology. In addition, the Code advises that boundaries of lithostratigraphic units should be placed "where feasible, to correspond with the boundaries of genetic units, so that subsequent studies of genesis will not have to deal with units that straddle formal boundaries" (North American Commission on Stratigraphic Nomenclature, 2005, p. 1567). Because the formation consists of widely scattered remnants deposited over and overlain by a wide variety of substrates, a clear, objective delineation of its boundaries is difficult or impossible. In defining the boundaries, we attempt to use criteria specified in the Stratigraphic Code to the extent possible. However, we also give consideration to factors that will be most consistent with past usage and make it easier to map the formation and interpret its origin.

\section{Base of the Formation}

The Chemehuevi Formation is distributed throughout a branching valley network hundreds of $\mathrm{km}$ in total length and several to tens of $\mathrm{km}$ wide along the valley of the lower Colorado River and its tributaries throughout the Basin and Range Province. Thus, the formation overlies varied Proterozoic through Miocene rocks, and also Pliocene and Pleistocene deposits related to the inception and earlier evolution of the Colorado River valley. In most places, the base of the Chemehuevi Formation is an unconformity, with beds of the formation overlying older materials with tens of meters of relief. In these places, the Chemehuevi Formation overlies (1) Miocene and older bedrock formations, (2) the latest Miocene to early Pliocene Bouse Formation (Metzger, 1968), (3) Pliocene sand and gravel river deposits that Metzger and others (1973) referred to as "unit B of the older alluviums" (Metzger and others, 1973) and that House and others (2005b) called the "alluvium of Bullhead City", (4) locally derived fan gravels (unit C of Metzger and Loeltz, 1973; Metzger and others, 1973), and (5) older Quaternary Colorado River deposits (House and others, 2005b; Malmon and others, 2009) that postdate unit B but are older than the Chemehuevi Formation. At the type locality, the formation overlies megacrystic Proterozoic granite. Where the formation overlies erosional topography on older fan gravel and river gravels, the contact is commonly marked by paleosols, typically exhibiting stage IIIII carbonate morphology. These paleosols record an apparent prolonged period of landscape exposure before the deposition of the Chemehuevi Formation. 


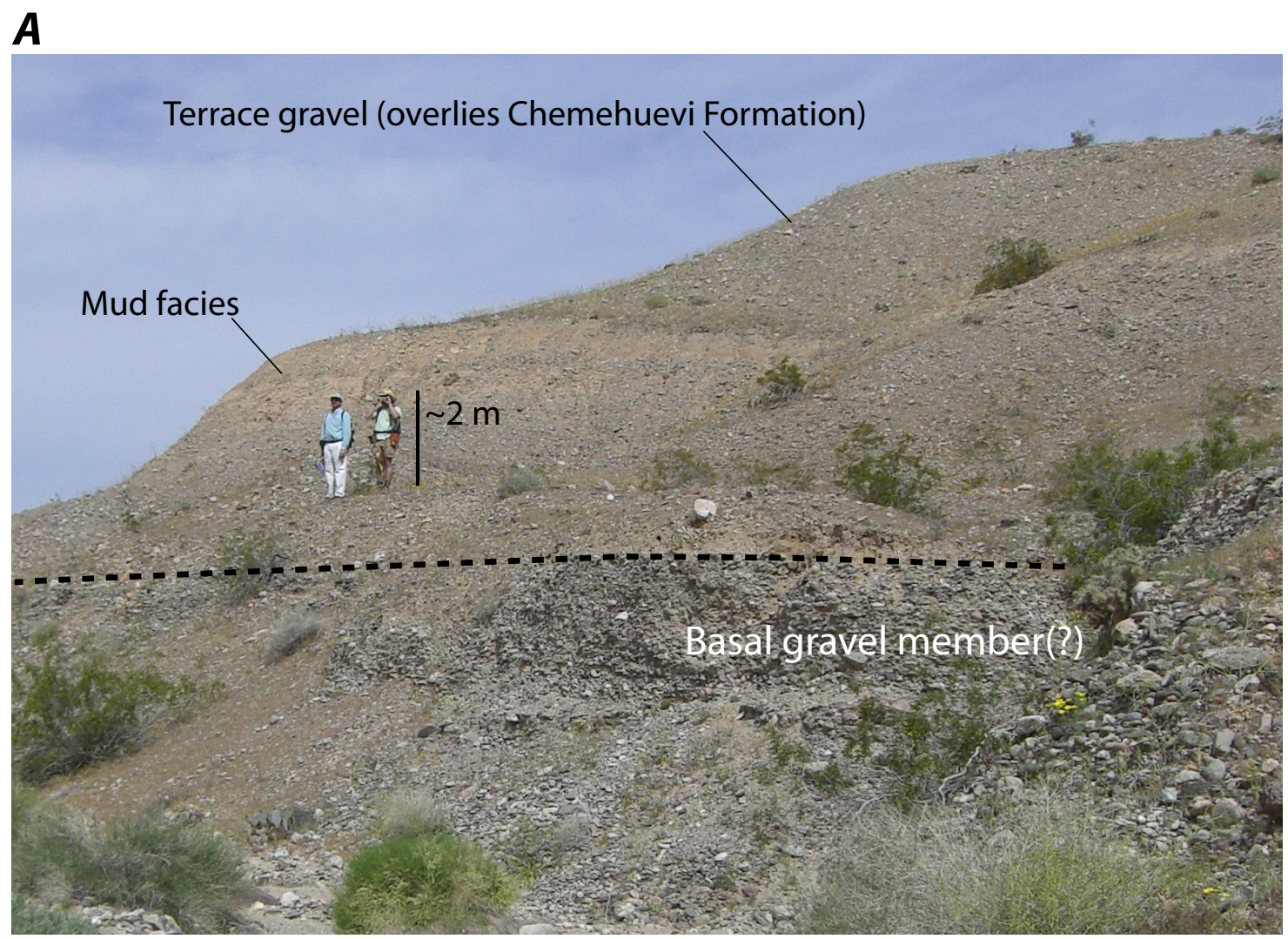

B

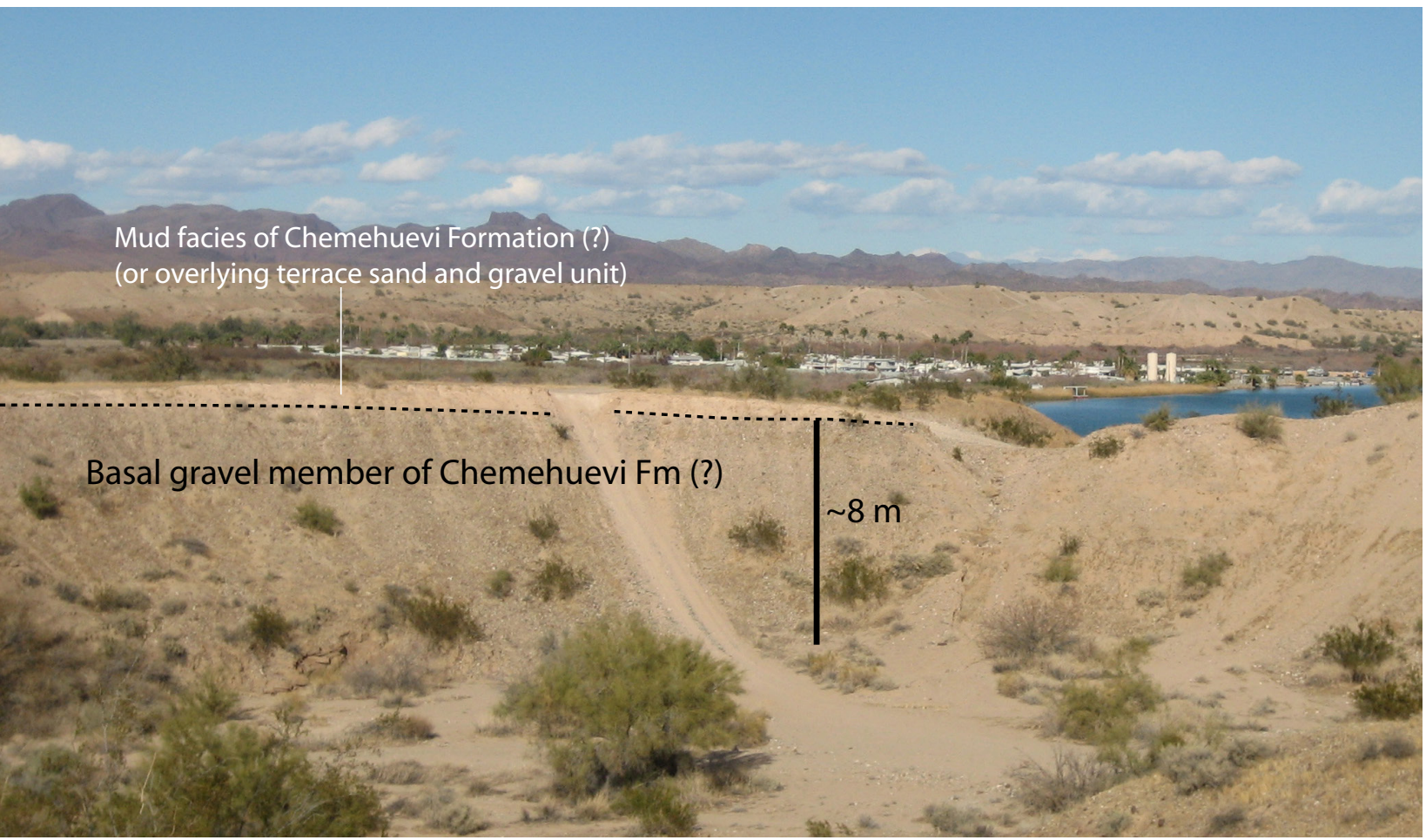

Figure 17. Possible examples of the basal gravel member of the Chemehuevi Formation. Examples are noncemented fluvial gravel with near-horizontal upper boundary that conformably underlie the Chemehuevi Formation. $A$, Near Laughlin, Nev. (SE 1/4 sec. 26, T. 32 S., R. 22 W., Davis Dam 7.5' quadrangle; Table 2, locality 08-320-2). B, Near Parker, Ariz. (NE 1/4 sec. 32, T. 10 N., R. 19 W., Parker 7.5' quadrangle; table 2, locality 06-230). C, Closeup of river gravel underlying finer grained facies of the Chemehuevi Formation, north of Blythe, Calif. 
We consider the stratigraphic base of the formation to be the unconformable bottom of the lowest part of the conformable sequence that includes the mud and sand facies of the formation. The base of the proposed basal gravel member conforms to these relations, as described by Longwell (1936) in his now-submerged Sandy Point exposure, and by Metzger and others (1973) from a drill log (appendix 7). The base of the basal gravel generally lies below the elevation of the modern flood plain and is difficult to distinguish from older Colorado River gravels of similar lithology, as seen in appendix 7. However, because there is considerable evidence that the mud and sand facies are conformably underlain by a basal gravel sequence, this lower member should be included in the formation. Thus, for now, we propose that the lower stratigraphic boundary of the formation is an erosional unconformity at the bottom of the basal gravel member (fig. 5D).

\section{Top of the Formation and Overlying Terrace Gravel Sequence}

The top of the Chemehuevi Formation is in most places an erosional surface. Along the Colorado River valley margins, the unconformable top of the formation is commonly overlain by angular, locally derived gravel as much as several meters thick and having an upper surface that slopes toward the valley axis (for example, fig. 20A). In many of the typical remnants of the formation, including the type section, the highest exposure of the formation is the sand facies. In many places where the upper surface of the Chemehuevi Formation is exposed or covered by younger units, carbonate soils with stage-II morphology have developed at the surface (fig. 11F).

C

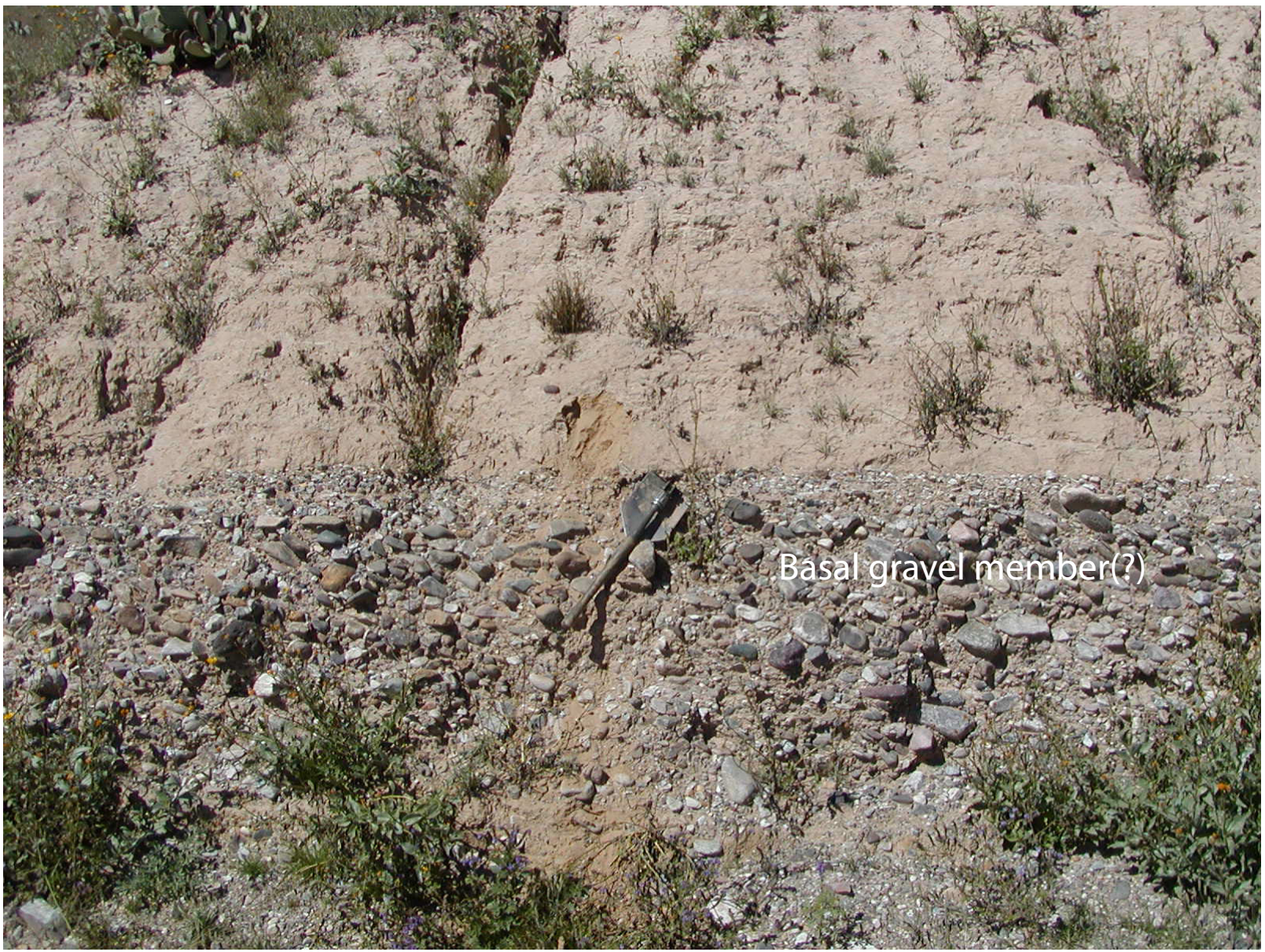

Figure 17. Continued 

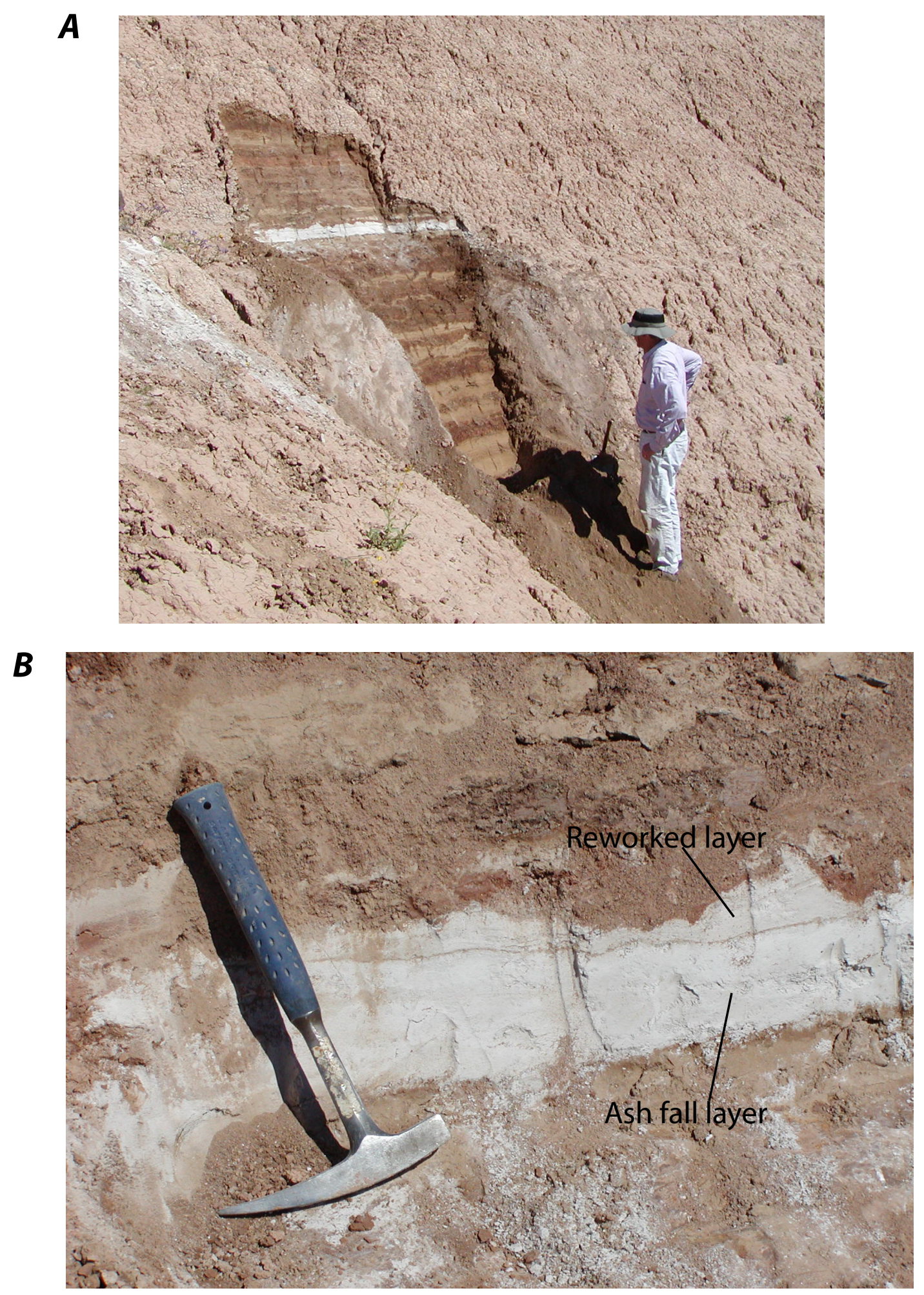

Figure 18. Monkey Rock tephra bed near Monkey Rock, Ariz. (appendix 1, locality 05-94). A, Cleared photograph of outcrop showing bedding in the mud facies above and below the light-colored tephra bed. Detailed measured section is in appendix 8. B, Closeup of tephra bed showing a lower ash fall layer, and an upper reworked layer. 
$\boldsymbol{A}$

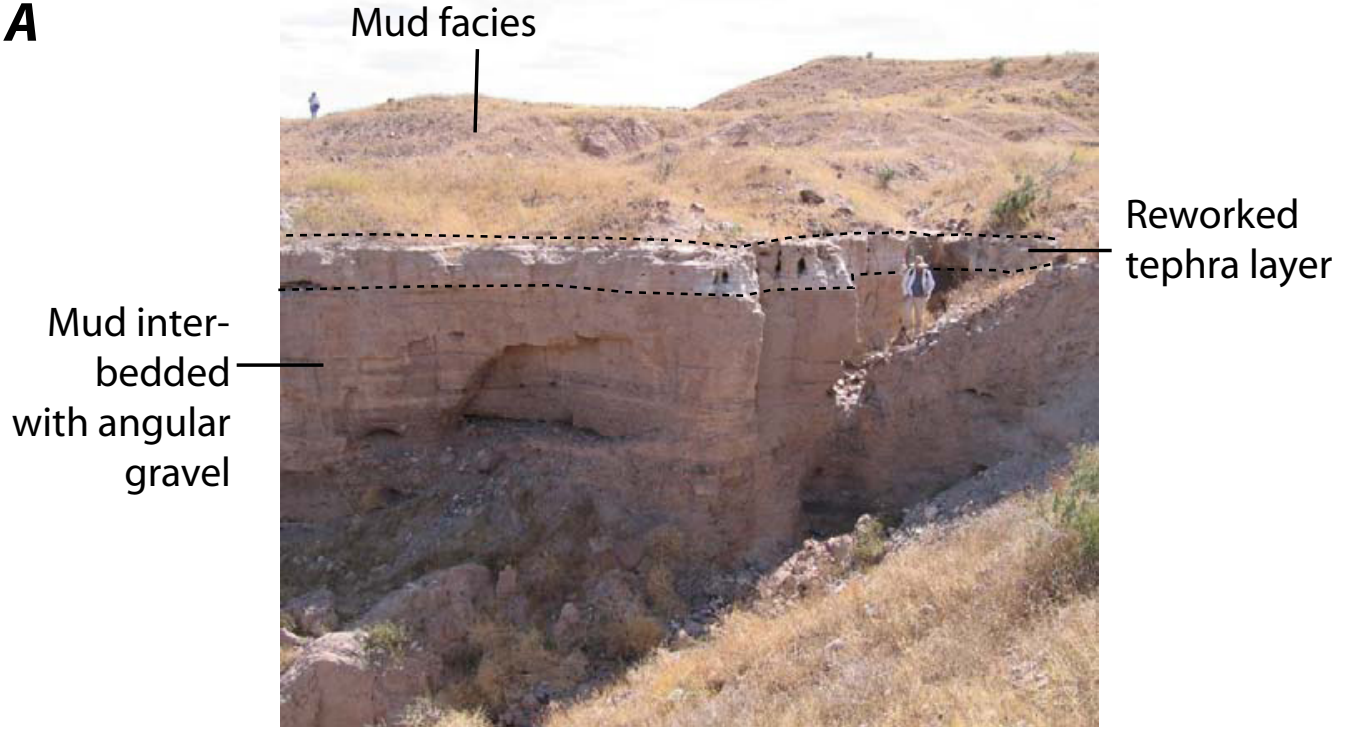

B

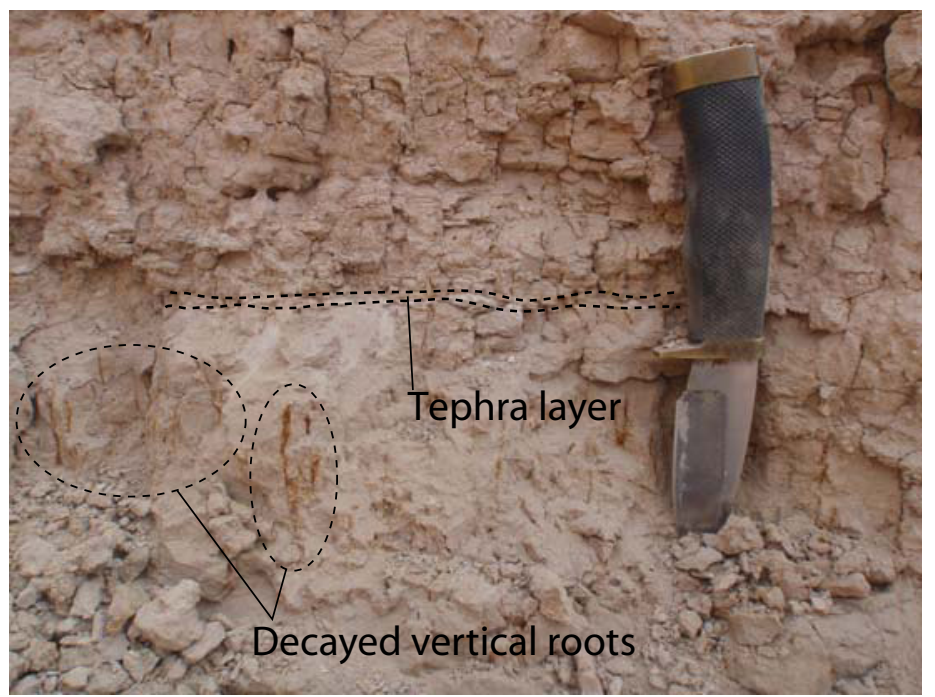

C

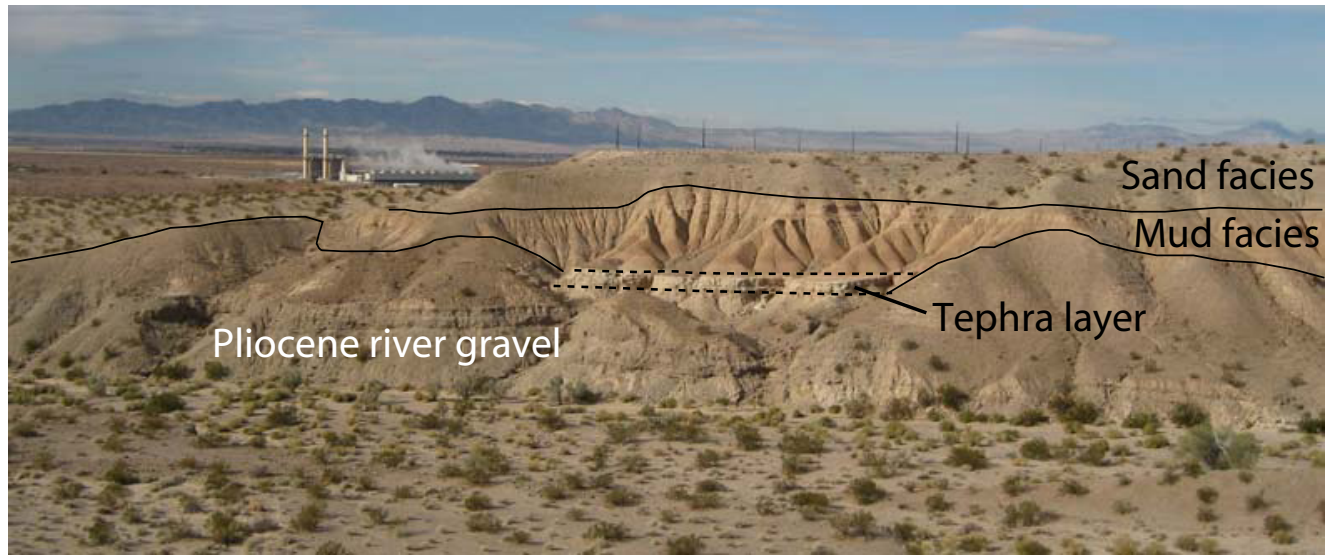

Figure 19. Photographs of tephra layers in and below the Chemehuevi Formation at three localities. $A$, Reworked tephra layer $0.75 \mathrm{~m}$ thick in a generally fining upwards section of the mud facies, Desert Cove, Ariz. (appendix 1, locality 06-1107-5); $B$, Tephra layer in the type section of the Chemehuevi Formation at Katherine Landing, Ariz. (appendix 1, locality $07-425-5$ ). Knife handle is $10 \mathrm{~cm}$ long. $C$, Layer of reworked tephra underlying Chemehuevi Formation mud in a paleovalley on the Fort Mojave Indian Reservation, Ariz. (appendix 1, locality 06-1222-2). Outcrop is approximately $25 \mathrm{~m}$ high. 
Table 3. Summary of stratigraphic context and oxide geochemistry data of samples of glass in tephra from the Chemehuevi Formation.

\begin{tabular}{|c|c|c|c|c|c|c|c|c|c|c|c|c|c|c|}
\hline $\begin{array}{l}\text { USGS } \\
\text { Tephrochronology } \\
\text { Laboratory Sample }^{\text {Number }}{ }^{1}\end{array}$ & Location Description & Stratigraphic Context & Locality ID ${ }^{2}$ & $\begin{array}{l}\text { Number of } \\
\text { Glass } \\
\text { Shards } \\
\text { Analyzed }\end{array}$ & $\mathrm{SiO}_{2}$ & $\mathrm{Al}_{2} \mathrm{O}_{3}$ & $\mathrm{Fe}_{2} \mathrm{O}_{3}$ & MgO & $\mathrm{MnO}$ & $\mathrm{CaO}$ & $\mathrm{TiO}_{2}$ & $\mathrm{Na}_{2} \mathrm{O}$ & $\mathrm{K}_{2} \mathrm{O}$ & $\begin{array}{c}\text { Similarity } \\
\text { Coefficient }\end{array}$ \\
\hline H05WB-3 & $\begin{array}{l}\text { In Black Canyon, Ariz., near } \\
\text { Monkey Rock (Lundstrom and } \\
\text { others, 2008) }\end{array}$ & $\begin{array}{l}\text { Interbedded in mud facies; } 10 \\
\mathrm{~cm} \text { fallout layer overlain by } \\
\text { reworked layer } 5 \mathrm{~cm} \text { thick (fig. } \\
\text { 18) }\end{array}$ & $05-94$ & 16 & 74.05 & 15.29 & 1.44 & 0.15 & 0.11 & 0.56 & 0.18 & 4.04 & 4.17 & 1 \\
\hline $51005-6$ & $\begin{array}{l}\text { East shore of Lake Mohave, } \\
\text { Desert Cove, Ariz. }\end{array}$ & $\begin{array}{l}\text { Interbedded in mud facies; } \\
\text { possibly fallout ash; } 0.25 \text { - } \\
0.75 \mathrm{~m} \text { thick (fig. 19A) }\end{array}$ & $06-1107-5$ & 19 & 73.94 & 15.34 & 1.45 & 0.14 & 0.11 & 0.56 & 0.17 & 4.07 & 4.22 & 0.9777 \\
\hline DM-06-1107-12 & $\begin{array}{l}\text { Katherine Ranger Station } \\
\text { Ariz., in type section of } \\
\text { Chemehuevi Fm }\end{array}$ & $\begin{array}{l}\text { Interbedded in mud facies; } \\
\text { reworked?; layer less than } 5 \\
\text { mm thick (fig. 19B) }\end{array}$ & $06-1107-12$ & 18 & 73.66 & 15.24 & 1.41 & 0.16 & 0.10 & 0.60 & 0.19 & 3.81 & 4.84 & 0.9648 \\
\hline DM-06-1222-2 (pop 2) & $\begin{array}{l}\text { Ft. Mojave Indian Reservation, } \\
\text { Ariz., south of powerplant } \\
\text { (Malmon and others, 2009a) }\end{array}$ & $\begin{array}{l}\text { Underlies mud facies; } \\
\text { reworked and mixed with } \\
\text { sand and mud; } 1 \text { to } 2 \mathrm{~m} \text { thick } \\
\text { (fig. } 19 \mathrm{C} \text { ) }\end{array}$ & $06-1222-2$ & 16 & 72.69 & 15.16 & 1.27 & 0.15 & 0.08 & 0.54 & 0.18 & 5.03 & 4.91 & 0.9699 \\
\hline
\end{tabular}

${ }^{1}$ Geochemistry from microprobe analysis of glass shards at the USGS Tephrochronology Laboratory in Menlo Park, Calif., 2005-2007.

${ }^{2}$ Locality ID refers to the GPS site listed in appendix 1.

${ }^{3}$ Sample consists of two separate populations. Data presented are from 16 shards from main population; a secondary population of chemically distinct glass shards

is likely reworked from Miocene or Pliocene tephra. 
In a number of places, the Chemehuevi Formation is unconformably overlain by Colorado River sediments associated with fluvial terraces and scarps cut into the formation (fig. 20B). Some of the terraces are straths cut on Chemehuevi Formation deposits and marked by thin veneers of scattered river pebbles, and others are the tops of inset accumulations of river gravel as thick as tens of meters (for example, Longwell, 1936; Lundstrom and others, 2008). Blackwelder (1934) reported 9 to 12 terraces at elevations from 10 to $225 \mathrm{ft}$ ( 3 to $69 \mathrm{~m}$ ) above the flood plain in the area now under Lake Mead. Longwell (1936) described and measured post-Chemehuevi flights of gravel terraces paired on both sides of the Colorado River. Among the most prominent of the terrace levels was one at 170 to $180 \mathrm{ft}$ (56 to $59 \mathrm{~m}$ ) above the river. Another prominent terrace at 60 to $75 \mathrm{ft}$ ( 20 to $25 \mathrm{~m}$ ) above the river was mined for gravel for Hoover Dam. Longwell (1936) referred to gravel deposits immediately underlying the terraces as the terrace gravels and interpreted them as having deposited Aduring interruptions in downcutting that followed deposition of his Chemehuevis formation (fig. 6A).

We also infer that the erosional unconformity between the Chemehuevi Formation and the overlying unit of terrace gravel and sand is a laterally traceable discontinuity, and consider it to be the stratigraphic top of the formation (figs. $5 D$ and $6 D$ ). As defined here, the Chemehuevi Formation represents an aggradational sequence, and, in keeping with Longwell's (1936) concept, Colorado River fluvial gravels cut into the formation are not considered to be part of the formation.

At the culmination of the aggradation, the river planed laterally for a long enough period that it cut scarps into older alluvial-fan gravel deposits. Valley-facing fluvial scarps near the highest elevation of the Chemehuevi Formation have been mapped in Parker Valley (Dickey and others, 1980; Stone, 2006) and in Mohave Valley (Pearthree and House, 2005; Malmon and others, 2009). Sediments deposited at or near the culmination of the Chemehuevi aggradation, before onset of major river downcutting, are considered here to be part of the Chemehuevi Formation, as they do not overlie the unconformity marking the upper bounding surface of the formation (fig. 6D).

\section{No Regional Internal Unconformities}

Our conception of the formation is that it contains no significant regional unconformities marking inset relations among units of significantly different age. The Stratigraphic Code (North American Commission on Stratigraphic Nomenclature, 2005) discourages the inclusion of regional disconformities within lithostratigraphic units. The formation, as we perceive it, represents a single stratigraphic package, which is interpreted as the latest large $(>100 \mathrm{~m})$ aggradation of the Colorado River. The formation also likely includes a regionally extensive basal gravel unit, which is conformable beneath the aggradational package. Some Colorado River deposits with similar lithology predate the Chemehuevi Formation and have been tentatively mapped as separate from the Chemehuevi
Formation on the basis of stratigraphic relations with local piedmont fan gravels (for example, the Riverside beds of House and others (2005b) and the Needles beds of Malmon and others (2009a)). These sediments do not belong to the Chemehuevi Formation as described here. Younger inset units, including the terrace gravel unit, are separate stratigraphic units, as they overlie the regional unconformity that marks the top of the formation. Because the formation only exists as scattered, discontinuous outcrops, it is possible that some of the remnants assumed here to be part of the Chemehuevi Formation are actually part of a younger aggradational sequence. Although we have not seen evidence for major aggradation events younger than the Chemehuevi Formation that were much higher than the modern flood plain, we do not rule out the possibility that younger, smaller fill sequences exist. If so, the sediments that were deposited during that aggradation are not part of the formation as defined here, because they are not correlative to the sediments at the type section.

\section{Previous Age Control}

Numerical ages have been reported for the Chemehuevi Formation using a variety of geochronologic methods (table 4). For some of the dates reported in table 4, the stratigraphic context of the sampled units is ambiguous, and in other cases the results of geochronologic analyses were inconclusive or unreliable. Here we summarize what is known about the age of the formation from previous geochronology.

Maximum ages for the formation are provided by fossil evidence. Newberry found a "very large and perfect tooth of Elephas primigenius in the bed of cemented coarse [boulder] gravel" that underlies almost $35 \mathrm{~m}$ of mud and sand beds near the mouth of Black Canyon (fig. 3). This genus is known as Mammuthus in modern taxonomy and was present in North America during the middle to late Pleistocene (Metzger and others, 1973). Whether or not the now-submerged host gravel is part of the Chemehuevi Formation, or part of an older gravel-rich stratigraphic unit, Newberry's discovery of a Pleistocene tooth established that the formation is Pleistocene or younger, the first age control for the overlying fine-grained deposits.

Other fossils (Longwell, 1936; Metzger and others, 1973; Agenbroad and others, 1992) found within and stratigraphically below the Chemehuevi Formation demonstrate that the formation is of middle or late Pleistocene age. Longwell (1936, p. 1453) stated that the only significant fossil discovery he had made in the formation was the core of a bison's horn in the upper rhythmite facies at Old Callville, but, citing a paleontologist, declared that it was not age diagnostic. The bison horn indicates a Rancholabrean Land Mammal age (middle to late Pleistocene), according to Agenbroad and others (1992). Longwell (1946) reported vertebrate and invertebrate fossil remains in light-colored clays and silts in Las Vegas Valley, which he believed correlated to the Chemehuevi Formation along the main stem. These included fragments 


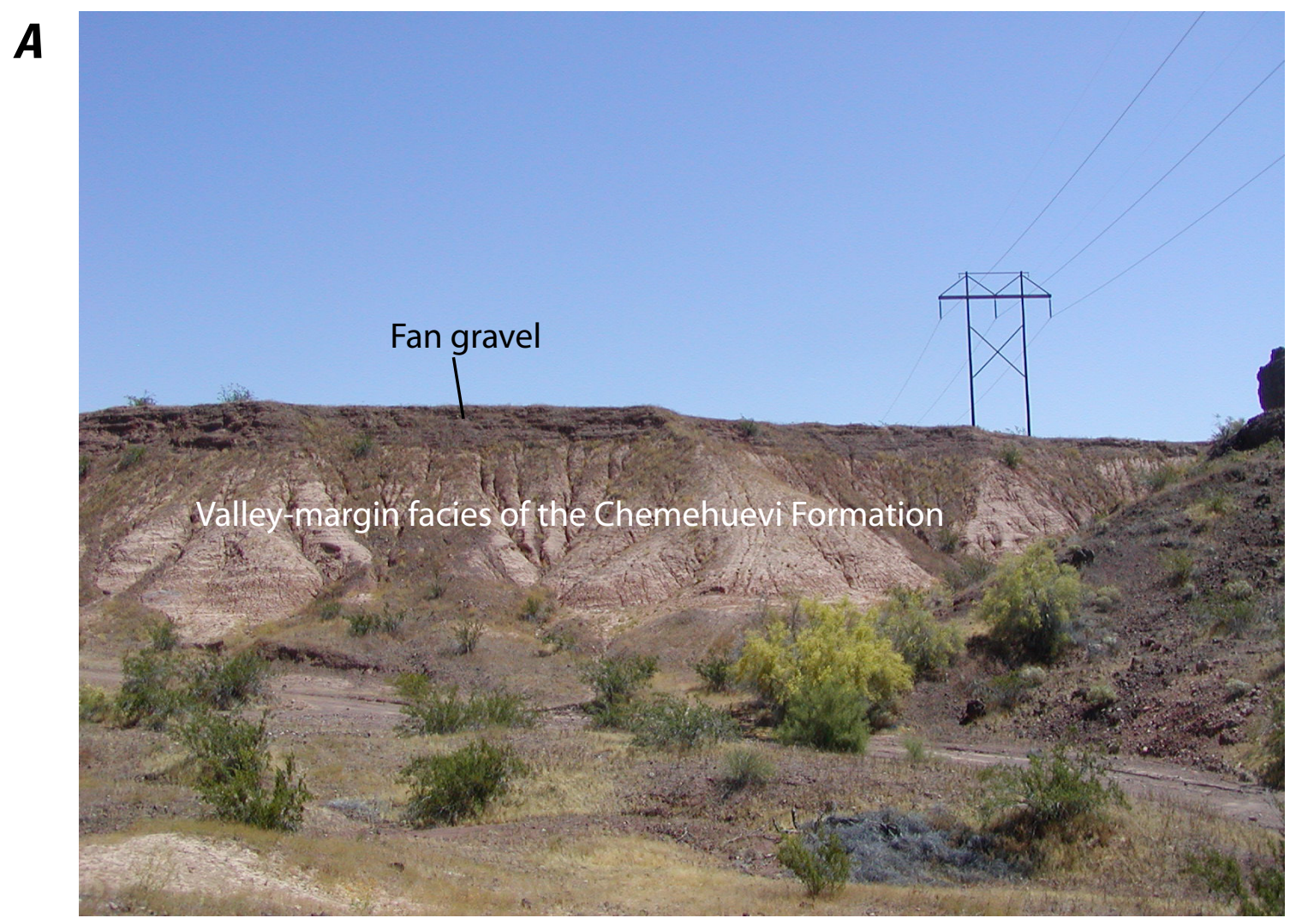

B

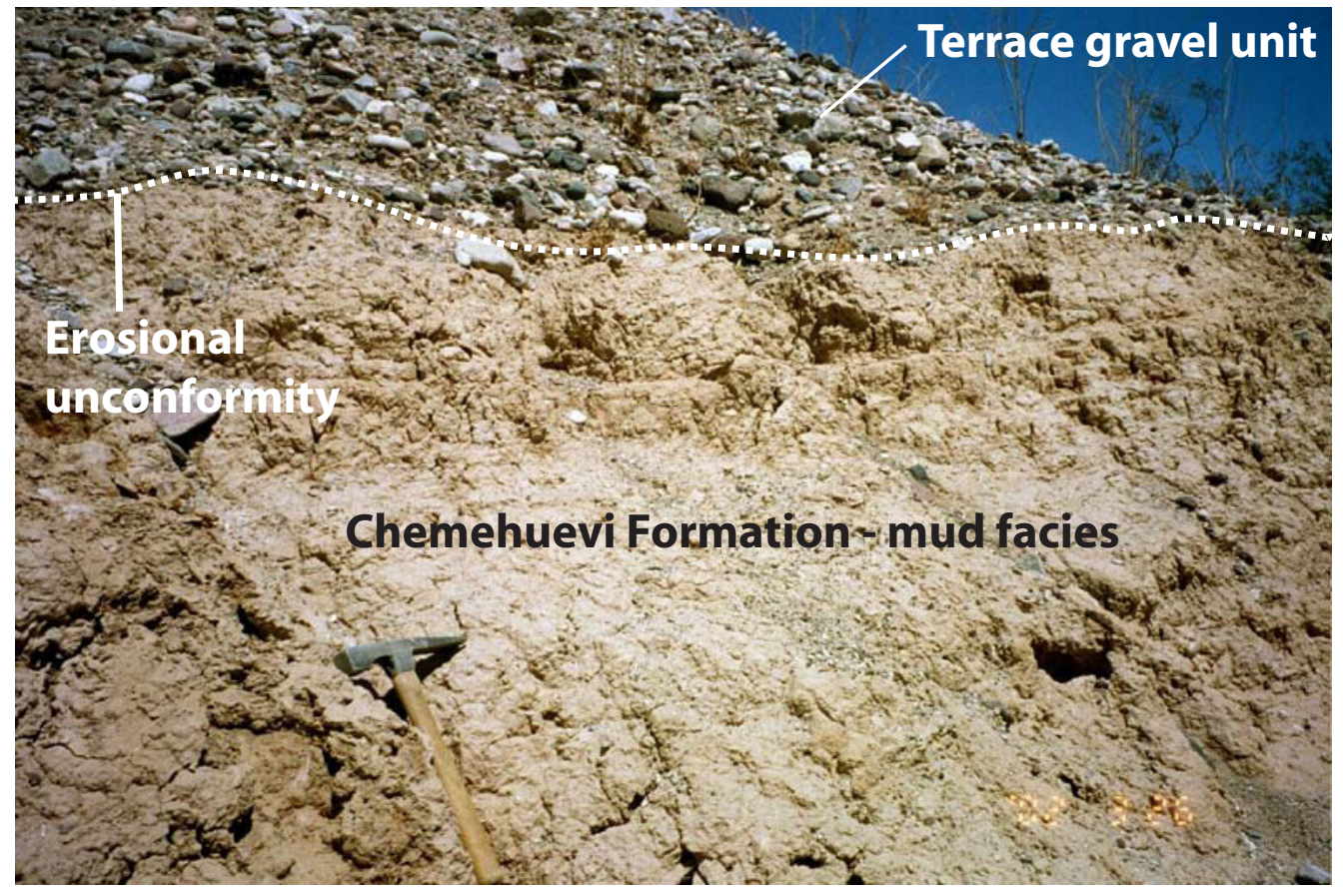

Figure 20. Photographs showing the upper stratigraphic boundary of the Chemehuevi Formation. $A$, Locally derived fan gravel overlying the Chemehuevi Formation on an erosional surface south of Parker Dam, Calif. (appendix 1, locality 05-147). Exposure is approximately $15 \mathrm{~m}$ high. $B$, Terrace sand and gravel unit overlying the Chemehuevi Formation, on east side of Lake Mohave near Cottonwood Cove, Nev. Hammer is $0.3 \mathrm{~m}$ long. 
Table 4. Previous numerical age control for deposits related to the Chemeheuvi Formation.

[sm., small; vert., vertical; frag., fragment. Geochronologic methods; IRSL, infrared simulated luminescence; OSL, optically simulated luminescence; TIMS, thermal ionization mass spectrometry]

\begin{tabular}{|c|c|c|c|c|c|c|}
\hline $\begin{array}{l}\text { Sample } \\
\text { Number }\end{array}$ & $\begin{array}{l}\text { Geochronologic } \\
\text { Method }\end{array}$ & Material & Stratigraphic Contex & Location & $\begin{array}{l}\text { Age or Age } \\
\text { Range }\end{array}$ & References \\
\hline $\begin{array}{l}\text { multiple } \\
\text { samples }\end{array}$ & Paleontology & vertebrate fossils & below or within mud facies ${ }^{1}$ & multiple localities & $<1.7 \mathrm{Ma}$ & $\begin{array}{l}\text { Newberry, in Ives, 1852; Metzger and others, } \\
\text { 1973; Agenbroad and others, } 1992\end{array}$ \\
\hline $\begin{array}{l}\text { multiple } \\
\text { samples }\end{array}$ & Magnetostratigraphy & silt/clay & within mud facies ${ }^{2}$ & multiple localities & $<780 \mathrm{ka}^{3}$ & $\begin{array}{l}\text { Kukla, 1975; Bell and others, 1978; Lundstrom } \\
\text { and others, } 2008\end{array}$ \\
\hline$A D-1$ & Amino acid & mammoth skull & within mud facies ${ }^{2}$ & near Ehrenberg, $A Z$ & $>250 \mathrm{ka}^{4}$ & Fugro, Inc., 1975 \\
\hline AD-2 & Amino acid & mammoth tusk & within mud facies ${ }^{2}$ & near Ehrenberg, AZ & $>40 \mathrm{ka}^{4}$ & Fugro, Inc., 1975 \\
\hline$A D-3$ & Amino acid & horse tooth & within mud facies ${ }^{2}$ & near Ehrenberg, AZ & $>50 \mathrm{ka}^{4}$ & Fugro, Inc., 1975 \\
\hline$A D-4$ & Amino acid & sm. vert. frag. & within mud facies ${ }^{2}$ & near Ehrenberg, AZ & $>10 \mathrm{ka}^{4}$ & Fugro, Inc., 1975 \\
\hline AD-5 & Amino acid & sm. vert. frag. & within mud facies ${ }^{2}$ & near Ehrenberg, AZ & $>40 \mathrm{ka}^{4}$ & Fugro, Inc., 1975 \\
\hline AD-6 & Amino acid & sm. vert. frag. & within mud facies ${ }^{2}$ & near Ehrenberg, AZ & $>84 \mathrm{ka}^{4}$ & Fugro, Inc., 1975 \\
\hline AD-7 & Amino acid & sm. vert. frag. & within mud facies ${ }^{2}$ & near Ehrenberg, $A Z$ & $>32 \mathrm{ka}^{4}$ & Fugro, Inc., 1975 \\
\hline AD-8 & Amino acid & sm. vert. frag. & within mud facies ${ }^{2}$ & near Ehrenberg, $A Z$ & $>40 \mathrm{ka}^{4}$ & Fugro, Inc., 1975 \\
\hline \multirow[t]{4}{*}{ C-2 } & Radiocarbon & mammoth tusk & within or below mud facies ${ }^{2}$ & near Ehrenberg, $A Z$ & $>40 \mathrm{ka}^{5}$ & Fugro, Inc., 1975 \\
\hline & U-Series & mammoth tusk & within mud facies & W. of Parker, AZ & $102 \pm 7 \mathrm{ka}$ & Bell and others, 1978 \\
\hline & U-Series & pedogenic caliches & overlying mud facies & near Parker, AZ & $>30-90 \mathrm{ka}^{6}$ & Bell and others, 1978 \\
\hline & Radiocarbon & wood fragment & within mud facies ${ }^{2}$ & N. of Nelson, NV & $40.4 \pm 0.4 \mathrm{ka}^{7}$ & Blair, 1996 \\
\hline LV-7 & IRSL & silt/sand & within mud facies ${ }^{2}$ & E. of Cottonwood, NV & $49-70 \mathrm{ka}^{8}$ & Lundstrom and others, 2008 \\
\hline LV-8 & IRSL & silt/sand & within mud facies ${ }^{2}$ & Cottonwood Cove, NV & $41-59 \mathrm{ka}^{8}$ & Lundstrom and others, 2008 \\
\hline LV-9 & IRSL & silt/sand & within mud facies ${ }^{2}$ & Cottonwood Cove, NV & $41-59 \mathrm{ka}^{8}$ & Lundstrom and others, 2008 \\
\hline LV-10 & IRSL & silt/sand & within mud facies ${ }^{2}$ & Cottonwood Cove, NV & $45-68 k a^{8}$ & Lundstrom and others, 2008 \\
\hline LV-11 & IRSL & silt/sand & within tributary facies ${ }^{2}$ & Las Vegas Wash, NV & $56-81 \mathrm{ka}^{8}$ & Lundstrom and others, 2008 \\
\hline LV-12 & IRSL & silt/sand & within tributary facies ${ }^{2}$ & Las Vegas Wash, NV & $50-73 k a^{8}$ & Lundstrom and others, 2008 \\
\hline COR-1 Yuma & OSL & silt/sand & within mud facies ${ }^{2}$ & Yuma, AZ & $45-58 \mathrm{ka}^{6}$ & Lundstrom and others, 2008 \\
\hline COR-2 Yuma & OSL & silt/sand & sand facies ${ }^{2}$ & Yuma, AZ & $31-41 k a^{8}$ & Lundstrom and others, 2008 \\
\hline $\begin{array}{l}\text { multiple } \\
\text { samples }^{7}\end{array}$ & U-Series (TIMS) & $\begin{array}{l}\text { carbonate clast } \\
\text { coatings }\end{array}$ & terrace gravels $(?)^{2}$ & E. of Cottonwood, NV & $43-68 k a^{9}$ & Lundstrom and others, 2008 \\
\hline
\end{tabular}

${ }^{1}$ Vertebrate fossils are from the mud facies or from beneath the mud facies.

${ }^{2}$ Stratigraphic context with respect to the Chemehuevi Formation determined on the basis of field inspection by one or more of the authors.

${ }^{3} \mathrm{Age}$ less than $780 \mathrm{ka}$ based on the observation that all samples were normally magnetized.

${ }^{4} \mathrm{All}$ ages for amino acid technique reported as minimum ages (Fugro, Inc., 1975).

${ }^{5}$ Sample contained no detectable radiocarbon; $>40$ ka age specification based on approximate maximum age of radiocarbon dating method.

${ }^{6}$ Reported as minimum Th230/U235 age range for pedogenic caliches said to overlie formation.

${ }^{7} \mathrm{Age}$ in calendar years as calibrated from the Fairbanks0107 curve (Fairbanks and others, 2005); original reported age of $35.1 \pm 0.4 \mathrm{ka}$

${ }^{8}$ Minimum luminescence age assumes dry history for samples and maximum age reflects assumption of saturated moisture history.

${ }^{9}$ Range of mean age for nine of 11 samples in overlying terrace gravel; two other samples dated as $32.4 \pm 0.9 \mathrm{ka}$ and $94.4 \pm 7.2$ ka interpreted by authors as suspect. 
Table 5. Similarity coefficients (SIMAN function of Borchardt, 1974) for glass of tephra samples 1, using six oxides, less the alkalies $\mathrm{Na}_{2} \mathrm{O}, \mathrm{K}_{2} \mathrm{O}$, and $\mathrm{MnO}$.

[Analyses by C.E. Meyer, J. Walker, D. Wahl, and E. Wan, U.S. Geological Survey Tephrochronology Laboratory, Menlo Park, Calif., 1980-2009]

\begin{tabular}{|c|c|c|c|c|c|c|c|c|c|c|c|c|c|c|c|c|c|}
\hline Sample & $\begin{array}{l}\text { HO5WB-3 } \\
\text { (Monkey } \\
\text { Rock) }\end{array}$ & \begin{tabular}{|c|}
$51005-6$ \\
(Lake \\
Mohave)
\end{tabular} & \begin{tabular}{|c|} 
DM-06- \\
$1107-12$ \\
(Loaf \\
Rock)
\end{tabular} & $\mid \begin{array}{c}\text { DM-06-1222 } \\
2 \text { (pop 2) } \\
\text { (Ft. Mohave } \\
\text { Reservation } \\
\text { ) }\end{array}$ & $\begin{array}{c}\mathrm{CKS}(\mathrm{ws}) \\
1\end{array}$ & $\begin{array}{c}\text { SGW- } \\
\text { SV1-2008 }\end{array}$ & $\begin{array}{l}\text { AL98- } \\
51 \mathrm{~A}\end{array}$ & $\begin{array}{c}\text { OL92-1 } \\
(41.5 \mathrm{~m}) \\
\text { A }\end{array}$ & $\begin{array}{c}\text { OL92-1 } \\
(41.5 \mathrm{~m}) \\
\mathrm{B}\end{array}$ & $\begin{array}{c}\text { KRL- } \\
\text { 71082(II- } \\
\text { 5) A }\end{array}$ & $\begin{array}{c}\text { WL4- } \\
26(66.4 \mathrm{~m} \\
)\end{array}$ & \begin{tabular}{|c} 
KRL- \\
71082(II- \\
3) B
\end{tabular} & $\begin{array}{c}\text { 1-JWB- } \\
\mathrm{CM}-3\end{array}$ & $\begin{array}{l}\text { 1-JWB- } \\
\text { CM-2 }\end{array}$ & $\begin{array}{c}\text { M-329 } \\
\text { (Mammoth } \\
\text { Mt.) }\end{array}$ & $\begin{array}{c}\text { M-179 } \\
\text { (Mammoth } \\
\text { Mt.) }\end{array}$ & $\begin{array}{c}\text { OL92-1 } \\
(47.9 \mathrm{~m}) \\
\text { (pop 2) C }\end{array}$ \\
\hline $\begin{array}{c}\text { H05WB-3 (Monkey } \\
\text { Rock) }\end{array}$ & 1.000 & & & & & & & & & & & & & & & & \\
\hline $\begin{array}{c}\text { 51005-6 (Lake } \\
\text { Mohave) }\end{array}$ & 0.978 & 1.000 & & & & & & & & & & & & & & & \\
\hline $\begin{array}{c}\text { DM-06-1222-2 } \\
\text { (pop2) (Ft. Mohave } \\
\text { Reservation) }\end{array}$ & 0.970 & $\mid 0.948$ & 0.945 & 1.000 & & & & & & & & & & & & & \\
\hline CKS(WS)-1 & 0.983 & 0.962 & 0.974 & 0.980 & 1.000 & & & & & & & & & & & & \\
\hline SGW-SV1-2008 & 0.943 & 0.948 & 0.938 & 0.919 & 0.938 & 1.000 & & & & & & & & & & & \\
\hline OL92-1 $(41.5 \mathrm{~m})$ B & $<0.900$ & $<0.900$ & 0.918 & $<0.900$ & 0.912 & 0.914 & $<0.900$ & 0.941 & 1.000 & & & & & & & & \\
\hline KRL-71082 (II-5) A & 0.906 & $<0.900$ & 0.912 & 0.910 & 0.912 & 0.914 & $<0.900$ & 0.932 & 0.926 & 1.000 & & & & & & & \\
\hline WL4-26 (66.4m) & 0.906 & $<0.900$ & 0.933 & 0.912 & 0.924 & 0.915 & 0.901 & 0.934 & 0.953 & 0.970 & 1.000 & & & & & & \\
\hline KRL-71082 (II-3) B & $<0.900$ & $<0.900$ & $<0.900$ & 0.906 & $<0.900$ & $<0.900$ & $<0.900$ & $<0.900$ & $<0.900$ & 0.900 & 0.908 & 1.000 & & & & & \\
\hline 1-JWB-CM-3 & 0.902 & 0.902 & $<0.900$ & 0.926 & 0.911 & 0.905 & 0.926 & $<0.900$ & $<0.900$ & $<0.900$ & $<0.900$ & 0.965 & 1.000 & & & & \\
\hline 1-JWB-CM-2 & 0.910 & 0.910 & 0.904 & 0.934 & 0.919 & 0.913 & 0.932 & $<0.900$ & $<0.900$ & $<0.900$ & $<0.900$ & 0.963 & 0.991 & 1.000 & & & \\
\hline $\begin{array}{l}\text { M-329 (Mammoth } \\
\text { Mt.) }\end{array}$ & $<0.900$ & $<0.900$ & $<0.900$ & 0.913 & 0.900 & $<0.900$ & 0.904 & $<0.900$ & $<0.900$ & $<0.900$ & $<0.900$ & 0.928 & 0.956 & 0.949 & 1.000 & & \\
\hline
\end{tabular}

${ }^{1}$ Coefficients greater than 0.94 are highlighted on color for the three proposed correlative tephra groups identified in this report.

- Monkey Rock-Owens Lake A tephra

Owens Lake B-Negit Causeway (Mono Lake) tephra A

- Mammoth Mountain-Owens Lake C - Negit Causeway (Mono Lake) tephra B

of bones of camels, horses, Columbian mammoth, bison, and at least 9 different species of snail. A Pleistocene age was assigned to both the bones and the shells. Metzger and others (1973) reported vertebrate fossils from the mud facies north of Ehrenberg, Arizona (fig. 2; locality 06-1106-3 in appendix 1). These included a probiscidian tusk nearly $2 \mathrm{~m}$ long (from a gravel bed), as well as remains of turtle, snake, lizard, bird, and rodents, as well as invertebrates. Metzger and others (1973) were not able to constrain the age of these fossils, other than to say they were Blancan (early Pliocene to early Pleistocene) or younger. Agenbroad and others (1992) summarized the discoveries of mammoths along the lower Colorado River valley, including Mammuthus meridionalis, a species that lived in the area in early Pleistocene time; however, the stratigraphic contexts of these mammoths are not certain. Remains of an extinct pronghorn Capromeyrx sp. collected from valley-margin beds that we correlate to the stratigraphic position of the Chemehuevi Formation were identified by C.A. Repenning in an internal 1962 USGS report that suggested it may be older than late Pleistocene in age. Fossil mollusk and ostracodes that we have collected and identified are not age diagnostic, but all are consistent with a late Pleistocene age.

Magnetostratigraphy provides some limited age-related information. Normal polarity of oriented samples of finegrained sediment from the Chemehuevi Formation near Blythe (Bell and others, 1978) and in Cottonwood Valley (Lundstrom and others, 2008) demonstrate that the sampled sections are younger than the most recent geomagnetic reversal (780 ka). Kukla (1975) reported that six samples from 
two wells near Blythe had reversed polarity; however, the stratigraphic context of these samples is not known, and no justification is given for their assignment to their Chemehuevi-equivalent unit, so we suspect that these reversed samples represent sediments from stratigraphic unit(s) older than the Chemehuevi Formation.

As part of studies for the proposed Sundesert Nuclear Power Plant, Lee and Bell (1975) examined the depositional history of the lower Colorado River, including the mud facies of the Chemehuevi Formation, which they referred to as "Qrd." To better constrain ages for river-laid and related deposits, a variety of techniques was applied: magnetostratigraphy (Kukla, 1975), radiocarbon dating of wood (Fugro, Inc., 1975), uranium-series dating of pedogenic carbonates ( $\mathrm{Ku}, 1975)$, and amino acid racemization techniques used on vertebrate fossils (Bada, 1975). These results included a sample from a fossil probiscidian tusk lacking measurable radiocarbon, which they interpreted as being older than $40 \mathrm{ka}$, and minimum ages from amino-acid racemization analysis of the tusk as well as seven other vertebrate fossils from fossil localities near Ehrenberg discovered by Metzger and others (1973). Because the tusk was found to contain some modern amino acid contamination, and because it could not be dated independently using radiocarbon, the analysis did not have an adequate calibration sample. Thus, Bada (1975a) concluded that the ages obtained were minimum ages, and that the deposits must be older than $10-84$ $\mathrm{ka}$ as in table 4 . The relative ages of deposits dated as part of the Sundesert project were generally consistent with the stratigraphy described by Metzger and others (1973). The combined data led Lee and Bell (1975) to conclude that the Qrd sediments were deposited sometime between 700,000 and 80,000 years ago, and likely are older than $250 \mathrm{ka}$. Later, Bell and others (1978) reexamined a proboscidian tusk from the deposits using $\mathrm{Th}^{230} / \mathrm{U}^{234}$ and $\mathrm{Pa}^{231} / \mathrm{U}^{235}$ methods, obtaining an average age of $102 \pm 7 \mathrm{ka}$, and refined the age estimate for the Chemehuevis formation of Longwell (1936) to 100200 (?) ka.

Within the framework of the Vidal nuclear-site project, Bull (1975) conducted a geomorphic tectonic analysis of the area around Parker. He identified and mapped six timestratigraphic alluvial fan units graded to different base levels, which he presumed related to periods of temporary stability of the Colorado River. He distinguished them and estimated their ages based on similarity of soil profiles to soil profiles that had been dated in New Mexico. On the basis of the lack of faulted beds in these units, along with geomorphic observations of the sinuosity of mountain fronts, Bull (1975) concluded that the area must have been tectonically inactive during late Pleistocene time. The geologic map of the area (Dickey and others, 1980) does not distinguish the Colorado River deposits that are likely correlative to the Chemehuevi Formation, and thus it is not possible to correlate Bull's (1975) alluvial fan stratigraphy and age estimates to the Chemehuevi Formation. However, it is likely that the formation is most closely related in time to Bull's (1975) units Q2a and Q2b, the ages of which were estimated to be between 200 and $50 \mathrm{ka}$ and between 50 and $11 \mathrm{ka}$, respectively.

Radiocarbon evidence of age from the formation is limited. The wood fragment for which Blair (1996) reported a finite radiocarbon date from a wood fragment was found in the mud facies of the Chemehuevi Formation, on the west side of the river below the mouth of Black Canyon (appendix 1 , locality 05-127). The wood fragment occurred in a silt-rich layer at an approximate elevation of $280 \mathrm{~m}$ (fig. 10A). Its reported ${ }^{14} \mathrm{C}$ age of $35.1 \pm 0.4 \mathrm{ka}$ corresponds to a calibrated age of $40.4 \pm 0.4 \mathrm{ka}$ using an online version of the Fairbanks 0107 curve (Fairbanks and others, 2005). Owing to the poor preservation of the sample, Blair (1996) did not know whether the fragment represented transported stem material (and therefore would provide a maximum age) or post-depositional root material (and therefore a minimum age). In either case, a very small amount of carbon introduced much later, by groundwater or during handling of the sample, could bias the age of the material to a younger date. Wood recovered from two drill holes near Blythe and two near Yuma (from gravel underlying fine-grained Holocene or Chemehuevi Formation sediments) yielded infinite ages (Metzger and others, 1973; Olmsted and others, 1973). Another wood fragment from gravel that underlies the fine-grained sediments near Yuma that we include in the Chemehuevi Formation yielded an unpublished radiocarbon date (F. Croxen, Arizona Western College, Yuma, Ariz., written comm., 2008) that calibrates (Fairbanks and others, 2005) to $46 \pm 1 \mathrm{ka}$. In summary, the available radiocarbon information suggests that the age of the formation is near or beyond the maximum age detectable with the $\mathrm{C} 14$ dating method, approximately $40 \mathrm{ka}$.

Lundstrom and others (2008) reported eight ages obtained using luminescence techniques. Their samples were collected from the mud facies in Cottonwood Valley and at Yuma (fig. 2 ), and from a tributary facies of the formation in Las Vegas Wash (fig. 14A). They obtained ages between about 30 and 80 ka (table 4), depending on their assumptions about the moisture history of their samples (the lower range of dates assumed dry conditions, and the older ages assumed saturated conditions). However, for a given assumption about the moisture history, the dates were fairly close to one another, suggesting to those authors that the sampled sediments were deposited within several millenia. In addition, Lundstrom and others (2008) conducted uranium-series dating on carbonate clast coatings on cemented gravels below the Chemehuevi Formation and on gravels inset into the mud and sand facies of the Chemehuevi Formation, which they interpreted as sediments deposited as the river was incising the Chemehuevi fill. The sub-Chemehuevi Formation cemented gravel yielded dates of $\sim 142$ and 167 ka. Their dating of clast coatings on the inset gravels yielded ${ }^{230} \mathrm{Th}$ ages ranging from 32 to $60 \mathrm{ka}$, and they concluded that downcutting to these terrace levels quickly followed the deposition of the fine-grained parts of the Chemehuevi Formation. They interpreted their results to record aggradation of what we here assign to the Chemehuevi Formation through $60 \mathrm{ka}$, followed by its incision $\sim 60$ to $50 \mathrm{ka}$. 
In summary, varied dating techniques applied to the Chemehuevi Formation have yielded a wide range of ages, but most constrain the age of the sampled sediments to the late Pleistocene, likely between 35 and $80 \mathrm{ka}$. Judging from evidence that the formation may have accumulated rapidly (Lundstrom and others, 2008), this wide range of ages probably reflects uncertainty in geochronology, or the mistaken stratigraphic assignment of sampled sediments, and likely does not indicate that the formation was deposited over such a long period of geologic time. Additional geochronology combined with carefully documented stratigraphy and mapping could better constrain the age of the Chemehuevi Formation and correlate the deposits to specific climatic or geologic events in the history of the Colorado River watershed.

\section{Tephra Correlations and Age Constraints}

The presence of tephra layers in the Chemehuevi Formation provides an opportunity to apply tephrochronologic correlation to better constrain the age of the formation. Volcanic eruptions may produce ash containing glass shards with a distinctive geochemical fingerprint that is relatively consistent over the entire fallout area (Sarna-Wojcicki, 2000). If the ash(es) in the Chemehuevi Formation can be identified and have been dated directly, or if correlative ashes can be identified elsewhere where their age is better constrained, then the tephra horizons can provide additional age control for the formation.

\section{Correlation Among Tephra Layers in the Formation}

The four samples associated with the Chemehuevi Formation are similar to one another, as measured by their similarity coefficients (Borchardt, 1974). Compared with the Monkey Rock locality, the other three samples have coefficients of $0.98,0.96$, and 0.94 (table 3 ). Table 5 is a correlation matrix showing similarity coefficients among the samples from the Chemehuevi Formation and chemically similar tephra layers elsewhere in the southwestern United States. Among the samples from the Chemehuevi Formation, the two upstream samples (H05WB and 51005-6) are the most similar. The similarity coefficient of 0.98 makes them best matches to one another from among the $>6,000$ sample database compiled by the USGS Tephrochronology Project. They are as similar as replicate samples from the same ash bed and are therefore correlative. This tephra bed - subsequently referred to here as the Monkey Rock tephra bed - constitutes an important marker horizon in the Chemehuevi Formation.

The correlations of the other two samples collected from the Chemehuevi Formation (DM-06-1107-12 and DM-061222-2) are less certain, although they are more similar to the Monkey Rock tephra bed than most other tephras that have been analyzed (similarity coefficient of 0.97 ; table 3 ). They are similar enough that they almost certainly are from the same volcanic source area, but it is possible they may relate to different eruptive events, and thus, there may be two or three separate tephra layers represented among the four sites.

In particular, the sample from the Fort Mojave Indian Reservation (sample DM-06-1222-2 (pop 2)) may not correlate with the other three. The $\mathrm{Si}, \mathrm{Fe}$, and $\mathrm{Mn}$ contents of the Fort Mojave sample are distinctively lower than the rest. In addition, although alkalies ( $\mathrm{Na}$ and $\mathrm{K}$ ) are easily exchanged after deposition and therefore not usually diagnostic, both $\mathrm{Na}$ and $\mathrm{K}$ are higher in the Fort Mohave sample, suggesting the difference is related to the primary composition of the ash, rather than reflecting secondary alteration. Furthermore, the Fort Mojave tephra layer was found in a different stratigraphic position than the others, as it locally underlies the Chemehuevi Formation (table 3), whereas the other samples are contained within the formation. However, all four samples of tephra obtained from the Chemehuevi Formation correlate well with a sample from southeastern Nevada (CKS(WS)-1; similarity coefficients range from 0.98 to 0.96 ), so the glass of this particular eruption may have been variable enough to explain some or all of the differences among the samples.

\section{Mammoth Mountain Source Area}

On the basis of geochemical and stratigraphic evidence, we propose that these tephra were derived from the Mammoth Mountain dome complex, a silicic dome cluster on the southwestern periphery of the Long Valley Caldera, in the eastern Sierra Nevada (fig. 21). The Long Valley region was active throughout late Pleistocene time and produced numerous ash plumes that deposited tephra layers in the western Great Basin. The locus of volcanic activity in the Long Valley region has migrated over time through six spatially, chemically, and temporally distinct centers of magmatism; these range in age from late Pliocene to late Holocene (Hildreth, 2004). Prior to the start of volcanism in the Mono Craters $\sim 50 \mathrm{ka}$, the main focus of volcanic activity in the Long Valley region was in the Mammoth Mountain area. There were at least 25 lava dome emplacement eruptions in the Mammoth Mountain area, all of which would have been accompanied by tephra falls beyond the Long Valley area (W. Hildreth, USGS, oral comm, 2007). These lavas have radiometric ages ranging from $111 \pm 2$ to $57 \pm 2$ ka (Ring, 2000; Hildreth, 2004), and the most voluminous units near the source were extruded during the last part of this interval. At least half the lavas at Mammoth Mountain are younger than about $75 \mathrm{ka}$, and "all but a few are younger than 90 ka" (W. Hildreth, USGS, oral commun., 2009).

To test for chemical affinities supporting a connection between the Chemehuevi tephra layers and a Mammoth Mountain source area, two samples of proximal airfall pumice from Mammoth (samples provided by W. Hildreth, USGS) were analyzed by the USGS Tephrochronology Project. M-329, a proximal fallout Mammoth Mountain pumice fragment dated directly at $88 \pm 2$ ka using the ${ }^{40} \mathrm{Ar}-{ }^{39} \mathrm{Ar}$ method 


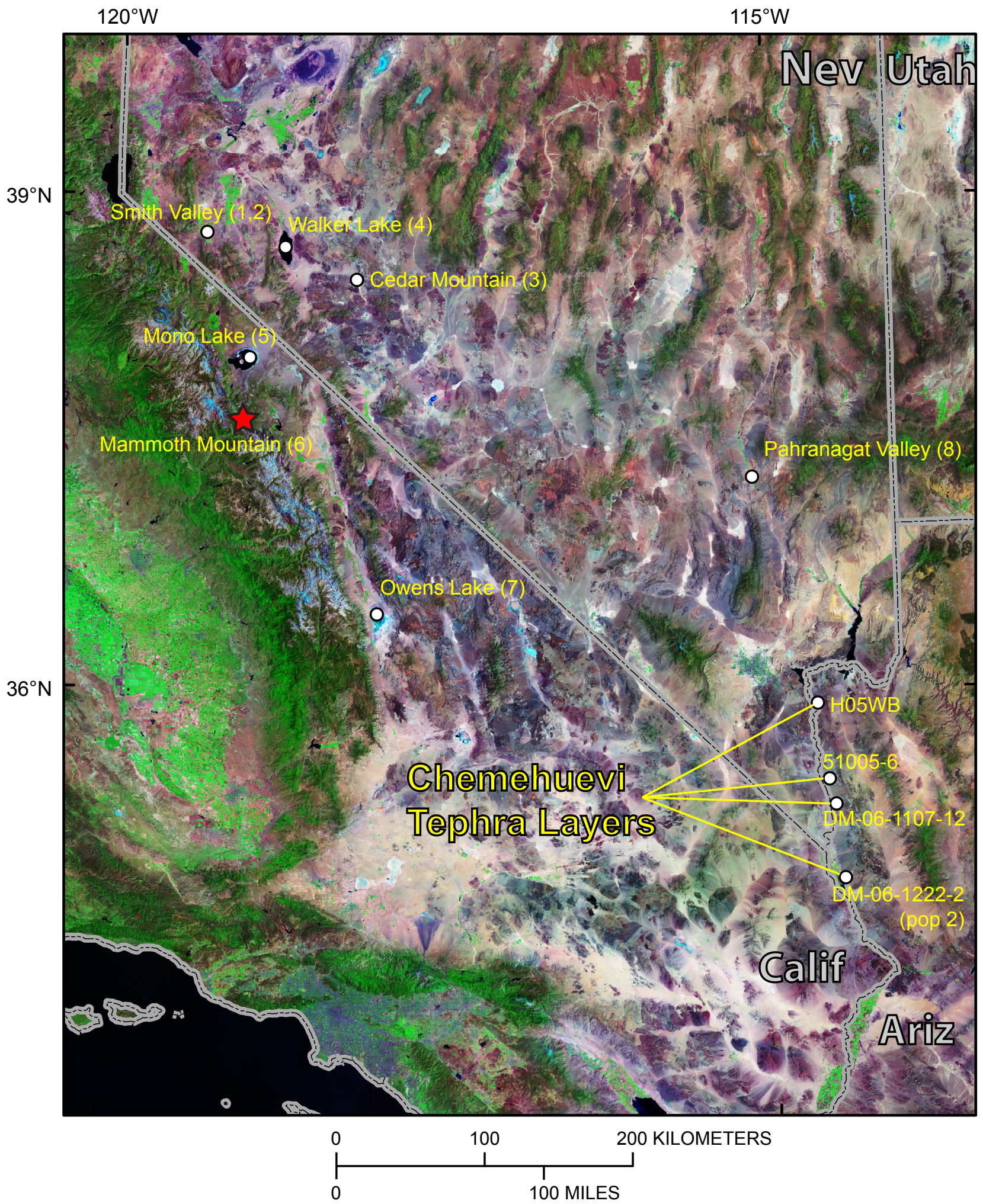

Figure 21. Satellite image of the southwestern United States, showing locations of tephra layers in and under the Chemehuevi Formation, location of Mammoth Mountain (red star), the putative source area for tephra, and the locations where other chemically similar tephra layers have been found. Numerals in parentheses refer to the numbered sections in the correlation diagram of figure 22. Landsat 4/5 TM $30 \mathrm{~m}$ data downloaded from University of Washington web site (accessed August 8, 2009 at http://gis.ess.washington.edu/data/raster/GlobalData/GeoCover1990). 
of dating. Sample M-179 is more distal than M-329 but likely relates to the same eruptive event. The two samples are from the only known exposures of proximal fallout, owing to multiple cycles of glacial erosion and to the scree-covered slopes of the lava domes (W. Hildreth, oral commun., 2007).

All four samples from the lower Colorado River were probably derived from the Mammoth Mountain source area, as indicated by a broad chemical similarity to samples M-329 and M-179 (table 5). The tephra layers associated with the Chemehuevi Formation are not similar enough to the Mammoth Mountain samples to suggest they are from the same eruptive unit, as most of the similarity coefficients are below 0.900 (table 5). However, one of the samples from the Chemehuevi Formation (DM-06-1222-2(pop 2)) is among the best matches (similarity coefficient of 0.9125) to the Mammoth pumice sample M-329 from the entire database of more than 6,000 samples (table 6). The close affinities among the four Chemehuevi Formation tephra samples suggests that the four were almost certainly derived from the same volcanic source area, so if one of the samples is from Mammoth, it is likely that the rest are also from Mammoth. In addition, similarity coefficients between the second Mammoth pumice sample (M-179) and three of the Chemehuevi Formation samples (DM-06-1222-2(pop 2), 51005-6, and H05WB-3) are 0.921, 0.917, and 0.900 - suggesting they are probably from the same source area. The percentages of $\mathrm{SiO}_{2}$ in the four samples are consistent with a Mammoth Mountain correlation - based on the $\mathrm{SiO}_{2}$ content of the Mammoth pumice samples and the bulk composition range of the Mammoth lava domes, the expected range of $\mathrm{SiO}_{2}$ in ash derived from Mammoth should be roughly 71 to 76 percent (W. Hildreth, written commun., 2009) - bracketing the $\mathrm{SiO}_{2}$ range of the four tephra samples ( 72.7 percent to 74.1 percent). On the basis of chemistry alone, we can only conclude that it is reasonable but not certain that Mammoth Mountain is the source of the tephra associated with the Chemehuevi Formation. However, as discussed next, the list of best matches to the Mammoth Mountain pumice contains many samples that are associated chemically or stratigraphically to the samples from the Chemehuevi Formation (samples highlighted in yellow on table 6), and some of these tephras have also been inferred to have been derived from Mammoth Mountain.

\section{Stratigraphic Context of Chemically Similar Tephra Layers Elsewhere}

Samples of the Monkey Rock tephra in the Chemehuevi Formation are also similar to some other tephra layers sampled in the Basin and Range. Figure 22 is a diagram showing the stratigraphic context of possibly related tephra at nine locations in the Basin and Range, and table 5 shows the similarities among the three sets of chemically similar tephra depicted in the correlation diagram. All the samples from the lower Colorado River valley match well (table 5; fig. 21) with tephra samples found in pre-Lake Lahontan alluvium in Pahranagat Valley, southeastern Nevada (sample CKS(WS)-1) (fig. 22). They also match reasonably well (similarity coefficient $>0$.
90) with tephras sampled in lacustrine sediments of the Owens Lake, Calif., core (OL92-1(41.5 m)); lacustrine sediments in the causeway between Black Point and Negit Island in Mono Lake, Calif. (KRL-71082(II-5)); lacustrine sediments of about the same age in the Walker Lake, Nev., core (WL4-26(66.4)); shoreline sands at Artesia Lake, Smith Valley, west-central Nevada (AL98-51A); and pre-Lahontan lacustrine sediments in the same area (SGW-SV-2008) (fig. 22). On the basis of their stratigraphic context relative to fluctuating lake levels and within dated cores, all the tephra layers similar to those in the Chemehuevi Formation were deposited during Marine Oxygen Isotope (MOI) stage 4 (74 to $59 \mathrm{ka}$ ago), a period of generally high lake levels before the existence of Lake Lahonton in MOI stage 2 .

Two separate tephra samples in the Owens Lake core, taken at a depth of $\sim 41.5 \mathrm{~m}$, gave somewhat different results from one another (table 5). One sample, OL92-1(41.4 m) B, was chemically more similar to the samples from the Mono Lake Causeway (KRL-71082(II-5)) and from Walker Lake (WL4-26(66.4 m)) than the other sample, OL92-1(41.5 m) A. A tephra layer underlying the above mentioned set of inferred correlative tephra samples is present in both the Owens Lake core (OL92-1(pop2)(47.9 m)) and in the causeway secion at Mono Lake (KRL71082(II-3)) (purple layers in fig. 21). These samples correlate reasonably well with two closely superposed tephra layers in alluvium in the Cedar Mountain area of central Nevada (1-JWB-CM-3 and 1-JWB-CM-2). At the latter locality, the tephra layers are overlain by an early Wisconsinan soil (Bell and others, 1999) (fig. 22). Samples of this lower tephra layer are chemically most similar to the two tephra samples from the Mammoth Mountain area (M-329 and M-179), a unit dated at $88 \mathrm{ka}$.

A tephra layer in the Mono Lake causeway (KRL710822(II-4) is situated between the two Mammoth Mountain-like tephra layers in that section (orange layer in fig. 22). This layer is different in chemical composition from all the Mammoth Mountain-like tephra samples and most closely resembles, but does not match, tephra erupted from the Mono Craters. We suspect that this is an older, "proto-Mono Craters" tephra layer. It and the layers above and below it in the causeway section dip to the north, underneath the younger tephra layers derived from Mono Craters exposed in the Wilson Creek section to the north and west, on the north shore of Mono Lake (Lajoie, 1968). The Mono Craters-derived tephra layers range in age from $\sim 14$ to $42 \mathrm{ka}$ (Benson and others, 1999). Tephra of sample KRL710822(II-4) matches a sample in the Walker Lake core (WL4-26(66.5 m)) (orange layers in fig. 22), providing an independent correlation between these two sections and corroborating the correlation of the overlying tephra layer between Walker Lake (WL4-26(66.4 m) and the Mono Lake causeway (KRL71082(II-5)).

\section{Summary of Age Control}

All four tephra layers found beneath and within the Chemehuevi Formation can be placed into a reasonably consistent stratigraphic context, and estimates of their age can be 
Table 6. Geochemistry of closest chemical matches ${ }^{1}$ to dated ${ }^{2}$ proximal Mammoth Mountain pumice.

[Samples highlighted yellow are those relating to tephra layers in the Chemehuevi Formation and whose stratigraphic context is shown in figure 22]

\begin{tabular}{|c|c|c|c|c|c|c|c|c|c|c|c|}
\hline & $\begin{array}{l}\text { USGS Tephrochronology } \\
\text { Laboratory Sample Number }\end{array}$ & $\mathrm{SiO}_{2}$ & $\mathrm{Al}_{2} \mathrm{O}_{3}$ & $\mathrm{Fe}_{2} \mathrm{O}_{3}$ & IgO & MnO & $\mathrm{CaO}$ & $\mathrm{TiO}_{2}$ & $\mathrm{Na}_{2} \mathrm{O}$ & $\mathrm{K}_{2} \mathrm{O}$ & $\begin{array}{l}\text { Similarity } \\
\text { Coefficient }\end{array}$ \\
\hline 1 & M-329 T549-2 & 74.95 & 15.59 & 1.27 & 0.11 & 0.11 & 0.46 & 0.19 & 3.27 & 4.05 & . \\
\hline 2 & M-179 T549-1 & 75.04 & 15.51 & 1.26 & 0.11 & 0.12 & 0.49 & 0.17 & 3.17 & 4.14 & 0.9699 \\
\hline 3 & 1-JWB-1-CM-3 T154-2 & 72.87 & 14.90 & 1.29 & 0.12 & 0.12 & 0.48 & 0.20 & 5.10 & 4.92 & 0.9562 \\
\hline 4 & 1-JWB-1-CM-2 T154-1 & 72.82 & 14.97 & 1.30 & 0.12 & 0.11 & 0.50 & 0.20 & 5.06 & 4.92 & 0.9492 \\
\hline 5 & OL92-1 (47.90M) POP\#2 T149-1 & 72.27 & 15.70 & 1.06 & 0.11 & 0.10 & 0.49 & 0.20 & 5.21 & 4.86 & 0.9468 \\
\hline 6 & 3/30/98 T460-7 & 74.13 & 13.94 & 1.39 & 0.11 & 0.06 & 0.42 & 0.18 & 3.48 & 6.29 & 0.9429 \\
\hline 7 & UCSB-FS-89-6-6BC & 73.00 & 14.93 & 1.11 & 0.11 & 0.10 & 0.49 & 0.21 & 5.20 & 4.86 & 0.9415 \\
\hline 8 & 9-11-85-5Р Т276-1 & 74.14 & 14.92 & 1.22 & 0.11 & 0.11 & 0.41 & 0.23 & 4.61 & 4.25 & 0.9374 \\
\hline 9 & K-98-5-7c T441-2 & 74.18 & 13.81 & 1.46 & 0.11 & 0.08 & 0.40 & 0.19 & 3.31 & 6.46 & 0.9358 \\
\hline 10 & FLV 3.13 (9.89m) LoSi T310-9 & 72.48 & 15.47 & 1.12 & 0.13 & 0.12 & 0.47 & 0.21 & 5.21 & 4.81 & 0.9285 \\
\hline 11 & KRL-71082 (II-3) (592) T58-3 & 72.65 & 14.86 & 1.27 & 0.12 & 0.00 & 0.49 & 0.24 & 5.26 & 5.11 & 0.9283 \\
\hline 12 & FLV-83-HT T192-2 & 74.11 & 13.89 & 1.19 & 0.10 & 0.09 & 0.37 & 0.19 & 3.84 & 6.21 & 0.9217 \\
\hline 13 & EB-ASF-BM T562-2 & 75.54 & 14.61 & 1.13 & 0.11 & 0.08 & 0.52 & 0.23 & 1.94 & 5.83 & 0.9216 \\
\hline 14 & FLV-229-CuC T344-5 & 73.00 & 14.90 & 1.17 & 0.13 & 0.10 & 0.50 & 0.21 & 4.87 & 5.11 & 0.9203 \\
\hline 15 & TF30A4 T274-5 & 74.70 & 13.98 & 1.05 & 0.10 & 0.11 & 0.49 & 0.20 & 3.74 & 5.63 & 0.9197 \\
\hline 16 & EB-LP-3 T565-3(pop1) & 74.75 & 13.65 & 1.05 & 0.11 & 0.05 & 0.53 & 0.20 & 2.48 & 7.18 & 0.9196 \\
\hline 17 & JS-5-3-08-1 T572-1(pop1) & 77.78 & 12.84 & 1.29 & 0.09 & 0.04 & 0.51 & 0.19 & 2.87 & 4.38 & 0.9153 \\
\hline 18 & JRK-D & 73.04 & 14.99 & 1.19 & 0.14 & 0.09 & 0.50 & 0.21 & 4.86 & 4.99 & 0.9139 \\
\hline 19 & 7-8 REDO 4/95 & 76.74 & 12.57 & 1.26 & 0.09 & 0.03 & 0.49 & 0.20 & 3.47 & 5.15 & 0.9137 \\
\hline 20 & etb-1-155 WALCUTT M. Perkins 6 & 76.89 & 12.21 & 1.25 & 0.09 & 0.04 & 0.50 & 0.19 & 3.40 & 5.42 & 0.9134 \\
\hline 21 & DM-06-1222-2(рор2) T546-4 & 72.69 & 15.16 & 1.27 & 0.15 & 0.08 & 0.54 & 0.18 & 5.03 & 4.91 & 0.9125 \\
\hline 22 & FLV-115-WW T182-6 & 77.09 & 12.37 & 1.27 & 0.08 & 0.01 & 0.47 & 0.19 & 2.89 & 5.63 & 0.9119 \\
\hline 23 & RDO-091106g-djk T54 & 76.10 & 13.42 & 1.01 & 0.12 & 0.07 & 0.42 & 0.19 & 2.44 & 6.24 & 0.9118 \\
\hline 24 & $\mathrm{AH}-4($ & 75.24 & 13 & 1 & 0.11 & 0.06 & 0.50 & 0.17 & 4.49 & 6 & 065 \\
\hline 25 & EB-ASH-28a T559-7 & 73.98 & 14.07 & 1.14 & 0.10 & 0.08 & 0.55 & 0.21 & 2.66 & 7.19 & 0.9062 \\
\hline 26 & TULELAKE-264, T69-7 & 76.16 & 13.00 & 1.24 & 0.11 & 0.05 & 0.62 & 0.17 & 3.93 & 4.72 & 0.9052 \\
\hline 27 & FLV-105-WW T196-1 & 74.57 & 13.81 & 1.21 & 0.09 & 0.10 & 0.38 & 0.2 & 4.35 & 5.28 & 0.9046 \\
\hline 28 & JS-QUI-3 T573-1 & 78.68 & 12.69 & 1.28 & 0.08 & 0.05 & 0.49 & 0.19 & 3.04 & 3.51 & 0.9041 \\
\hline 29 & EL-47-RM T336-8 & 77.13 & 12.16 & 1.23 & 0.09 & 0.04 & 0.49 & 0.18 & 3.11 & 5.59 & 0.9041 \\
\hline 30 & HC-11 & & 12.22 & 1.32 & 0.09 & 0.04 & 0.49 & 0.2 & 2.90 & 5.41 & 0.9037 \\
\hline 31 & AL98-5 & 73.18 & 14.9 & 1.41 & 0.13 & 0.09 & 0.62 & 0.19 & 4.38 & 5.1 & 0.9035 \\
\hline 32 & EL-65-RM T348-3 & 73.5 & 14.26 & 1.11 & 0.09 & 0.1 & 0.38 & 0.19 & 3.71 & 6.66 & 0.9023 \\
\hline 33 & EB-ASH-28cl T561-1(pop1) & 75.91 & 14.4 & 1.13 & 0.12 & 0.09 & 0.53 & 0.23 & 1.98 & 5.61 & 0.9019 \\
\hline 34 & OL92-1003 T270-6 & 73.85 & 14.38 & 1.07 & 0.09 & 0.11 & 0.47 & 0.22 & 5.19 & 4.62 & 0.9018 \\
\hline 35 & CKS(WS)-1 T348-2 & 72.18 & 15.5 & 1.37 & 0.15 & 0.09 & 0.55 & 0.18 & 4.97 & 5.02 & 0.9002 \\
\hline 36 & FLV-116-WW T182-7 & 76.89 & 12.4 & 1.31 & 0.09 & 0.02 & 0.49 & 0.21 & 2.96 & 5.63 & 0.9002 \\
\hline
\end{tabular}

${ }^{1}$ Based on similarity analysis for geochemistry of samples in USGS Tephrochronology database. Similarity analysis excludes $\mathrm{MnO}$ and the alkalies $\mathrm{Na}_{2} \mathrm{O}$ and $\mathrm{K}_{2} \mathrm{O}$. $\mathrm{MnO}$ was determined in one early run group to not be important to the data evaluation here.

${ }^{2}$ Proximal pumice fragments of samples M-329 and M-179 are from eruption dated at 88 $\pm 2 \mathrm{ka}$ using Ar-Ar geochronology; sample provided by W. Hildreth, USGS.

derived from several sources: (1) dated horizons in the Owens Lake and Walker Lake cores; (2) the age range of the volcanic source rocks, inferred to be derived from Mammoth Mountain; and (3) correlations with other sections, such as that at Mono Lake, Calif., which ties the relevant sections together (fig. 22).

All correlations and associated stratigraphic and soils data point to an early Wisconsinan (MOI stage 4) age for the tephra layers associated with the Chemehuevi Formation. Moreover, constraints from the Walker Lake core provide an age estimate of $\sim 70 \mathrm{ka}$ and from the Owens Lake core provide an age estimate of $\sim 74 \mathrm{ka}$ for the levels at which WL4-26 (66.4 m) and OL92-1 $(41.5 \mathrm{~m})$ are situated, suggesting that the correlation of chemically similar Monkey Rock tephra is of the same age. Thus, the most likely age for the Monkey Rock tephra is approximately $72 \mathrm{ka}$. If the complex of Monkey Rock-Walker
Lake-Owens Lake tephra layers (yellow in fig. 21 and table 5) are not correlative, a consistent broader age range can be gleaned from the Walker Lake core ( $<50$ to $80 \mathrm{ka}$ ), the Owens Lake core (60 to $90 \mathrm{ka}$ ), and the age range of the Mammoth Mountain volcanic center ( $57 \pm 2 \mathrm{ka}$ to $111 \pm 2 \mathrm{ka}$, with a higher likelihood of being closer to the latter part of this age range). In other words, even if the correlations with the tephra in Owens Lake and in Walker Lake are not precisely correct, multiple stratigraphic constraints provide a broader constraining age range for the Monkey Rock tephra that mostly coincides with early Wisconsinan time and MOI stage 4, which lasted from about $74 \mathrm{ka}$ to $59 \mathrm{ka}$ (Martinson and others, 1987)

Additional stratigraphic evidence supports a MOI stage 4 age for tephra similar to those in the Chemehuevi Formation. The Mammoth Mountain volcanics are no younger than 
Mono Lake, Mammoth Mt.,

Smith Valley, Valley,

Nev. Artesia Lake,

(outcrop)

$\mathrm{Nev}^{2}$

(outcrop)

Cedar Mt.

$\mathrm{Nev}^{3}$

Walker Lake,

Calif. ${ }^{5}$

(outcrop)

$\mathrm{Nev}^{4}{ }^{4}$

git cause-

(outcrop)

(volcanic

source area)

(outcrop)
Owens Lake,

Calif. $^{7}$
(core)

Valley, Nev.

(core)

Ariz.

(outcrop)

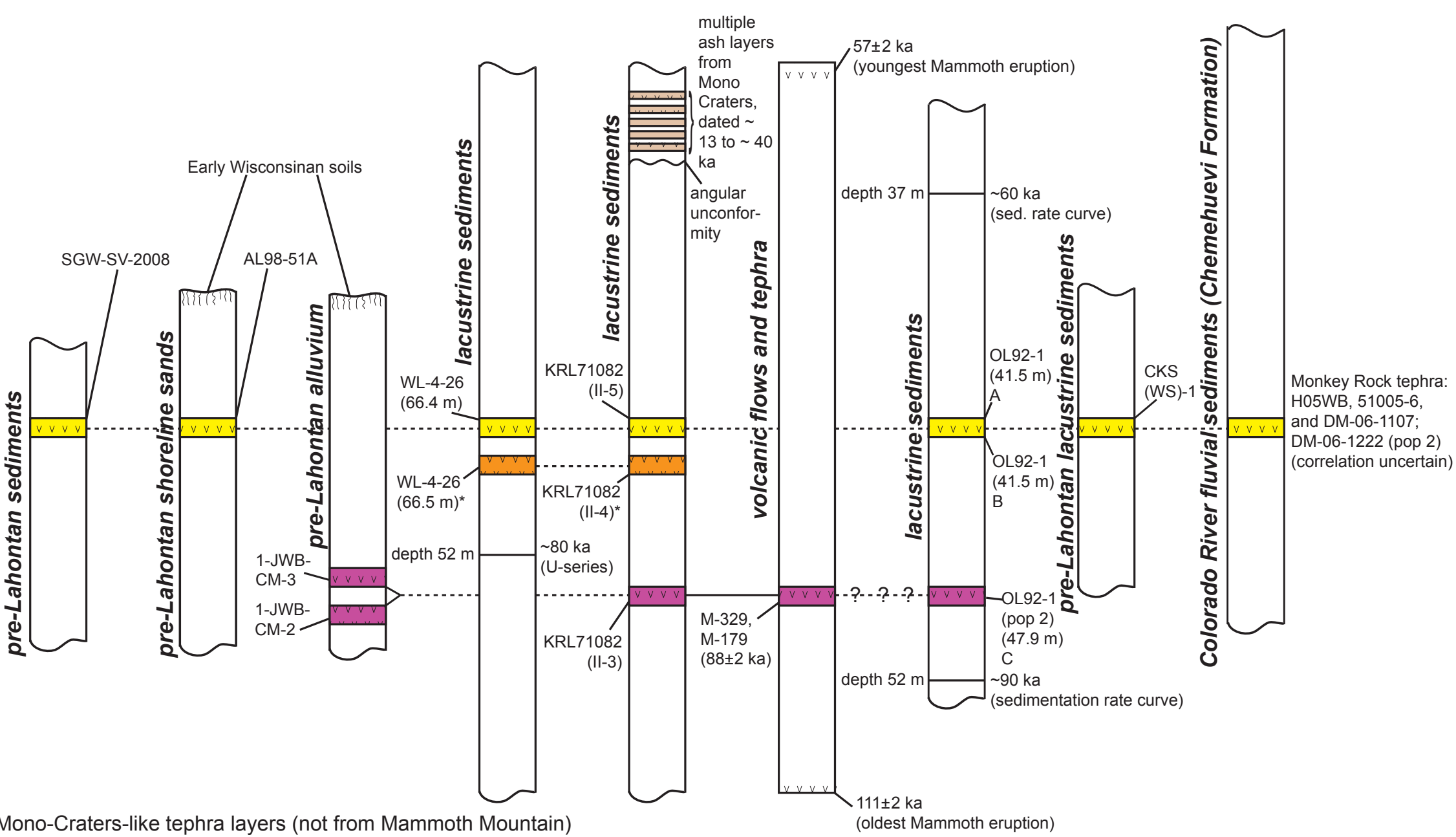

Figure 22. Correlation of tephra layers and stratigraphic context of similar tephra found elsewhere in the Basin and Range Province. Numbered references: (1) Steven Wesnousky, U. of Nevada, written commun., 2008; (2) Stauffer, 2003; (3) Bell and others, 1999; (4) Sarna-Wojcicki and others, 1988; (5) Lajoie, K.R., written commun. to Sarna-Wojcicki, 1982; (6) W. Hildreth, USGS, written comm., 2009; (7) Sarna-Wojcicki and others, 1997; (8) K. Cupp, USGS, written commun., 1996; (9) this report. On the basis of possibly correlative tephra layers in Walker Lake and Owens Lake cores, estimated age of tephra layer referred to here as the Monkey Rock tephra (yellow shading on diagram) is 72 ka. Likecolored layers in diagram refer to interpreted correlative tephra layers. 
about $57 \mathrm{ka}$. In addition, the complex of Mammoth-like tephra layers shown in figure 22 is unlikely to be younger than MOI stage 4 because, in the Mono Lake section, they are overlain on an angular unconformity by tephra erupted from the Mono Craters ranging in age from $\sim 14$ to $45 \mathrm{ka}$ (late MOI stage 3 and stage 2). In addition, the Mammoth-like tephra layers are unlikely to be older than MOI stage 4, because the Mammoth Mountain volcanics are no older than $111 \mathrm{ka}$, and furthermore, there are no soils above the Mammoth Mountain-like tephra layers that have thick, well-developed profiles indicative of MOI stage 5 (Sangamonian).

\section{Interpretations and Discussion}

We interpret that the Chemehuevi Formation was deposited in a variety of fluvial and flood plain lake settings within the lower Colorado River and tributary valleys during a single, late Pleistocene aggradational episode, during which the river filled its valley with as much as $150 \mathrm{~m}$ of dominantly sand-, silt- and clay-sized sediment. The comparative steepness of the longitudinal profile, along with fossil evidence (described below) rule out the possibility that the formation was deposited in a single large lake, as envisioned by Longwell (1936, 1945, 1963). Instead, the aggradation was caused by an increase in the ratio of sediment supply to transport capacity for sand-sized sediment in the lower Colorado River leading to long-term aggradation. The formation, containing abundant rounded quartz grains as well as thick mud sequences, consists of material inferred to be derived dominantly from erosion on the Colorado Plateau and deposited in fluvial and related environments in the valley during the most recent episode of aggradation in late Pleistocene time, most likely during the early part of Marine Oxygen Isotope (MOI) stage 4.

\section{Interpretation of Depositional Environments}

Aggrading alluvial valleys contain a variety of depositional environments, locally juxtaposing significantly distinct lithofacies. Each of the main facies described in section 4 is attributable to depositional environments that would be expected in a large, aggrading river valley responding to a surplus of upstream sediment supply.

\section{Mud Facies}

We interpret sediments of the mud facies as flood plain deposits. In this interpretation, each sand-mud couplet (fig. $10 B$ ) would represent a discrete layer deposited in a flood plain environment during a single overbank flood event. The sand parts of the couplets in places exhibit ripple crosslamination (fig. 10C) or horizontally laminated and bedded sand. These bedforms in fine to medium sand are characteristic of ripple or lower plane bed flow regimes, and indicate that these parts of the mud facies were deposited at flow velocities between 0.2 and $1 \mathrm{~m} / \mathrm{s}$ and flow depths between 0.2 and 0.5 m (for example, Miall, 2006). Such flow conditions are typical of relatively shallow flow on vegetated flood plains during overbank flooding and are not characteristic of either deep lake environments (as inferred by Longwell) nor the active channel bed of the Colorado River. The mud layers are dominated by clay- through silt-sized grains (fig. 9), material likely to be transported as washload and not deposited in the channel bed. Common evidence of decayed roots extending downward centimeters to decimeters below the base of overlying beds (for example, fig. 19B) is also consistent with a seasonally ponded flood plain environment.

Lenticular clay deposits (for example, fig. 10B) within the mud facies are probably filled in flood plain lakes and depressions. Some clay intervals are very light gray (Munsell color N8; fig. 10D), suggesting reducing conditions that would require prolonged ponding of water. Lenticular clay bodies in the Chemehuevi Formation have yielded some of the most significant fossils discovered in the formation. Near Ehrenberg, Ariz., Metzger and others (1973, p. G25) discovered fossilized remains of turtles, snakes, lizards, and birds in lenticular clay deposits.

Clay-rich intervals interpreted as flood plain lakes also contain invertebrate fauna, some of which may be diagnostic of particular ecological settings. Freshwater gastropods we collected from the mud facies of the formation were identified by C. Powell, II, (written comm., 2009) as Physidae (a family found in both permanent and temporary standing water) and Archiphysa(?) sp., or Haitia sp., which are found in a wide variety of aquatic habitats. From a site where mud-rich valley margin deposits are exposed, Taylor (1982) identified the freshwater snails Bakerlymrae cubensis (Phieffer) and Physovirgatta Gould, indeterminate Succinea(?) and the land snail Virtigo orata.

Ostracodes are also present in the mud facies. Ostracodes in a sample from a thick clay interval of the mud facies, 2 . $5 \mathrm{~km}$ southwest of Davis Dam (appendix 1, locality 05-137) were examined by J. Bright at Northern Arizona University. The sample yielded Limnocythere staplini, Candona sp. (rawsonoid-type), and fragments of Cypridopsis vidua. Limnocythere staplini generally live in springs and groundwater-fed wetlands. This species is an indicator species for water with a high-calcium to alkalinity ratio and has been found in modern off-channel wetland environments in the Colorado and Gila River valleys. Cypridopsis vidua is a spring and wetland species and is also common in areas with aquatic vegetation (J. Bright, Northern Arizona University, written comm., 2008). Clay-rich intervals containing freshwater aquatic fauna are diagnostic of ponded water and evaporative conditions, as in flood plain lake environments such as those that may have formed in abandoned channels of the aggrading Colorado River. Both perennial and ephemeral lakes occupying abandoned channels were a common feature of the pre-Hoover Dam flood plain environment (for example, Ives, 1861). We expect flood plain lakes were especially common in an aggrading valley, which was likely characterized by frequent channel migration. Colorado River aggradation in the Holocene has 
also been linked to rapid formation and evolution of flood plain lakes (Malmon and others, 2009b).

\section{Sand Facies}

We interpret the sand facies (which also includes some minor gravel) as having been deposited in the main channel of the Colorado River or in proximal crevasse splay deposits during long-term fluvial aggradation. The high degree of sorting and rounding, the high quartz content, and the presence of fluvial bedforms, scattered river pebbles, and rare gravel or mud beds indicate that deposits of the sand facies were deposited within the active channel of the Colorado River. Exposures show a variety of fluvial sedimentary structures, including both ripple and dune-scale crossbedding, as well as horizontally laminated sand. Also present are low-angle, tabular crossbeds (fig. 11C), and rare trough crossbedding with curved bounding surfaces. These lithofacies reflect two- and three-dimensional dune bedforms, point bars, plane beds, and possibly sediment gravity flows - features typical of traction-dominated flows in large river channels (Miall, 2006). The sand facies includes locally abundant rhizoliths (fossilized roots and stems expressed as calcareous casts and tubes that cut across bedding planes, fig. $11 D$ ), demonstrating the vegetation grew when these deposits were not inundated. The aggrading river likely had a wide, braided channel planform, including topographic highs within the active channel system that were only inundated during floods.

\section{Rhythmite Facies}

The sedimentology and bedding structure of the rhythmite facies (fig. 13) in the Lake Mead area struck Longwell (1936) as being suggestive of "gigantic varves" (p. 1445). This layering led Longwell to hypothesize that the Chemehuevi sequence was deposited in a giant Pleistocene lake. He interpreted that the rhythmic layering of the formation was deposited in a delta at the head of a lake fed by the Colorado River, in which "each great flood would be recorded in a thick layer, consisting chiefly of sand grading upward into silt, with clay at the top to mark the succeeding low-water stage of the river" (Longwell, 1936, p. 1451).

The sedimentology of the rhythmite facies suggests at least two alternative possible interpretations of these beds that are consistent with a rapidly aggrading fluvial system. One interpretation is that they represent the deposits of crevasse splays on an aggrading flood plain. Crevasse splays form lenticular sand-dominated bodies on flood plains, due to the breaching of natural levees and the rapid overbank deposition of lobes of sandy material during floods. During and following the waning of floods, turbid water stranded on the flood plain can deposit a horizontal layer of washload-sized sediment (silt and clay). The sand parts of crevasse-splay deposits contain common trough crossbedding and ripple cross-lamination, as well as interbedded laminae of siltstone and mudstone.
Crevasse-splay structures have been interpreted in other ancient fluvial deposits, and may be virtually indistinguishable from lacustrine deltas (Miall, 2006), as they can also exhibit low-angle accretion surfaces that would represent lateral progradation of sand lobes. Such structural elements are common in meandering and anastamosed fluvial environments and occur in several of the fluvial sequences within sedimentary rocks of the Colorado Plateau, including the Moenkopi and Chinle Formations (Miall, 2006). Crevasse-splay deposition would be enhanced in an aggrading Colorado River, particularly within the Lake Mead area, where the valley widens and the gradient decreases (fig. 7). Sedimentation in the channel would tend to increase the elevation of the bed relative to the flood plain, increasing the probability that large lobes of sand-dominated material could be carried onto the flood plain in splays.

Some of the rhythmite facies may have been deposited within valley-marginal lakes formed as a result of damming of tributary mouths, as suggested by Lundstrom and others (2008). Rapid sedimentation along the Colorado River may have outpaced sedimentation in tributaries, leading to impoundments at tributary mouths. In the past half century, valley marginal lakes have formed in minor tributaries of the Colorado River as a result of deltaic sedimentation at the upstream ends of lakes formed by Hoover, Davis, Parker, and Imperial Dams (Malmon and others, 2009b). Sedimentation in lakes formed at the mouths of major and minor tributaries due to impoundment by sedimentation along the main stem could partially explain the existence of lacustrine-like beds of the Chemehuevi Formation in the context of an aggrading river system.

A sample from a thin limey mudstone layer interbedded with much thicker sand sequences in the rhythmite facies at Sandy Point yielded ostracodes. Limnocythere staplini and Potamocypris sp. were common, and Candona sp. (aff. rawsoni) was present but less common (J. Bright, Northern Arizona University, written comm., 2008). Limnocythere staplini, also found in the mud facies, is an indicator species for water with elevated calcium to alkalinity ratio. This species commonly lives in groundwater-fed springs and wetlands, occasionally in lakes, and has been found in flood plain lake settings adjacent to the Gila River. The genus Potamocypris is very common in wetlands and springs and sometimes along the margins of lakes, but not in deep lake settings, and the Candona likely represents a wetland or shallow lake setting. The sample lacks ostracodes associated with flowing water, such as Pelocypris and Ilyocypris, which are normally found in the beds of active rivers. Shallow, groundwater-supported wetland environments, as indicated by the ostracode evidence, likely existed on flood plains or in locations behind natural levees lining the aggrading Colorado River during periods of low flow.

As nearly all of the sediment of this facies is now submerged beneath Lake Mead, we were only able to examine a few outcrops. Although the lack of access to the mostly drowned rhythmite facies makes the nature of the depositional 
environment of the rhythmite facies uncertain, we interpret the rhythmite-facies deposits within the context of an aggradational episode.

\section{Tributary Facies}

Differences in the grain size, bedding structure, and color (fig. 14) of the tributary facies compared with deposits along the main stem Colorado River are partly attributable to different lithologic sources in their watersheds. The depositional environments along the lower parts of tributary valleys are also likely to have been different than those along the main stem of the Colorado River. For example, pale, gypsiferous mud interfingers with the Chemehuevi Formation near the mouth of Sacramento Wash (Howard and Malmon, 2007; K. Howard, unpub. mapping). A snail shell in the pale beds was tentatively identified as the freshwater genus Planorbella, which is common in paludal environments in the Basin and Range. This is a genus that lives in both permanent and ephemeral freshwater settings and tends to occur in bodies of water with a firm mud bottom, and high levels of decaying organic matter (C. Powell, II, USGS, written commun., 2009). The pale, gypsiferous mud transitions eastward, away from the Colorado River, into a sequence of interfingering mud, angular gravel, sand, and paleosols containing root casts. This latter facies sequence suggests a partly swampy environment along the margin of the Colorado River valley into which ancestral Sacramento Wash and smaller tributaries carried gravel, sand, and mud.

A likely explanation for paludal conditions at the mouths of major tributaries is that rapid aggradation of the Chemehuevi Formation along the main-stem Colorado River valley increased the base levels at the outlets of some tributary washes, possibly damming them. Above, we suggested the possibility that part of the rhythmite facies records similar depositional environments along minor tributaries. Lundstrom and others (2008) pointed out that comparable valley-mouth lakes formed along the late Pleistocene Mississippi River and the lower parts of major tributaries, including the Ohio and Wabash Rivers, following the sudden increase of sediment to the system caused by the melting of the Laurentide Ice Sheet (Shaw, 1911; Thornbury, 1950). Ponding near major tributary junctions could result in deposition of fine-grained sediment from mixed river and tributary sources at tributary mouths. High evaporation rates in these intermittently watered side-stream lakes could account for the abundant gypsum crystallizing out of these deposits, as in lower Sacramento Wash.

The environments recorded in the tributary facies may be evidence that the aggradation of the main stem occurred rapidly compared with local tributaries. This interpretation is consistent with the idea that the aggradational episode that led to the deposition of the Chemehuevi Formation was related to the introduction of a large amount of sediment to the system from upstream, primarily derived from the Colorado Plateau.

\section{Regional Stratigraphic Architecture and the Sand-Over-Mud Contact}

An interpretation of the regional stratigraphic arrangement of the different facies of the Chemehuevi Formation will help delineate the formation and may also help interpret the set of events that it records. Contrasting concepts of the formation's stratigraphic architecture have developed from studies in different areas along the valley and are not necessarily mutually exclusive. These varying concepts, including our preferred model of the stratigraphic architecture, are summarized in figure 6.

Longwell's (1936) observations of no apparent erosional breaks in the formation in the Lake Mead area led him to infer that the mud and sand accumulated in a continuous aggradational episode, to a thickness of $130 \mathrm{~m}$ (fig. 6A). The contrasting model of Metzger and others (1973), is based on their observations in areas from Mohave to Cibola Valleys that the sand facies cuts into the underlying mud facies. Those authors asserted that the mud facies first accumulated during an episode of fluvial aggradation, and then the sand facies was deposited on a single regional erosional unconformity during subsequent degradation (fig. 6B). Because the sand facies is locally at least $50 \mathrm{~m}$ thick (fig $11 \mathrm{~A}$ ), this model implies that at least that much sand accumulated during temporary halts or reversals in downcutting. A third concept of the alluvial stratigraphy, proposed by Faulds and others (2004) and House and others (2005b), on the basis of their detailed mapping near Davis Dam, inferred that the deposits we include in the formation consist of several inset sequences of mud and sand, representing multiple cycles of late Pleistocene aggradation and subsequent incision (fig 6C).

Figure $6 D$ shows our preferred model of the stratigraphic architecture of the Chemehuevi Formation, which accounts for many of the common features of the formation, including the common erosional surfaces of sand over mud covering a range of elevation, as observed by Metzger and others (1973); the interbedding of sand and mud as seen near the type section; and the rhythmic successions described by Longwell (1936). In this model, the river deposited sand in channels, point bars, and proximal parts of the flood plain, while silt and clay settled from washload in quiet water on the distal parts of the flood plain or in naturally dammed tributaries. As channel bed aggradation outpaced vertical flood plain deposition, sand deposited in migrating channels would have cut into and deposited over flood plain muds, accounting for the common sand-over-mud erosional surfaces at a range of elevations within the formation (fig. 7). The sand-over-mud unconformity may, in places, reflect a local transition from a meandering channel, confined within cohesive banks, to a braided, sandchannel system that formed as the channel bed overtopped what was formerly the flood plain surface.

This model of the stratigraphic architecture (fig. 6D) implies that sand formed the bulk of the formation before its erosion, in contrast to the Metzger and others (1973) model 
that implies a mud-dominated aggradation (fig. 6B). This is in agreement with the available evidence, in particular the relative thicknesses of the sand versus the mud facies in the six thickest measured sections of the formation (fig. 8). The inference that the bulk of the formation consisted of sand, not mud, has important implications for interpreting the source area and origin of the formation.

\section{Origin of the Chemehuevi Formation}

Geologists have speculated about the cause of the aggradational episode that led to the deposition of the Chemehuevi Formation for more than 150 years. Here we evaluate the different hypotheses for its origin, and we explain our favored interpretation of the formation in the context of the data and observations presented above.

In Cottonwood Valley, Newberry (in Ives, 1861, p. 33 of the "Geological Report") noted that multiple deposits of Colorado River sediment were separated by a large amount of geologic time, "the time occupied by the Colorado in deepening its bed two hundred feet." Newberry interpreted the great thickness of the Chemehuevi Formation at Elephant Hill (fig. 3), just below the mouth of Black Canyon, as having accumulated at the base of a giant waterfall that formed as the river incised through the Black Mountains, and that "the... inevitable effect of such a cascade would be to excavate a deep basin or channel at its foot; and subsequently, as the fall was diminished, to fill that excavation with boulders of gravel and sand" (p. 39). Newberry's explanation can be eliminated for multiple reasons, including the knowledge that the Chemehuevi Formation is millions of years younger than Black Canyon, and that the deposits are traceable from the mouth of Grand Canyon to well into the river delta below Yuma.

Lee (1908) considered the "Chemehuevis gravel" to be a single depositional unit that included gravels now known to be of Tertiary age on top of Temple Bar, in the Lake Mead area, as well as sediments now included in the Chemehuevi Formation. He interpreted that "the gravels are about 700 feet in maximum thickness" (p. 18), twice as thick as the formation is now considered to be. Lee interpreted that all these sediments were deposited in a single major river aggradation, due to "some influence not certainly known" (p. 65), immediately following the cutting of the major canyons along the Colorado River below the Grand Canyon. Lee's interpretation was that rivers throughout the southwest filled their valleys with sand and gravel during this valley filling interval. However, more recent work has shown that his "Chemehuevis gravel" includes multiple Tertiary and Quaternary stratigraphic units.

Longwell's (1936) examination of the Chemehuevi Formation in the Lake Mead area led him to propose two possible explanations of their origin: "that the Colorado River was ponded by a natural dam, perhaps formed by lava, or that some change, probably climatic, caused an overloaded condition of the stream for a considerable time" (p. 1450).
His ponding explanation attributed the underlying gravel unit, which he recognized at Sandy Point (fig. 6A), to aggradation following impoundment of the Colorado River by a natural dam, such as a lava flow. He interpreted the middle, layered mud facies as distal lake deposits, and the upper, rhythmically layered, sand-rich interval to a prograding delta that built downstream over the distal mud. Although he described several lines of evidence contrary to the ponding hypothesis, Longwell subsequently favored this explanation in his later work, because the beds "appear to be definitely lacustrine" (Longwell, 1946, p. 827). Longwell (1963) also observed that the grain size, texture, and bed thicknesses of some of his Chemehuevi Formation in the area between Lake Mead and Davis Dam resemble modern deposits in the present delta of Lake Mead, supporting his conclusion that the beds were deposited in a single large lake. Multiple lines of evidence contradict this idea: (1) the absence of large-scale foreset beds in the sand unit, that would suggest a prograding delta; (2) the lack of evidence of a dam that could have created such a lake; (3) the observation that correlative deposits extend all the way to the Gulf of California; (4) the widespread presence of fluvial sedimentary features, as well as vertebrate and microfossil evidence consistent with fluvial deposition; and (5) the steep downstream gradient of the top of the Chemehuevi Formation, as compared with the modern valley (fig. 7).

Most studies of Colorado River stratigraphy (Lee, 1908; Metzger and others, 1973; Lee and Bell, 1975; Blair, 1996; House and others, 2005b; Lundstrom and others, 2008) have concluded that the sediments included here in the Chemehuevi Formation have a primarily fluvial origin. Many have commented on the conspicuous sand over mud stratigraphy common in outcrops, and regarded this characteristic as an important clue to its origin. Lee (1908, p. 43) interpreted the two units as conformable and attributed the difference as "probably due to some change in the river, such as an increase in its carrying power, enabling it to bear the finer material away and deposit only the coarser material; or to a change in course, bringing the gravel-bearing current over what had formerly been a flood plain." As noted, Metzger and others (1973) stated that the mud facies of the formation was deposited during aggradation of the river and that the sand facies was deposited during the subsequent incision following aggradation. Blair (1996) suggested that the transition from mud to sand implied a major change in depositional conditions. Specific explanations about the ultimate cause of the aggradation have eluded previous authors, although Lundstrom and others (2008) listed a number of possible driving mechanisms, including climate change, fire, glaciation, paleofloods, groundwater discharge, and natural dams upstream.

Aggradation of rivers may be caused by an imbalance between the upstream supply of bedload sediment (gravel and sand) and the transport capacity of the river, or baselevel rise, such as caused by local damming or eustatic sea-level rise. The longitudinal profile of the Chemehuevi 
Formation, which shows that it thickens in the upstream direction (fig. 7), favors an upstream forcing mechanism, rather than a downstream change in base level. Although a decrease in river-flow volume (and therefore decreased transport capacity) could also cause aggradation, the large amount of sediment stored at the peak of aggradation suggests that the primary cause was an increase in the sediment supply from upstream.

The sedimentology and stratigraphy of the formation lead us to conclude that the aggradation was caused by an oversupply of sand-size sediment rich in rounded quartz grains (fig. 11B). The Chemehuevi Formation overlies gravel-rich deposits, but the bulk of the unit itself is dominated by sand (fig. 8). We interpret the typical sand-overmud stratigraphy (fig. 1) as showing an aggrading channel bed overtopping the flood plain surface, which suggests that the channel was aggrading faster than the flood plain, due to deposition of medium and coarse sand. As aggradation proceeded, a braided sand channel system may have occupied more space in the valley floor. Braided channel patterns are common in rivers with an oversupply of bed load (for example, Schumm and Khan, 1972).

The Colorado Plateau, which is underlain by large areas of sedimentary rocks rich in rounded quartz grains, is a likely origin for much of this sand. One possibility is that much of the sediment comprising the Chemehuevi Formation was generated by climatic change over the Colorado Plateau that led to the rapid delivery of large amount of sand-sized sediment to the Colorado River in a short time. The climatic explanation is supported by the widespread presence of possibly time correlative deposits throughout the Colorado River valley. Anders and others (2005) dated gravelly Colorado River sediments in fill terraces in eastern Grand Canyon using luminescence, U-series, and cosmogenic nuclide methods. A widespread gravel at least $38 \mathrm{~m}$ thick, designated as "M3," that constituted "the most conspicuous main stem deposit in eastern Grand Canyon" (p. 2435), yielded optically stimulated luminescence ages ranging from $71 \pm 11 \mathrm{ka}$ to $64 \pm 10 \mathrm{ka}$ from 5 samples. Also, one cosmogenic radionuclide exposure date on gravels inset in the M3 unit yielded an exposure age of 55 $\pm 12 \mathrm{ka}$ (Anders and others, 2005). In addition, recent OSL ages from terraces along the Colorado River near Grand Junction, Colorado, also identified a widespread deposit dated as $\sim 65 \mathrm{ka}$. These ages from terraces along the middle and upper Colorado River suggest that the Chemehuevi Formation may be time correlative to deposits many hundreds of $\mathrm{km}$ upstream, supporting a generic climatic explanation for their origin.

Alternative explanations for the origin of the Chemehuevi Formation have not been ruled out. For example, a large increase in sediment supply might be expected following the integration of a previously internally drained tributary into the Colorado River drainage network, possibly leading to aggradation in the lower gradient reaches in the Basin and Range. The emplacement and removal of a landslide dam in Black Canyon could also explain many features of the formation. Such a dam could have created a large lake in the area now submerged by Lake Mead, partially substantiating Longwell's (1936) interpretation of a giant Pleistocene "Lake Chemehuevi." The breaching of a sediment-filled dam in Black Canyon could have led to rapid fluvial aggradation below Black Canyon and explain the primarily fluvial features seen downstream of Hoover Dam.

\section{Designation as a Lithostratigraphic Unit}

One purpose of this report is to formally name the Chemehuevi Formation as a stratigraphic unit according to the procedures of the North American Stratigraphic Code (North American Commission on Stratigraphic Nomenclature, 2005). As has been established, the Chemehuevi Formation constitutes a mappable stratigraphic unit, with distinctive facies assemblages and stratigraphic position. Previous studies of the unit have been confused by inconsistent nomenclature and usage, and regional mapping and stratigraphic studies would benefit from a more systematic and formal definition.

Article 3 of the Stratigraphic Code (North American Commission on Stratigraphic Nomenclature, 2005, p. 1561) stipulates the procedure for formal definition of geologic units, which includes:

(i) intent to designate or modify a formal unit;

(ii) designation of category and rank of unit; (iii) selection and derivation of name; (iv) specification of stratotype (where applicable); (v) description of unit; (vi) definition of boundaries; (vii) historical background; (viii) dimensions, shape, and other regional aspects; (ix) geologic age; (x) correlations; and possibly (xi) genesis (where applicable).

The preceding sections of this report fulfill requirements (i), (v), and (vi) through (xi) by a detailed discussion of new and previous data and observations of the formation. This section completes the remaining requirements by specifying the category and rank of the unit; explaining the derivation of the name; and specifying and describing a type section and additional reference sections.

\section{Category and Rank}

The Chemehuevi Formation is considered here to be a lithostratigraphic unit, or lithoformation, as described in the North American Stratigraphic Code (North American Commission on Stratigraphic Nomenclature, 2005): "a defined body of sedimentary, extrusive igneous, metasedimentary, or metavolcanic strata that is distinguished and delimited on the basis of lithic characteristics and stratigraphic position" 
(p. 1566). The formation is here proposed to be a lithoformation as opposed to an alloformation, which is defined as "a mappable body of rock that is defined and identified on the basis of its bounding discontinuities." According to the Code, "the lithology of an allostratigraphic unit plays no part in its definition" (p. 1578). Although stratigraphic position and bounding unconformities are critical to the definition of the formation, the unit is recognized in large part on the basis of distinct lithic characteristics, including chemical and mineralogical composition, texture, color, geomorphic expression, bedding characteristics, fossil assemblages, and volcanic ash. According to the code a lithostratigraphic unit "may contain between its upper and lower limits. . repetitions of two or more lithic types" (p. 1567). Many of the characteristic lithic types within the Chemehuevi Formation are described in detail above and in some places are recognized as distinctly mappable facies.

\section{Selection and Derivation of Name}

The name Chemehuevi Formation is adopted from the earlier use of Lee (1908) and Longwell (1936, 1946, 1963) and Longwell and others (1965) for a group of dominantly fine grained, nonmarine sedimentary rocks deposited along the valleys of the Colorado River and its tributaries in the Basin and Range geologic province, including minor intercalated beds of locally derived gravel and volcanic ash. We retain the name Chemehuevi from the Chemehuevi Valley (fig. $2 A$ ) now partly occupied by Lake Havasu. This honors the long-standing use of the name Chemehuevis or Chemehuevi for the most distinctive deposits as used by Lee (1908) and Longwell (1936, 1946, 1963) and Longwell and others (1965). Here we define the Chemehuevi Formation (as Longwell used the term in his later publications), adopting the generally used spelling of the Chemehuevi Valley.

Our concept of the formation retains Longwell's (1936) and Lee's (1908) essential lithologic characteristics for the formation. We exclude some occurrences that Longwell considered part of the formation - including gravels on top of Delmar Butte (230 $\mathrm{m}$ above the historic river) and cemented gravel nearly $270 \mathrm{~m}$ above the Colorado River at Sugarloaf Hill near Hoover Dam (Longwell, 1963, p. E15)—because these gravels do not share the basic lithologic characteristics of the Chemehuevi Formation and are significantly higher in elevation than other outcrops of the formation, and therefore, do not appear to be correlative.

\section{Stratotypes and Reference Sections}

\section{Type section—Loaf Rock hill}

We propose as a type section (or unit stratotype) of the Chemehuevi Formation a typical exposure at a hill called Loaf Rock near the Katherine Ranger Station, Ariz., in Lake Mead National Recreation area (in the NW quadrant of sec. 7, T. 21 N, R. 21 W; Davis Dam Quadrangle) (figs. 24 through 27). Although the proposed type area is not geographically located within Chemehuevi Valley, this is an accessible site containing multiple outcrops of the formation that exhibit many of the unit's characteristic features, including the typical stratigraphy of unconsolidated sand overlying well bedded mud on an unconformable contact at more than one elevation; interbedded lenses of locally derived gravel; a thin volcanic ash layer chemically similar to the Monkey Rock tephra bed; and examples of an interfingering relationship between the sand and the mud and of interfingered angular conglomerate.

The proposed type section underlies a hill called Loaf Rock, adjacent to a parking lot at the Katherine Ranger Station (fig. 24A). At the type locality, the Chemehuevi Formation unconformably overlies megacrystic Proterozoic granite (Faulds and others, 2004) (fig. 25). Faulds and others (2004) preliminarily mapped the material forming the type section as the fine grained and coarse grained facies of their "Chemehuevi alluvium." They mapped a nearby sand-over-mud section as the fine and coarse grained facies of their "Mohave alluvium" $\left(\mathrm{Qcm}_{\mathrm{f}}\right.$ and $\left.\mathrm{Qcm}_{\mathrm{c}}\right)$, which they interpreted as a younger package inset into the Chemehuevi alluvium (figs. $5 \mathrm{C}$ and $6 \mathrm{C}$ ). More recent (currently unpublished) revisions of this mapping considers both as the Chemehuevi Formation as defined here (fig. 24C). A simplification of a $45-\mathrm{m}$ thick measured section at proposed type locality is in table 7 , and appendix 9 contains a detailed description of the measured section.

Figure 25 depicts the type section graphically. Beds below the base of the measured section are covered by younger sediments in a recent wash; however, beds continuous with the measured section are clearly seen overlying the Proterozoic Davis Dam granite nearby at a similar elevation (fig. 25A). The lowest $21 \mathrm{~m}$ of the type section (intervals A through L in fig. 25) are typical of the mud and valley margin facies of the formation, consisting of horizontally bedded sand, mud, and intercalated locally derived gravel. Near the base of the section, typical sand and mud beds interfinger with angular gravel (intervals A, B, and D); the overlying 15 meters (intervals E through L) consist of horizontally bedded sand and mud with a characteristic bedding thickness of one to several decimeters, and include a bed 1-5 mm thick of white tephra (fig. 19B) discussed above.

An erosional surface marks the top of the mud facies in the type section at an elevation of approximately 223 meters above sea level (fig. 26). This surface is overlain by $28 \mathrm{~m}$ of poorly exposed, wind-reworked sediment belonging to the sand facies. The sand facies in the type section includes an interval of angular gravel about $1.5 \mathrm{~m}$ thick near the base (interval N; fig. 25); other lenses appear higher in the section. In contrast to the bluff-forming underlying mud facies, the poorly exposed, wind-reworked sand facies forms slopes that vary from zero at the top surface to 30 degrees at the thick gravel interval. 
The slope-forming sand facies and the bluff-forming mud facies can be traced $0.3 \mathrm{~km}$ to the northwest where they interfinger over an interval 4 to $6 \mathrm{~m}$ thick (fig. 27). The observation that the sand facies and mud facies interfinger has not been reported before and invalidates the concept of Metzger and others (1973) that the mud facies (which they called unit D) was deposited during a period of aggradation and the sand (unit E) was deposited during temporary halts in the subsequent downcutting episode (fig. 6B).

\section{Reference Section-Katherine Landing near Loaf Rock}

A 19.5 -m thick section of the formation about $0.5 \mathrm{~km}$ southwest of the type section, adjacent to Lake Mohave (fig. $24 A$ ), is here described as a reference section for the Chemehuevi Formation. Appendix 10 is a detailed log of the section. The outcrop is partially submerged beneath Lake Mohave, but exposes a greater thickness of the sand facies than is visible in the type section. This reference section is not contiguous with the type section (fig. 24B), and is at partly overlapping but generally lower elevations (the vertical bar in fig. 28 shows the relative elevation range of the type section). The contact of the sand facies over the mud facies is $19 \mathrm{~m}$ lower in elevation in the reference section compared with the type section. The lowest $7 \mathrm{~m}$ of the reference section are the mud facies, consisting of horizontally bedded sand and mud with ripple crossbedding and load casts in the fine sand beds (as shown in fig. 10C). The mud facies here is overlain on an erosional surface by a lens $0.3 \mathrm{~m}$ thick of locally derived, angular gravel (interval D, fig. 28) and $13 \mathrm{~m}$ of poorly consolidated, quartz-rich medium sand typical of the sand facies (intervals $\mathrm{F}$ through $\mathrm{H}$ ). The relatively well-exposed sand facies contains crossbedded sand, pebbles, mud balls, and abundant carbonate-cemented root mats and vertical root and stem casts that cross bed boundaries. The top of the exposed section is on a sharp ridge of unconsolidated sand, which can be traced to wider surfaces on top of which is a wind lag of pebble gravel containing mostly locally derived clasts.

Faulds and others (2004) mapped this reference section as their "Mohave alluvium" (fig. 24C), which they inferred to be a younger unit inset into the nearby type section. More recent revision of this map includes this deposit within the Chemehuevi Formation. In this report we interpret that the two stratigraphic sections belong to the same aggradational package and both belong to the Chemehuevi Formation.

\section{Reference Section-Old Callville Outcrop Described by Longwell (1936)}

The thickest continuous section of the formation is the now-submerged remnant near the site of Old Callville (fig. 4), described by Longwell, "where practically every layer is exposed through a thickness of nearly 400 feet" (Longwell,
1936, p. 1444). Because it includes features not seen in the type locality, we include Longwell's description of the Callville section (fig. 28; appendix 4) as another reference section for the Chemehuevi Formation.

As described by Longwell (1936), the Callville remnant is composed of three principal members: (1) a lower one of approximately $38 \mathrm{~m}$ of coarse, crossbedded sand with scattered layers of silt and clay; (2) a middle member about $18 \mathrm{~m}$ thick consisting of well-bedded clay, silt, and fine sand; and (3) an upper member about $84 \mathrm{~m}$ thick of coarse, crossbedded sand divided by several layers of clay (fig. 27).

Longwell (1936) subdivided the upper member into 19 discrete "varve-like" units, characterized by thin silt and clay layers alternating with thick intervals of crossbedded sand. Longwell's bison horn (Longwell, 1936, p. 1453) was found in the upper sandy member near Callville. The thickest sand interval in the upper member was described as $28 \mathrm{~m}$ of "coarse cross-bedded sand, without break" (p. 1446). We consider the upper member at Callville to be the rhythmite facies as discussed above.

In contrast to the sand-dominated rhythmite upper member, Longwell (1936) described the $18 \mathrm{~m}$-thick middle member of the Callville remnant as being devoid of coarse-grained sediment. The middle member of the Callville section is characterized by regular thin beds (some of which are laminated), by a high proportion of pure clay, and by a lack of erosional unconformities. Longwell (1936) measured a detailed section of the middle member, consisting of thirty individual layers; of the 18-m thick subunit, 53 percent of the section was described as clay (appendix 4). Longwell traced the middle member of the Callville reference section to a section that contains a thick lens of dominantly locally derived gravel with inclined bedding; this gravel is pictured in Longwell 's (1936) report (plate 15, figure 1), and appears to be an isolated remnant of a fan derived from the Black Mountains that is interfingered in the middle member. The middle member in the Callville reference section appears similar to the mud facies of the Chemehuevi Formation, which is common downstream of Hoover Dam.

The lowest member of the Callville section consists of a poorly exposed interval of cross-bedded coarse sand with scattered layers of clay and silt and nearby includes a thick (more than $3 \mathrm{~m}$ ) gray volcanic ash bed near the top (fig. 29). Although exposures were too limited to allow a detailed description of the lower subunit, Longwell (1936, p. 1447) inferred that it was similar to the bedding in the upper member, "but with the addition of perceptible calcium carbonate as cement. " As noted, the atypical cementation described for the lower member leaves us uncertain whether it might underlie the formation as we conceive of it.

\section{Conclusions}

The Chemehuevi Formation consists of nonmarine sediment along lower Colorado River valley and major tributaries 

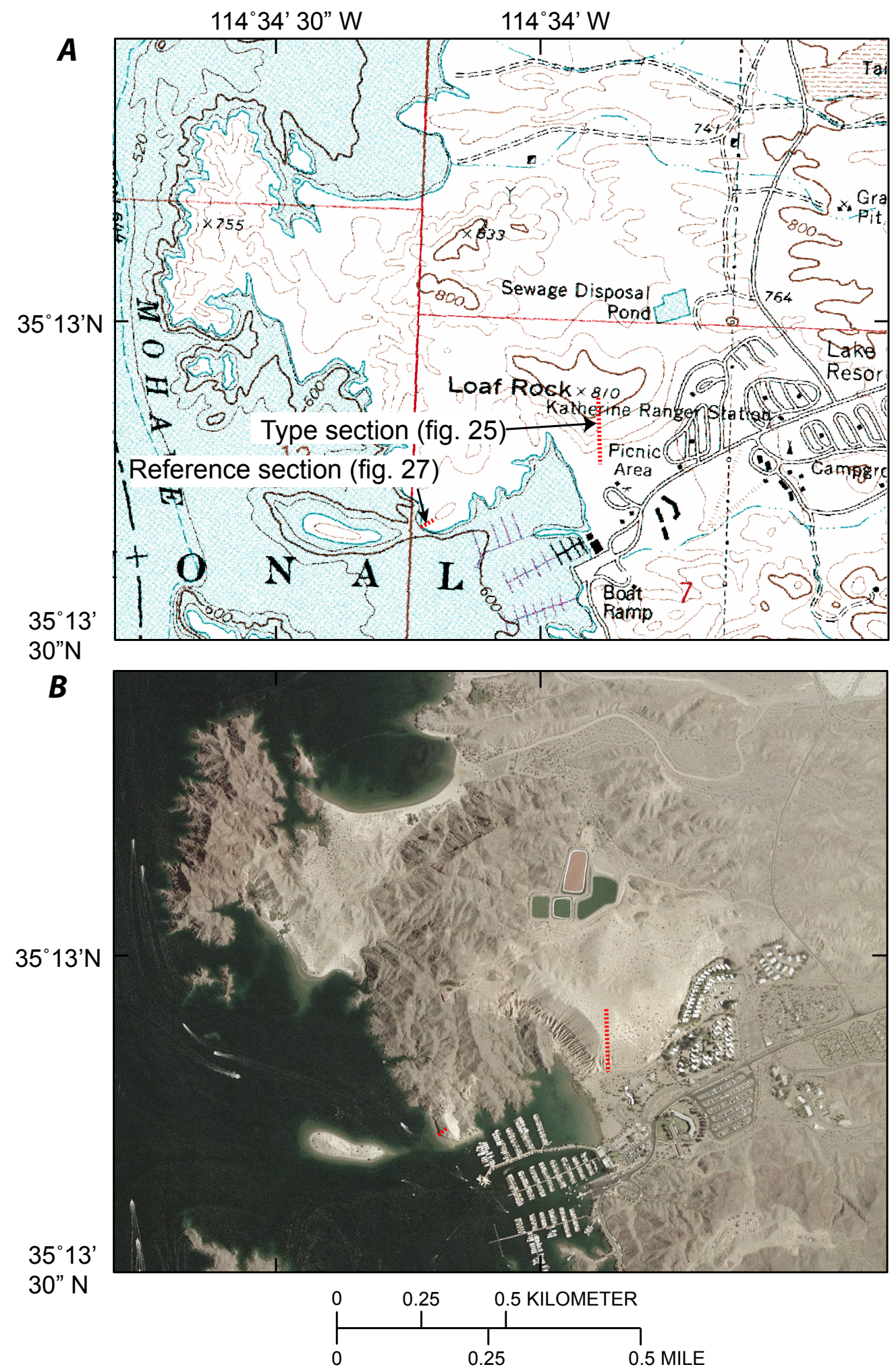

Figure 23. Location map of proposed type area at Katherine Landing, in Lake Mead National Recreation Area, Ariz. Red dotted lines indicate locations of measured type section and reference section. $A$, Part of the U.S. Geological Survey Davis Dam 7.5-minute quadrangle. B, Digital orthophotograph of type locality taken in 2004. C, Part of the preliminary geologic map of the Davis Dam quadrangle, including unpublished mapping from P.K. House. Abbreviations of geologic units: Ydg, Proterozoic megacrystic granite; Tf and Tfb, pre-Colorado River fanglomerate; Qai, intermediate-age alluvial fan deposits; Qchm, mud facies of Chemehuevi Formation; Qchs, sand facies of Chemehuevi Formation. 


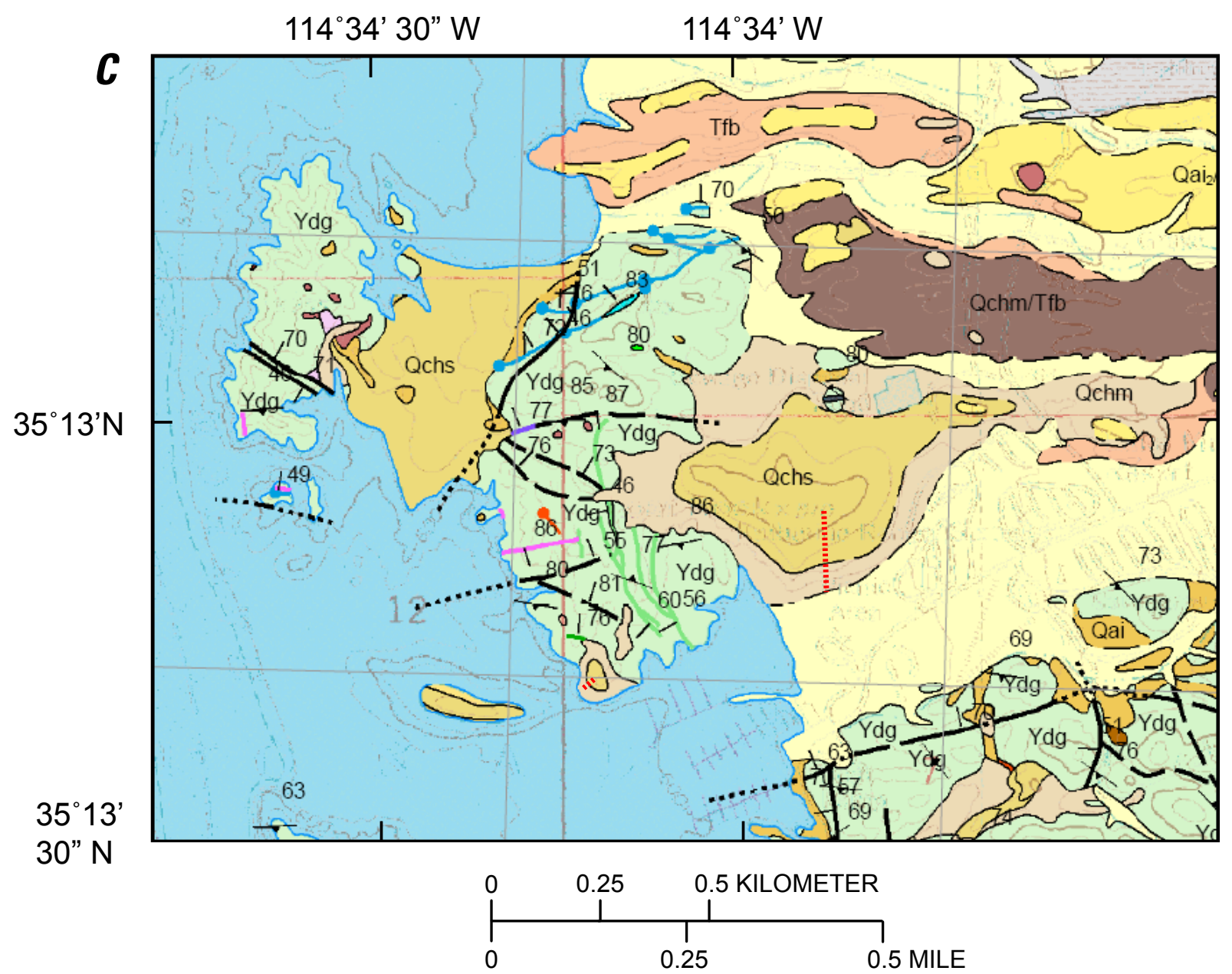

Figure 23. Continued

in the Basin and Range geologic province and is here proposed as a formal lithostratigraphic unit, consisting of the remnants of the most recent major geologic aggradation of the Colorado River below the Grand Canyon. Geologic mapping shows the unit is regionally mappable and is interpreted as being bounded below and above by laterally traceable discontinuities. Remnants of the formation are widespread and conspicuous throughout the valley of the river and its major tributaries, and have informally been associated with the name Chemehuevi or Chemehuevis, after Chemehuevi Valley.

The two most common lithologic types are a horizontally bedded mud facies dominated by fine sand, silt, and clay, and a poorly exposed, poorly-bedded facies dominated by medium sand including rounded quartz grains, scattered angular to rounded gravel, and widespread crossbedding. The sedimentology and paleontology of these two facies suggest that they were deposited in flood plain and channel environments, respectively, along a rapidly aggrading Colorado River. Other lithofacies include a thick bedded rhythmite facies described by Longwell (1936) before most of it was drowned by Lake
Mead; deposits of major tributary valleys; and poorly sorted, poorly bedded sediments mixed with sediment from local washes and deposited near the valley margins. Regionally, the sequence includes rare tephra layers and an underlying basal member at least $15 \mathrm{~m}$ thick. An "envelope" containing the surveyed outcrops of the formation delineates a smooth line that slopes 50 percent more steeply than the modern valley floor over a valley distance of more than $700 \mathrm{~km}$, and a line connecting the tephra layers is twice as steep as the modern valley. This steepened longitudinal profile is likely to represent a depositional slope.

In at least four localities, layers of fine-grained, unconsolidated volcanic tephra have been found below or within the mud facies of the Chemehuevi Formation. On the basis of chemical and stratigraphic evidence, a likely source area for the tephra is the Mammoth Mountain dome complex in the Long Valley region of California. The Mammoth Mountain complex was active between $111 \pm 2 \mathrm{ka}$ and $57 \pm 2 \mathrm{ka}$ and was most active during the last 10,000 years of this interval (Hildreth, 2004). The stratigraphic context of chemically similar 
A

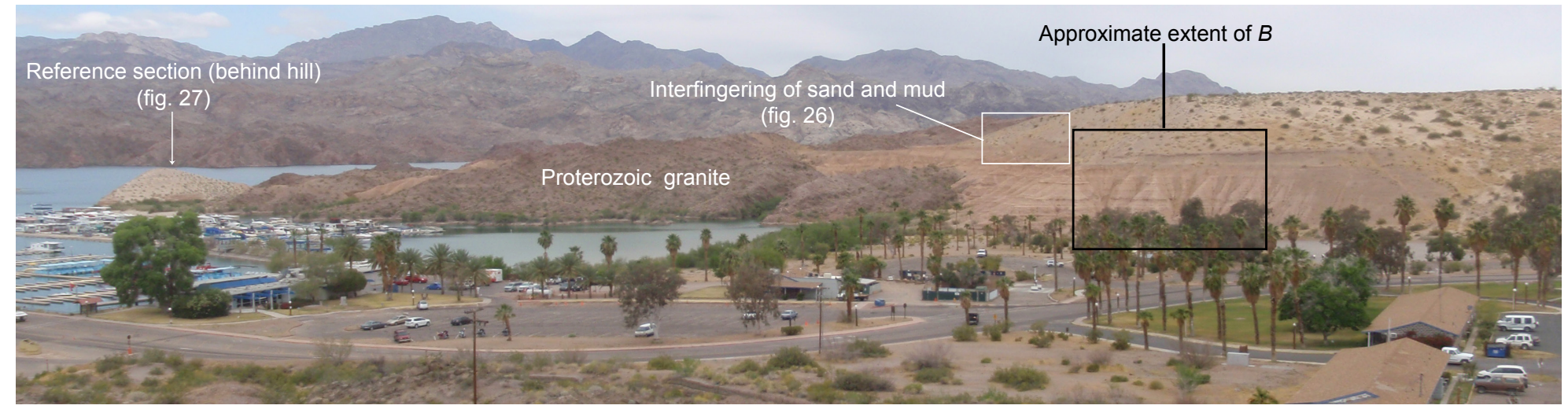

B

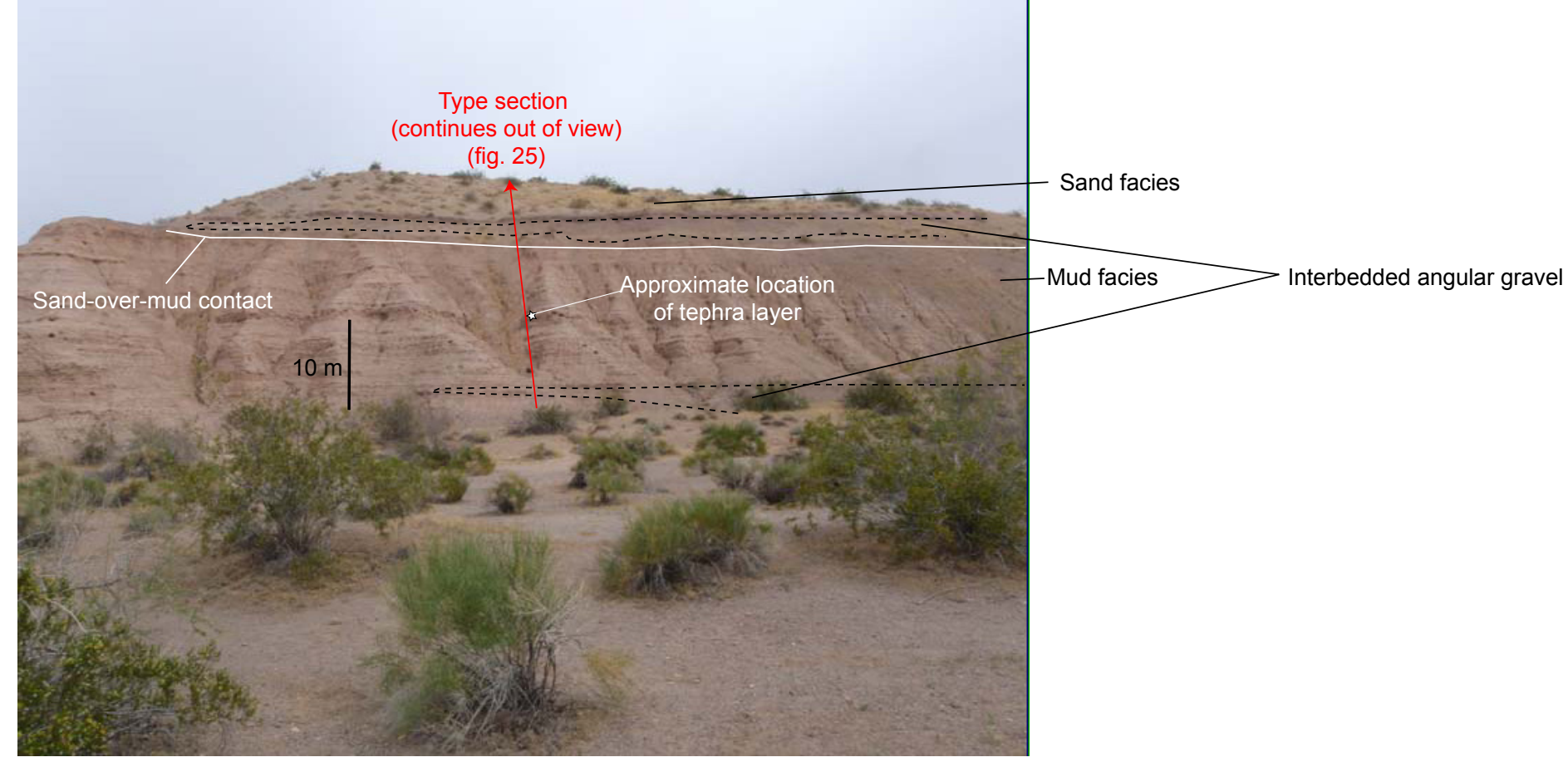

Figure 24. Photographs of type locality and type section of the Chemehuevi Formation near Katherine Landing, Ariz. A, Panoramic view of type locality, showing the location of the type section and reference section. B, Close up of type section at Loaf Rock hill. 


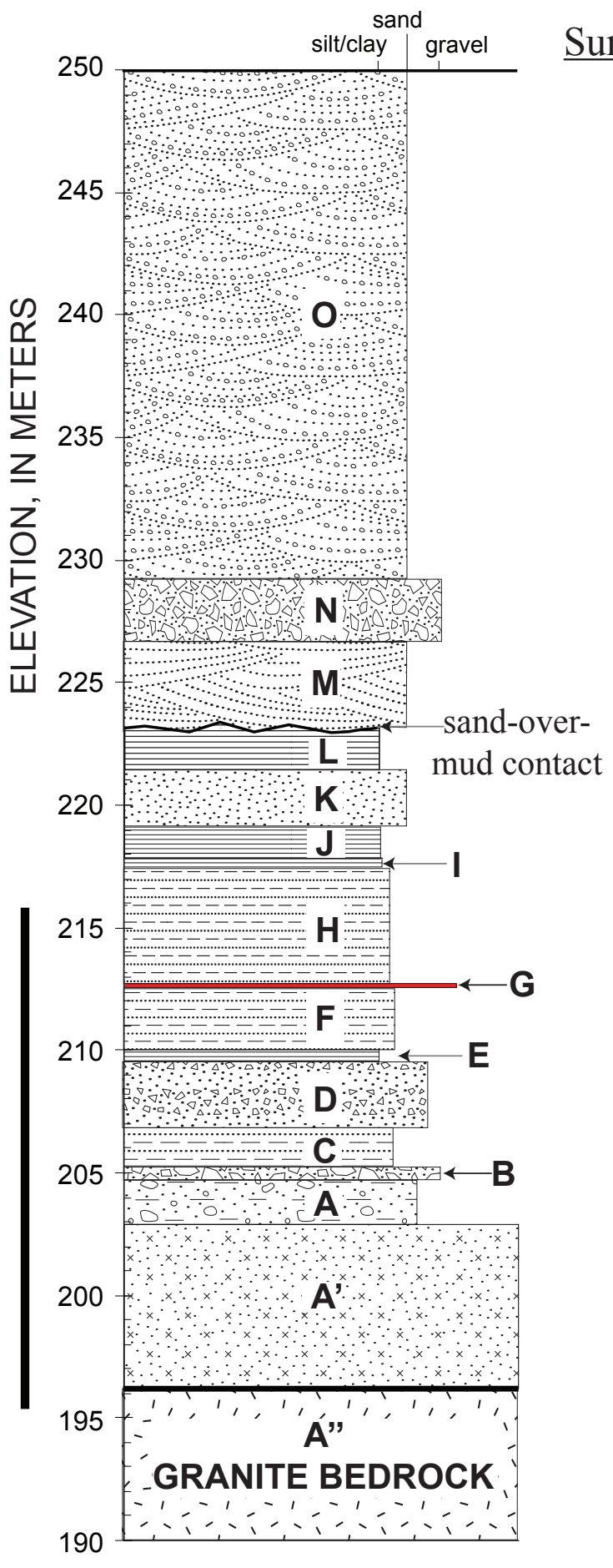

O. Poorly exposed medium sand; wind reworked with discontinuous gravel lag on surface; locally high concentrations of gravel float $(31.7 \mathrm{~m})$.

Sand

N. Lens of locally derived gravel $(1.5 \mathrm{~m})$.

M. Poorly exposed medium sand $(3.7 \mathrm{~m})$.

L. Clay-rich bedded mud; top $2 \mathrm{~mm}$ is cemented locally with carbonate; upper contact may be erosional $(1.4 \mathrm{~m})$.

$\mathrm{K}$. Massive sand bed; fines upwards from coarse sand at base to fine sand at top, grading into a $5-10 \mathrm{~cm}$ thick mud cap (2.2 m).

J. Mud-dominated beds with decimeterscale bedding, some white carbonate concretions $(1.4 \mathrm{~m})$.

I. Single bed of massive silt; fluffy, poorly consolidated, non resistant $(0.6 \mathrm{~m})$.

H. Bedded fine sand, silt, and clay; red-brown; gypsum; root stains $(4.35 \mathrm{~m})$.

G. White tephra $(0.005 \mathrm{~m})$.

F. Fining upwards sand, silt and clay beds, dominated by fine and very fine sand $(2.83 \mathrm{~m})$.

E. Silt- and clay-dominated beds $(0.5 \mathrm{~m})$.

D. Sand and gravel beds with a large component of side-stream material $(2.7 \mathrm{~m})$.

C. Sand, silt and clay beds $(1.6 \mathrm{~m})$.

B. Thick bed of angular cobble gravel (0.3 m).

A. Fine sand and mud beds interfingering with angular pebble and cobble gravel $(2.1 \mathrm{~m})$.

A'. Covered interval below type section; nearby consists mostly of angular gravel.

A" Proterozoic megacrystic granite substrate (exposed $200 \mathrm{~m}$ to the west).

Figure 25. Generalized column of the type section of the Chemehuevi Formation near Katherine Ranger Station, Arizona. Table 9 contains a detailed description of the measured section. Section is in the northwest quadrant of sec. 7, T. 21 N, R. 21 W. (outcrop feature is labeled "Loaf Rock" on Davis Dam quadrangle; see fig. 23 for location). Descriptions on the right were generalized by lumping similar beds into the divisions shown above. Vertical bar to the left of section indicates the elevation range of reference section about $0.5 \mathrm{~km}$ to the west (fig. 27). 


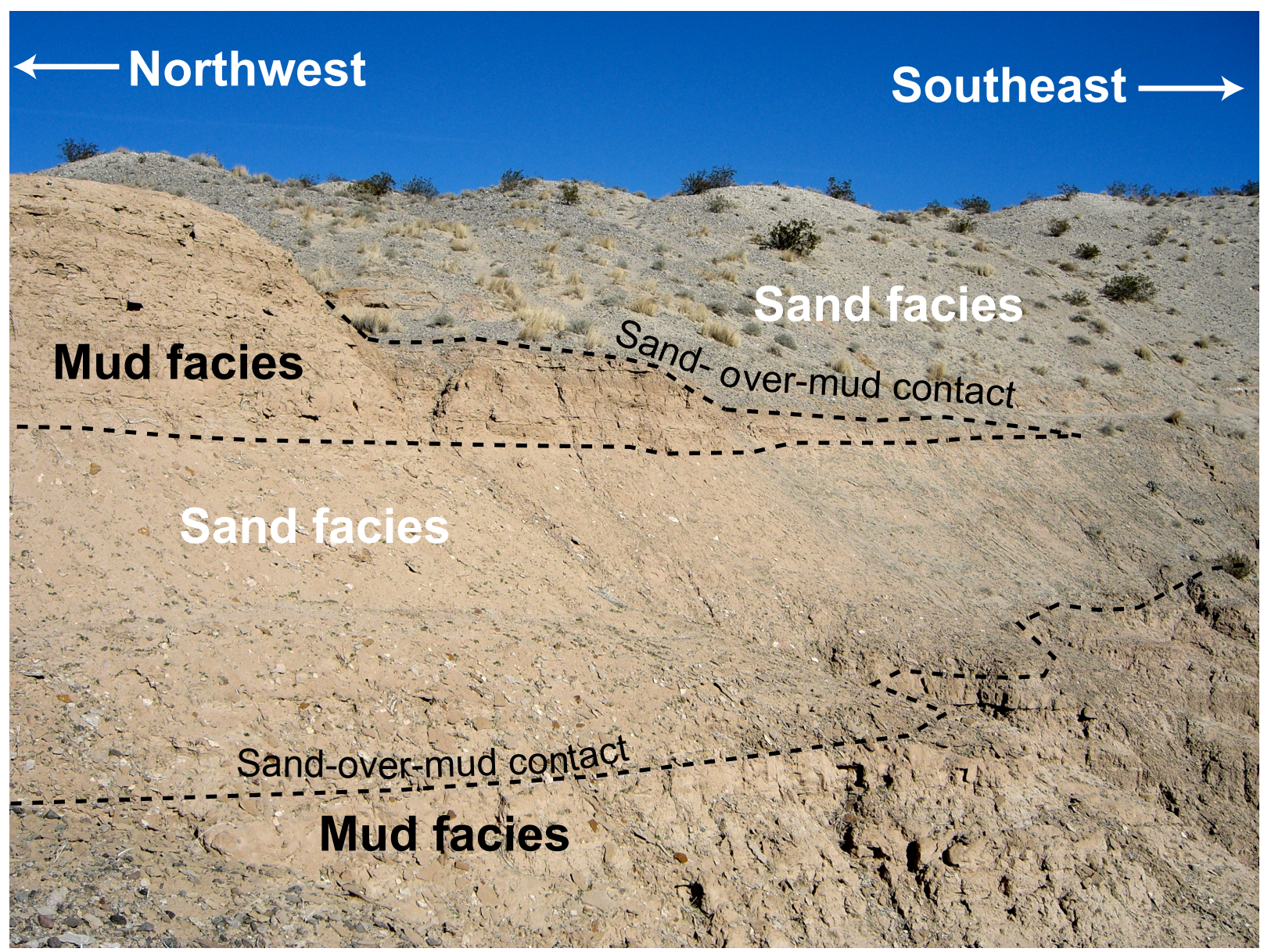

Figure 26. Interfingering relationship between the slope-forming sand facies and the cliff-forming mud facies in an exposure contiguous with and $200 \mathrm{~m}$ west of the type section of the Chemehuevi Formation on the southwest side of Loaf Rock hill near Katherine Landing. Sand fingers out to the northwest and mud fingers out to the southeast. The net result is that the mappable sand over mud contact climbs stratigraphically and topographically to the northwest (left), as implied in figures $5 D$ and $6 D$. The two facies are interfingered through a thickness of $5 \mathrm{~m}$. 


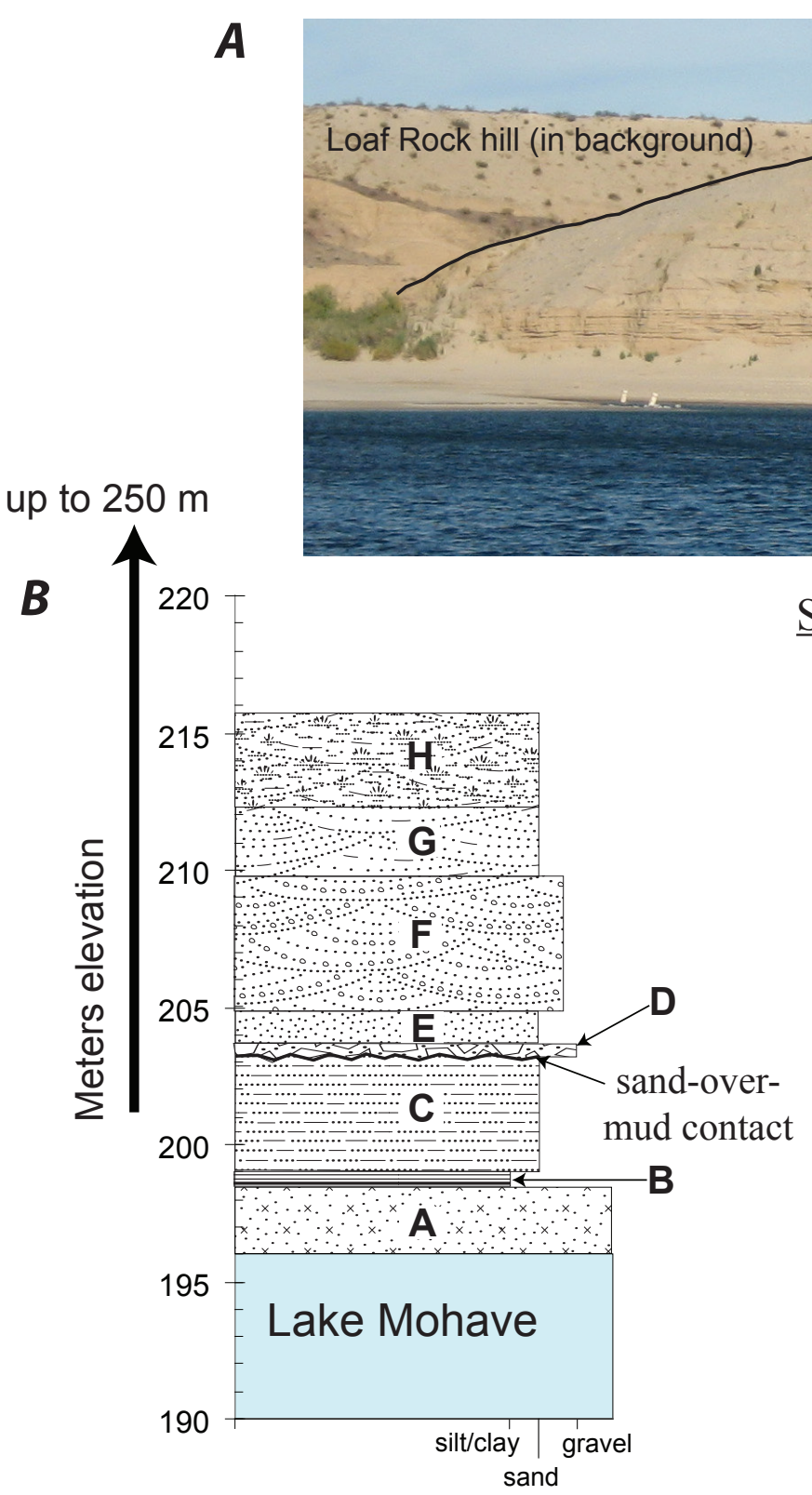

\section{Summary Descriptions:}

H. Poorly consolidated, poorly exposed medium sand with abundant carbonate-cemented root and stem zones crossing bedding planes $(3.0 \mathrm{~m})$.

G. Poorly consolidated, poorly exposed medium sand with tabular cross beds, and low-angle concave-up cross bedding; rusty zones $(2.1 \mathrm{~m})$.

F. Pebbly sand with horizontal lamination, tabular cross beds, and low-angle concave-up cross bedding; sets up to $1 \mathrm{~m}$ thick; lightly carbonate-cemented sand in upper $25 \mathrm{~cm}$ of interval $(5.6 \mathrm{~m})$.

\lceil
E. Massive coarse sand. Sorting increases upward from pebbly sand to sand; horizontal lamina- tions; grains rounded and angular; base is gradational $(0.9 \mathrm{~m})$.
D. Angular gravel of locally derived clasts (sidestream deposit);
Sand pebbles to granules; poorly sorted;
C. Beds of 2-35-cm thick, upwards fining, sand-dominated layers with mud caps; common ripple-scale cross bedding and root stains. Upper contact is erosional $(4.5 \mathrm{~m})$.
B. Gypsiferous mud beds with horizontal laminae $(0.3 \mathrm{~m})$.
A. Covered interval of mud and sand $(2.0 \mathrm{~m})$.

facies sharp base $(0.3 \mathrm{~m})$.

Figure 27. Photograph $(A)$ and abbreviated reference section $(B)$ of the Chemehuevi Formation near Katherine Landing, Ariz. Section is in the northwest quadrant of sec. 7, T. $21 \mathrm{~N}$, R. 21 W. (see fig. 23). This section is abbreviated by lumping similar beds into the divisions shown above; appendix 9 contains a more detailed description of the measured section. Vertical bar with arrow, to the left of graphical section, indicates the elevation range covered in the type section (fig. 25 ), measured about $0.5 \mathrm{~km}$ to the east. 
Table 7. Detailed type section of the Chemehuevi Formation next to the Katherine Ranger Station, Ariz.

[Measured by D. Malmon and K. Howard]

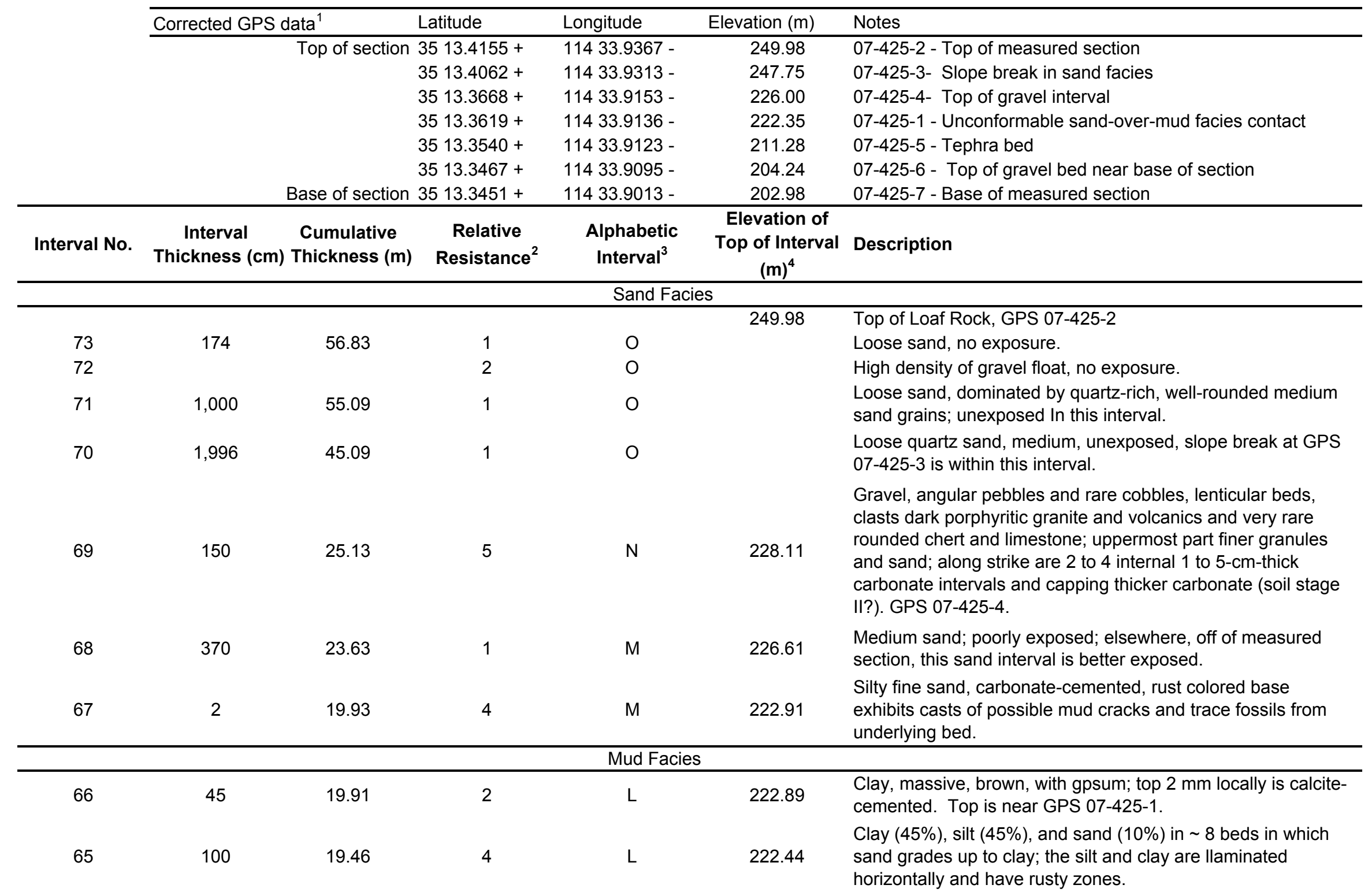


Table 7. Detailed type section of the Chemehuevi Formation next to the Katherine Ranger Station, Ariz.-Continued [Measured by D. Malmon and K. Howard]

\begin{tabular}{|c|c|c|c|c|c|c|}
\hline Interval No. & $\begin{array}{l}\text { Interval } \\
\text { Thickness (cm) }\end{array}$ & $\begin{array}{l}\text { Cumulative } \\
\text { Thickness (m) }\end{array}$ & $\begin{array}{c}\text { Relative } \\
\text { Resistance }^{2}\end{array}$ & $\begin{array}{l}\text { Alphabetic } \\
\text { Interval }^{3}\end{array}$ & $\begin{array}{l}\text { Elevation of } \\
\text { Top of Interval } \\
(\mathrm{m})^{4}\end{array}$ & Description \\
\hline 64 & 225 & 18.46 & 6 & $\mathrm{~K}$ & 221.44 & $\begin{array}{l}\text { Sand, massive, grades upward from medium to coarse } \\
( \pm \text { angular granules) at base to fine sand in top } 60 \mathrm{~cm} ; 5 \text { to } 10 \\
\mathrm{cm} \text { silty fine sand at top; mudball } 6 \times 15 \mathrm{~cm} \text { at } 45 \mathrm{~cm} \text { above } \\
\text { base. }\end{array}$ \\
\hline 63 & 32 & 16.21 & 3 & $\mathrm{~J}$ & 219.19 & $\begin{array}{l}\text { Clay, brown, with gypsum crystals; conchoidal fractures in two } \\
\text { beds that fine upward from thin silty fine sand or silt layers; } \\
\text { base is the mud cap of underlying bed. }\end{array}$ \\
\hline 62 & 18 & 15.89 & 4 & $\mathrm{~J}$ & 218.87 & $\begin{array}{l}\text { Silty very fine sand, grades upward into the (overlying) clay } \\
\text { bed. }\end{array}$ \\
\hline 61 & 95 & 15.71 & 3 & $\mathrm{~J}$ & 218.69 & $\begin{array}{l}\text { Mud including laminated clay, some sand beds; beds } 10 \text { to } 30 \\
\mathrm{~cm} \text { thick; some white carbonate concretions in the brown clay } \\
\text { and around rust colored spots. }\end{array}$ \\
\hline 60 & 60 & 14.76 & 2 & 1 & 217.74 & Silt, massive, fluffy, poorly consolidated, nonresistant. \\
\hline 59 & 25 & 14.16 & 5 & $\mathrm{H}$ & 217.14 & $\begin{array}{l}\text { Silty fine sand to fine sand; massive; partly rust colored in } \\
\text { broad blobby zones rare horizontal plant stem stains; } \\
\text { nonresistant. }\end{array}$ \\
\hline 58 & 35 & 13.91 & 3 & $\mathrm{H}$ & 216.89 & $\begin{array}{l}\text { Clay-rich mud; probably fines upward from silt to clay; a few } \\
\text { vertical root stains. }\end{array}$ \\
\hline 57 & 28 & 13.56 & 4 & $\mathrm{H}$ & 216.54 & $\begin{array}{l}\text { Silty fine sand with } 2 \text { mud intervals } 1 \text { to } 5 \mathrm{~cm} \text { in variable } \\
\text { thickness; base has } 5 \text { to } 10 \mathrm{~cm} \text { relief; resistant. }\end{array}$ \\
\hline 56 & 52 & 13.28 & 3 & $\mathrm{H}$ & 216.26 & $\begin{array}{l}\text { Clay and silt ( } 80 \%) \text {, poorly bedded; } 3 \text { or more sand layers; } \\
\text { aquitard with local rust colored zone at top. }\end{array}$ \\
\hline 55 & 15 & 12.76 & 3 & $\mathrm{H}$ & 215.74 & $\begin{array}{l}\text { Fine sand }(90 \%) \text { in } 2 \text { beds that fine upward to } 1 \mathrm{~cm} \text { clay caps; } \\
\text { an orange stain between the } 2 \text { beds. }\end{array}$ \\
\hline 54 & 12 & 12.61 & 3 & $\mathrm{H}$ & 215.59 & Massive silty clay, \pm laminated, \pm gypsum present. \\
\hline 53 & 15 & 12.49 & 5 & $\mathrm{H}$ & 215.47 & Sand, thin-bedded, and laminated mud; resistant. \\
\hline 52 & 63 & 12.34 & 4 & $\mathrm{H}$ & 215.32 & $\begin{array}{l}\text { Mud (clayey silt to silty clay), blocky; includes well sorted clay } \\
\text { beds with gypsum crystals; clay laminated to massive; one or } \\
\text { more } 5 \mathrm{~cm} \text { bed of silty very fine sand. }\end{array}$ \\
\hline 51 & 15 & 11.71 & 5 & $\mathrm{H}$ & 214.69 & $\begin{array}{l}\text { Fine to very fine sand, massive, fines upward, well sorted, } \\
\text { rounded; } 1 \mathrm{~cm} \text { rust colored zone at top; resistant. }\end{array}$ \\
\hline 50 & 25 & 11.56 & 3 & $\mathrm{H}$ & 214.54 & $\begin{array}{l}\text { Fine sand fining upward in one bed to pure clay } 2 \text { to } 10 \mathrm{~cm} \\
\text { thick includintg } 1 \mathrm{~cm} \text { bed of fine sa.nd; flat top; base has } 8 \text { to } \\
11 \mathrm{~mm} \text { relief. }\end{array}$ \\
\hline
\end{tabular}




\begin{tabular}{|c|c|c|c|c|c|c|}
\hline Interval No. & $\begin{array}{l}\text { Interval } \\
\text { Thickness }(\mathrm{cm})\end{array}$ & $\begin{array}{l}\text { Cumulative } \\
\text { Thickness (m) }\end{array}$ & $\begin{array}{c}\text { Relative } \\
\text { Resistance }^{2}\end{array}$ & $\begin{array}{l}\text { Alphabetic } \\
\text { Interval }^{3}\end{array}$ & $\begin{array}{l}\text { Elevation of } \\
\text { Top of Interval } \\
(\mathrm{m})^{4}\end{array}$ & Description \\
\hline 49 & 35 & 11.31 & 3 & $\mathrm{H}$ & 214.29 & $\begin{array}{l}\text { Silty clay. Bedded, brown to red; vertical root stains; } 10 \\
\text { percent of thickness composed of about } 3 \text { intervals of fine } \\
\text { sand. }\end{array}$ \\
\hline 48 & 15 & 10.96 & 3.5 & $\mathrm{H}$ & 213.94 & Medium to coarse sand, fining upward, lithic rich. \\
\hline 47 & 8 & 10.81 & 4 & $\mathrm{H}$ & 213.79 & $\begin{array}{l}\text { Sand }(50 \%) \text { and overlying mud in } 4 \text { couplets, each about } 2 \mathrm{~cm} \\
\text { thick. }\end{array}$ \\
\hline 46 & 11 & 10.73 & 4 & $\mathrm{H}$ & 213.71 & $\begin{array}{l}\text { Silty fine sand, capped by } 1 \mathrm{~cm} \text { silty clay which exhibits } \\
\text { vertical root stains. }\end{array}$ \\
\hline 45 & 3 & 10.62 & 4 & $\mathrm{H}$ & 213.60 & Clay. \\
\hline 44 & 15 & 10.59 & 4 & $\mathrm{H}$ & 213.57 & $\begin{array}{l}\text { Medium-coarse sand, fining upward, well sorted, lithic rich; } \\
\text { vertical root stains. }\end{array}$ \\
\hline 43 & 63 & 10.44 & 4 & $\mathrm{H}$ & 213.42 & $\begin{array}{l}\text { Fine sand }(50 \%) \text { and silty clay ( } 50 \% \text {, red-brown, blocky) in } \\
\text { bedded interval with } 7 \text { clay beds, each in a couplet ( } 3 \text { to } 10 \\
\mathrm{~cm} \text { ) over fine sand; vertical root stains. }\end{array}$ \\
\hline 42 & 0.2 & 9.81 & 5 & G & 212.79 & White tephra. GPS 07-424-6. \\
\hline 41 & 40 & 9.81 & 4 & $\mathrm{~F}$ & 212.79 & $\begin{array}{l}\text { Fine sand (lower } 28 \mathrm{~cm} \text {, massive) and clay-rich mud (top } 12 \\
\mathrm{~cm} \text {, root stains, gypsum crystals) in upward-fining bed } \\
\text { couplet; interval top and base are sharp. }\end{array}$ \\
\hline 40 & 9 & 9.41 & 4 & $\mathrm{~F}$ & 212.39 & Fine sand $(7 \mathrm{~cm})$ overlain by $2 \mathrm{~cm}$ mud; sharp base and top. \\
\hline 39 & 4 & 9.32 & 6 & $\mathrm{~F}$ & 212.30 & Sand $(2 \mathrm{~cm})$ fining upward to mud $(2 \mathrm{~cm})$; sharp base and top. \\
\hline 38 & 70 & 9.28 & 6 & $\mathrm{~F}$ & 212.26 & $\begin{array}{l}\text { Fine sand ( } 80 \%) \text { in beds } 5 \text { to } 20 \mathrm{~cm} \text { thick, each fining upward } \\
\text { to clayey silt. }\end{array}$ \\
\hline 37 & 80 & 8.58 & 6 & $\mathrm{~F}$ & 211.56 & Like the overlying interval; also cliff forming. \\
\hline 36 & 27 & 7.78 & 3 & $\mathrm{~F}$ & 210.76 & $\begin{array}{l}\text { Clayey silt; root stains (initially described in field in } \\
\text { combination with the } 2 \text { underlying intervals as an } 80-\mathrm{cm} \\
\text { interval of less resistant fine sand). }\end{array}$ \\
\hline 35 & 13 & 7.51 & 4 & $\mathrm{~F}$ & 210.49 & Fine sand bed grading upward to lesser amount of mud. \\
\hline 34 & 40 & 7.38 & 6 & $\mathrm{~F}$ & 210.36 & $\begin{array}{l}\text { Fine sand bed fining upward to lesser amount of mud; } \\
\text { resistant. }\end{array}$ \\
\hline 33 & 25 & 6.98 & 3 & $E$ & 209.96 & $\begin{array}{l}\text { Muddy silt fining upward to silty clay and clay in } 1 \text { bed; roots } \\
\text { and horizontal plant impressions. }\end{array}$ \\
\hline 32 & 5 & 6.73 & 4 & $E$ & 209.71 & Thinner bed similar to above. \\
\hline
\end{tabular}


Table 7. Detailed type section of the Chemehuevi Formation next to the Katherine Ranger Station, Ariz.-Continued [Measured by D. Malmon and K. Howard]

\begin{tabular}{|c|c|c|c|c|c|c|}
\hline Interval No. & $\begin{array}{l}\text { Interval } \\
\text { Thickness (cm) }\end{array}$ & $\begin{array}{l}\text { Cumulative } \\
\text { Thickness (m) }\end{array}$ & $\begin{array}{c}\text { Relative } \\
\text { Resistance }^{2}\end{array}$ & $\begin{array}{l}\text { Alphabetic } \\
\text { Interval }^{3}\end{array}$ & $\begin{array}{l}\text { Elevation of } \\
\text { Top of Interval } \\
(\mathrm{m})^{4}\end{array}$ & Description \\
\hline 31 & 5 & 6.68 & 5 & $\mathrm{E}$ & 209.66 & Thin bed similar to next two intervals above. \\
\hline 30 & 15 & 6.63 & 6 & $E$ & 209.61 & More beds similar to the overlying 3 intervals. \\
\hline 29 & 155 & 6.48 & 6 & $\mathrm{D}$ & 209.46 & $\begin{array}{l}\text { Fine to medium sand, poorly bedded; four } 1 \text { to } 2-\mathrm{cm} \text { mud } \\
\text { beds; locally sand "beds" coarsen upward from fine sand to } \\
\text { medium-coarse sand; some thin beds of lithic-rich sand; } \\
\text { resistant. }\end{array}$ \\
\hline 28 & 15 & 4.93 & 7 & $\mathrm{D}$ & 207.91 & $\begin{array}{l}\text { Gravelly sand, heterogeneous, clast-supported; pebbles } \\
\text { subangular, as large as } 10 \mathrm{~cm} \text { (intermediate diameter) of white } \\
\text { grante withcataclasite zone, and dark rocks. }\end{array}$ \\
\hline 27 & 65 & 4.78 & 5 & $\mathrm{D}$ & 207.76 & $\begin{array}{l}\text { Fine sand, thin-bedded, in beds with six } 1 \text { to } 2-\mathrm{cm} \text {-thick clay } \\
\text { layers; resistant. }\end{array}$ \\
\hline 26 & 35 & 4.13 & 5 & $\mathrm{D}$ & 207.11 & Sand, thin bedded; two $1 \mathrm{~cm}$ brown clayey mud beds. \\
\hline 25 & 5 & 3.78 & 5 & $\mathrm{D}$ & 206.76 & $\begin{array}{l}\text { Pebbly coarse sand, abundant lithics, grades laterally into } \\
\text { sandy gravel with fine subangular pebbles. }\end{array}$ \\
\hline \multicolumn{7}{|c|}{ Mud Facies and Valley Margin Facies } \\
\hline 24 & 3 & 3.73 & 4 & $\mathrm{C}$ & 206.71 & Fine sand lens. \\
\hline 23 & 5 & 3.70 & 4 & $\mathrm{C}$ & 206.68 & Very coarse sand, lithic rich. \\
\hline 22 & 10 & 3.65 & 4 & $\mathrm{C}$ & 206.63 & Medium sand. \\
\hline 21 & 3.5 & 3.55 & 3 & $\mathrm{C}$ & 206.53 & Brown clay. \\
\hline 20 & 10 & 3.51 & 4 & $\mathrm{C}$ & 206.49 & Fine sand; may be paired with overlying clay. \\
\hline 19 & 4 & 3.41 & 4 & $\mathrm{C}$ & 206.39 & Clay, red-brown. \\
\hline 18 & 17 & 3.37 & 4 & $\mathrm{C}$ & 206.35 & Fine sand; may be paired with overlying clay. \\
\hline 17 & 4 & 3.20 & 4 & $\mathrm{C}$ & 206.18 & Coarse sand, lithic rich. \\
\hline 16 & 4 & 3.16 & 3 & C & 206.14 & Clay, pale cream-colored. \\
\hline 15 & 15 & 3.12 & 3.5 & $\mathrm{C}$ & 206.10 & Sand, partly lithic-rich in cyclic intervals but ill-defined as beds. \\
\hline 14 & 35 & 2.97 & 4 & $\mathrm{C}$ & 205.95 & $\begin{array}{l}\text { Sand and mud: interbedded lithic-rich sand, mud, and well } \\
\text { sorted, light-toned quartz sand. }\end{array}$ \\
\hline 13 & 10 & 2.62 & 4 & C & 205.60 & Clay, red. \\
\hline 12 & 15 & 2.52 & 4 & $\mathrm{C}$ & 205.50 & Sand, fine to medium. \\
\hline 11 & 3 & 2.37 & 4 & C & 205.35 & Sand, medium to coarse, lithic rich. \\
\hline 10 & 9 & 2.34 & 4 & C & 205.32 & Sand, fine, yellowish; horizontal rusty plant stains. \\
\hline 9 & 15 & 2.25 & 5 & C & 205.23 & Sand, fine, well consolidated. \\
\hline 8 & 30 & 2.10 & 6 & B & 205.08 & $\begin{array}{l}\text { Cobble gravel, clast supported, subangular, possibly } \\
\text { imbricated; pebbles to cobbles to (?) rare boulders. }\end{array}$ \\
\hline
\end{tabular}


[Measured by D. Malmon and K. Howard]

\begin{tabular}{|c|c|c|c|c|c|c|}
\hline Interval No. & $\begin{array}{l}\text { Interval } \\
\text { Thickness (cm) }\end{array}$ & $\begin{array}{l}\text { Cumulative } \\
\text { Thickness (m) }\end{array}$ & $\begin{array}{c}\text { Relative } \\
\text { Resistance }^{2}\end{array}$ & $\begin{array}{l}\text { Alphabetic } \\
\text { Interval }^{3}\end{array}$ & $\begin{array}{c}\text { Elevation of } \\
\text { Top of Interval } \\
(\mathrm{m})^{4} \\
\end{array}$ & Description \\
\hline 7 & 40 & 1.80 & 6 & A & 204.78 & $\begin{array}{l}\text { Sandy pebble gravel, poorly sorted, interbedded complexly } \\
\text { with well sorted sand and cemented sandstone }(50 \%) \text {. }\end{array}$ \\
\hline 6 & 55 & 1.40 & 3 & A & 204.38 & Silty fine sand, well sorted. \\
\hline 5 & 5 & 0.85 & 3 & A & 203.83 & Mud lens. \\
\hline 4 & 10 & 0.80 & 3 & A & 203.78 & Silty fine sand. \\
\hline \multirow[t]{2}{*}{1} & 60 & 0.60 & 6 & A & $\begin{array}{l}203.58 \\
202.98\end{array}$ & $\begin{array}{l}\text { Subangular cobble gravel, } \pm \text { sand lenses. } \\
\text { Base of exposure; GPS } 07-424-7 \text {. }\end{array}$ \\
\hline & $\sim 400$ & & 4 & & & $\begin{array}{l}\text { Interfingering angular conglomerate and sandstone seen } \\
\text { laterally around to the west where exposed. }\end{array}$ \\
\hline
\end{tabular}

${ }^{1}$ GPS data for points measured on the type section; from appendix 1.

${ }^{2}$ Relative resistance to erosion estimated on subjective scale from 0 to 6 , with 6 being most resistant (vertical).

${ }^{3}$ Alphabetic assignment corresponding to the summary type section in figure 24.

${ }^{4}$ Elevation computed by adding cumulative measured thickness to the GPS-measured elevation at base of section. The discrepancy between elevations within measured section and the GPS elevation at survey points on section (for example, 07-424-6) are due to the combination of GPS error and vertical outcrop measurement error. 


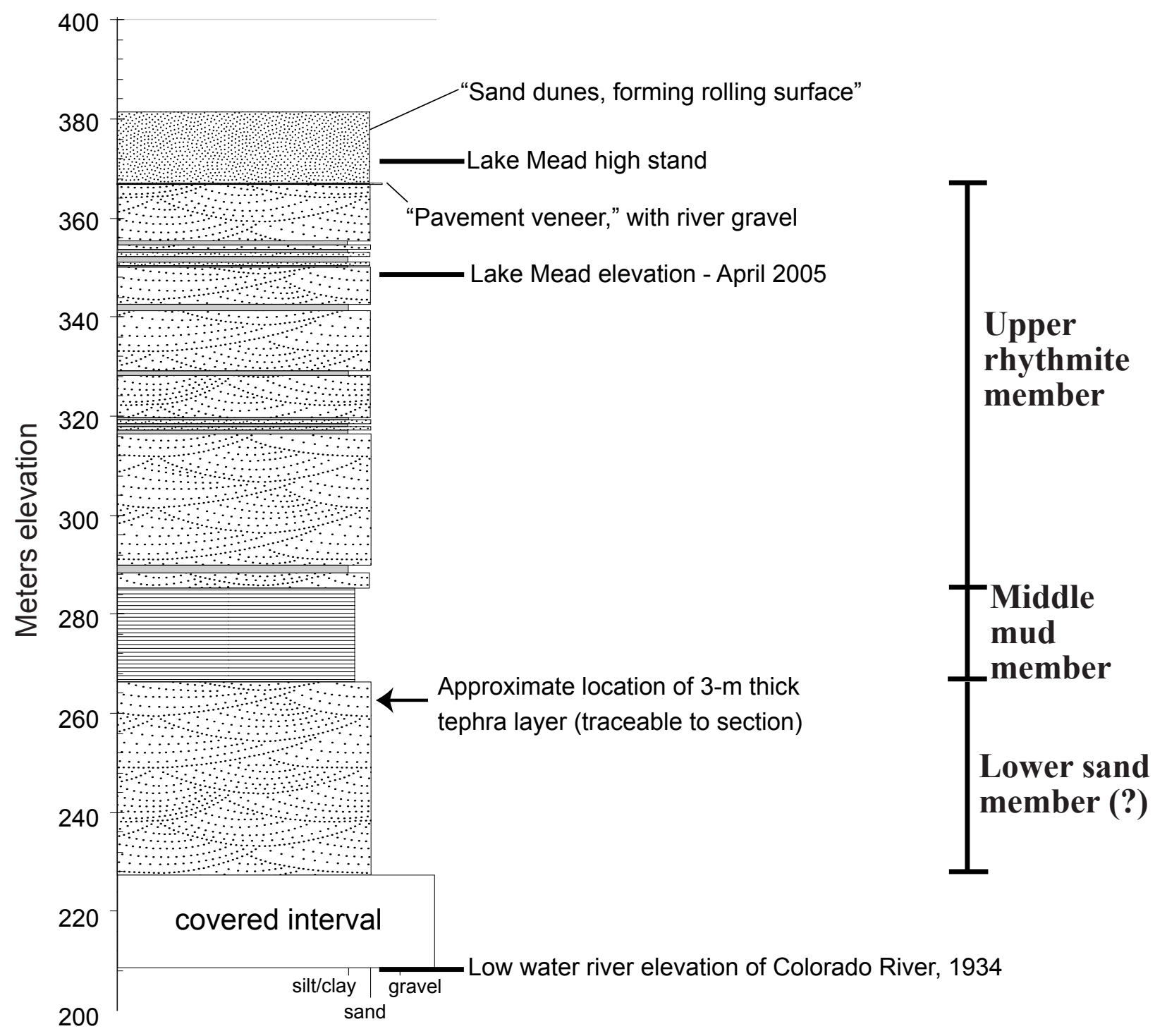

\section{EXPLANATION}

Sand dunes, eolian

Silt and (or) clay

Sand or cross-bedded sand

Coarse sand with scattered layers of clay and silt

Figure 28. Reference section of the Chemehuevi Formation at Old Callville, Nev., as measured by Longwell (1936, p. 14451446). See figure 12 or location and appendix 4 for detailed description of section. Figure 4 is Longwell's (1936) pre-dam aerial photograph showing this outcrop. This section is mostly submerged beneath Lake Mead, and no clearly river-lain sediment was observed when visited by the authors by boat in April, 2005. The upper member of this section is considered to be the rhythmite facies of the formation as described in this report, and the middle member is typical of the mud facies. Longwell (1936) included the poorly exposed lower sandy member (below $\sim 265 \mathrm{~m}$ elevation) in his Chemehuevis Formation. However, we are uncertain whether this lower member and its tephra bed belong to the Chemehuevi Formation as used in this report. 
tephra layers in Owens Lake and Walker Lake constrain the age of those possibly correlative tephra to between 70 and 74 ky ago. Even if the tephra in Owens and Walker Lakes are not correlative to those in the Chemehuevi Formation, multiple lines of stratigraphic evidence are consistent with the tephra and the formation having been deposited during Marine Oxygen Isotope Stage 4 (between 74 and $59 \mathrm{ka}$ ).

The characteristics of and relationships among the different facies in outcrops, and the stratigraphic architecture of the formation lead to an interpretation of the deposits as the remnants of a single major fluvial aggradational episode, caused primarily by an increase in the ratio of supply to transport capacity of sand-rich, bed-material-sized sediment. Regional climatic change is one explanation for such a sediment pulse; however, other explanations have not been ruled out.

\section{Acknowledgments}

This work benefited from contributions of expertise and support of many individuals. Andy Calvert and Dean Miller (USGS, Menlo Park) helped with ${ }^{40} \mathrm{Ar}-{ }^{39} \mathrm{Ar}$ dating of tephra samples; Matthew Kirby of California State University at Fullerton analyzed samples for particle size; Jordon Bright (Northern Arizona University) examined samples for ostracodes; Charles Powell II (USGS, Menlo Park) examined gastropod specimens; and Tracey Felger (USGS, Flagstaff) conducted GIS analyses and helped us compile digital data. Charles Powell II, Scott Starratt (USGS, Menlo Park), and Sean Connell (New Mexico Bureau of Mines and Geology) provided input on stratigraphic rules and nomenclature. Wes Hildreth (USGS, Menlo Park) provided samples of Mammoth Mountain pumice for geochemical analysis as well as valuable input on regional geology and tephra interpretations. The Fort Mojave Indian Reservation and the Colorado River Indian Tribes granted access to tribal lands and helped facilitate field work and group field trips. Access, sampling permissions, and water transportation were provided by the personnel of Lake Mead National Recreation Area. Conversations with Zach Anderson, Sue Beard, John Bell, Luke Blair, James Faulds, Tracey Felger, Richard Hereford, David Miller, Donald Metzger, Jim O’Connor, Steve Reneau, Bob Reynolds, Tammy Rittenour, John Whitney, and others who have participated in discussions in the field and elsewhere, contributed to our understanding and interpretations. The manuscript was improved as a result of thoughtful reviews by Sean Connell, Wes Hildreth, Jim O'Connor (USGS, Portland), and Marith Reheis (USGS, Denver). This work was completed with the support of the U.S. Geological Survey Mendenhall Postdoctoral Research Fellowship Program and the National Cooperative Geologic Mapping Program (Geology of Southwest Parks and Public Lands Project).

\section{References Cited}

Agenbroad, L.D., Mead, J.I., and Reynolds, R.E., 1992, Mammoths in the Colorado River corridor: San Bernardino
County Museum Special Publication 92-2, p. 104-106.

Anders, M.D., Pederson, J.L., Rittenour, T.M., Sharp, W. D., Gosse, J.C., Karlstrom, K.E., Crossey, L.J., Goble, R.J., Stockli, L., and Yang, G., 2005, Pleistocene geomorphology and geochronology of eastern Grand Canyon-linkages of landscape components during climate changes: Quaternary Science Reviews, v. 24, no. 23-24, p. 2428-2448.

Bada, J.L., 1975a, Amino-acid racemization results of vertebrate samples from Parker and Ehrenberg, Arizona, early site review report (archived), Sundesert Nuclear Power Project, appendix 2.5J, addendum 2(b): Los Angeles, Southern California Edison Company, 5 p.

Bada, J.L., 1975b, Preliminary amino-acid racemization dating of mammoth bone from Parker, Arizona, early site review report (archived), Sundesert Nuclear Power Project, appendix 2.5J, addendum 2(a): Los Angeles, Southern California Edison Company, 4 p.

Bales, J.T., and Laney, R.L., 1992, Geohydrologic reconnaissance of Lake Mead National Recreation Area-Las Vegas Wash to Virgin River, Nevada: USGS Water-Resources Investigations Report 91-4185.

Bell, J.W., Ku, T.-L., and Kukla, G. J., 1978, The Chemehuevi Formation of Nevada, Arizona, and California - an examination of its distribution, facies, and age: Geological Society of America Abstracts With Programs, v. 10, no. 3, p. 95.

Bell, J.W., dePolo, C.M, Ramelli, A.R., Sarna-Wojcicki, A.M., and Meyer, C.E., 1999, Surface faulting and paleoseismic history of the 1932 Cedar Mountain earthquake area, westcentral Nevada, and implications for modern tectonics of the Walker Lane: Geological Society of America Bulletin, v. 111, p. 791-807.

Benson, L.V., May, H.M., Antweiler, R.C., Brinton, T.I., Kashgarian, M., Smoot, J.P., and Lund, S.P., 1998, Continuous lake-sediment records of glaciation in the Sierra Nevada between 52,600 and $12,500{ }^{14} \mathrm{C}$ yr BP: Quaternary Research, 50, p. 113-127.

Blackwelder, E., 1934, Origin of the Colorado River: Bulletin of the Geological Society of America, v. 45, no. 3, p. 551566.

Blair, J.L., 1996, Drastic modification of the depositional style of the lower Colorado River in late Pleistocene time - evidence from fine-grained strata in the Lake Mohave area, Nevada/Arizona: Vanderbilt University, unpub. M.S. thesis, $138 \mathrm{p}$.

Borchardt, G.A., 1974, The SIMAN coefficient for similarity analysis: Classification Society Bulletin, v. 3, no. 2, p. 7-11.

Bull, W.B., 1975, Geomorphic tectonic analysis of the Vidal region, information concerning site characteristics, Vidal Nuclear Generating Station (California), appendix 2.5B: 
Los Angeles, Southern California Edison Company, 66 p.

Cassiliano, M.L., 2002, Revision of the stratigraphic nomenclature of the Plio-Pleistocene Palm Spring Group (new rank), Anza Borrego Desert, southern California: Proceedings of the Sandiego Society of Natural History, 38, $30 \mathrm{p}$.

Connell, S.D., Love, D.W., and Dunbar, N.W., 2007, Geomorphology and stratigraphy of inset fluvial deposits along the Rio Grande valley in the central Albuquerque basin, New Mexico: New Mexico Geology, v. 29, no. 1, p. 13-31.

Diblee, T.W., Jr., 1954, Geology of the Imperial Valley region, California, in Jahns, R.H., ed, Geology of Southern California: California Division of Mines Bulletin 170, p. 21-28.

Diblee, T.W., Jr., 1984, Stratigraphy and tectonics of the San Felepe Hills, Borrego Badlands, Superstition Hills, and vicinity, in Rigsby, C.A., ed., The Imperial Basin - tectonics, sedimentation, and thermal aspects: Pacific Section Society of Economic Paleontologists and Mineralogists Field Trip Guidebook, v. 40, p. 31-44.

Dickey, D.D., Carr, W.J., and Bull, W.B., 1980, Geologic map of the Parker NW, Parker, and parts of the Whipple Mountains SW and Whipple Wash quadrangles, California and Arizona: U.S. Geological Survey Miscellaneous Investigations Series Map I-1124, scale 1:24,000.

Dickinson, J.E., Land, M., Faunt, C.C., Leake, S.A., Reichard, E.G., Fleming, J.B., and Pool, D.R., 2006, Hydrogeologic framework refinement, ground-water flow and storage, water-chemistry analyses, and water-budget components of the Yuma area, southwestern Arizona and southeastern California: U. S. Geological Survey Scientific Investigations Report 2006-5135, 90 p.

Fairbanks, R.G., Mortlock, R.A., Chiu, T.C., Cao, L., Kaplan, A., Guilderson, T.P., Fairbanks, T. W., Bloom, A.L., Grootes, P.M., and Nadeau, M.J., 2005, Radiocarbon calibration curve spanning 0 to 50,000 years BP based on paired Th-230/U-234/U-238 and C-14 dates on pristine corals: Quaternary Science Reviews, v. 24 no. 16-17, p. 1781-1796.

Faulds, J.E., 1996a, Geologic map of the Fire Mountain 7. 5' quadrangle, Nevada and Arizona: Nevada Bureau of Mines and Geology Map Map 106, scale 1:24,000, 6 p. text.

Faulds, J.E., 1996b, Geologic map of the Mt. Davis 7.5' quadrangle, Nevada and Arizona: Nevada Bureau of Mines and Geology Map 105, scale 1:24,000, 46 p. text.

Faulds, J.E., House, P.K., Pa, P., Bell, J.W., and Ramelli, A.R., 2004, Preliminary geologic map of the Davis Dam Quadrangle and eastern part of the Bridge Canyon Quadrangle, Clark County, Nevada, and Mohave County, Arizona: Nevada Bureau of Mines Open-File Report 03-5, scale $1: 24,000$.
Faure, G., 1986, Principles of Isotope Geochemistry: Wiley, New York, 589 p.

Fugro, Inc., 1975, Early site review report, Sundesert Nuclear Power Project: Southern California Edison Company.

Hildreth, W., 2004, Volcanological perspectives on Long Valley, Mammoth Mountain, and Mono Craters - several contiguous but discrete systems: Journal of Volcanology and Geothermal Research, v. 136, no. 3-4, p. 169-198.

House, P.K., Howard, K.A., Bell, J.W., and Pearthree, P.A., 2004, Preliminary geologic map of the Arizona and Nevada parts of the Mt. Manchester Quadrangle: Nevada Bureau of Mines and Geology Open-file Report 04-04, scale 1:24,000.

House, P.K., Brock, A.L., and Pearthree, P.A., 2005a, Geologic map of late Cenozoic alluvial deposits in the Spirit Mountain Southeast quadrangle: Nevada Bureau of Mines and Geology Open-File Report 05-8, scale 1:24,000.

House, P.K., Pearthree, P.A., Howard, K.A., Bell, J.W., Perkins, M.E., Faulds, J.E., and Brock, A.L., 2005b, Birth of the lower Colorado River-stratigraphic and geomorphic evidence for its inception near the conjunction of Nevada, Arizona, and California, in Pedersen, J., and Dehler, C.M., eds., Interior Western United States: Geological Society of America Field Guide, Geological Society of America, p. 357-387.

Howard, K.A., and Malmon, D.V., 2007, Stratigraphy of lower Mohave Valley, in Reynolds, R. E., ed., The 2007 Desert Symposium field guide: California State University, Desert Studies Consortium, p. 50-56.

Howard, K.A., Lundstrom, S.C., Malmon, D.V., and Hook, S.J., 2008, Age, distribution, and formation of late Cenozoic paleovalleys of the lower Colorado River and their relation to river aggradation and degradation, in Reheis, M.C., Hershler, R., and Miller, D.M., eds, Late Cenozoic drainage history of the wouthwestern Great Basin and lower Colorado River region - geologic and biotic perspectives: Geological Society of America Special Paper 439 , p. 391-410.

Ives, J.C., 1861, Report Upon the Colorado River of the West, 36th Congress 1st session, Senate: Washington, D.C., Government Printing Office, $154 \mathrm{p}$.

John, B.E., 1987, Geologic map of the Chemehuevi Mountains area San Bernardino County, California, and Mohave County, Arizona: U. S. Geological Survey Open-File Report 87-666, scale 1:24,000.

Ku, T.L., 1975, Age dating of desert caliche by Th230/U234, early site review report (archived), Sundesert Nuclear Power Project, appendix 2.5J, addendum 3: Los Angeles, Southern California Edison Company, 5 p. 
Kukla, G.J., 1975, Preliminary report on the magnetostratigraphy study of sediments near Blythe, California and Parker Valley, Arizona, early site review report (archived), Sundesert Nuclear Power Project, appendix 2.5B: Los Angeles, Southern California Edison Company, $10 \mathrm{p}$.

Lajoie, K., 1968, Late quaternary stratigraphy and geologic history of Mono Basin, eastern California: University of California, Berkeley, unpub. Ph.D. dissertation, $271 \mathrm{p}$.

Lambert, P.W., 1968, Quaternary stratigraphy of the Albuquerque area, New Mexico: University of New Mexico, unpub. Ph.D. dissertation, $329 \mathrm{p}$.

Lee, G.K., and Bell, J.W., 1975, Depositional and geomorphic history of the lower Colorado River, early site review report (archived), Sundesert Nuclear Power Project, appendix 2.5B: Los Angeles, Southern California Edison Company, $25 \mathrm{p}$.

Lee, W.T., 1908, Geologic reconnaissance of a part of western Arizona: U. S. Geological Survey Bulletin 0352, 96 p.

Longwell, C.R., 1936, Geology of the Boulder Reservoir floor: Geological Society of America Bulletin, v. 47, no. 9, p. 1393-1476.

Longwell, C.R., 1946, How old is the Colorado River?: American Journal of Science, v. 244, no. 12, p. 817-835.

Longwell, C.R.,1960, Geologic setting of Lake Mead, in Smith, W.O., Vetter, C.P., and Cummings, G.B., eds., Comprehensive survey of sedimentation in Lake Mead, 1948-1949: U. S. Geological Survey Professional Paper 295, p. 11-20.

Longwell, C.R., 1963, Reconnaissance geology between Lake Mead and Davis Dam: Arizona-Nevada: U.S. Geological Survey Professional Paper 374-E, 51 p.

Longwell, C.R., Pampeyan, E.H., Bowyer, B., and Roberts, R. J., 1965, Geology and mineral deposits of Clark County, Nevada: Nevada Bureau of Mines and Geology Bulletin, v. 62, p. 218.

Lucchitta, I., 1966, Cenozoic geology of the upper Lake Mead area adjacent to the Grand Wash Cliffs, Arizona: Pennsylvania State University, Ph.D. dissertation, 274 p.

Lundstrom, S.C., Mahan, S., Paces, J., Hudson, M., House, P.K., Malmon, D., Blair, J. L., and Howard, K.A., 2008, Late Pleistocene aggradation and degradation of the lower Colorado River - perspectives from the Cottonwood area and other reconnaissance below Boulder Canyon, in Reheis, M.C., Hershler, R., and Miller, D.M., eds., Late Cenozoic drainage history of the southwestern Great Basin and Lower Colorado River region - geologic and biotic perspectives, $\mathrm{p}$. 409-430.
Machette, M.N., 1985, Calcic soils of the southwestern United States, in Weide, D.L., ed., Quaternary soils and geomorphology of the American Southwest: Geological Society of America Special Paper 203, p. 1-21.

Malmon, D.V., Howard, K.A., and Priest, S.S., 2009a, Geologic map of the Needles 7.5' quadrangle, California and Arizona: U. S. Geological Survey Scientific Investigations Map 3062, scale 1:24,000, 1 sheet, 31 p. pamphlet.

Malmon, D.V., Felger, T.J, and Howard, K.A., and, 2009b,

Geologic considerations for the placement and design of backwater restoration projects along the lower Colorado River, in Melis, T.S., Hamill, J.F., Coggins, L.C., Jr., Grams, P.E., Kennedy, T.A., Kubly, D.M., and Ralston, B. E., eds., Proceedings of the Colorado River Basin Science and Resource Management Symposium, November 18-20, 2008, Scottsdale, Arizona: U.S. Geological Survey Scientific Investigations Report 2010-5135, p. 307-316.

Martinson, D.G., Pisias, N.G., Hays, J.D., Imbrie, J., Moore, Jr., T.C., and Shakleton, N.J., 1987, Age dating and the orbital theory of the ice ages - development of a highresolution 0 to 300,000-year chronostratigraphy: Quaternary Research 27, 1-29.

Metzger, D.G., 1968, The Bouse Formation (Pliocene) of the Parker-Blythe-Cibola area, Arizona and California: U. S. Geological Survey Professional Paper 600-D, p. D126-D136.

Metzger, D.G., and Loeltz, O.J., 1973, Geohydrology of the Needles area, Arizona, California, and Nevada: U. S. Geological Survey Professional Paper 486-J, 54 p.

Metzger, D.G., Loeltz, O.J., and Irelan, B., 1973, Geohydrology of the Parker-Blythe-Cibola area, Arizona, California, and Nevada: U. S. Geological Survey Professional Paper 486-G, $130 \mathrm{p}$.

Miall, A.D., 2006, The Geology of Fluvial Deposits: Berlin, Springer, $582 \mathrm{p}$.

Munsell Company, 1992, Soil color chart: New York, Munsell Company, Kollmorgen Instruments Corporation.

North American Commission on Stratigraphic Nomenclature, 2005, North American Stratigraphic Code: American Association of Petroleum Geologists Bulletin, v. 89, no. 11, p. $1547-1591$.

Olmsted, R.H., Loeltz, O.J., and Irelan, B., 1973, Geohydrology of the Yuma area, Arizona and California: U.S. Geological Survey Professional Paper 0486-H, 227 p.

Pearthree, P.A., 1998, Quaternary fault data and map for Arizona: Arizona Geological Survey Open-File Report 98-24, 122 p., scale 1:750,000.

Pearthree, P.A., and House, P.K., 2005, Digital geologic map of the Davis Dam Southeast Quadrangle, Mohave 
County, Arizona, and Clark County, Nevada Arizona Geological Survey Digital Geologic Map DGM-45, scale $1: 24,000$.

Ring, J.H., 2000, Young volcanism in western Long Valley, California: Stanford University, M.S. thesis, 106 p.

Sarna-Wojcicki, A.M., Lajoie, K.R., Meyer, C.E., Adam, D.P., Robinson, S.W., and Anderson, R.S., 1988, Tephrochronologic studies of sediment cores from Walker Lake, Nevada: U.S. Geological Survey Open-File Report 88-548, 25 p., 11 figures, 4 tables.

Sarna-Wojcicki, A.M., Meyer, C.E., and Wan, Elmira, 1997, Age and correlation of tephra layers, position of the Matuyama-Brunhes chron boundary, and effects of Bishop ash eruption on Owens lake, as determined from drill hole OL-92, southeast California, in Smith, G.I., and Bischoff, J.L., eds., An 800,000-year paleoclimatic record from Core OL-92, Owens Lake, southeast California: Geological Society of America Special Paper 317, p. 79-90.

Sarna-Wojcicki, A.M., 2000, Tephrochronology, in Noller, J.S., Sowers, J.M., and Lettis, W.R., eds., Quaternary geochronology - methods and applications: American Geophysical Union Reference Shelf 4, p. 357-377.

Schumm, S.A., and Khan, H.R., 1972, Experimental study of channel patterns: Geological Society of America Bulletin, v. 83 , no. 6 , p. $1755-1770$.

Shaw, E.W., 1911, Preliminary statement concerning a new system of Quaternary lakes in the Mississippi Basin: Journal of Geology, v. 19, p. 481-491.

Stauffer, H., 2003, Timing of the last high stand of Pluvial
Lake Wellington, Smith Valley, Nevada: San Jose State University, unpub. M.S. thesis, $121 \mathrm{p}$.

Stone, P., 2006, Geologic Map of the west half of the Blythe 30 ' by 60' quadrangle, Riverside County, California and La Paz County, Arizona, U. S. Geological Survey Scientific Investigations Map 2922, scale 1:100,000, 1 sheet, 21 p. pamphlet.

Taylor, D.W., 1982, Late Tertiary mollusks from the lower Colorado River valley: University of Michigan, Contributions from the Museum of Paleontology, v. 26, no. 13, p. 289-298.

Thornbury, W.D., Glacial sluiceways and lacustrine plains of southern Indiana, 1950: Indiana Geological Survey Bulletin, B04, $21 \mathrm{p}$.

U.S. Geological Survey, 1927, Plan and profile of the Colorado River from Black Canyon, Ariz.-Nev. to ArizonaSonora boundary: U.S. Geological Survey, 20 sheets, scale $1: 31,680$.

Wallace, M.A., Faulds, J.E., and Brady, R.J., 2005, Geologic map of the Meadview North quadrangle, Mohave County, Arizona, and Clark County, Nevada: Nevada Bureau of Mines and Geology Map M 154, scale 1:24,000.

Winker, C.D., 1987, Neogene stratigraphy of the Fish Creek-Vallecito section, southern California-implications for early history of the northern Gulf of California and Colorado Delta: University of Arizona, Ph.D. dissertation, 494 p.

Woodward-McNeill and Associates, 1977, Information concerning site characteristics; Vidal Nuclear Generating Station: Southern California Edison Company, 5 volumes. 
This page intentionally left blank 
Appendixes 1-9 
Appendix 1. Descriptions and location data for outcrops of the Chemehuevi Formation throughout the lower Colorado River Valley.

[Data collected using a Trimble GeoXT handheld GPS unit while standing on outcrops and postprocessed using simultaneous data from nearby fixed base stations]

\begin{tabular}{|c|c|c|c|c|c|c|c|}
\hline Locality Index & Latitude & Longitude & $\begin{array}{c}\text { Valley } \\
\text { Distance } \\
(\mathrm{km})\end{array}$ & Elevation $^{2}(\mathrm{~m})$ & Facies & Location and Notes ${ }^{3}$ & 7.5' Quadrangle \\
\hline $05-15 a$ & 34.566 & -114.394 & 393.0 & 161.4 & sand/mud contact & Castle Rock-abrupt sand-over-mud contact. & Castle Rock \\
\hline $05-17 a$ & 34.579 & -114.407 & 394.6 & 150.3 & sand/mud contact & N. of Castle Rock-abrupt sand-over-mud contact. & Castle Rock \\
\hline $05-17 b$ & 34.581 & -114.408 & 394.8 & 189.3 & sand & N. of Castle Rock—local highest sand facies. & Castle Rock \\
\hline $05-18 b$ & 34.819 & -114.487 & 424.9 & 218.1 & sand & N. of Castle Rock—local highest sand facies. & Castle Rock \\
\hline $05-7 a$ & 35.185 & -114.578 & 470.7 & 222.3 & sand/mud contact & $\begin{array}{l}\text { Davis Dam bluffs - sand-over-mud ctc mud rip-up } \\
\text { clasts in sand facies }\end{array}$ & Davis Dam \\
\hline 05-20a & 35.178 & -114.576 & 470.0 & 198.5 & sand/mud contact & $\begin{array}{l}\text { Davis Dam bluffs_local sand-over-mud ctc near } \\
\text { soil-mantled unconformity. }\end{array}$ & Davis Dam \\
\hline $05-21$ & 36.128 & -114.884 & $\mathrm{n} / \mathrm{a}$ & 388.4 & $\begin{array}{c}\text { tributary - Las Vegas } \\
\text { Wash }\end{array}$ & Las Vegas Wash—local highest layered mud. & \\
\hline $05-28 a$ & 35.479 & -114.694 & 504.9 & 261.4 & sand/mud contact & S. of Cottonwood Cove-sand-over-mud contact. & Spirit Mtn NW \\
\hline $05-27 b$ & 35.479 & -114.693 & 504.9 & 264.1 & sand & S. of Cottonwood Cove-local highest sand facies. & Spirit Mtn NW \\
\hline $05-29 b$ & 35.479 & -114.693 & 504.8 & 266.0 & sand & S. of Cottonwood Cove-local highest sand facies. & Spirit Mtn NW \\
\hline $05-29 a$ & 35.479 & -114.693 & 504.8 & 256.7 & sand/mud contact & S. of Cottonwood Cove-sand-over-mud contact. & Spirit Mtn NW \\
\hline $05-30 b$ & 35.478 & -114.692 & 504.8 & 267.4 & sand & S. of Cottonwood Cove-local highest sand facies. & Spirit Mtn NW \\
\hline 05-30a & 35.478 & -114.692 & 504.8 & 255.6 & sand/mud contact & S. of Cottonwood Cove-sand-over-mud contact. & Spirit Mtn NW \\
\hline 05-31b & 35.478 & -114.690 & 504.8 & 271.1 & sand & S. of Cottonwood Cove-local highest sand facies. & Spirit Mtn NW \\
\hline 05-31a & 35.478 & -114.691 & 504.7 & 255.6 & sand/mud contact & S. of Cottonwood Cove-sand-over-mud contact. & Spirit Mtn NW \\
\hline $05-32 b$ & 35.478 & -114.690 & 504.8 & 269.9 & sand & S. of Cottonwood Cove-local highest sand facies. & Spirit Mtn NW \\
\hline $05-32 a$ & 35.478 & -114.690 & 504.7 & 255.1 & sand/mud contact & S. of Cottonwood Cove-sand-over-mud contact. & Spirit Mtn NW \\
\hline
\end{tabular}


Appendix 1. Descriptions and location data for outcrops of the Chemehuevi Formation throughout the lower Colorado River Valley.-Continued

[Data collected using a Trimble GeoXT handheld GPS unit while standing on outcrops and postprocessed using simultaneous data from nearby fixed base stations]

\begin{tabular}{|c|c|c|c|c|c|c|c|}
\hline Locality Index & Latitude & Longitude & $\begin{array}{l}\text { Valley } \\
\text { Distance }^{1} \\
\quad(\mathbf{k m})\end{array}$ & $\begin{array}{l}\text { Elevation } \\
\quad(\mathrm{m})\end{array}$ & Facies & Location and Notes ${ }^{3}$ & 7.5' Quadrangle \\
\hline $05-32 a$ & 35.478 & -114.690 & 504.7 & 255.1 & sand/mud contact & S. of Cottonwood Cove-sand-over-mud contact. & Spirit Mtn NW \\
\hline 05-33b & 35.478 & -114.687 & 504.7 & 260.7 & sand & $\begin{array}{l}\text { S. of Cottonwood Cove-top of sand nr buttress } \\
\text { unconformity at eastern edge of otc. }\end{array}$ & Spirit Mtn NW \\
\hline 05-33a & 35.478 & -114.688 & 504.7 & 257.6 & sand/mud contact & $\begin{array}{l}\text { S. of Cottonwood Cove-sand-over-mud ctc along } \\
\text { buttress unconformity top of Lundstrom sample } \\
\text { section W-W'. }\end{array}$ & Spirit Mtn NW \\
\hline 05-35 & 35.477 & -114.689 & 504.7 & 246.5 & mud & $\begin{array}{l}\text { S. of Cottonwood Cove-w/in mud facies at contact } \\
\text { btwn red beds (above) and gray/green beds } \\
\text { (below), nr section W-W'. }\end{array}$ & Spirit Mtn NW \\
\hline $05-36$ & 35.477 & -114.689 & 504.7 & 252.5 & mud & $\begin{array}{l}\text { S. of Cottonwood Cove-w/in mud facies at thin } \\
\text { yellow layer, nr section W-W'. }\end{array}$ & Spirit Mtn NW \\
\hline $05-37$ & 35.477 & -114.689 & 504.7 & 244.7 & mud & $\begin{array}{l}\text { S. of Cottonwood Cove-in mud facies, layer with } \\
\text { rounded quartzite pebbles, nr section W-W'. }\end{array}$ & Spirit Mtn NW \\
\hline $05-38$ & 35.477 & -114.689 & 504.7 & 236.0 & mud & $\begin{array}{l}\text { S. of Cottonwood Cove-local lowest exposure of } \\
\text { mud facies, near base of section W-W'. }\end{array}$ & Spirit Mtn NW \\
\hline $05-39$ & 35.179 & -114.565 & 470.4 & 168.2 & mud & $\begin{array}{l}\text { E. side river below Davis Dam—local lowest } \\
\text { exposure of mud facies. }\end{array}$ & Davis Dam \\
\hline $05-40 b$ & 35.194 & -114.559 & 472.2 & 249.8 & sand & $\begin{array}{l}\text { E. side river below Davis Dam—local highest limit of } \\
\text { sand facies. }\end{array}$ & Davis Dam \\
\hline $05-40 a$ & 35.193 & -114.560 & 472.0 & 231.2 & sand/mud contact & $\begin{array}{l}\text { E. side river below Davis Dam—abrupt sand-over- } \\
\text { mud ctc. }\end{array}$ & Davis Dam \\
\hline $05-41 b$ & 35.224 & -114.567 & 474.9 & 251.2 & sand & $\begin{array}{l}\text { Katherine Landing — top of Loaf Rock near type } \\
\text { section, sand facies, rounded and angular clasts } \\
\text { concentrated as wind lag. }\end{array}$ & Davis Dam \\
\hline $05-42 a$ & 35.224 & -114.568 & 475.0 & 228.4 & sand/mud contact & $\begin{array}{l}\text { Katherine Landing-Loaf Rock, abrupt sand-over- } \\
\text { mud ctc by type section. } \\
\text { Katherine Landing-top of sand hill next to Lake }\end{array}$ & Davis Dam \\
\hline $05-43 b$ & 35.221 & -114.571 & 474.6 & 217.1 & sand & $\begin{array}{l}\text { Mohave; mostly angular clasts on top (reference } \\
\text { section). }\end{array}$ & Davis Dam \\
\hline $05-43 a$ & 35.221 & -114.570 & 474.6 & 204.0 & sand/mud contact & $\begin{array}{l}\text { Katherine Landing-sand-over-mud ctc in reference } \\
\text { section next to Lake Mohave. }\end{array}$ & Davis Dam \\
\hline $05-44 c$ & 35.223 & -114.568 & 474.9 & 199.8 & sand & $\begin{array}{l}\text { Katherine Landing-lowest local exposure of mud } \\
\text { facies on west side of Loaf Rock at unconformity on } \\
\text { megacrystic granite. }\end{array}$ & Davis Dam \\
\hline $05-45 a$ & 35.223 & -114.565 & 474.7 & 222.5 & sand/mud contact & $\begin{array}{l}\text { Katherine Landing—sand-over-mud ctc on south } \\
\text { side of Loaf Rock. }\end{array}$ & Davis Dam \\
\hline $05-45 a$ & 35.223 & -114.565 & 474.7 & 222.1 & sand/mud contact & repeat of above point. & Davis Dam \\
\hline $05-46 b$ & 34.874 & -114.527 & 432.0 & 201.7 & sand & Southpoint power plant-local highest sand. & Needles \\
\hline $05-47 b$ & 34.871 & -114.529 & 432.0 & 199.2 & sand & Southpoint power plant—local highest sand. & Needles \\
\hline
\end{tabular}


Appendix 1. Descriptions and location data for outcrops of the Chemehuevi Formation throughout the lower Colorado River Valley.-Continued

\begin{tabular}{|c|c|c|c|c|c|c|c|}
\hline Locality Index & Latitude & Longitude & $\begin{array}{l}\text { Valley } \\
\text { Distance } \\
\quad(\mathbf{k m})\end{array}$ & $\begin{array}{l}\text { Elevation }^{2} \\
\quad(\mathrm{~m})\end{array}$ & Facies & Location and Notes ${ }^{3}$ & 7.5' Quadrangle \\
\hline $05-47 a$ & 34.872 & -114.530 & 432.1 & 174.3 & sand/mud contact & $\begin{array}{l}\text { Southpoint power plant-sand-over-mud ctc below point 05- } \\
47 \mathrm{~b} \text {. }\end{array}$ & Needles \\
\hline $05-47 c$ & 34.873 & -114.530 & 432.1 & 168.5 & mud & $\begin{array}{l}\text { Southpoint power plant-mud under angular gravel below } \\
\text { point } 05-47 \mathrm{~b} \text {. }\end{array}$ & Needles \\
\hline $05-48 b$ & 34.870 & -114.531 & 431.9 & 191.9 & sand & $\begin{array}{l}\text { Southpoint power plant-top of sand facies overlooking } \\
\text { power plant. }\end{array}$ & Needles \\
\hline $05-48 a$ & 34.870 & -114.531 & 431.9 & 169.1 & sand/mud contact & $\begin{array}{l}\text { Southpoint power plant-sand-over-mud ctc below point 05- } \\
\text { 48b. }\end{array}$ & Needles \\
\hline 05-51b & 34.805 & -114.474 & 431.9 & 217.1 & sand & $\begin{array}{l}\text { Oatman highway-highest local sand on top of Bullhead } \\
\text { alluvium; rounded black chert clasts contain carbonate } \\
\text { coatings. }\end{array}$ & Warm Springs SW \\
\hline $05-51 a$ & 34.806 & -114.475 & 423.1 & 209.5 & sand/mud contact & $\begin{array}{l}\text { Oatman highway-highest local sand-over-mud ctc } \\
\text { S. of Lake Havasu City_-brown clayey mud under and }\end{array}$ & Warm Springs SW \\
\hline $05-52$ & 34.434 & -114.279 & 423.2 & 199.3 & mud & $\begin{array}{l}\text { interbedded with fan gravel; alternatively may be Bouse } \\
\text { mud. }\end{array}$ & Lake Havasu City South \\
\hline $05-54$ & 34.297 & -114.157 & 371.8 & 186.6 & mud & $\begin{array}{l}\text { Desilt Wash—high elevation bedded mud preserved below } \\
\text { low divide separating bedrock knob from Lake Havasu. } \\
\text { Bill Williams River near mouth—bedded mud under }\end{array}$ & Gene Wash \\
\hline $05-60$ & 34.287 & -114.080 & $\mathrm{n} / \mathrm{a}$ & 175.0 & tributary-Bill Williams River & $\begin{array}{l}\text { erosional unconformity below fan gravel in road cut; less } \\
\text { than } 2 \mathrm{~m} \text { are exposed. }\end{array}$ & Monkey's Head \\
\hline $05-61$ & 34.266 & -114.175 & 343.2 & 153.1 & mud & $\begin{array}{l}\text { N. of Copper Basin Wash, Calif. side of river south of Parker } \\
\text { Dam-local highest mud facies below erosional } \\
\text { unconformity. }\end{array}$ & Gene Wash \\
\hline $05-62$ & 34.266 & -114.175 & 343.2 & 138.6 & mud & $\begin{array}{l}\text { N. of Copper Basin Wash-sand-mud interbeds and local } \\
\text { gravel beds; well exposed in "natural bridges"; see figure } 8 B\end{array}$ & Gene Wash \\
\hline $05-63$ & 34.265 & -114.171 & 343.2 & 127.0 & mud & $\begin{array}{l}\text { N. of Copper Basin Wash-local lowest exposure of mud } \\
\text { facies. }\end{array}$ & Gene Wash \\
\hline $05-65 a$ & $\begin{array}{l}34.254 \\
34.254\end{array}$ & $\begin{array}{l}-114.186 \\
-114.186\end{array}$ & $\begin{array}{l}341.3 \\
341.3\end{array}$ & $\begin{array}{l}163.2 \\
177.7\end{array}$ & $\begin{array}{l}\text { sand } / \text { mud contact } \\
\text { sand }\end{array}$ & $\begin{array}{l}\text { N. of Copper Basin Wash-highest local sand-over-mud ctc. } \\
\text { N. of Copper Basin Wash-top of conical hill in sand facies. }\end{array}$ & $\begin{array}{l}\text { Gene Wash } \\
\text { Gene Wash }\end{array}$ \\
\hline $06-66$ & 34.138 & -114.227 & 328.6 & 204.6 & mud & $\begin{array}{l}\text { E. of Parker town—clayey mud inset into volcanic bedrock; } \\
\text { questionable if mud is from Chemehuevi Formation. }\end{array}$ & Cross Roads \\
\hline 05-70a & 33.686 & -114.616 & 266.3 & 106.8 & sand/mud contact & Palo Verde Mesa_-behind Blythe, local sand-over mud ctc. & Blythe NE \\
\hline
\end{tabular}


Appendix 1. Descriptions and location data for outcrops of the Chemehuevi Formation throughout the lower Colorado River Valley.-Continued [Data collected using a Trimble GeoXT handheld GPS unit while standing on outcrops and postprocessed using simultaneous data from nearby fixed base stations]

\begin{tabular}{|c|c|c|c|c|c|c|c|}
\hline Locality Index & Latitude & Longitude & $\begin{array}{c}\text { Valley } \\
\text { Distance }^{1} \\
\quad(\mathbf{k m})\end{array}$ & $\begin{array}{l}\text { Elevation }{ }^{2} \\
\quad(m)\end{array}$ & Facies & Location and Notes ${ }^{3}$ & 7.5' Quadrangle \\
\hline 05-71b & 33.686 & -114.620 & 266.1 & 123.0 & sand & $\begin{array}{l}\text { Palo Verde Mesa-behind Blythe, top of mesa on } \\
\text { sand. }\end{array}$ & Blythe NE \\
\hline 05-71a & 33.685 & -114.619 & 266.1 & 106.2 & sand/mud contact & $\begin{array}{l}\text { Palo Verde Mesa-edge of mesa, sand-over-mud } \\
\text { ctc. }\end{array}$ & Blythe NE \\
\hline $05-72 a$ & 33.691 & -114.612 & 266.9 & 108.0 & sand/mud contact & $\begin{array}{l}\text { Palo Verde Mesa-edge of mesa, sand-over-mud } \\
\text { ctc. }\end{array}$ & Blythe NE \\
\hline $05-72 a$ & 33.691 & -114.612 & 266.9 & 108.2 & sand/mud contact & repeat of above point. & Blythe NE \\
\hline $05-73$ & 33.613 & -114.705 & 255.5 & 117.4 & sand & Palo Verde Mesa-near airport, top of mesa. & Blythe NE \\
\hline $05-74$ & 33.614 & -114.745 & 254.0 & 120.6 & sand & $\begin{array}{l}\text { Palo Verde Mesa-near airport, near western limit } \\
\text { of rounded exotic gravel occurrence. }\end{array}$ & Blythe NE \\
\hline 05-77 & 33.298 & -114.761 & 224.4 & 121.5 & mud & $\begin{array}{l}\text { Near Palo Verde town-clayey mud with carbonate } \\
\text { nodules; may be Bouse Fm. }\end{array}$ & Palo Verde \\
\hline $05-79 b$ & 32.706 & -114.617 & 133.9 & 59.2 & sand & $\begin{array}{l}\text { Yuma-local highest sand facies on Yuma Mesa, at } \\
\text { Lundstrom OSL site COR-2 Yuma (est. } 44 \text { to } 56 \mathrm{ka} \text { ). }\end{array}$ & Yuma East \\
\hline 05-79a & 32.706 & -114.617 & 133.9 & 53.4 & sand/mud contact & $\begin{array}{l}\text { Yuma-sand-over mud facies Yuma Mesa above } \\
\text { Lundstrom IRSL site COR-1 Yuma (est. } 45 \text { ro } 58 \\
\text { ka). }\end{array}$ & Yuma East \\
\hline 05-81b & 32.900 & -114.491 & 161.8 & 95.1 & sand & $\begin{array}{l}\text { Senator Wash area-highest extent of rounded } \\
\text { quartzite clasts; interp'd as local highest } \\
\text { Chemehuevi. }\end{array}$ & Imperial Reservoir \\
\hline 05-81b & 32.900 & -114.491 & 161.8 & 94.5 & sand & repeat of above point. & Imperial Reservoir \\
\hline 05-82 & 32.889 & -114.491 & 158.8 & 70.0 & sand & $\begin{array}{l}\text { Senator Wash area-highest occurrence of bedded } \\
\text { C.R. sand. }\end{array}$ & Imperial Reservoir \\
\hline $05-84$ & 32.871 & -114.485 & 157.0 & 59.0 & mud & Senator Wash area—bedded C.R. mud. & Imperial Reservoir \\
\hline 05-87a & 32.510 & -114.758 & 108.8 & 37.4 & sand/mud contact & $\begin{array}{l}\text { North of San Luis Rio Colorado, at end of 22nd } \\
\text { St._-bedded mud underlying Yuma mesa. }\end{array}$ & Gasden \\
\hline 05-87b & 32.510 & -114.756 & 108.9 & 44.7 & sand & $\begin{array}{l}\text { North of San Luis Rio Colorado, at end of 22nd } \\
\text { St.-top of sand facies on mesatop. }\end{array}$ & Gasden \\
\hline 05-89a & 32.698 & -114.641 & 131.7 & 49.7 & sand/mud contact & $\begin{array}{l}\text { Yuma town—on Via Cielo Drive, abrupt sand-over- } \\
\text { mud ctc. }\end{array}$ & Yuma West \\
\hline 05-90 & 32.705 & -114.419 & 145.9 & 70.3 & mud & North of Yuma town—highest local mud facies. & Fortuna \\
\hline 05-94 & 35.833 & -114.688 & 544.9 & 261.1 & tephra & $\begin{array}{l}\text { Near Monkey Rock in Black Canyon-20 cm thick } \\
\text { ash fall tephra layer; see figure } 18 .\end{array}$ & Willow Beach \\
\hline 05-94a & 35.833 & -114.688 & 544.9 & 274.9 & mud & $\begin{array}{l}\text { Near Monkey Rock in Black Canyon—local highest } \\
\text { mud facies. }\end{array}$ & Willow Beach \\
\hline 05-94c & 35.833 & -114.689 & 544.9 & 249.4 & mud & $\begin{array}{l}\text { Near Monkey Rock in Black Canyon—local lowest } \\
\text { mud facies. }\end{array}$ & Willow Beach \\
\hline
\end{tabular}




\begin{tabular}{|c|c|c|c|c|c|c|c|}
\hline Locality Index & Latitude & Longitude & $\begin{array}{c}\text { Valley } \\
\text { Distance }^{1} \\
\quad(\mathbf{k m})\end{array}$ & $\begin{array}{l}\text { Elevation } \\
\quad(m)\end{array}$ & Facies & Location and Notes $^{3}$ & Quadrangle \\
\hline $05-96 b$ & 35.719 & -114.697 & 531.9 & 240.2 & sand & $\begin{array}{l}\text { Elephant Hill paleovalley - top of sand facies hill at entrance } \\
\text { to paleovalley, next to Lake Mohave. }\end{array}$ & Fire Mountain \\
\hline $05-96 a$ & 35.719 & -114.696 & 531.8 & 217.5 & sand/mud contact & $\begin{array}{l}\text { Elephant Hill paleovalley-sand-over-mud contact on south } \\
\text { side of otc at the entrance to paleovalley. }\end{array}$ & Fire Mountain \\
\hline $05-96 a$ & 35.719 & -114.696 & 531.8 & 217.3 & sand/mud contact & repeat of above point. & Fire Mountain \\
\hline $05-96 \mathrm{c}$ & 35.719 & -114.698 & 531.8 & 200.0 & mud & $\begin{array}{l}\text { Elephant Hill paleovalley-lowest exposure of mud facies } \\
\text { next to Lake Mohave, at entrance to paleovalley. }\end{array}$ & Fire Mountain \\
\hline $05-97$ & 35.713 & -114.685 & 530.9 & 282.0 & sand & $\begin{array}{l}\text { Elephant Hill paleovalley_top of sand hill in center of } \\
\text { paleovalley. }\end{array}$ & Fire Mountain \\
\hline $05-99$ & 35.712 & -114.685 & 530.8 & 260.7 & sand/mud contact & $\begin{array}{l}\text { Elephant Hill paleovalley-layered mud below sand at site } \\
\text { 05-97, in center of paleovalley. }\end{array}$ & Fire Mountain \\
\hline $05-100 b$ & 35.715 & -114.678 & 531.0 & 300.8 & sand & $\begin{array}{l}\text { Elephant Hill paleovalley-highest occurrence of rounded } \\
\text { exotic pebbles in sand overlying layered mud. }\end{array}$ & Fire Mountain \\
\hline $05-100 \mathrm{a}$ & 35.715 & -114.678 & 531.0 & 296.9 & mud & $\begin{array}{l}\text { Elephant Hill paleovalley-highest elevation layered mud in } \\
\text { paleovalley. }\end{array}$ & Fire Mountain \\
\hline 05-100OSL & 35.715 & -114.678 & 531.0 & 295.9 & mud & $\begin{array}{l}\text { Elephant Hill paleovalley-high elevation layered mud in } \\
\text { paleovalley; sampled for OSL. }\end{array}$ & Fire Mountain \\
\hline $05-113 a$ & 35.746 & -114.719 & 534.8 & 308.2 & mud & $\begin{array}{l}\text { N. of Nelson-highest layered mud under fan gravel, isolated } \\
\text { from main outcrops. }\end{array}$ & Fire Mountain \\
\hline $05-114$ & 35.744 & -114.713 & 534.7 & 275.5 & mud & $\begin{array}{l}\text { N. of Nelson-layered clay deposit in middle outcrop; beds } \\
\text { dip 5-8 degrees to the east (towards river); see figure } 10 D \text {. }\end{array}$ & Fire Mountain \\
\hline $05-115$ & 35.745 & -114.713 & 534.7 & 278.4 & mud & N. of Nelson—silty sand in middle otc. & Fire Mountain \\
\hline $05-117$ & 35.745 & -114.713 & 534.7 & 284.3 & mud & $\begin{array}{l}\text { N. of Nelson-within mud facies at contact between silty } \\
\text { sand (below) and clay (above). }\end{array}$ & Fire Mountain \\
\hline $05-116$ & 35.745 & -114.713 & 534.7 & 287.1 & sand/mud contact & N. of Nelson—sand over mud contact just above $05-117$. & Fire Mountain \\
\hline $05-118$ & 35.744 & -114.712 & 534.6 & 277.4 & mud & N. of Nelson-internal contact in mud facies. & Fire Mountain \\
\hline $05-119$ & 35.745 & -114.713 & 534.7 & 277.6 & mud & N. of Nelson-internal contact in mud facies. & Fire Mountain \\
\hline $05-120$ & 35.745 & -114.713 & 534.7 & 282.8 & mud & $\begin{array}{l}\text { N. of Nelson-internal contact in mud facies - near } \\
\text { radiocarbon date of Blair (1996). }\end{array}$ & Fire Mountain \\
\hline $05-121$ & 35.745 & -114.713 & 534.7 & 290.3 & sand & N. of Nelson-local highest sand facies. & Fire Mountain \\
\hline $05-123$ & 35.745 & -114.713 & 534.7 & 276.1 & mud & N. of Nelson-internal contact in mud facies. & Fire Mountain \\
\hline $05-124$ & 35.744 & -114.711 & 534.6 & 265.5 & mud & N. of Nelson-local highest mud facies. & Fire Mountain \\
\hline $05-125$ & 35.744 & -114.711 & 534.6 & 266.7 & mud & N. of Nelson-internal contact in mud facies. & Fire Mountain \\
\hline $05-126$ & 35.744 & -114.711 & 534.6 & 267.9 & mud & N. of Nelson-internal contact in mud facies. & Fire Mountain \\
\hline $05-126$ & 35.744 & -114.711 & 534.6 & 268.3 & mud & N. of Nelson-internal contact in mud facies. & Fire Mountain \\
\hline
\end{tabular}


Appendix 1. Descriptions and location data for outcrops of the Chemehuevi Formation throughout the lower Colorado River Valley.-Continued

[Data collected using a Trimble GeoXT handheld GPS unit while standing on outcrops and postprocessed using simultaneous data from nearby fixed base stations]

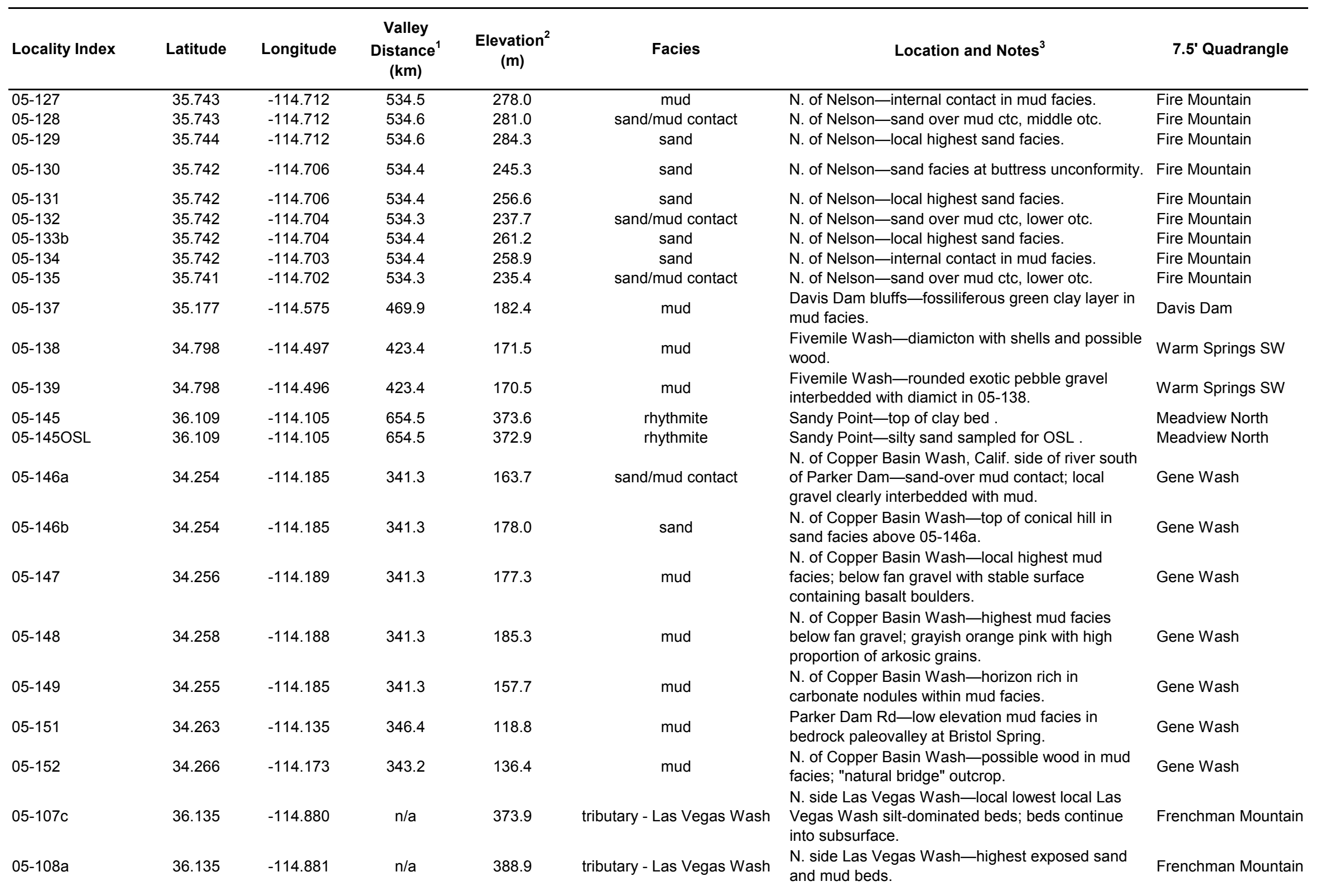


Appendix 1. Descriptions and location data for outcrops of the Chemehuevi Formation throughout the lower Colorado River Valley.-Continued

[Data collected using a Trimble GeoXT handheld GPS unit while standing on outcrops and postprocessed using simultaneous data from nearby fixed base stations]

\begin{tabular}{|c|c|c|c|c|c|c|c|}
\hline Locality Index & Latitude & Longitude & $\begin{array}{l}\text { Valley } \\
\text { Distance }^{1} \\
\quad(\mathbf{k m})\end{array}$ & $\begin{array}{l}\text { Elevation } \\
\quad(m)\end{array}$ & Facies & Location and Notes ${ }^{3}$ & 7.5' Quadrangle \\
\hline 05-199 & 35.353 & -114.583 & 489.3 & 261.6 & mud & $\begin{array}{l}\text { Lost Cabin Wash—highest local mud facies } \\
\text { preserved in paleovalley cut into old gravel; } \\
\text { underlies fan. }\end{array}$ & Spirit Mtn SE \\
\hline 05-94OSL & 35.833 & -114.688 & 544.9 & 259.9 & mud & $\begin{array}{l}\text { Monkey Rock tephra site-OSL sample collected } \\
\text { here } 0.6 \mathrm{~m} \text { below tephra bed. }\end{array}$ & Willow Beach \\
\hline 05-94' & 35.833 & -114.688 & 544.9 & 260.4 & mud & repeat of above point. & Willow Beach \\
\hline $05-209$ & 36.483 & -114.331 & $\mathrm{n} / \mathrm{a}$ & 380.9 & tributary - Virgin River & $\begin{array}{l}\text { Virgin River Narrows paleovalley_fining upwards } \\
\text { beds of mud and sand near inlet of paleovalley; } \\
\text { underlies fan gravel. }\end{array}$ & Overton Beach \\
\hline $05-210$ & 36.482 & -114.332 & $\mathrm{n} / \mathrm{a}$ & 369.3 & tributary - Virgin River & $\begin{array}{l}\text { Virgin River Narrows paleovalley_local lowest } \\
\text { exposed mud beds. }\end{array}$ & Overton Beach \\
\hline $05-215$ & 36.478 & -114.326 & $\mathrm{n} / \mathrm{a}$ & 399.1 & tributary - Virgin River & $\begin{array}{l}\text { Virgin River Narrows paleovalley-highest local } \\
\text { sand containing scattered angular and rounded } \\
\text { gravel; center of paleovalley. }\end{array}$ & Overton Beach \\
\hline $05-216$ & 36.478 & -114.328 & $\mathrm{n} / \mathrm{a}$ & 394.6 & tributary - Virgin River & $\begin{array}{l}\text { Virgin River Narrows paleovalley-highest local } \\
\text { sand in buttress unconformity with old gravel edge } \\
\text { of paleovalley. }\end{array}$ & Overton Beach \\
\hline 05-216 OSL & 36.478 & -114.328 & $\mathrm{n} / \mathrm{a}$ & 390.8 & tributary - Virgin River & $\begin{array}{l}\text { Virgin River Narrows paleovalley-very fine sand } \\
\text { with mud lenses; underlies fan gravel; sampled for } \\
\text { OSL. }\end{array}$ & Overton Beach \\
\hline $05-222 d$ & 36.703 & -114.242 & $\mathrm{n} / \mathrm{a}$ & 461.7 & tributary - Virgin River & $\begin{array}{l}\text { Riverside Rd south of Mesquite, Nev.- - lowest } \\
\text { bedded sand and mud in roadcut exposure. }\end{array}$ & Riverside \\
\hline 05-222c OSL & 36.703 & -114.241 & $\mathrm{n} / \mathrm{a}$ & 468.3 & tributary - Virgin River & $\begin{array}{l}\text { Riverside Rd south of Mesquite, Nev.-Virgin River } \\
\text { sand in roadcut; sampled for OSL approx. } 2 \mathrm{~m} \\
\text { below unconformity with overlying fan gravel. }\end{array}$ & Riverside \\
\hline 06-301 & 36.098 & -114.093 & 653.7 & 394.6 & rhythmite & South Cove outcrops-local highest bedded mud. & Meadview North \\
\hline 06-301a & 36.098 & -114.093 & 653.7 & 390.0 & rhythmite & $\begin{array}{l}\text { South Cove outcrops-lighter colored layer below } \\
06-301 .\end{array}$ & Meadview North \\
\hline $06-303 b$ & 36.098 & -114.092 & 653.8 & 390.2 & rhythmite & $\begin{array}{l}\text { South Cove outcrops-grayish green clay layer in } \\
\text { figure } 13 D \text {. }\end{array}$ & Meadview North \\
\hline 06-303a & 36.098 & -114.092 & 653.8 & 394.0 & rhythmite & South Cove outcrops-local highest massive sand. & Meadview North \\
\hline $06-304$ & 36.098 & -114.093 & 653.8 & 374.6 & rhythmite & $\begin{array}{l}\text { South Cove outcrops-base of } 6-\mathrm{m} \text { thick } \\
\text { rhythmically bedded exposure in figure } 13 C \text {. }\end{array}$ & Meadview North \\
\hline 06-305 OSL & 36.097 & -114.092 & 653.7 & 393.6 & rhythmite & $\begin{array}{l}\text { South Cove outcrops-highest sand bed in section } \\
\text { continuous with the one in figure } 13 C \text {; sampled here } \\
\text { for OSL }\end{array}$ & Meadview North \\
\hline
\end{tabular}


Appendix 1. Descriptions and location data for outcrops of the Chemehuevi Formation throughout the lower Colorado River Valley.-Continued

[Data collected using a Trimble GeoXT handheld GPS unit while standing on outcrops and postprocessed using simultaneous data from nearby fixed base stations]

\begin{tabular}{|c|c|c|c|c|c|c|c|}
\hline Locality Index & Latitude & Longitude & $\begin{array}{l}\text { Valley } \\
\text { Distance }^{1} \\
(\mathrm{~km})\end{array}$ & $\begin{array}{l}\text { Elevation }{ }^{2} \\
\quad(m)\end{array}$ & Facies & Location and Notes ${ }^{3}$ & 7.5' Quadrangle \\
\hline 06-322 & 34.838 & -114.613 & 432.7 & 167.9 & valley-margin & $\begin{array}{l}\text { Downtown Needles, Calif.—poorly bedded pink } \\
\text { sediments across the street from Denny's. }\end{array}$ & Needles \\
\hline 06-323a & 34.735 & -114.476 & 416.5 & 163.0 & sand/mud contact & $\begin{array}{l}\text { Near mouth of Sacramento Wash—mud balls in } \\
\text { sand. }\end{array}$ & Topock \\
\hline 06-324 & 34.738 & -114.475 & $\mathrm{n} / \mathrm{a}$ & 158.1 & tributary & $\begin{array}{l}\text { Sacramento Wash—gypsum rich, blueish clay beds } \\
\text { with abundant plant remains; freshwater snail shell } \\
\text { collected here. }\end{array}$ & Topock \\
\hline 06-325 & 34.839 & -114.500 & 427.4 & 191.4 & mud & $\begin{array}{l}\text { E. of Topock Marsh-lowest local bedded mud } \\
\text { overlying river gravel; mud may be conformable with } \\
\text { underlying gravel. }\end{array}$ & Warm Springs SW \\
\hline $06-325 a$ & 34.839 & -114.499 & 427.4 & 209.3 & sand/mud contact & $\begin{array}{l}\text { E. of Topock Marsh-abrupt sand-over-mud } \\
\text { contact. }\end{array}$ & Warm Springs SW \\
\hline $06-325 b$ & 34.839 & -114.499 & 427.4 & 219.8 & sand & E. of Topock Marsh—highest local sand facies. & Warm Springs SW \\
\hline $06-428-1$ & 35.742 & -114.706 & 534.4 & 244.8 & sand/mud contact & $\begin{array}{l}\text { N. of Nelson-abrupt sand-over-mud contact in } \\
\text { lower section. }\end{array}$ & Fire Mountain \\
\hline $06-428-2$ & 35.742 & -114.705 & 534.4 & 258.7 & sand & N. of Nelson-highest sand facies above $06-428-1$. & Fire Mountain \\
\hline $06-428-3$ & 35.742 & -114.699 & 534.4 & 238.8 & sand & $\begin{array}{l}\text { N. of Nelson-Top of steep sand mound next to } \\
\text { Lake Mohave. }\end{array}$ & Fire Mountain \\
\hline $06-428-4$ & 35.742 & -114.699 & 534.4 & 215.6 & sand & $\begin{array}{l}\text { N. of Nelson-Sand facies exposure near Lake } \\
\text { Mohave. }\end{array}$ & Fire Mountain \\
\hline 06-429-1 OSL & 35.744 & -114.711 & 534.6 & 267.4 & mud & $\begin{array}{l}\text { N. of Nelson-Sand bed near bottom of upper } \\
\text { exposure containing wood fragments; sampled for } \\
\text { OSL. }\end{array}$ & Fire Mountain \\
\hline $06-429-1-0$ & 35.744 & -114.711 & 534.6 & 265.8 & mud & N. of Nelson-local base of exposure in stream bed. & Fire Mountain \\
\hline $06-429-1-5$ & 35.744 & -114.712 & 534.6 & 283.6 & sand & N. of Nelson—sand facies. & Fire Mountain \\
\hline $06-429-1-3$ & 35.744 & -114.712 & 534.6 & 279.1 & mud & N. of Nelson—bedded mud facies. & Fire Mountain \\
\hline $06-429-1-4$ & 35.744 & -114.712 & 534.6 & 280.2 & sand/mud contact & $\begin{array}{l}\text { N. of Nelson-sand over mud contact in middle } \\
\text { outcrop. }\end{array}$ & Fire Mountain \\
\hline $06-429-2$ & 35.744 & -114.713 & 534.7 & 278.8 & mud & N. of Nelson-internal contact in mud facies. & Fire Mountain \\
\hline 06-429-3a OSL & 35.746 & -114.719 & 534.8 & 309.1 & sand & $\begin{array}{l}\text { N. of Nelson-isolated otc under fan; sampled for } \\
\text { OSL. }\end{array}$ & Fire Mountain \\
\hline $06-429-3$ & 35.746 & -114.719 & 534.8 & 306.3 & sand/mud contact & $\begin{array}{l}\text { N. of Nelson-isolated otc under fan; local highest } \\
\text { sand. }\end{array}$ & Fire Mountain \\
\hline 06-430-1OSL & 35.742 & -114.699 & 534.4 & 215.9 & sand & $\begin{array}{l}\text { N. of Nelson-ripple bedded sand bed next to Lake } \\
\text { Mohave; sampled for OSL. }\end{array}$ & Fire Mountain \\
\hline
\end{tabular}


[Data collected using a Trimble GeoXT handheld GPS unit while standing on outcrops and postprocessed using simultaneous data from nearby fixed base stations]

\begin{tabular}{|c|c|c|c|c|c|c|c|}
\hline Locality Index & Latitude & Longitude & $\begin{array}{l}\text { Valley } \\
\text { Distance }^{1} \\
\quad(\mathbf{k m})\end{array}$ & $\begin{array}{l}\text { Elevation } \\
\quad(m)\end{array}$ & Facies & Location and Notes ${ }^{3}$ & 7.5' Quadrangle \\
\hline $06-430-4$ & 35.742 & -114.705 & 534.4 & 246.2 & sand/mud contact & $\begin{array}{l}\text { N. of Nelson-sand-over-mud erosional contact in } \\
\text { middle outcrop. }\end{array}$ & Fire Mountain \\
\hline 06-430-3 OSL & 35.742 & -114.705 & 534.4 & 249.0 & sand & $\begin{array}{l}\text { N. of Nelson-sand in middle outcrop, above } \\
\text { unconformity; sampled for OSL. }\end{array}$ & Fire Mountain \\
\hline 06-430-4 OSL & 35.742 & -114.705 & 534.4 & 242.1 & mud & $\begin{array}{l}\text { N. of Nelson-silty bed in mud facies middle } \\
\text { outcrop, below unconformity; sampled for OSL. }\end{array}$ & Fire Mountain \\
\hline $06-430-7$ & 35.745 & -114.713 & 534.7 & 283.7 & mud & $\begin{array}{l}\text { N. of Nelson-internal contact in mud facies, } \\
\text { western part of upper outcrop. }\end{array}$ & Fire Mountain \\
\hline $06-430-8$ & 35.745 & -114.713 & 534.7 & 287.7 & sand/mud contact & $\begin{array}{l}\text { N. of Nelson-sand-over-mud erosional contact, } \\
\text { western part of upper outcrop. }\end{array}$ & Fire Mountain \\
\hline $06-430-9$ & 35.745 & -114.713 & 534.7 & 289.6 & sand & N. of Nelson—local highest sand facies. & Fire Mountain \\
\hline 06-430-11 OSL & 35.745 & -114.713 & 534.7 & 279.3 & mud & $\begin{array}{l}\text { N. of Nelson-silty sand bed in middle outcrop; } \\
\text { sampled for OSL. }\end{array}$ & Fire Mountain \\
\hline $06-501-1$ & 35.720 & -114.698 & 532.0 & 215.7 & sand/mud contact & $\begin{array}{l}\text { Elephant Hill paleovalley-sand-over-mud contact } \\
\text { near Lake Mohave shown in figure } 1 .\end{array}$ & Fire Mountain \\
\hline $06-501-2$ & 35.719 & -114.696 & 531.8 & 217.4 & sand/mud contact & $\begin{array}{l}\text { Elephant Hill paleovalley-sand-over-mud contact } \\
\text { near Lake Mohave; continous with contact at 06-501. } \\
1 .\end{array}$ & - Fire Mountain \\
\hline $06-501-3$ & 35.719 & -114.697 & 531.8 & 197.7 & mud & $\begin{array}{l}\text { Elephant Hill paleovalley-lowest exposure of mud } \\
\text { facies in figure } 1 .\end{array}$ & Fire Mountain \\
\hline 06-501-4 OSL & 35.719 & -114.697 & 531.8 & 200.3 & mud & $\begin{array}{l}\text { Elephant Hill paleovalley-fine sand bed in mud } \\
\text { facies near Lake Mohave in figure 1; sampled for } \\
\text { OSL. }\end{array}$ & Fire Mountain \\
\hline 06-501-5 OSL & 35.719 & -114.697 & 531.9 & 223.5 & sand & $\begin{array}{l}\text { Elephant Hill paleovalley_planar bedded sand } \\
\text { above erosional contact near Lake Mohave in figure } \\
\text { 1; sampled for OSL. }\end{array}$ & Fire Mountain \\
\hline 06-1103-1 & 33.682 & -114.465 & 271.7 & 118.7 & sand/mud contact & $\begin{array}{l}\text { N. side La Paz Wash, north of Ehrenberg tusk } \\
\text { locality—sand-over-mud contact. }\end{array}$ & La Paz Mountain \\
\hline 06-1103-2 & 33.679 & -114.457 & 271.7 & 130.7 & sand & N. of Ehrenberg—local highest sand facies. & La Paz Mountain \\
\hline 06-1104-3 & 33.375 & -114.639 & 233.9 & 112.1 & sand & $\begin{array}{l}\text { Cibola area-sand inset into scarp; may be related } \\
\text { to terrace gravel. }\end{array}$ & Cibola \\
\hline 06-1104-4 & 33.381 & -114.635 & 234.7 & 109.8 & sand & Cibola area-sand inset into scarp n. of 06-1104-3. & Cibola \\
\hline $06-1104-5$ & 33.373 & -114.639 & 233.8 & 111.6 & mud & Cibola area—carbonate-rich mud bed & Cibola \\
\hline 06-1104-6 & 33.501 & -114.752 & 242.3 & 98.1 & sand & $\begin{array}{l}\text { W. of Palo Verde town-carbonate-rich cross } \\
\text { bedded sand in exposure in Palo Verde Mesa. }\end{array}$ & Palo Verde \\
\hline 06-1104-7 & 33.491 & -114.745 & 241.7 & 89.8 & mud & $\begin{array}{l}\text { W. of Palo Verde town-highest mud under fan; } \\
\text { mud overlies sand facies locally. }\end{array}$ & Palo Verde \\
\hline $06-1105-1$ & 33.623 & -114.493 & 264.7 & 109.2 & sand/mud contact & $\begin{array}{l}\text { N. of Ehrenberg-sand-over-mud contact near } \\
\text { chicken houses. }\end{array}$ & La Paz Mountain \\
\hline
\end{tabular}


Appendix 1. Descriptions and location data for outcrops of the Chemehuevi Formation throughout the lower Colorado River Valley.-Continued

[Data collected using a Trimble GeoXT handheld GPS unit while standing on outcrops and postprocessed using simultaneous data from nearby fixed base stations]

\begin{tabular}{|c|c|c|c|c|c|c|c|}
\hline Locality Index & Latitude & Longitude & $\begin{array}{l}\text { Valley } \\
\text { Distance }^{1} \\
\quad(\mathbf{k m})\end{array}$ & $\begin{array}{l}\text { Elevation }^{2} \\
\quad(\mathrm{~m})\end{array}$ & Facies & Location and Notes ${ }^{3}$ & 7.5' Quadrangle \\
\hline $06-1105-2$ & 33.664 & -114.477 & 269.5 & 110.4 & mud & $\begin{array}{l}\text { N. of Ehrenberg tusk locality-wood branch in mud; } \\
\text { turned out to be young ( } 350 \text { yr old) wood. }\end{array}$ & La Paz Mountain \\
\hline $06-1105-4$ & 33.662 & -114.475 & 269.3 & 114.9 & sand/mud contact & $\begin{array}{l}\text { N. of Ehrenberg tusk locality-abrupt sand-over- } \\
\text { mud contact. }\end{array}$ & La Paz Mountain \\
\hline $06-1105-5$ & 33.659 & -114.465 & 269.4 & 131.1 & mud & N. of Ehrenberg tusk locality—mud facies. & La Paz Mountain \\
\hline 06-1105-6 & 33.659 & -114.460 & 269.5 & 137.7 & mud & $\begin{array}{l}\text { N. of Ehrenberg tusk locality-highest local mud } \\
\text { facies under fan gravel. }\end{array}$ & La Paz Mountain \\
\hline 06-1106-1 & 34.075 & -114.261 & 321.2 & 155.2 & sand/mud contact & $\begin{array}{l}\text { SE of Parker town-high-elevation sand-mud } \\
\text { contact; near well LCRP-21. }\end{array}$ & Parker SE \\
\hline $06-1106-1 b$ & 34.075 & -114.260 & 321.2 & 160.2 & sand & SE of Parker town-local highest sand facies. & Parker SE \\
\hline 06-1106-3-1 & 34.184 & -114.246 & 331.4 & 114.4 & mud & $\begin{array}{l}\text { Parker Dam Rd-local lowest exposure mud facies } \\
\text { north of C.R. }\end{array}$ & Cross Roads \\
\hline 06-1106-3-2 & 34.184 & -114.247 & 331.4 & 127.6 & sand/mud contact & $\begin{array}{l}\text { Parker Dam Rd-sand-over-mud outcrop north of } \\
\text { C.R. }\end{array}$ & Cross Roads \\
\hline 06-1106-3-3 & 34.185 & -114.248 & 331.5 & 151.1 & sand & Parker Dam Rd—top of sand hill north of river. & Cross Roads \\
\hline 06-1106-4OSL & 34.256 & -114.187 & 341.3 & 171.3 & sand & $\begin{array}{l}\text { N. of Copper Basin Wash-ripple crossbedded } \\
\text { sand; GPS location of OSL sample 05-227. }\end{array}$ & Gene Wash \\
\hline $06-1106-5$ & 34.256 & -114.186 & 341.3 & 155.7 & mud & $\begin{array}{l}\text { N. of Copper Basin Wash—carbonate horizon in } \\
\text { mud facies. }\end{array}$ & Gene Wash \\
\hline 06-1106-6OSL & 34.254 & -114.185 & 341.3 & 141.8 & mud & $\begin{array}{l}\text { N. of Copper Basin Wash-silty sand bed near base } \\
\text { of outcrop below sand-over-mud contact below 05- } \\
227 \text {; GPS location of OSL sample 05-228. }\end{array}$ & Gene Wash \\
\hline $06-1107-1$ & 35.312 & -114.586 & 484.8 & 217.9 & tephra & Desert Cove, Lake Mohave_tephra layer. & Spirit Mountain SE \\
\hline 06-1107-2 & 35.314 & -114.585 & 485.0 & 233.2 & mud & $\begin{array}{l}\text { Desert Cove, Lake Mohave-fossilized logs in float; } \\
\text { some fragments contain silica-rich core. }\end{array}$ & Spirit Mountain SE \\
\hline $06-1107-3$ & 35.315 & -114.585 & 485.1 & 242.4 & mud & $\begin{array}{l}\text { Desert Cove, Lake Mohave-local lowest mud } \\
\text { facies exposure. }\end{array}$ & Spirit Mountain SE \\
\hline $06-1107-4$ & 35.312 & -114.586 & 484.8 & 218.1 & tephra & Desert Cove, Lake Mohave_tephra layer. & Spirit Mountain SE \\
\hline $06-1107-5$ & 35.312 & -114.586 & 484.8 & 218.9 & tephra & Desert Cove, Lake Mohave-tephra layer. & Spirit Mountain SE \\
\hline 06-1107-6 & 35.312 & -114.586 & 484.8 & 216.8 & tephra & Desert Cove, Lake Mohave_tephra layer. & Spirit Mountain SE \\
\hline $06-1107-7$ & 35.312 & -114.586 & 484.8 & 213.9 & mud & $\begin{array}{l}\text { Desert Cove, Lake Mohave-local lowest mud } \\
\text { facies exposure. }\end{array}$ & Spirit Mountain SE \\
\hline 06-1107-9 & 35.242 & -114.568 & 476.9 & 241.0 & sand/mud contact & $\begin{array}{l}\text { Cabinsite, N. of Katherine-abrupt sand-over-mud } \\
\text { ctc. }\end{array}$ & Davis Dam \\
\hline 06-1107-10 & 35.242 & -114.568 & 476.9 & 259.5 & sand & $\begin{array}{l}\text { Cabinsite, N. of Katherine-local highest sand; } \\
\text { stage II carbonate soil on sand. }\end{array}$ & Davis Dam \\
\hline 06-1107-11 & 35.241 & -114.567 & 476.8 & 220.8 & mud & Cabinsite, N. of Katherine-local lowest mud facies. & Davis Dam \\
\hline
\end{tabular}


[Data collected using a Trimble GeoXT handheld GPS unit while standing on outcrops and postprocessed using simultaneous data from nearby fixed base stations]

\begin{tabular}{|c|c|c|c|c|c|c|c|}
\hline Locality Index & Latitude & Longitude & $\begin{array}{l}\text { Valley } \\
\text { Distance } \\
\quad(\mathbf{k m})\end{array}$ & $\begin{array}{l}\text { Elevation }^{2} \\
\quad(\mathrm{~m})\end{array}$ & Facies & Location and Notes ${ }^{3}$ & 7.5' Quadrangle \\
\hline$\overline{06-1107-12}$ & 35.223 & -114.565 & 474.7 & 210.1 & tephra & Katherine Landing $-0.5 \mathrm{~m}$ thick tephra bed. & Davis Dam \\
\hline $06-1108-4 b$ & 34.866 & -114.504 & 430.2 & 220.4 & sand & $\begin{array}{l}\text { NE corner Needles quadrangle-local highest sand } \\
\text { facies. }\end{array}$ & Needles \\
\hline $06-1108-4 a$ & 34.865 & -114.504 & 430.1 & 211.1 & sand/mud contact & $\begin{array}{l}\text { NE corner Needles quadrangle-abrupt sand-over- } \\
\text { mud contact. }\end{array}$ & Needles \\
\hline $06-1218-1$ & 34.744 & -114.464 & $\mathrm{n} / \mathrm{a}$ & 160.4 & tributary - Sacramento Wash & $\begin{array}{l}\text { Sacramento Wash—silicified sand below marker } \\
\text { horizon that is traceable to folded layers. } \\
\text { Willow Road, quarry site_clay containing }\end{array}$ & Topock \\
\hline $06-1221-1$ & 34.705 & -114.450 & 413.0 & 215.7 & valley-margin & $\begin{array}{l}\text { ostracodes on top of soil-mantled erosional } \\
\text { unconformity within Colorado R. sediments. }\end{array}$ & Needles NE \\
\hline $06-1221-2$ & 34.905 & -114.525 & 434.9 & 202.2 & mud & $\begin{array}{l}\text { Southpoint powerplant outcrop-carbonate horizon } \\
\text { in lowest mud facies; mapped as Needles beds by } \\
\text { Malmon and others (2009a). }\end{array}$ & Needles \\
\hline $06-1221-3$ & 34.872 & -114.533 & 432.2 & 162.0 & mud & $\begin{array}{l}\text { W.-facing outcrop near powerplant-mud facies } \\
\text { over soil-mantled erosional unconformity within } \\
\text { Colorado R. sediments. }\end{array}$ & Needles \\
\hline $06-1221-4$ & 34.875 & -114.533 & 432.5 & 166.2 & mud & $\begin{array}{l}\text { N. of powerplant outcrop-mud over soil-mantled } \\
\text { unconformity. }\end{array}$ & Needles \\
\hline $06-1222-2$ & 34.857 & -114.514 & 429.9 & 174.9 & tephra & $\begin{array}{l}\text { S. of powerplant-reworked tephra bed as basal } \\
\text { layer of mud facies. }\end{array}$ & Needles \\
\hline $07-422-1$ & 35.353 & -114.591 & 489.4 & 226.8 & mud & $\begin{array}{l}\text { Lost Cabin Wash—low in local mud facies nr Lake } \\
\text { Mohave. }\end{array}$ & Spirit Mountain NW \\
\hline $07-423-6$ & 34.566 & -114.394 & 393.0 & 139.4 & mud & Castle Rock—carbonate rich bed in mud facies. & Castle Rock \\
\hline $07-424-1$ & 35.224 & -114.569 & 475.0 & 228.1 & sand/mud contact & $\begin{array}{l}\text { Katherine Landing-cemented bed at sand-over- } \\
\text { mud ctc below interlayered sand and mud. }\end{array}$ & Davis Dam \\
\hline $07-424-3$ & 35.227 & -114.577 & 475.4 & 211.9 & sand/mud contact & $\begin{array}{l}\text { Katherine Landing-sand-over-mud ctc nr Lake } \\
\text { Mohave. }\end{array}$ & Davis Dam \\
\hline $07-424-4$ & 35.221 & -114.571 & 474.6 & 215.8 & sand & $\begin{array}{l}\text { Katherine Landing-local highest sand facies on } \\
\text { conical hill next to Lake Mohave; top of reference } \\
\text { section (fig. 26A). }\end{array}$ & Davis Dam \\
\hline $07-424-6$ & 35.223 & -114.565 & 474.7 & 211.8 & tephra & $\begin{array}{l}\text { Katherine Landing-resurvey of tephra layer in type } \\
\text { section (table 9). }\end{array}$ & Davis Dam \\
\hline $07-424-7$ & 35.222 & -114.565 & 474.7 & 203.0 & mud & $\begin{array}{l}\text { Katherine Landing-base of measured type section } \\
\text { (table 9). }\end{array}$ & Davis Dam \\
\hline $07-425-1$ & 35.223 & -114.565 & 474.7 & 222.3 & sand/mud contact & $\begin{array}{l}\text { Katherine Landing-sand-over-mud contact in type } \\
\text { section (table 9). }\end{array}$ & Davis Dam \\
\hline $07-425-2$ & 35.224 & -114.566 & 474.8 & 250.0 & sand & $\begin{array}{l}\text { Katherine Landing-top of measured type section } \\
\text { (table 9). }\end{array}$ & Davis Dam \\
\hline
\end{tabular}


Appendix 1. Descriptions and location data for outcrops of the Chemehuevi Formation throughout the lower Colorado River Valley.-Continued

[Data collected using a Trimble GeoXT handheld GPS unit while standing on outcrops and postprocessed using simultaneous data from nearby fixed base stations]

\begin{tabular}{|c|c|c|c|c|c|c|c|}
\hline Locality Index & Latitude & Longitude & $\begin{array}{c}\text { Valley } \\
\text { Distance }^{1} \\
(\mathbf{k m})\end{array}$ & $\begin{array}{l}\text { Elevation }^{2} \\
\quad(\mathrm{~m})\end{array}$ & Facies & Location and Notes $^{3}$ & 7.5' Quadrangle \\
\hline $07-425-3$ & 35.223 & -114.566 & 474.8 & 247.7 & sand & $\begin{array}{l}\text { Katherine Landing-slope break within sand facies; } \\
\text { measured type section (table } 9 \text { ). }\end{array}$ & Davis Dam \\
\hline $07-425-4$ & 35.223 & -114.565 & 474.8 & 226.0 & sand & $\begin{array}{l}\text { Katherine Landing-top of angular gravel interval } \\
\text { within sand facies; measured type section (table 9). }\end{array}$ & Davis Dam \\
\hline $07-425-5$ & 35.223 & -114.565 & 474.7 & 211.3 & tephra & $\begin{array}{l}\text { Katherine Landing-resurvey of tephra layer in type } \\
\text { section (table 9). }\end{array}$ & Davis Dam \\
\hline $07-425-6$ & 35.222 & -114.565 & 474.7 & 204.2 & mud & $\begin{array}{l}\text { Katherine Landing-top of gravel interval near base } \\
\text { of type section within mud facies (table } 9 \text { ). }\end{array}$ & Davis Dam \\
\hline $07-425-7$ & 35.222 & -114.565 & 474.7 & 201.5 & mud & $\begin{array}{l}\text { Katherine Landing-resurvey base of measured } \\
\text { type section (table } 9 \text { ). }\end{array}$ & Davis Dam \\
\hline $07-508-1$ & 34.836 & -114.507 & 427.5 & 172.7 & mud & $\begin{array}{l}\text { S. of Ft. Mojave power plant-at mud contact over } \\
\text { boulder-rich piedmont gravel; pictured in figure } 14 \text { of } \\
\text { Metzger and Loeltz (1973). }\end{array}$ & Needles \\
\hline $07-508-2$ & 34.839 & -114.508 & 427.8 & 168.2 & mud & $\begin{array}{l}\text { S. of Ft. Mojave power plant-mud beds dipping } 5 \\
\text { degrees to the east. }\end{array}$ & Needles \\
\hline 07-508-3 & 34.837 & -114.507 & 427.7 & 168.7 & mud & S. of power plant- layered mud. & Needles \\
\hline $07-508-4$ & 34.836 & -114.508 & 427.6 & 162.4 & mud & S. of power plant-unconformity in layered mud. & Needles \\
\hline $07-511-6$ & 34.764 & -114.591 & 424.7 & 222.4 & sand & $\begin{array}{l}\text { Route } 66 \text { south of Needles-sand at point where it } \\
\text { is inset into scarp in piedmont gravel. }\end{array}$ & Needles \\
\hline $07-511-8$ & 34.760 & -114.586 & 424.0 & 223.1 & sand & $\begin{array}{l}\text { Route } 66 \text { south of Needles-sand at point where it } \\
\text { is inset into scarp in piedmont gravel. }\end{array}$ & Needles \\
\hline $07-511-9$ & 34.778 & -114.601 & 426.5 & 230.4 & sand & $\begin{array}{l}\text { Route } 66 \text { south of Needles-sand at point where it } \\
\text { is inset into scarp in piedmont gravel. }\end{array}$ & Needles \\
\hline
\end{tabular}

${ }^{1}$ Valley distance computed as the straight line distance to a subjectively drawn valley line. See text for explanation.

${ }^{2}$ Elevations are based on postprocessed data. Analysis of 30 elevations collected at known benchmarks produced an average elevation error of $\pm 1.0 \mathrm{~m}$.

${ }^{3}$ Abbreviations: N., north; S., south; E., east; W., west; nr, near; otc, outcrop; ctc, contact; C.R., Colorado River; fm, formation; OSL, optically stimulated luminescence. 
Appendix 2. Summary of particle size data.

[Based on laser particle size analysis by M. Kirby, CSU Fullerton]

\begin{tabular}{|c|c|c|c|c|c|c|c|}
\hline $\begin{array}{c}\text { Sample } \\
\text { Name }\end{array}$ & $\begin{array}{c}\text { Clay } \\
(<0.002 \\
\mathrm{mm})\end{array}$ & $\begin{array}{c}\text { Silt } \\
(0.002- \\
0.0625 \\
\text { mm })\end{array}$ & $\begin{array}{c}\text { Very } \\
\text { Fine } \\
\text { Sand } \\
(0.0625- \\
0.125 \mathrm{~mm})\end{array}$ & $\begin{array}{c}\text { Fine } \\
\text { Sand } \\
(0.125- \\
0.25 \mathrm{~mm})\end{array}$ & $\begin{array}{c}\text { Medium } \\
\text { Sand } \\
(0.25-0.5 \\
\mathrm{mm})\end{array}$ & $\begin{array}{c}\text { Coarse } \\
\text { Sand } \\
(0.5-1 \\
\mathrm{mm})\end{array}$ & $\begin{array}{c}\text { Very } \\
\text { Coarse } \\
\text { Sand } \\
(1-2 \mathrm{~mm})\end{array}$ \\
\hline \multicolumn{8}{|l|}{ Mud facies } \\
\hline \multicolumn{8}{|l|}{ Sand layers } \\
\hline 05-94 OSL & $9 \%$ & $45 \%$ & $33 \%$ & $11 \%$ & $1 \%$ & $0 \%$ & $0 \%$ \\
\hline 05-100-OSL & $12 \%$ & $52 \%$ & $23 \%$ & $10 \%$ & $3 \%$ & $0 \%$ & $0 \%$ \\
\hline 05-305 OSL & $6 \%$ & $37 \%$ & $35 \%$ & $17 \%$ & $3 \%$ & $2 \%$ & $0 \%$ \\
\hline 05-228 OSL & $7 \%$ & $52 \%$ & $34 \%$ & $6 \%$ & $0 \%$ & $0 \%$ & $0 \%$ \\
\hline $05-115$ & $4 \%$ & $35 \%$ & $41 \%$ & $17 \%$ & $2 \%$ & $1 \%$ & $0 \%$ \\
\hline 06-429-1-1 OSL & $12 \%$ & $15 \%$ & $14 \%$ & $33 \%$ & $25 \%$ & $2 \%$ & $0 \%$ \\
\hline $06-429-1-2$ & $16 \%$ & $65 \%$ & $17 \%$ & $1 \%$ & $0 \%$ & $0 \%$ & $0 \%$ \\
\hline $06-429-1-3 a$ & $15 \%$ & $52 \%$ & $27 \%$ & $6 \%$ & $0 \%$ & $0 \%$ & $0 \%$ \\
\hline $06-429-1-4 a$ & $30 \%$ & $65 \%$ & $5 \%$ & $0 \%$ & $0 \%$ & $0 \%$ & $0 \%$ \\
\hline 06-430-4 OSL & $9 \%$ & $13 \%$ & $22 \%$ & $40 \%$ & $16 \%$ & $0 \%$ & $0 \%$ \\
\hline 06-430-11 OSL & $4 \%$ & $34 \%$ & $39 \%$ & $21 \%$ & $2 \%$ & $0 \%$ & $0 \%$ \\
\hline 06-501-4 OSL & $9 \%$ & $37 \%$ & $38 \%$ & $16 \%$ & $0 \%$ & $0 \%$ & $0 \%$ \\
\hline $06-123 b$ & $3 \%$ & $28 \%$ & $40 \%$ & $26 \%$ & $3 \%$ & $0 \%$ & $0 \%$ \\
\hline \multicolumn{8}{|l|}{$06-430-1$ OSL } \\
\hline Average & $10 \%$ & $41 \%$ & $28 \%$ & $16 \%$ & $4 \%$ & $0 \%$ & $0 \%$ \\
\hline \multicolumn{8}{|l|}{ Silt-clay layers } \\
\hline $05-114$ & $64 \%$ & $36 \%$ & $0 \%$ & $0 \%$ & $0 \%$ & $0 \%$ & $0 \%$ \\
\hline $05-123 a$ & $27 \%$ & $67 \%$ & $5 \%$ & $0 \%$ & $0 \%$ & $0 \%$ & $0 \%$ \\
\hline $06-429-1-3 b$ & $73 \%$ & $26 \%$ & $0 \%$ & $0 \%$ & $0 \%$ & $0 \%$ & $0 \%$ \\
\hline \multirow[t]{2}{*}{$06-429-1-4 b$} & $49 \%$ & $51 \%$ & $0 \%$ & $0 \%$ & $0 \%$ & $0 \%$ & $0 \%$ \\
\hline & $53 \%$ & $45 \%$ & $1 \%$ & $0 \%$ & $0 \%$ & $0 \%$ & $0 \%$ \\
\hline \multicolumn{8}{|l|}{ Sand facies } \\
\hline \multicolumn{8}{|l|}{ Typical loose sand } \\
\hline 06-429-3 OSL & $0 \%$ & $1 \%$ & $1 \%$ & $24 \%$ & $54 \%$ & $20 \%$ & $0 \%$ \\
\hline $06-429-1-5$ & $3 \%$ & $3 \%$ & $8 \%$ & $27 \%$ & $35 \%$ & $22 \%$ & $2 \%$ \\
\hline 06-430-3 OSL & $0 \%$ & $2 \%$ & $4 \%$ & $2 \%$ & $38 \%$ & $49 \%$ & $5 \%$ \\
\hline \multirow[t]{2}{*}{ DM-06-501-5 OSL } & $1 \%$ & $3 \%$ & $8 \%$ & $36 \%$ & $45 \%$ & $7 \%$ & $0 \%$ \\
\hline & $1 \%$ & $2 \%$ & $5 \%$ & $22 \%$ & $43 \%$ & $25 \%$ & $2 \%$ \\
\hline \multicolumn{8}{|l|}{ Other samples } \\
\hline \multicolumn{8}{|l|}{ Rhythmite facies } \\
\hline 05-145 OSL & $15 \%$ & $57 \%$ & $24 \%$ & $4 \%$ & $0 \%$ & $0 \%$ & $0 \%$ \\
\hline \multicolumn{8}{|c|}{ Modern Colorado River channel sands at Pearce Ferry } \\
\hline 06-311 & $4 \%$ & $9 \%$ & $39 \%$ & $45 \%$ & $5 \%$ & $0 \%$ & $0 \%$ \\
\hline $06-311-5$ & $10 \%$ & $69 \%$ & $20 \%$ & $0 \%$ & $0 \%$ & $0 \%$ & $0 \%$ \\
\hline \multicolumn{8}{|l|}{ Las Vegas Wash tributary facies } \\
\hline $05-21$ & $16 \%$ & $48 \%$ & $28 \%$ & $8 \%$ & $0 \%$ & $0 \%$ & $0 \%$ \\
\hline
\end{tabular}


Appendix 3. Elevations and valley distances for deposits of the Chemehuevi Formation as mapped by Longwell (1936).

\begin{tabular}{ccccccc}
\hline GIS & Valley & Minimum & Maximum & Minimum & Maximum \\
point & $\begin{array}{c}\text { Distance } \\
(\mathrm{km})\end{array}$ & General Location & $\begin{array}{c}\text { Outcrop } \\
\text { Outcrop } \\
\text { Elevation } \\
(\mathrm{ft})\end{array}$ & $\begin{array}{c}\text { Outcrop } \\
\text { Elevation } \\
(\mathrm{ft})\end{array}$ & $\begin{array}{c}\text { Outcrop } \\
(\mathrm{m})\end{array}$ & $\begin{array}{c}\text { Elevation } \\
(\mathrm{m})\end{array}$ \\
\hline
\end{tabular}

Outcrops along Colorado River Valley described in text by Longwell (1936)

\begin{tabular}{|c|c|c|c|c|c|}
\hline L17 & 590 & Old Callville & 750 & 1,300 & 229 \\
\hline L22 & 655 & Sandy Point & 975 & 1,280 & 270 \\
\hline L23 & 677 & Pearce Ferry South & 1,036 & 1,115 & 316 \\
\hline L24 & 678 & Pearce Ferry North & 1,046 & 1,100 & 319 \\
\hline
\end{tabular}

Base of outcrop 65 feet above river (elevation $685 \mathrm{ft}$ ) (Longwell,

396 1938; p. 1445). Top elevation based on 450' of Longwell's measured section.

Base of outcrop "150 feet higher than the river" (Longwell, 1938; 390 p. 1448); river elevation at time U.S. Geological Survey, 1927) was 825 feet above sea level. Top elevation based on unpublished mapping (K. Howard, unpublished data, 2005).

Top of outcrop reported as 1,165 feet; top of Chemehuevi Fm at 3401,115 feet; thickness of measured section of Chemehuevi Fm is 79 feet.

335 Top of section reported to be 1,100 feet; thickness of measured section 54 feet (Longwell, 1938; p. 1449).

Outcrops only depicted in map plates of Longwell (1936)2:

\begin{tabular}{|c|c|c|c|c|c|c|}
\hline L1 & 574 & Head of Black Cyn & 700 & 1,000 & 213 & 305 \\
\hline L2 & 576 & Boulder Basin & 700 & 1,000 & 213 & 305 \\
\hline L3 & 571 & Boulder Basin & 1,050 & 1,200 & 320 & 366 \\
\hline L4 & 579 & Boulder Basin & 800 & 1,000 & 244 & 305 \\
\hline L5 & 581 & Boulder Basin & 900 & 1,200 & 274 & 366 \\
\hline L11 & 581 & Boulder Basin & 750 & 850 & 229 & 259 \\
\hline L13 & 585 & Boulder Basin & 800 & 900 & 244 & 274 \\
\hline L12 & 584 & Boulder Basin & 800 & 900 & 244 & 274 \\
\hline L14 & 586 & Callville Bay & 950 & 1,200 & 290 & 366 \\
\hline L15 & 586 & Callville Bay & 1,100 & 1,200 & 335 & 366 \\
\hline L16 & 587 & Callville Bay & 1,200 & 1,250 & 366 & 381 \\
\hline L21 & 656 & Across from Sandy Point & 850 & 1,000 & 259 & 305 \\
\hline
\end{tabular}

Outcrops mapped by Longwell (1936)3 in Las Vegas Wash

\begin{tabular}{|c|c|c|c|c|c|}
\hline L6 & Las Vegas Wash & 1,100 & 1,200 & 335 & 366 \\
\hline $\mathrm{L} 7$ & Las Vegas Wash & 1,300 & 1,325 & 396 & 404 \\
\hline L8 & Las Vegas Wash & 1,250 & 1,350 & 381 & 41 \\
\hline L9 & Las Vegas Wash & 1,100 & 1,150 & 335 & 35 \\
\hline L10 & Las Vegas Wash & 1,000 & 1,100 & 305 & 33 \\
\hline
\end{tabular}


Appendix 3. Elevations and valley distances for deposits of the Chemehuevi Formation as mapped by Longwell (1936).—Continued

\begin{tabular}{|c|c|c|c|c|c|c|c|}
\hline $\begin{array}{l}\text { GIS } \\
\text { point }\end{array}$ & $\begin{array}{c}\text { Valley } \\
\text { Distance }^{1} \\
(\mathbf{k m})\end{array}$ & General Location & $\begin{array}{c}\text { Minimum } \\
\text { Outcrop } \\
\text { Elevation } \\
(\mathrm{ft})\end{array}$ & $\begin{array}{c}\text { Maximum } \\
\text { Outcrop } \\
\text { Elevation } \\
\text { (ft) }\end{array}$ & $\begin{array}{c}\text { Minimum } \\
\text { Outcrop } \\
\text { Elevation } \\
(\mathrm{m})\end{array}$ & $\begin{array}{c}\text { Maximum } \\
\text { Outcrop } \\
\text { Elevation } \\
(\mathrm{m})\end{array}$ & Notes \\
\hline \multicolumn{8}{|c|}{ Outcrops in Virgin River Valley } \\
\hline L18 & & Virgin River & 1,100 & 1,200 & 335 & 366 & \\
\hline L19 & & Virgin River & 1,050 & 1,100 & 320 & 335 & \\
\hline $\mathrm{L} 20$ & & Virgin River & 1,200 & 1,300 & 366 & 396 & \\
\hline
\end{tabular}

${ }^{1}$ Distance measured along valley line (see text).

${ }^{2}$ Elevations estimated to nearest half contour on Longwell's plates. 
Appendix 4. Measured section of the Old Callville remnant of the Chemehuevi Formation as described by Longwell (1936, p. 14451446).

\begin{tabular}{|c|c|c|c|c|c|c|}
\hline $\begin{array}{l}\text { Interval } \\
\text { No. }\end{array}$ & $\begin{array}{l}\text { Measured } \\
\text { Interval } \\
\text { thickness, } \\
\text { (ft) }\end{array}$ & $\begin{array}{l}\text { Interval } \\
\text { Thickness, } \\
\text { (cm) }\end{array}$ & $\begin{array}{c}\text { Cumulative } \\
\text { Thickness, } \\
\text { (m) }\end{array}$ & $\begin{array}{c}\text { Elevation of } \\
\text { Top of } \\
\text { Interval (m) }\end{array}$ & Description (from Longwell, 1936) & Comment \\
\hline & 50 & 1,524 & 152.4 & $\begin{array}{c}381.0(1250 \\
\mathrm{ft})\end{array}$ & Sand dunes, forming rolling surface. & not clearly river laid \\
\hline & & & & $\begin{array}{c}365.8(1200 \\
\mathrm{ft})\end{array}$ & Highest exposure of water-laid sand. & \\
\hline \multicolumn{7}{|c|}{ Chemehuevi Formation } \\
\hline & 1.9 & 58 & 137.2 & 365.8 & $\begin{array}{l}\text { Pavement veneer, containing river } \\
\text { gravel }^{1}\end{array}$ & rhythmite facies \\
\hline 19 & 38 & 1,158 & 136.6 & 365.2 & Coarse cross-bedded sand & rhythmite facies \\
\hline 18 & 1.2 & 36 & 125.0 & 353.6 & $\begin{array}{l}\text { Hard gray clay with obscure } \\
\text { lamination. }\end{array}$ & rhythmite facies \\
\hline 17 & 3 & 91 & 124.6 & 353.2 & Coarse sand with some cross-bedding. & rhythmite facies \\
\hline 16 & 4 & 122 & 123.7 & 352.3 & Gray clay and silt, interlayered. & rhythmite facies \\
\hline 15 & 1 & 30 & 122.5 & 351.1 & Sand, rather fine-grained. & rhythmite facies \\
\hline 14 & 1 & 30 & 122.2 & 350.8 & Gray clay. & rhythmite facies \\
\hline 13 & 27 & 823 & 121.9 & 350.5 & Coarse cross-bedded sand, finer at top. & rhythmite facies \\
\hline 12 & 4 & 122 & 113.7 & 342.3 & Hard gray clay, in part gritty. & rhythmite facies \\
\hline 11 & 42 & 1,280 & 112.5 & 341.0 & $\begin{array}{l}\text { Coarse cross-bedded sand grading } \\
\text { upward into silt. }\end{array}$ & rhythmite facies \\
\hline 10 & 1 & 30 & 99.7 & 328.2 & Gray clay and silt, interlayered. & rhythmite facies \\
\hline 9 & 27 & 823 & 99.4 & 327.9 & Coarse cross-bedded sand. & rhythmite facies \\
\hline 8 & 0.4 & 13 & 91.1 & 319.7 & Clay and fine silt. & rhythmite facies \\
\hline 7 & 2 & 61 & 91.0 & 319.6 & Fine sand. & rhythmite facies \\
\hline 6 & 0.5 & 15 & 90.4 & 319.0 & Clay and fine silt. & rhythmite facies \\
\hline 5 & 3 & 91 & 90.2 & 318.8 & Sand, medium-grained. & rhythmite facies \\
\hline 4 & 1 & 30 & 89.3 & 317.9 & Gray clay and silt, interlayered. & rhythmite facies \\
\hline 3 & 93 & 2,835 & 89.0 & 317.6 & $\begin{array}{l}\text { Coarse cross-bedded sand, without } \\
\text { break. }\end{array}$ & rhythmite facies \\
\hline 2 & 3 & 91 & 60.7 & 289.3 & Gray silt, with clay at top. & rhythmite facies \\
\hline \multirow[t]{3}{*}{1} & 11 & 335 & 59.8 & 288.3 & Coarse sand, finer at top. & rhythmite facies \\
\hline & 60 & 1,829 & 56.4 & 285.0 & $\begin{array}{l}\text { Clay, silt, and fine sand, in thin layers, } \\
\text { forming cliffs. }\end{array}$ & mud facies \\
\hline & 125 & 3,810 & 38.1 & 266.7 & $\begin{array}{l}\text { Coarse cross-bedded coarse sand, } \\
\text { poorly exposed, with at least two layers } \\
\text { of clay and silt; perceptible carbonate } \\
\text { cement; gray volcanic ash bed up to } 3 \\
\text { m thick near top of member. }\end{array}$ & lower sand facies (?) \\
\hline \multicolumn{7}{|c|}{ Not exposed } \\
\hline & 65 & 1981 & & 228.6 & Gental slope to river, with no outcrops. & \\
\hline & & & & $208.8(685 \mathrm{ft})^{2}$ & Low water elevation of river. & \\
\hline
\end{tabular}

${ }^{1}$ Thickness inferred from Longwell (1936) but not explicitly stated.

${ }^{2}$ River elevation from 1927 topographic map (U.S. Geological Survey, 1927). 
Appendix 5. Measured section of the Chemehuevi Formation at Sandy Point, $25 \mathrm{~km}$ downstream from the mouth of Grand Canyon as described by Longwell (1936, p. 1448).

\begin{tabular}{cccccll}
\hline $\begin{array}{c}\text { Interval } \\
\text { No. }\end{array}$ & $\begin{array}{c}\text { Interval } \\
\text { Thickness } \\
(\mathbf{f t})^{1}\end{array}$ & $\begin{array}{c}\text { Interval } \\
\text { Thickness } \\
(\mathbf{c m})\end{array}$ & $\begin{array}{c}\text { Cumulative } \\
\text { Thickness }(\mathbf{m})\end{array}$ & $\begin{array}{c}\text { Elevation of } \\
\text { Top of } \\
\text { Interval }(\mathbf{m})^{2}\end{array}$ & $\begin{array}{l}\text { Description } \\
(\text { from Longwell, 1936) }\end{array}$ & Comment \\
\hline 3 & 10 & 305 & 124.9 & 396.2 & $\begin{array}{l}\text { River gravels, moderately } \\
\text { cemented }\end{array}$ & $\begin{array}{l}\text { terrace } \\
\text { gravel unit }\end{array}$ \\
\hline \multicolumn{2}{c}{} & 10 & & & & \\
\hline 2 & 370 & 11,278 & 121.9 & 393.2 & $\begin{array}{l}\text { Twenty gigantic "varves" like } \\
\text { that in upper member at } \\
\text { Callville }\end{array}$ & $\begin{array}{l}\text { rhythmite } \\
\text { facies }\end{array}$ \\
1 & $20-40^{3}$ & 91 & 9.1 & 280.4 & River gravel & $\begin{array}{l}\text { basal gravel } \\
\text { member(?) }\end{array}$ \\
\hline
\end{tabular}

${ }^{1}$ As reported by Longwell (1936, p. 1448).

${ }^{2}$ Calculated from top of mesa, reported by Longwell to be 1,300 ft (396.2 m).

${ }^{3}$ Assumed to be $30 \mathrm{ft}$. 
Appendix 6. Measured sections of the Chemehuevi Formation near the mouth of Grand Canyon as described by Longwell (1936, p. 1448-1449).

\begin{tabular}{|c|c|c|c|c|c|}
\hline $\begin{array}{l}\text { Interval } \\
\text { No. }\end{array}$ & $\begin{array}{c}\text { Interval } \\
\text { Thickness } \\
\text { (ft) }\end{array}$ & $\begin{array}{c}\text { Interval } \\
\text { Thickness } \\
\text { (cm) }\end{array}$ & $\begin{array}{c}\text { Cumulative } \\
\text { Thickness } \\
\text { (m) }\end{array}$ & $\begin{array}{l}\text { Elevation } \\
\text { of Top of } \\
\text { Interval } \\
\text { (m) }\end{array}$ & $\begin{array}{l}\text { Description } \\
\text { (from Longwell, 1936) }\end{array}$ \\
\hline \multicolumn{6}{|c|}{ Section measured south of the river, near Pearce Ferry } \\
\hline \multicolumn{6}{|c|}{ Terrace gravel sequence } \\
\hline & 50 & 1524 & 39.4 & 355.1 & River gravels $^{1}$ \\
\hline \multicolumn{6}{|c|}{ Chemehuevi Formation, rhythmite facies } \\
\hline 18 & 6 & 183 & 24.2 & 339.9 & Coarse cross-bedded sand \\
\hline 17 & 0.8 & 25 & 22.3 & 338.0 & Clay and silt \\
\hline 16 & 7 & 213 & 22.1 & 337.8 & Coarse cross-bedded sand \\
\hline 15 & 1 & 30 & 19.9 & 335.6 & Clay and silt \\
\hline 14 & 9 & 274 & 19.6 & 335.3 & Coarse cross-bedded sand \\
\hline 13 & 1.5 & 46 & 16.9 & 332.6 & Clay and silt \\
\hline 12 & 9 & 274 & 16.4 & 332.1 & Coarse cross-bedded sand \\
\hline 11 & 1.3 & 41 & 13.7 & 329.4 & Clay and silt \\
\hline 10 & 10 & 305 & 13.3 & 329.0 & Coarse cross-bedded sand \\
\hline 9 & 1.3 & 38 & 10.2 & 325.9 & Clay \\
\hline 8 & 2.5 & 76 & 9.9 & 325.6 & Cross-bedded sand \\
\hline 7 & 2.7 & 81 & 9.1 & 324.8 & Clay and silt \\
\hline 6 & 3 & 91 & 8.3 & 324.0 & Cross-bedded sand \\
\hline 5 & 1.2 & 36 & 7.4 & 323.1 & Clay and silt \\
\hline 4 & 3.5 & 107 & 7.0 & 322.7 & Cross-bedded sand \\
\hline 3 & 2.5 & 76 & 5.9 & 321.6 & Clay and silt \\
\hline 2 & 16 & 488 & 5.2 & 320.9 & Coarse cross-bedded sand \\
\hline 1 & 1 & 30 & 0.3 & 316.0 & Clay \\
\hline
\end{tabular}

Partial section measured north of the river, near Pearce Ferry

\begin{tabular}{cccccl}
\hline & \multicolumn{5}{c}{ Chemehuevi } \\
\hline 12 & 1.2 & 36 & 16.5 & 335.3 & Clay \\
11 & 7.5 & 229 & 16.2 & 334.9 & Sand \\
10 & 0.8 & 25 & 13.9 & 332.6 & Clay \\
9 & 13.5 & 411 & 13.6 & 332.4 & Sand \\
8 & 2.8 & 84 & 9.5 & 328.3 & Clay \\
7 & 11 & 335 & 8.7 & 327.4 & Sand \\
6 & 2.5 & 76 & 5.3 & 324.1 & Clay \\
5 & 3.4 & 104 & 4.5 & 323.3 & Sand \\
4 & 1.7 & 51 & 3.5 & 322.3 & Clay \\
3 & 5 & 152 & 3.0 & 321.8 & Sand \\
2 & 3.3 & 102 & 1.5 & 320.2 & Clay \\
1 & 1.5 & 46 & 0.5 & 319.2 & Sand \\
\hline
\end{tabular}

\footnotetext{
${ }^{1}$ The upper gravel interval was not considered by Longwell to be part of the Chemehuevi Formation.
} 
Appendix 7. Lithologic log of well LCRP-15, 3 km southeast of Parker, Ariz.

[Based on examination of drill cuttings by D.G. Metzger; Metzger and others, 1973b, p. G125]

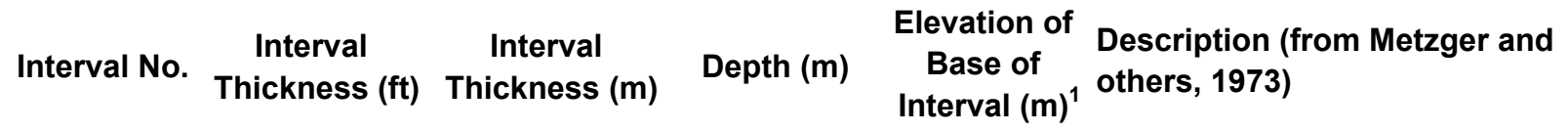

\begin{tabular}{|c|c|c|c|c|c|}
\hline 30 & 27 & 8.2 & 8.2 & 145.7 & $\begin{array}{l}\text { Sand, medium, grayish-orange, } \\
\text { fairly well sorted. }\end{array}$ \\
\hline 29 & 1 & 0.3 & 8.5 & 145.4 & Clay, light-brown. \\
\hline 28 & 14 & 4.3 & 12.8 & 141.1 & $\begin{array}{l}\text { Sand, medium, grayish-orange, } \\
\text { fairly well sorted. }\end{array}$ \\
\hline 27 & 19 & 5.8 & 18.6 & 135.3 & $\begin{array}{l}\text { Sand, medium to fine, grayish } \\
\text { orange, fairly well sorted. }\end{array}$ \\
\hline 26 & 3 & 0.9 & 19.5 & 134.4 & $\begin{array}{l}\text { Sand, medium to fine, grayish- } \\
\text { orange, fairly well sorted; with } 10 \\
\text { percent gravel as much as } 2 \text { in. in } \\
\text { diameter. }\end{array}$ \\
\hline 25 & 8 & 2.4 & 21.9 & 132.0 & $\begin{array}{l}\text { Sand, medium to fine, grayish- } \\
\text { orange, fairly well sorted; few } \\
\text { pebbles; some cemented streaks } \\
\text { a quarter of an inch thick. }\end{array}$ \\
\hline 24 & 8 & 2.4 & 24.4 & 129.5 & $\begin{array}{l}\text { Sand, fine to very coarse, grayish } \\
\text { orange, poorly sorted, with } 10 \\
\text { percent gravel; some cemented } \\
\text { streaks a quarter of an inch thick. }\end{array}$ \\
\hline 23 & 8 & 2.4 & 26.8 & 127.1 & $\begin{array}{l}\text { Sand, fine to medium, grayish- } \\
\text { orange, fairly well sorted; few } \\
\text { subangular to rounded gravel as } \\
\text { much as } 3 \text { in. in diameter. }\end{array}$ \\
\hline 22 & 4 & 1.2 & 28.0 & 125.9 & $\begin{array}{l}\text { Sand, fine, grayish orange, fairly } \\
\text { well sorted. }\end{array}$ \\
\hline 21 & 4 & 1.2 & 29.3 & 124.6 & $\begin{array}{l}\text { Sand, fine to coarse, grayish } \\
\text { orange, poorly sorted; about } 20 \\
\text { percent subangular to rounded } \\
\text { gravel as much as } 3 \text { in. diameter. }\end{array}$ \\
\hline 20 & 4 & 1.2 & 30.5 & 123.4 & $\begin{array}{l}\text { Sand, fine, grayish orange, fairly } \\
\text { well sorted; with occasional } \\
\text { pebble. }\end{array}$ \\
\hline 19 & 6 & 1.8 & 32.3 & 121.6 & $\begin{array}{l}\text { Sand, fine to coarse, grayish } \\
\text { orange, poorly sorted; about } 20 \\
\text { percent subangular to rounded } \\
\text { gravel as much as } 3 \text { in. diameter. }\end{array}$ \\
\hline 18 & 2 & 0.6 & 32.9 & 121.0 & $\begin{array}{l}\text { Sand, medium to fine, grayish- } \\
\text { orange, with } 20 \text { percent granules } \\
\text { and pebbles. }\end{array}$ \\
\hline
\end{tabular}


Appendix 7. Lithologic log of well LCRP-15, 3 km southeast of Parker, Ariz.-Continued

[Based on examination of drill cuttings by D.G. Metzger; Metzger and others, 1973b, p. G125]

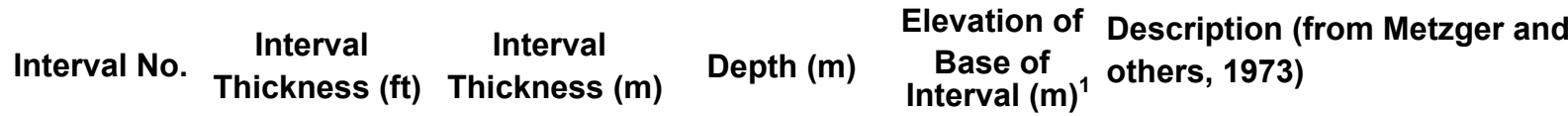

\begin{tabular}{|c|c|c|c|c|c|}
\hline 17 & 34 & 10.4 & 43.3 & 110.6 & $\begin{array}{l}\text { Gravel as much as } 6 \text { in. in } \\
\text { diameter, subangular to rounded; } \\
\text { some clayballs; about } 10 \text { percent } \\
\text { sand. }\end{array}$ \\
\hline 16 & 3 & 0.9 & 44.2 & 109.7 & $\begin{array}{l}\text { Sand, very coarse, grayish } \\
\text { orange; about } 20 \text { percent gravel } \\
\text { as much as } 2 \text { in. diameter. }\end{array}$ \\
\hline 15 & 8 & 2.4 & 46.6 & 107.3 & $\begin{array}{l}\text { Gravel as much as } 7 \text { in. in } \\
\text { diameter, rounded to well } \\
\text { rounded; } 10 \text { percent sand. }\end{array}$ \\
\hline 14 & 5 & 1.5 & 48.2 & 105.7 & $\begin{array}{l}\text { Clay, grayish orange; embedded } \\
\text { small pebbles; iron streaks } \\
\text { throughout. }\end{array}$ \\
\hline 13 & 7 & 2.1 & 50.3 & 103.6 & $\begin{array}{l}\text { Sand, coarse to very coarse, fairly } \\
\text { well sorted; } 30 \text { percent granules } \\
\text { and small pebbles. }\end{array}$ \\
\hline 12 & 11 & 3.4 & 53.6 & 100.3 & $\begin{array}{l}\text { Gravel as much as } 9 \text { in. in } \\
\text { diameter, rounded to well- } \\
\text { rounded; } 30 \text { percent sand. }\end{array}$ \\
\hline 11 & 23 & 7.0 & 60.7 & 93.2 & $\begin{array}{l}\text { Gravel as much as } 11 \text { in. in } \\
\text { diameter, subrounded to well- } \\
\text { rounded; some greenish gray } \\
\text { clayballs; } 10 \text { percent sand. }\end{array}$ \\
\hline \multicolumn{6}{|c|}{ Bouse Formation } \\
\hline 10 & 9 & 2.7 & 63.4 & 90.5 & $\begin{array}{l}\text { Claystone, banded, greenish gray, } \\
\text { grayish-yellow, and very light gray. }\end{array}$ \\
\hline 9 & 4 & 1.2 & 64.6 & 89.3 & $\begin{array}{l}\text { Claystone, light olive gray with } \\
\text { some moderate-yellow; embedded } \\
\text { small pebbles. }\end{array}$ \\
\hline 8 & 54 & 16.5 & 81.1 & 72.8 & $\begin{array}{l}\text { Claystone, light olive gray, } \\
\text { fossiliferous; some siltstone; } \\
\text { scattered embedded well-rounded } \\
\text { pebbles as much as } 2 \text { in. in } \\
\text { diameter. }\end{array}$ \\
\hline 7 & 9 & 2.7 & 83.8 & 70.1 & Marl, yellowish gray, fossiliferous. \\
\hline \multicolumn{6}{|c|}{ Fanglomerate } \\
\hline 6 & 61 & 18.6 & 102.4 & 51.5 & $\begin{array}{l}\text { Gravel as much as } 6 \text { in. in } \\
\text { diameter, cemented, poorly } \\
\text { sorted, reddish-brown, } \\
\text { subrounded to subangular; } 40 \\
\text { percent sand. }\end{array}$ \\
\hline 5 & 63 & 19.2 & 121.6 & 32.3 & $\begin{array}{l}\text { Conglomerate, gray, subangular } \\
\text { to subrounded. } \\
\text { Sand, cemented, reddish-brown, }\end{array}$ \\
\hline
\end{tabular}


Appendix 7. Lithologic log of well LCRP-15, 3 km southeast of Parker, Ariz.-Continued

[Based on examination of drill cuttings by D.G. Metzger; Metzger and others, 1973b, p. G125]

\begin{tabular}{|c|c|c|c|c|c|}
\hline Interval No. & $\begin{array}{l}\text { Interval } \\
\text { Thickness (ft) }\end{array}$ & $\begin{array}{l}\text { Interval } \\
\text { Thickness (m) }\end{array}$ & Depth (m) & $\begin{array}{l}\text { Elevation of } \\
\text { Base of } \\
\text { Interval }(\mathrm{m})^{1}\end{array}$ & $\begin{array}{l}\text { Description (from Metzger and } \\
\text { others, 1973) }\end{array}$ \\
\hline 3 & 11 & 3.4 & 145.1 & 8.8 & $\begin{array}{l}\text { Sand, cemented, reddish brown, } \\
\text { poorly sorted; } 40 \text { percent } \\
\text { subangular gravel. }\end{array}$ \\
\hline 2 & 19 & 5.8 & 150.9 & 3.0 & $\begin{array}{l}\text { Sand, cemented, reddish brown, } \\
\text { poorly sorted; some granules and } \\
\text { small pebbles. }\end{array}$ \\
\hline 1 & 25 & 7.6 & 158.5 & -4.6 & $\begin{array}{l}\text { Sand, cemented, reddish brown, } \\
\text { poorly sorted; subangular to } \\
\text { subrounded gravel as much as } 1 \\
\text { in. in diameter. }\end{array}$ \\
\hline
\end{tabular}

${ }^{1}$ Elevation of base of bed, based on surface well elevation of $153.9 \mathrm{~m}$ (505 feet) above sea level, as read from Parker 7.5-minute topographic quadrangle. 
Appendix 8. Measured section of part of an exposure of the mud facies of the Chemehuevi Formation at the site of tephra occurrence near Monkey Rock, Ariz.

[Measured by K. Howard, D. Malmon, and S. Lundstrom on March 3, 2005]

\begin{tabular}{|c|c|c|c|c|}
\hline Interval Number & $\begin{array}{l}\text { Interval Thickness } \\
\text { cm }\end{array}$ & $\begin{array}{c}\text { Cumulative } \\
\text { Thickness } \\
\text { cm }\end{array}$ & $\begin{array}{c}\text { Elevation of Top of } \\
\text { Interval } \\
\mathbf{m}^{1}\end{array}$ & Description \\
\hline & & & 262.18 & Top of cleared exposure within part of mud facies. \\
\hline \multicolumn{5}{|c|}{ Mud Facies } \\
\hline 31 & 11 & 286 & 262.18 & $\begin{array}{l}\text { or laminae in lower } 7 \mathrm{~cm} \text { of bed, overlain by zone of small clay } \\
\text { balls. }\end{array}$ \\
\hline 30 & 14 & 275 & 262.07 & $\begin{array}{l}\text { Mud, color } 10 \mathrm{R} 4 / 2 \text {; has discontinuous wavy stringer of silty very } \\
\text { fine sand at } 270 \mathrm{~cm} \text {. }\end{array}$ \\
\hline 29 & 10 & 261 & 261.93 & Clayey silt, moderate reddish brown, color $10 \mathrm{R} 4 / 6$. \\
\hline 28 & 2 & 251 & 261.83 & $\begin{array}{l}\text { Silty very fine sand, color } 10 Y R 6 / 4 \text {, wavy bed; waves } 2 \text { to } 3 \mathrm{~cm} \\
\text { amplitude and } 10 \mathrm{~cm} \text { wavelength. }\end{array}$ \\
\hline 27 & 23 & 249 & 261.81 & $\begin{array}{l}\text { Mud, color } 10 \mathrm{R} 4 / 2 \text {, exhibiting two discontinuous silt layers } 0.5-1 \\
\mathrm{~cm} \text { thick at } 235 \text { and } 240 \mathrm{~cm} \text {. }\end{array}$ \\
\hline 26 & 1 & 226 & 261.58 & Silty very fine sand, color $10 Y R$ 6/4. \\
\hline 25 & 15 & 225 & 261.57 & Mud, color 10R 4/2. \\
\hline 24 & 4 & 210 & 261.42 & $\begin{array}{l}\text { Silty very fine sand, color } 10 Y R 6 / 4 \text {, with orange oxidized upper } \\
\text { contact. }\end{array}$ \\
\hline 23 & 8 & 206 & 261.38 & Mud, color 10R 4/2. \\
\hline 22 & 4 & 198 & 261.30 & Silty very fine sand, color 10YR 6/4. \\
\hline 21 & 3 & 194 & 261.26 & $\begin{array}{l}\text { Clayey silt, moderate reddish brown, color } 10 \mathrm{R} 4 / 6 \text {. } \\
\text { TEPHRA BED. White or silver silt size volcanic ash, with }\end{array}$ \\
\hline 20 & 13 & 191 & 261.23 & $\begin{array}{l}\text { persistent } 3 \mathrm{~mm} \text { thick brown mud band at } 190 \mathrm{~cm} \text { overlain by } \\
\text { dirtier ash. Upper contact of ash is abrubpt and wavy with } 1 \text { to } 4 \\
\mathrm{~cm} \text { of relief, wavelength } 2-6 \mathrm{~cm} \text {. Locality } 05-94 \text { in appendix } 1 \text {. }\end{array}$ \\
\hline 19 & 5 & 178 & 261.10 & Silty fine sand. \\
\hline 18 & 13 & 173 & 261.05 & Very hard mud layer, color 10R 4/2, containing much gypsum. \\
\hline 17 & 2 & 160 & 260.92 & Continuous 2-cm-thick silty fine sand bed, color 10YR 6/4. \\
\hline 16 & 22 & 158 & 260.90 & Mud, color 10R 4/2, containing much gypsum (hard layer). \\
\hline 15 & 5 & 136 & 260.68 & $\begin{array}{l}\text { Silty very fine sand; contains central dark mud layer parallel to } \\
\text { bed. Contact exhibits fingers of sand, } 2 \text { to } 5 \mathrm{~cm} \text { wide and } 3 \text { to } 5 \\
\mathrm{~cm} \text { deep, down into underlying mud. }\end{array}$ \\
\hline 14 & 39 & 131 & 260.63 & $\begin{array}{l}\text { Mud, color } 10 \mathrm{R} 4 / 2 \text {, containing two subhorizontal stringers of very } \\
\text { fine sand at } 105 \mathrm{~cm} \text { and } 121 \mathrm{~cm} \text {. }\end{array}$ \\
\hline 13 & 5 & 92 & 260.24 & Silty very fine sand, partly laminated (has three or four laminae). \\
\hline 12 & 9 & 87 & 260.19 & Mud, color 10R 4/2. \\
\hline 11 & 10 & 78 & 260.10 & $\begin{array}{l}\text { Silty very fine sand, color } 10 Y R \text { 6/4, layer varies in thickness; } \\
\text { upper contact has } 2 \mathrm{~cm} \text { relief with wavelength } 10 \text { to } 20 \mathrm{~cm} \text {; OSL } \\
\text { sample } 05-94 \text { ' collected here in } 2006 \text {. }\end{array}$ \\
\hline 10 & 10 & 68 & 260.00 & Mud, color 10R 4/2. \\
\hline 9 & 5 & 58 & 259.90 & Silty fine sand, color $10 Y R 6 / 4$, with oxidized lower contact. \\
\hline 8 & 3 & 53 & 259.85 & Discontinuouous clay-rich zone, color 10R 4/2. \\
\hline 7 & 3 & 50 & 259.82 & Very fine sand and coarse silt, color 10YR 6/4. \\
\hline 6 & 5 & 47 & 259.79 & $\begin{array}{l}\text { Discontinuous clay-rich boudin-like bodies } 6 \text { to } 15 \mathrm{~cm} \text { diameter } \\
\text { with color } 10 \mathrm{R} 4 / 2 \text {, surrounded by orange oxidation zones } 2 \text { to } 3 \\
\mathrm{~mm} \text { thick. Clay boudins separated by vertical columns of fine } \\
\text { sand that connect to sand intervals above and below. }\end{array}$ \\
\hline 5 & 9 & 42 & 259.74 & Very fine sand and coarse silt, color 10YR 6/4. \\
\hline 4 & 8 & 33 & 259.65 & Silty clay with gypsum crystals, color 10R 4/2. \\
\hline 3 & 8 & 25 & 259.57 & Silty very fine sand, color $10 \mathrm{YR} 6 / 4$. \\
\hline 2 & 5 & 17 & 259.49 & Wavy interval of clayey silty fine sand. \\
\hline \multirow[t]{2}{*}{1} & 12 & 12 & 259.44 & Silty very fine sand, color 10YR 6/4. \\
\hline & & 0 & 259.32 & Discontinuous clay. \\
\hline
\end{tabular}

${ }^{1}$ Elevation of top of interval, computed relative to the GPS-measured elevation of the base of the tephra bed (261.1 m asl; GPS location 05-94, appendix 1). 
Appendix 9. Reference section of the Chemehuevi Formation near Katherine Landing, Ariz. [Measured by D. Malmon and K. Howard]

\begin{tabular}{|c|c|c|c|c|c|c|}
\hline & & Locality information $^{1}$ & Latitude & Longitude & Elevation $(\mathrm{m})$ & $\begin{array}{l}\text { Notes } \\
07-424-4 \text {-Tan of hill: litter of abundant calcite-cemented plant casts }\end{array}$ \\
\hline & & $\begin{array}{l}\text { GPS top of section } \\
\text { Base of section }\end{array}$ & $3513.2346+$ & 11434.2306 - & $\begin{array}{c}215.79 \\
196.3 \\
\end{array}$ & $\begin{array}{l}\text { 07-424-4-Top of hill; litter of abundant calcite-cemented plant casts. } \\
\text { Lake Mohave elevation (Apr-May 2007). }\end{array}$ \\
\hline $\begin{array}{l}\text { Interval } \\
\text { Number }\end{array}$ & $\begin{array}{l}\text { Interval } \\
\text { Thickness }(\mathrm{cm})\end{array}$ & $\begin{array}{c}\text { Cumulative } \\
\text { Thickness } \\
(\mathbf{m})\end{array}$ & $\begin{array}{c}\text { Relative } \\
\text { Resistance to } \\
\text { Erosion }{ }^{2} \\
\end{array}$ & $\begin{array}{c}\text { Alphabetic } \\
\text { Interval }^{3}\end{array}$ & $\begin{array}{l}\text { Elevation of Top of } \\
\text { Interval } \\
(\mathbf{m})^{4}\end{array}$ & Description \\
\hline \multicolumn{7}{|c|}{ Sand Facies } \\
\hline 44 & 23 & 20.4 & 2 & $\mathrm{H}$ & $\begin{array}{l}216.9 \\
216.7\end{array}$ & $\begin{array}{l}\text { Top of exposure. } \\
\text { Loose sand and carbonate-cemented root mat. } \\
\text { Poorly exposed unconsolidated sand in planar to concave-up crossbeds; angle }\end{array}$ \\
\hline 43 & 174 & 20.17 & 1 & H & 216.5 & $\begin{array}{l}\text { between sets as great as } 20-30^{\circ} \text {. Abundant calcareous casts of plant roots and } \\
\text { stems. }\end{array}$ \\
\hline 42 & 66 & 18.43 & 1 & $\mathrm{H}$ & 214.7 & Poorly exposed crossbedded sand; vertical calcareous tubes (casts of plants). \\
\hline 41 & 6 & 17.77 & 3 & $\mathrm{H}$ & 214.1 & Cemented pebbly sand. \\
\hline 40 & 35 & 17.71 & 2 & $\mathrm{H}$ & 214.0 & Slightly consolidated medium sand; ripple crossbedding. \\
\hline 39 & 156 & 17.36 & 1 & $\mathrm{H}$ & 213.7 & Poorly exposed unconsolidated crossbedded pebbly sand. \\
\hline 38 & 46 & 15.8 & 3 & G & 212.1 & Carbonate-cemented pebbly sand; base is planar. \\
\hline 37 & 23 & 15.34 & 2 & G & 211.6 & $\begin{array}{l}\text { Poorly consolidated medium sand, crossbedded: horizontal to steep, concave } \\
\text { up, tnagential at base. }\end{array}$ \\
\hline 36 & 6 & 15.11 & 2 & G & 211.4 & $\begin{array}{l}\text { Rust colored zone of sand with fist-sized mudball and angular small to coarse } \\
(32 \mathrm{~mm}) \text { pebbles. }\end{array}$ \\
\hline 35 & 107 & 15.05 & 2 & G & 211.4 & $\begin{array}{l}\text { Poorly consolidated medium sand with horizontal to steep crossbeds; cemented } \\
\text { lenses; } 1 \text { lamina of magnetite(?) black sand. }\end{array}$ \\
\hline 34 & 12 & 13.98 & 1 & G & 210.3 & $\begin{array}{l}\text { Slightly consolidated medium sand, horizontally laminated; horizontal and } \\
\text { vertical calcite tubes (root casts) present, crossing undisturbed laminations. }\end{array}$ \\
\hline 33 & 20 & 13.86 & 1 & G & 210.2 & Unconsolidated medium quartz sand; planar laminations dip south 4 to $5^{\circ}$. \\
\hline 32 & 2 & 13.66 & 3 & $\mathrm{~F}$ & 210.0 & Cemented pebbly sand, mostly quartz, some biotite. \\
\hline 31 & 17 & 13.64 & 1 & $\mathrm{~F}$ & 209.9 & Unconsolidated white sand, laminated more or less horizontally. \\
\hline 30 & 6 & 13.47 & 3 & $\mathrm{~F}$ & 209.8 & Carbonate-cemented pebbly sand, mottled; pebbles as large as $4 \mathrm{~cm}$. \\
\hline 29 & 52 & 13.41 & 2 & $\mathrm{~F}$ & 209.7 & Poorly consolidated medium sand; horizontal planar laminations. \\
\hline 28 & 41 & 12.89 & & $\mathrm{~F}$ & 209.2 & Yellow medium sand, partly covered. \\
\hline 27 & 12 & 12.48 & & $\mathrm{~F}$ & 208.8 & $\begin{array}{l}\text { Well sorted medium sand, ripple cross bedded; truncates underlying section; } \\
\text { along strike the basal } 5 \mathrm{~cm} \text { is pebbly. }\end{array}$ \\
\hline 26 & 58 & 12.36 & & $\mathrm{~F}$ & 208.7 & Finely laminated sand, well sorted, crossbeds dip gently to planar. \\
\hline 25 & 12 & 11.78 & 3 & $\mathrm{~F}$ & 208.1 & Gravelly sand with mudballs; steeply crossbedded; local rust colored zone. \\
\hline 24 & 35 & 11.66 & 2 & $\mathrm{~F}$ & 208.0 & $\begin{array}{l}\text { Yellowish crossbedded sand; concave-up crossbeds tangential at base. } \\
\text { Pebbly sand, laminated, crossbedded; upper set is planar and steep and lower }\end{array}$ \\
\hline 23 & 34 & 11.31 & 2 & $\mathrm{~F}$ & 207.6 & $\begin{array}{l}\text { set is planar with gentler dip; pebbles as large as } 2 \mathrm{~cm} \text { (intermediate diameter); } \\
\text { lower part has granules. }\end{array}$ \\
\hline 22 & 20 & 10.97 & 2 & $\mathrm{~F}$ & 207.3 & $\begin{array}{l}\text { Lower part of } 89-\mathrm{cm} \text { interval in sets } 0.5-1 \mathrm{~m} \text { thick of gently dippping, } \\
\text { laminated, crossbedded sand. }\end{array}$ \\
\hline 21 & 170 & 10.77 & 2 & $\mathrm{~F}$ & 207.1 & Crossbedded sand in several complex sets (river sand); rust colored zones. \\
\hline 20 & 55 & 9.07 & 2 & $\mathrm{~F}$ & 205.4 & $\begin{array}{l}\text { Medium to coarse, well sorted sand; laminated as foresets that bed down to } 30^{\circ} \\
\text { dips from topsets;tangential at base. }\end{array}$ \\
\hline 19 & 48 & 8.52 & 1 & $\mathrm{~F}$ & 204.8 & Poorly exposed; Fines upward from pebbly sand to sand. \\
\hline
\end{tabular}


Appendix 9. Reference section of the Chemehuevi Formation near Katherine Landing, Ariz.-Continued

[Measured by D. Malmon and K. Howard]

\begin{tabular}{|c|c|c|c|c|c|c|}
\hline $\begin{array}{l}\text { Interval } \\
\text { Number }\end{array}$ & $\begin{array}{l}\text { Interval } \\
\text { Thickness }(\mathrm{cm})\end{array}$ & $\begin{array}{c}\text { Cumulative } \\
\text { Thickness } \\
(\mathrm{m})\end{array}$ & $\begin{array}{c}\text { Relative } \\
\text { Resistance to } \\
\text { Erosion }^{2}\end{array}$ & $\begin{array}{l}\text { Alphabetic } \\
\text { Interval }^{3}\end{array}$ & $\begin{array}{l}\text { Elevation of Top of } \\
\text { Interval } \\
(\mathbf{m})^{4}\end{array}$ & Description \\
\hline 18 & 89 & 8.04 & 1 & $\mathrm{E}$ & 204.3 & $\begin{array}{l}\text { Coarse sand; sorting increases upward from pebbly sand to sand; horizontally } \\
\text { laminate; grains rounded and angular; base is gradational. }\end{array}$ \\
\hline 17 & 34 & 7.15 & 4 & D & 203.5 & $\begin{array}{l}\text { Angular gravel of locally derived clasts (sidestream deposit); pebbles to } \\
\text { granules; poorly sorted; sharp base. }\end{array}$ \\
\hline \multicolumn{7}{|c|}{ Mud facies } \\
\hline 16 & 31 & 6.81 & 4 & C & 203.1 & $\begin{array}{l}\text { Medium to fine sand, fining upward; planar laminations; minor soft-sediment } \\
\text { folding. Upper contact is erosional. }\end{array}$ \\
\hline 15 & 38 & 6.5 & 4 & C & 202.8 & $\begin{array}{l}\text { Medium sand; fines upward; planar laminations and minor ripple crossbedding; } \\
\text { 1-cm-thick mud cap. }\end{array}$ \\
\hline 14 & 14 & 6.12 & 4 & C & 202.4 & Fine sand; crossbedded with 1-cm-amplitude ripples. \\
\hline 13 & 20 & 5.98 & 4 & C & 202.3 & Silty fine sand, finely laminated, planar, horizontal. \\
\hline 12 & 32 & 5.78 & 4 & C & 202.1 & $\begin{array}{l}\text { Poorly consolidated sand, crossbedded; sets as much as } 15 \mathrm{~cm} \text { thick; dips to } \\
30^{\circ} \text {, are concave-up, and are tangential at base. }\end{array}$ \\
\hline 11 & 16 & 5.46 & 4 & C & 201.8 & $\begin{array}{l}\text { Same as underlying interval: upward fning medium sand to silty fine sand; } \\
\text { uppermost } 5 \mathrm{~cm} \text { is silty fine sand. }\end{array}$ \\
\hline 10 & 5 & 5.3 & 4 & C & 201.6 & $\begin{array}{l}\text { Upward-fining medium sand to silty fine sand; } 90 \% \text { is ripple crossbedded; top } \\
10 \% \text { is silty fine sand cap. }\end{array}$ \\
\hline 9 & 11 & 5.25 & 4 & C & 201.6 & Massive fine sand with on or two rust colored, subvertical root stains. \\
\hline 8 & 26 & 5.14 & 4 & $\mathrm{C}$ & 201.4 & Massive fine sand; 5 - to $10-\mathrm{cm}$ thick beds; subtle lamination; rusty zones. \\
\hline 7 & 13 & 4.88 & 4 & C & 201.2 & Silty fine sand; 1 -cm-amplitude ripple crossbedding. \\
\hline 6 & 24 & 4.75 & 4 & C & 201.1 & $\begin{array}{l}\text { Medium to fine sand in } 10 \mathrm{~cm} \text { layers that fine upward; two clay layers } 2 \text { to } 3 \\
\mathrm{~cm} \text { thick. }\end{array}$ \\
\hline 5 & 16 & 4.51 & 4 & C & 200.8 & $\begin{array}{l}\text { Medium to fine sand bed; fines upward. } \\
\text { Four to five upward-fining beds, } 80 \text { to } 85 \% \text { of total thickness is fine sand with }\end{array}$ \\
\hline 4 & 70 & 4.35 & 4 & C & 200.7 & $\begin{array}{l}\text { ripple crossbedding ( } 1 \text { to } 5 \mathrm{~cm} \text { amplitude); Mud cap on each bed; beds are } 5-35 \\
\mathrm{~cm} \text { thick; minor soft-sediment deformation of mud parts. }\end{array}$ \\
\hline 3 & 135 & 3.65 & 4 & C & 200.0 & $\begin{array}{l}\text { Beds } 5 \text { to } 50 \mathrm{~cm} \text { thick of upward-fining, ripple-crossbedded fine sand grading } \\
\text { up to mud; mud caps are discontinuous and of variable thickness } 1 \text { to } 5 \mathrm{~cm} \text {; } \\
\text { approximately } 80 \text { to } 85 \% \text { of thickness is fine sand. Photograph in fig. } 10 \mathrm{C} \\
\text { shows this interval. }\end{array}$ \\
\hline 2 & 30 & 2.3 & 3 & B & 198.6 & $\begin{array}{l}\text { Gypsiferous mud beds, finely laminated horizontally in two or more silty parts; } \\
\text { mud (mostly clay) dominates. }\end{array}$ \\
\hline 1 & 200 & 2 & 3 & A & $\begin{array}{l}198.3 \\
196.3\end{array}$ & $\begin{array}{l}\text { Covered interval of mud and sand. } \\
\text { Lake elevation at base of exposed section. }\end{array}$ \\
\hline
\end{tabular}

${ }^{1}$ GPS data for points measured at the top of reference section (explained in appendix 1) and elevation of Lake Mohave in April-May 2007.

${ }^{2}$ Relative resistance estimated on subjective scale from 0 to 6 , with 6 being most resistant (vertical).

3 Alphabetic assignment corresponding to the summary reference section in figure 25.

${ }^{4}$ Elevation computed by adding cumulative measured thickness to the GPS-measured elevation at base of section. The $0.9 \mathrm{~m}$ discrepancy between value at the top of exposure and the GPS elevation at

07-424-4 is due to the combination of GPS error and vertical outcrop measurement error. 
This page intentionally left blank. 
Produced in the Menlo Park Publishing Service Center, California Manuscript approved for publication, October 11, 2011

Text edited by James W. Hendley II

Layout and design by Stephen L. Scott 


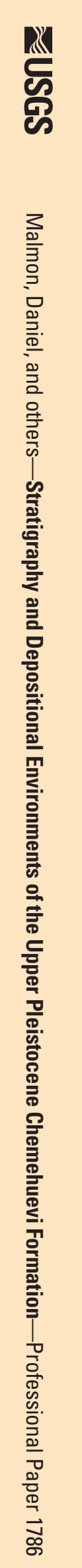

